Economic Imperatives for Women's Writing in Early Modern Europe 


\title{
Women Writers in History
}

\author{
Editorial Board \\ Nadezhda Alexandrova (Sofia University, Bulgaria) \\ Hilde Hoogenboom (Arizona State University, USA) \\ Amelia Sanz (Complutense University of Madrid, Spain) \\ Suzan van Dijk (Huygens ING, Amsterdam, Netherlands) \\ Ton van Kalmthout (Huygens ING, Amsterdam, Netherlands) \\ Kerstin Wiedemann (Université de Lorraine, Nancy, France)

\section{Advisory Board} \\ Vanda Anastacio (Universidade de Lisboa, Lisbon, Portugal) \\ Viola Parente-Čapková (University of Turku, Finland) \\ Marie-Louise Coolahan (NUI Galway, Ireland) \\ Biljana Dojcinovic (Belgrade University, Serbia) \\ Ramona Mihaila (Spiru Haret University, Bucharest, Romania) \\ Katja Mihurko Poniz (Univerza v Nova Gorica, Slovenia) \\ Henriette Partzsch (University of St. Andrews, UK) \\ Marie Nedregotten Sørbø (Volda University College, Norway)
}

VOLUME 2

The titles published in this series are listed at brill.com/wwih 


\section{Economic Imperatives for Women's Writing in Early Modern Europe}

Edited by

Carme Font Paz and Nina Geerdink

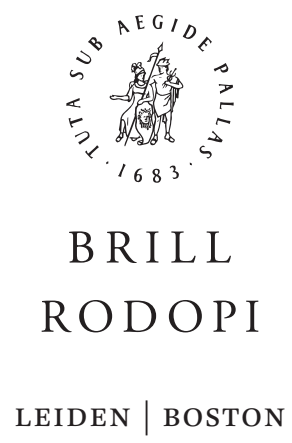


This is an open access title distributed under the terms of the CC BY-NC-ND 4.0 license, which permits any non-commercial use, distribution, and reproduction in any medium, provided no alterations are made and the original author(s) and source are credited. Further information and the complete license text can be found at https://creativecommons.org/licenses/by-nc-nd/4.0/

The terms of the cc license apply only to the original material. The use of material from other sources (indicated by a reference) such as diagrams, illustrations, photos and text samples may require further permission from the respective copyright holder.

An electronic version of this book is freely available, thanks to the support of libraries working with Knowledge Unlatched. More information about the initiative can be found at www. knowledgeunlatched.org.

Cover illustrations: Top: Portrait of Amelia Bassano Lanier by Nicholas Hilliard (1547-1619). Public domain, Wikimedia Commons, The Yorck Project; Middle: Portrait of Dorothe, 1682. Online resources of The Norwegian National Library, "Image - Norske forfatterportretter fra kobberstikk til silverprints': http://www .nb.no/Presse/For- presse/Pressebilder/IMAGE-Norske-forfatterportretter-fra-kobberstikk-til-silverprints; Bottom: Isabelle de Charriere. Bust in plaster by Jean- Antoine Houdon, 1771. Bibliotheque publique et universitaire, Neuchâtel.

The Library of Congress Cataloging-in-Publication Data is available online at http://catalog.loc.gov LC record available at http://lccn.loc.gov/2018037007

Typeface for the Latin, Greek, and Cyrillic scripts: “Brill”. See and download: brill.com/brill-typeface.

ISSN 2352-8354

ISBN 978-90-04-38299-2 (hardback)

ISBN 978-90-04-38302-9 (e-book)

Copyright 2018 by Carme Font Paz and Nina Geerdink. Published by Koninklijke Brill NV, Leiden, The Netherlands.

Koninklijke Brill NV incorporates the imprints Brill, Brill Hes \& De Graaf, Brill Nijhoff, Brill Rodopi, Brill Sense, Hotei Publishing, mentis Verlag, Verlag Ferdinand Schöningh and Wilhelm Fink Verlag. Koninklijke Brill NV reserves the right to protect this publication against unauthorized use.

This book is printed on acid-free paper and produced in a sustainable manner. 


\section{Contents}

Acknowledgements VII

Notes on Contributors VIII

1 Introduction: Women, Professionalisation, and Patronage 1 Carme Font Paz and Nina Geerdink

2 Women Authors' Reputation and Its Relationship to Money

Earned: Some Early French Writers as Examples $\quad 16$ Suzan van Dijk

3 Words for Sale: Early Modern Spanish Women's Literary Economy 40 Nieves Baranda

$4 \quad$ Fighting for Her Profession: Dorothe Engelbretsdatter's Discourse of Self-Defence 73

Marie Nedregotten Sørbø

$5 \quad$ Writing for Patronage or Patronage for Writing? Two Case Studies in Seventeenth-Century and Post-Restoration Women's Poetry in Britain 97

Carme Font Paz

6 Possibilities of Patronage: The Dutch Poet Elisabeth Hoofman and Her German Patrons 124

Nina Geerdink

7 Between Patronage and Professional Writing. The Situation of Eighteenth Century Women of Letters in Venice: The Example of Luisa Bergalli Gozzi $\quad 147$

Rotraudvon Kulessa

8 From Queen's Librarian to Voice of the Neapolitan Republic: Eleonora de Fonseca Pimentel 167

Irene Zanini-Cordi 
9 “[S]ome employment in the translating Way": Economic Imperatives in Charlotte Lennox's Career as a Translator 192 Marianna D'Ezio

10 Beating the Odds: Sophie Albrecht (1756-1840), a Successful Woman Writer and Publisher in Eighteenth-Century Germany 221 Berit C.R. Royer

Index $\quad 257$ 


\section{Acknowledgements}

This volume has been long in the making. In 2012 we organized, together with Suzan van Dijk and Marie Nedregotten Sørbø, a panel about economic imperatives for early modern women's writing at the 2oth Annual sHARP Conference in Dublin (June 26-29), 'The Battle for Books'. The confrontation of English, Dutch and Norwegian cases was so inspiring we decided to enlarge our comparative scope and put together a volume with cases from more European countries. Many colleagues were willing to contribute and we would like to thank them for that, as well as for their cooperation and patience during the process of finalizing the volume. Most of all, we would like to thank the continuous support of Suzan van Dijk, who not only contributed a chapter, but she was always willing to be a helping hand with practical matters, both as a leader of (the now DARIAH Working Group) Women Writers in History and as a member of the editorial board of the series Women Writers in History, of which our book is the second volume. We would also like to thank the rest of the editorial board, especially Nadezhda Alexandrova, as well as the two anonymous peerreviewers whose comments have been very valuable. We thank Alie Lassche for helping us with the index. Since we were working with contributors from all over Europe whose native language was not English, linguistical editing was of major importance. We would like to thank Victoria McIntyre and Francesca Scott for their help in the final phase. Last but not least we would like to thank the publisher, especially Christa Stevens, for being always quick in answering our questions and her engagement in making this volume a reality.

Carme Font Paz and Nina Geerdink

April 2018 


\title{
Notes on Contributors
}

\author{
Suzan van Dijk
}

is a senior researcher at Huygens Institute for the History of the Netherlands (KNAW, Amsterdam). She studied French and comparative literature at universities of Utrecht and Paris-IV, and defended her thesis 1988 at Nijmegen University: Traces de femmes: présence féminine dans le journalisme français du XVIIIe siècle. She continued her research in 18th- and 19th-century women's writing and (transnational) reception, and took the initiative, some 15 years ago, for creating around an on-line database New approaches to European Women's Writing (NEWW) an international network, which is now a DARIAH Working Group entitled Women Writers in History. She published widely in this field, and edited, with Madeleine van Strien-Chardonneau, the Belle de Zuylen Papers/Cahiers Isabelle de Charrière (2006-2015).

\section{Nieves Baranda}

is an expert in Medieval and Early Modern Spanish women writers, full Professor in the Universidad Nacional de Educación a Distancia (UNED), in Madrid, and in 2012-18 Manager for the evaluation of Humanities Research Projects for the national Spanish Ministry of Economy and Competitiviness in the Philology and Philosophy areas. Leader of the Research project BIESES, since 2004 (http://www.uned.es/bieses). This is a digital humanities project on Spanish women writers until 1800 that includes a data base with over 12.000 items, women writer's TEI-XML tagged paratexts and a new section on network analysis and visualizations. Among many other publications she has coedited with Anne J. Cruz The Routledge Research Companion to Early Modern Spanish Women Writers, 2018. Other publications can be found in the BIESES website.

\section{Marie Nedregotten Sørbø}

is Professor of English Literature at Volda University College, Norway, where she has also served as Vice Rector for four years. Her two monographs are Irony and Idyll: Jane Austen's Pride and Prejudice and Mansfield Park on Screen (2014) and Jane Austen Speaks Norwegian: The Challenges of Literary Translation (2018). She has contributed chapters on Jane Austen and George Eliot in Norway to the series The Reception of British and Irish Authors in Europe. She was the Principal Investigator for Norway in the collaborative research project HERA Travelling TexTs 1790-1914. Among her most recent publications are "Elusive Women Writers in Norwegian Nineteenth-Century Reading Societies" (in 
NORA, 2017), and "Travelling Books: When Dorothe Engelbretsdatter Went to America" (in European Journal of Scandinavian Studies, 2017).

\section{Carme Font Paz}

is lecturer in English literature at Universitat Autònoma de Barcelona, Spain. She is also Research Associate at the Center for Medieval and Renaissance Studies at UCLA. She is a specialist in British literature of the long seventeenth century, in particular women's prophetic writing. Her latest book is Women's Prophetic Writings in Seventeenth-Century Britain (Routledge, 2017). Postdoctoral grants at UCLA and Harvard widened her focus to include women's intellectual history, reception, and socio-economic considerations in early modern textualities. She is now preparing a translation, edition and anthology of early modern women's British poetry in Spanish (Cátedra). She has published articles and book chapters on Elizabethan prophecy and poetry, seventeenthcentury women's prose, and eighteenth-century manuscript poetry.

\section{Nina Geerdink}

is assistant professor Early Modern Dutch Literature at Utrecht University, the Netherlands. She is a specialist in Dutch literature from the long seventeenthcentury with research interests in occasional poetry, authorship, and women's writing. She has published articles and book chapters on these and related topics. Her dissertation was published in Dutch:Dichters en verdiensten. De sociale verankering van het dichterschap van Jan Vos (1610-1667) (2012). In her current research project Poets and Profits. A new History of Dutch Literary Authorship 1550-1750 (funded by Nwo, the Dutch Organization for Scientific Research), she analyses the interaction between patronage and professionalism in the discourse about and practice of profitable authorship.

\section{Rotraud von Kulessa}

is full professor for French and Italian Literature at the University of Augsburg (Germany). She has mainly worked about women's writing in French and Italian 18th century and on the position of women writers in the literary field of the Belle Epoque in France and in Italy and Italian Renaissance women writers. She co-directs the ANR/DFG Project EDUlum: Educatrices des Lumières. Le cas de Marie Leprince de Beaumont. Relevant publications: Critical edition of Françoise de Graffigny: Lettres d'une Péruvienne (2014/2016); Entre la reconnaissance et l'exclusion. La position de l'autrice dans le champ littéraire en France et en Italie à l'Epoque 1900 (2011); with Daria Perocco, Laura Terracina. Discorso sopra il principio di tutti i canti d'Orlando Furioso (2017); « Elisabetta Caminer Turra (1751-1796) e L'Europa letteraria: alcune riflessioni sulla traduzione » (2015). 


\section{Irene Zanini-Cordi}

is Associate Professor of Italian Studies at Florida State University. Her areas of specialization are Critical Theory, women's writing, 18th- century and contemporary Italian literature. She is the author of the book Donne sciolte. Abbandono ed identità femminile nella letteratura italiana (2008) and she has published several articles on women writers, Venetian culture and letter writing. Professor Zanini-Cordi is currently completing two book manuscripts. The first focuses on the writings of women who animated Italian salons (1780s-186os) and their influence on the conception and birth of the Italian Nation, while the second is an edited translation of the autobiographies of two 18th-century Italian poet improvisers, Angela Veronese and Teresa Bandettini.

\section{Marianna D'Ezio}

completed a PhD in English Literature at the University of Rome "Sapienza". She teaches as an Adjunct Professor of English at UNINT University for International Studies in Rome and at Marymount International College. Her research interests focus on eighteenth-century women's writing. She edited a collection of essays on eighteenth-century literature (Literary and Cultural Intersections during the Long Eighteenth Century, 20o9), followed by a monograph on British writer Hester Lynch Piozzi (A Taste for Eccentricity, 2010). Her next volume, currently in preparation, deals with the relationships between British women travelers and Italian salonnières in the age of the Grand Tour. She also works as a free-lance translator of classics (Jane Eyre, Dracula, Sense and Sensibility, Testament of Youth, Camilla).

\section{Berit C.R. Royer}

German-American literary specialist. Her area of expertise is late Eighteenth Century Women's literature: She published the dissertation Sophie Albrecht im Kreis der Schriftstellerinnen um 1800 (1999) about the German writer and actress Sophie Albrecht (1756-180o), edited two volumes of her poetry Bunte Kinder schwarzer Nacht (1997) and Vorwärts, vorwärts sehn ich mich (2001). She additionally contributed on the poet to the volume Aufklärung in der Dalbergzeit (2006), and to Verehrt. Verflucht. Vergessen. (2015). She has been working as a translator, as well as lecturer for German and English at San Francisco State University, University of California, San Francisco City College, UsA, and at Hamburg University of Technology in Germany. 


\title{
Introduction: Women, Professionalisation, and Patronage
}

\author{
Carme Font Paz and Nina Geerdink
}

The study of women's writing has become a lively field that has contributed and given rise to many new directions in the broader field of literary studies. Some of these, most importantly the 'material turn', have fuelled the theme of this volume: economic imperatives for women's writing. In the past three decades, with the greater availability of public records and archival materials, literary historians have tended to consider material aspects in their literary analyses and, as such, their collaboration with book historians has increased. Topics such as patronage and professionalism have burgeoned and moneymaking has been put on the agenda as an important factor within the literary field.

Material culture has contributed an invaluable framework for analysing a wealth of data regarding women's lives and works. The material turn was conceived in part as a scholarly interest in any aspect related to the business of writing that affected women's authorship and, thereby, scholars of women's literature have invoked it in many ways to enrich the scope of their inquiries. Nevertheless, the theme of moneymaking did not especially fit within this material subdomain. ${ }^{1}$ The socially inferior position of women and the rhetoric of modesty in their writing led to a predominant focus on social rather than economic imperatives for women's writing. This blind spot affects scholarship about women's writing across the European continent, although the focus on the production and consumption of women's literature in material terms has led to the identification and study of many English professional women writers from the eighteenth century. With regard to economic imperatives for women's writing, two important facts have often been disregarded or overlooked. These animate the purpose of this work: that women's socially inferior position was not a decisive limiting factor in their creative and professional

1 See for an overview of the connections between the study of women's writings and the material turn, Material Cultures of Early Modern Women's Writing, eds Patricia Pender and Rosalind Smith, Basingstoke 2014. See also Gillian Wright, Producing Women's Poetry. Text and Paratext, Manuscript and Print, Cambridge 2013. 
endeavours, and that economic professionalisation coexisted with patronage and was not, in many cases, incompatible with it.

For some decades now, scholars of culture have been aware that women in the book trade were neither scarce nor passive. Of the more than 300 English women identified as connected with the trade between 1557 and 1700, there may well have been some whose interest in the business was minimal and whose participation was therefore limited, but the everyday partnership of husband and wife in, for example, dividing responsibilities for shop keeping or in the supervision of apprentices is well-documented. ${ }^{2}$ Women could also own and run their own businesses, often after their husbands or fathers had died. Women are found to have been printing as well as bookselling and publishing, organising the distribution of newspapers as mercury women and hawking papers and pamphlets on the streets. This was an accepted practice in large parts of Europe. ${ }^{3}$

The background and activities of female authors in the sixteenth and seventeenth centuries appear to be less diversified. Women writers were most often from wealthy families. This is not only the case because of their education, but also because writing in this period was expensive in many ways. The opportunity to profit from writing grew, though, during the seventeenth and eighteenth centuries, even though as with their male peer writers, income from writing was rarely sustained. In this period, the number of women writers increased while their backgrounds varied more and more. According to Elaine Hobby, some 400 British women wrote between 1640 and 1700, and over one-half of these writers produced tracts of a religious and political nature. ${ }^{4}$ Stanton adds to this data saying that "the numbers of women starting to write, decade by decade,

2 The Cambridge History of the Book in Britain, 1557-1695, Cambridge 2008, vol. IV, 440-41.

3 See about women in the early modern book trade in Europe G. Sheridan, "Women in the Book Trade in the 18th Century: An Untold Story", in Writing the History of Women's Writing. Toward an International Approach eds Suzan van Dijk et al, Amsterdam 2001, 197-210; specifically, for England: The Cambridge History of the Book, Maureen Bell, "Women in the English Book Trade 1557-170o", Leipziger Jahrbuch zur Buchgeschichte, 6 (1996), 13-46 and Tamara Hunt, "Women's Participation in the Eighteenth-Century English Publishing Trades", LeipzigerJahrbuch zur Buchgeschichte 6 (1996), 47-66; for Germany: Mark Lehmstedt, "'Ich bin nun vollends zur Kaufmannsfrau verdorben'. Zur Rolle der Frau in der Geschichte des Buchwesens am Beispiel von Friederike Helene Unger (1751-1813)", Leipziger Jahrbuch zur Buchgeschichte 6 (1996), 81-154; for France: G. Sheridan, "Women in the booktrade in eighteenth-century France", British Journal for Eighteenth-Century Studies 15 (1992), 52-69; for Italy: D. Parker, "Women in the Book Trade in Italy, 1475-162o", Renaissance Quarterly 49/3 (1996), 509-41; and for the Dutch Republic: Paul Hoftijzer, "Women in the Early Modern Dutch Book Trade", in Writing the History of Women's Writing eds Suzan van Dijk et al, 211-22.

4 Elaine Hobby, Virtue of Necessity: English Women's Writing 1649-88, London 1988, 27. 
increased steadily but slowly from the 1660 os to the 1730 s. $^{5}$ For other European countries, a relatively comparable increase has been noted, particularly in France, but also in Spain, Italy and the Dutch Republic. ${ }^{6}$ The early decades of the eighteenth century are marked in some countries by "a new cultural power for women" as part of the consolidation of middle-class hegemony, ${ }^{7}$ in which many women made their living by their pen, which meant that they earned money from the books they published, but most often from their freelance work (or hackwriting) in the buoyant press or the theatre. In some cases, such as in Britain, women's presence in the writing market was so normalised that they became invisible as authors, a "nobody story" of individuals whose authorship had transformed into a commodity and, therefore, a "vanishing act". ${ }^{8}$ As we shall see, professionalisation of writing, and the recognition of women as authors with an audience, was not incompatible with the practice of patronage in many instances. E.J. Clery defines this scenario for the second half of the eighteenth century as a slight and gradual "modification of the patronage system, involving an admission of need and dependency, and with an even greater degree of selfadvertisement and public exposure". ${ }^{9}$ In both models, the success of their work depended on readers' satisfaction, social impact or sales. However, often the professional model implied that the audience was broader and more diversified.

With the historical intersection of increasing possibilities to profit for a larger number of women writers as a starting point, this volume adds a chapter to the history of profitable writing in the early modern period.

\section{Economic Imperatives in the Literary Field}

The history of the professionalisation of the literary field in Europe needs further scholarly attention and requires a comparatist approach. The large

5 Judith P. Stanton, "Statistical Profile of Women Writing in English from 1660 to 180o", in EighteenthCentury Women and the Arts eds Frederick Keener and Susan Lorsch, New York 1988, 251.

6 Cf. for the Dutch Republic, Women's Writing from the Low Countries 1200-1875/A Bilingual Anthology, eds Lia van Gemert et al, Amsterdam 2010, 64. Cf. for the Spanish case, The Routledge Research Companion to Early Modern Spanish Women Writers, eds Nieves Baranda and Anne J. Cruz, New York 2017, 1-12. Cf. for the French case, A History of Women's Writing in France, ed. Sonya Stephens, Cambridge 20oo. Cf. for the Italian case, Letizia Panizza, A History of Women's Writing in Italy, Cambridge 2001.

7 Cf. Nancy Armstrong, Desire and Domestic Fiction. A Political History of the Novel, Oxford 1987; Jane Spencer, The Rise of the Woman Novelist, Oxford 1986.

8 Cf. Catherine Gallagher, Nobody's Story: The Vanishing Acts of Women Writers in the Marketplace $1670-1820,1994$.

9 E.J. Clery et al, Authorship, Commerce and the Public: Scenes of Writing, 1750-1850, London 2002. 
number of studies into professionalisation in early modern England and comparatively fewer studies about other national traditions show differences in dates and details but share a remarkable teleological line that can no longer be taken for granted. The narrative of the professionalisation of the literary field that prevailed for so long suggested that money at first did not play a role in literary authorship and only really became a dominant factor in the nineteenth century. ${ }^{10}$ The emergence of literature written for a general public was, in this view, connected to the rise of the market. Debates surrounding the topic claimed that, in the sixteenth and seventeenth centuries, authors were dependent on patronage and on a balance between writer-patron that was not always meant to make the author's living, but to procure social or political advantage: writers often occupied a position to earn their daily bread or they were from rich descent. For most countries, the traditional narrative suggested that the patronage system during the eighteenth century was replaced by a commercial system in which authors saw more and more possibilities to make a living out of writing - although they often still needed to do side-jobs, such as editing, translating and lecturing. Moreover, writing as a profession still remained unacceptable among the literary elite for most of the century. In this view, literary writing only became a real 'profession' in the nineteenth century, with authors able to work independently from patrons, church and state. Authors were now in a paradoxical situation in which they used the market to make money with their writings even though many struggled with commercial success or lack of it, while simultaneously and continuously demonstrating their independence from this market.

The traditional narrative is an idealisation in itself, as really living from literary writing is still a difficult feat for the happy few. Moreover, the tension between literature and the market still exists today and existed prior to the nineteenth century. In present times, literary writers often have difficulties making a living - unless they are a bestselling author, like E.L. James and Dan Brown and, as a bestselling author, writers are frequently forced to defend themselves against accusations of commerciality. Bestselling authors are still often criticised as not being 'real' literary authors and of producing pulp instead of real

10 This narrative is referred to by, among others, Dustin Griffin, Authorship in the long Eighteenth Century, Newark 2014, esp. 171-185; M. Rose, "The Author as Proprietor", Representations 23 (1988), 51-85; M. Woodmansee, "The Genius and the Copyright: Economic and Legal Conditions of the Emergence of the Author", Eighteenth Century Studies 17/4 (1984), 425-28; Alain Viala, Naissance de l'écrivain. Sociologie de la littérature à l'âge classique, Paris 1985; Gerard Bouwmeester, Nina Geerdink and Laurens Ham, "Een veelstemmig verhaal. Auteurschap in de Geschiedenis van de Nederlandse literatuur", Nederlandse letterkunde 20/3 (2015), 215-36. 
Literature. Therefore, no aspect of this complex relationship between money and literature is really new. Indeed, even during the Renaissance, writers were occupied with framing their work and that of others in relation to money, for example, by assuring readers of their independence and sincere reasons for writing, by complaining about a lack of possibilities of patronage, or by criticizing hack writers. This shows in fact that money played an important role in the literary field, long before 1800 .

During the last three decades, scholars have begun to discuss the history of the professionalisation of the literary field in a critical manner, and to ask whether the teleological narrative does justice to the dynamics of developments related to money. Patronage has much in common with the literary market, both in its systematics and in its relationship to money: patronage was often more related to an author's daily bread than has been assumed by seventeenth-century authors themselves and by scholars analysing their work some decades ago. ${ }^{11}$ Moreover, as early as the sixteenth century, there were poets relying less on patronage and on circulating their writings (as opposed to printing them). They must be regarded as professional authors or at least as authors who discussed the possibilities granted by commercial authorship. ${ }^{12}$ Geoffrey Turnovsky's contention that the transition from patronage to market was not a fundamental break, but a natural process in which more exteriorities than intellectual values were replaced also fits in, as does Dustin Griffin's argument about the coexistence of a system of patronage and of commerce during the long eighteenth century. ${ }^{13}$ Voices like these reemphasise the significance of research and debate on the dynamics and importance of moneymaking for pre-18oo literary authors.

The period between 1650 and 1800 is still commonly acknowledged as one in which the commercial literary marketplace and a culture of professional authorship emerged. Indeed, larger numbers of writers (poets, playwrights, satirists and novelists) participated in a growing field of commercial exchange in which the main commodity was intellectual and creative capital. Several

11 Helen Smith, Grossly Material Things. Women and Book Production in Early Modern England, Oxford 2012; Andrew Pettegree, The Book in the Renaissance, New Haven 2010, 16166; Nina Geerdink, Dichters en verdiensten. De sociale verankering van het dichterschap van Jan Vos (1610-1667), Hilversum 2012.

12 Laurie Ellinghausen, Labor and Writing in Early Modern England, 1567-1667, Aldershot/ Burlington 2008; Joseph Loewenstein, "Wither and Professional Work", in Print, Manuscript and Performance eds A.F. Marotti and M.D. Bristol, Columbus $\mathrm{OH}$ 200o; Sarah Prescott, Women, Authorship and Literary Culture, 1690-1740, Houndmills/New York 2003.

13 Geoffrey Turnovsky, The Literary Market. Authorship and Modernity in Old Regime France, Philadelphia 2010; Griffin, Authorship. 
scholars have sought to define the exercise of authorship in this transitional phase between medieval and Renaissance concepts of autoritas as agency and authorship in Romantic terms. Mark Rose and Alvin Kernan, for instance, discussed the modernity of early eighteenth-century literary culture (as opposed to the celebrated birth of the modern talented author in the advent of Romanticism).${ }^{14}$ According to Kernan, the new literary marketplace freed "the writer from the need for patronage and the consequent subservience to wealth [...] through a copyright law that made the writer owner of his own writing." ${ }^{15}$ This was a major shift, but one which, for Dustin Griffin and Margaret Ezell, was not a determining factor to significantly change authorial practices and contexts of production. ${ }^{16}$ As we have seen, and as this book contends, manuscript culture, patronage systems and leisure writing coexisted and coalesced in a growing commercial market that was transforming literary output - not only journalistic or informative writing - into a commodity that was more subject to rules of supply and demand.

To use a Foucauldian term, the concept of what or who was an author was also modified along with its sphere of influence. We cannot refer to the professionalisation of authorship at a time in which the notion of 'genius' or individual talent was hardly taken into account as a distinctive trait. Writing as an artistic expression was a social act, often linked to the taste and political expectation of its intended audience (patrons, sectarian groups, or reduced audiences which read in a culture of manuscript circulation) rather than to notions of originality and aesthetic quality. The emergence of a commercial market did not change the imperatives of having to 'satisfy' a growing and diverse audience in order to succeed as a writer. At the same time, more possibilities to achieve public exposure in more impersonal terms existed.

\section{Economic Imperatives for Women's Writing}

This volume seeks to contribute discussions about patronage, professionalism, authorial reputations and economic imperatives from the perspective of early modern women's writing in Europe. It will do so by opening up the research into economic imperatives for women's writing in two ways: by adding a

\footnotetext{
14 Alvin Kernan, Samuel Johnson and the Impact of Print, Princeton 1989; Mark Rose, Authors and Owners: The Invention of Copyright, Cambridge 1993.

15 Kernan, Samuel Johnson, 5.

16 Margaret Ezell, Social Authorship and the Advent of Print, Baltimore 1999; Griffin, Authorship.
} 
comparative European perspective, and - taking the discussions about professionalism and patronage as a starting point - by enlarging the group of women writers for whom the perspective of economic imperatives is relevant.

In literary histories of most single European countries, the field of economic imperatives for women's writing in the seventeenth and eighteenth centuries has been neglected. Whereas money, as a consequence of the dominance of the traditional narrative in the historiographies of many literatures, is said to play a minor role in the literary production before 1700, and a role that was growing, but not dominant until 180o, the importance of money for female authorship seems to have been underestimated even more. The only country whose women writers have been thoroughly studied from the perspective of moneymaking is England. A case in point is the work of the sixteenth-century author Isabella Whitney (1567-1573), who represented herself as a maidservant writing in need of money. Her work has been tackled as an exception and scholars have tried to explain her extraordinary self-representation in terms of networking. In 2005, Laurie Ellinghausen was the first to interpret it as part of a professional authorship. ${ }^{17}$ Cases such as Whitney's are scarce in the sixteenth century, but from the late seventeenth century onwards the number of professional women writers rises and so does the amount of studies into their authorship. ${ }^{18}$

The insights stemming from research into English women writers and their relationship with money have not yet radically changed literary historical perspectives on women's writing in other European countries, nor stimulated comparative research into female professional authorship. ${ }^{19}$ In some European countries, research into women's writing is still in its exploratory phase. In many literary histories of the early modern period, women writers remain the exceptions. In countries where this has changed over the last decades, research into now well-known women writers needs to be elaborated on, particularly with regard to where economic imperatives presumably play a role. This is

17 Laurie Ellinghausen, "Literary Property and the Single Woman in Isabella Whitney's $A$ Sweet Nosgay", Studies in English Literature 1500-1900 45 (2005), 1-22; Ellinghausen, Labor and Writing.

18 Cheryl Turner, Living by the Pen. Women Writers in the Eighteenth Century, New York/London 1992; Paula McDowell, The Women of Grub Street: Press, Politics, and Gender in the London Literary Marketplace, 1678-1730, Oxford 1998; Betty Schellenberg, The Professionalization of Women Writers in Eighteenth-Century Britain, Cambridge 2005.

19 This is due to a general lack of in-depth comparative studies regarding women's literature, as is signalled by Martine van Elk in Early Modern Women's Writing. Domesticity, Privacy, and the Public Sphere in England and the Dutch Republic, Cham 2017, which itself is an example of such a study. 
not easy, since women's position within literary histories blurs their routes to professional authorship and other forms of engagement with financial gain. This means that the idea of economic imperatives for women's writing is often covered by the way in which women writers have entered literary histories.

Female authorship has been treated as a different 'category' from canonical or even male authorship. The focus on the literary history of female authorship has been on restrictions rather than on possibilities. ${ }^{20}$ Women writers, who traversed the boundaries of the private sphere they were bound to, were exceptions, and the active and growing participation of women writers in the literary field was something new during the early modern period. Therefore, the conditions and difficulties of women's entrance in the literary field have been highlighted in scholarly analysis, supposing that being accepted there as a woman was something to be grateful for instead of a position that, once earned, could be used for earning.

At least two defining characteristics of early modern women's writers and their texts have contributed to a blurred view of their economic imperatives. Firstly, female authors were often women from the elite. In any case, up to the eighteenth century, a literary author required some formal or informal education. These women thus often came from wealthy families and did not need to earn anything from their writings. What is often omitted, however, is that women writers from lower classes also wrote, such as the British Mary Leapor $(1722-1746)$, as we shall see in this volume. In the English case, a 'shifted critical lens' revealed that many female authors were from the lower classes. ${ }^{21}$ Moreover, women descending from wealthy families sometimes became poverty stricken, as many case studies in this volume will show.

Secondly, the study of women's writing is often confined to their private circles in keeping with the early modern moral that excluded public functions for women. Kim Walker cleverly summarises this with her contention: 'If writing for a public audience could be interpreted as unchaste, then writing for financial gain could be read as a form of prostitution. ${ }^{22}$ Women often justified their writings by representing them as a dutiful fulfilment of their free time, as opposed to labour for financial gain, and therefore deflecting attention by fulfilling societal, male expectations in their self-representation. ${ }^{23}$

\footnotetext{
20 Schellenberg, The Professionalization.

21 McDowell, The Women, 14.

22 Quoted in Ellinghausen, Labor and Writing, 20.

23 Jennie Batchelor, Women's Work: Labour, Gender, Authorship 1750-1830, Manchester/ New York 2012. About women in between private and public spheres see also Van Elk, Early Modern Women's Writing.
} 
Aspects of women's (self-)representation have caused the more extensive Anglo-American scholarship into women's writing to tend to privilege those writers who appeared more openly concerned with profit or their public image as 'respectable females'. Relying on the work of Margaret Ezell, Sarah Prescott makes a distinction between successful professional authors, presenting themselves as such, and the so-called 'genteel amateurs', writing for their own circles and presenting themselves very modestly. ${ }^{24}$ The first category, that of professional authors, was active in public and not as easily overlooked by literary historians as the women writing for their private circle or, at least, presenting themselves as doing so. Models of female authorship that had arisen out of the emphasis on the professional woman writer could be based on a sexualised trope: either the anti-feminist image of the woman writer as a libertine, or as a modest amateur. Kathryn King has called this a "moralized taxonomy" which has haunted women's literary history of this period in particular. ${ }^{25}$ Such labels have also obscured other factors that shaped women's writing, such as political affiliation and religious belief, especially before the $1720{ }^{26}$

Women writers who did not present themselves as professionals, but who did relate to financial gain one way or the other - for example, by being part of relationships of patronage - were certainly numerous and should not be overlooked. There was some money to be made in writing, and many women were attracted to it by economic necessity, whereas others did not have to make a living out of their writing, even though they could receive some occasional payment. Cheryl Turner calls the latter group "dependant professionals", and while they were more prone to hack for bread, it is not at all the case that women who made money out of writing did it out of commissioned work only. ${ }^{27}$

At the same time, some of these women might have been free from economic imperatives, but still could be regarded a professional author. Anna Seward, for example, the "Swan of Lichfield" (1742-1809), enjoyed a successful career as an early and published Romantic poet writing from the countryside and making no mention whatsoever in her correspondence of any financial gain. She was, however, very much concerned about her reputation as a writer beyond her condition as a woman. Together with other women who were neither cosmopolitan nor particularly (or publicly) concerned with financial gain, such as

\footnotetext{
24 Margaret Ezell, Social Authorship and the Advent of Print, Baltimore 1999; Prescott, Women.

25 Kathryn King, "Elizabeth Singer Rowe's Tactical Use of Print and Manuscript", in Women's Writing and the Circulation of Ideas: Manuscript Publication in England, 1550-1800, ed G.L. Justice and N. Tinker, Cambridge 2002, 75 .

26 Hobby, Virtue of Necessity.

27 Turner, Living by the Pen, 6 .
} 
Lady Mary Chudleigh or Elizabeth Singer Rowe in the British scene, the notion of being both an author and a professional one at that might have more to do with women's ability to be published and read on a consistent basis, regardless of whether the token of exchange for this access was economic or otherwise. Some of these women resorted to self-publishing and succeeded as writers with considerable broad audiences.

In other words, did financial gain authorise or diminish the literary standing of authors, whether male or female? Was a self-published author less professional than an author released by a commercial publisher? This is still an unresolved issue that, to our mind, is best approached by considering how women negotiated the economic aspects which they encountered in their particular case, whether these were copyright issues and direct profit, consequences from the gift-sphere of patronage, or a combination of both, how they alternated artistic creation with hacking as translators or journalists, how they managed and effected payment of copyrights or patronage services, or how they managed subscription as an alternative way of generating income and leverage as authors. This book is chiefly concerned with how economic factors impinged on women's literary output and how the realisation that their writing was subject to commercial exchange affected their self-representation as authors.

This representation involved not only the authors themselves, but also many other social agents. The literary marketplace relied on older traditional writing practices to conceptualise the author who went to print. For instance, the periodicals and miscellany writings, two of the most popular, original and eclectic types of publication, were based on manuscript circulation and modes of social authorship associated with coteries. ${ }^{28}$ This would suggest, once again, that manuscript and print cultures were not separate modes of authorship at that time, but that both configured, reflected and regulated the economy of exchange that played out in the literary marketplace. Ultimately, what remains to be ascertained are the ways in which the new reconfiguration of authorship informed the market and its audience, and how these in turn modified the concept of authorship. The figure of the publisher mediated, filtered and decided upon the flow of works that entered public opinion, and this regulation was based on criteria of profitability and impact. Women, as well as men, were made to negotiate their entrance to this flow by marketing and fashioning themselves to their intended audiences. Authors were attached to their publishers, audiences and patrons; agents dually or triangularly related to each other.

28 Margaret J.M. Ezell, “The Gentlemen's Journal and the Commercialization of Restoration Coterie Literary Practices", Modern Philology 89/3 (1992), 323-40. 


\section{The Chapters in This Volume}

The case studies collected in this volume relate to authors working at various moments in the seventeenth and eighteenth centuries, and in different Western European countries. This accounts for changing (pre)conditions for the development of women's writing and women's literary careers. Still, it is possible to derive two general conclusions. What all chapters show is, firstly, that the women writer's financial gain during the whole period and in every country, in some way or the other, was framed as exceptional; and, secondly, that a sharp distinction between patronage and professionalism in connection to financial gain and (self)representation is impossible.

Suzan van Dijk in our opening chapter does not elaborate on one case but shows how the framing of financial gain as exceptional for early modern women writers continued until far into the nineteenth century by analysing biographical works of the eighteenth and nineteenth centuries. It turns out women writer's financial gain needed to be defended by referring either to the woman's role as a benefactor, supporting others with the money earned, or to her poor position, being an appropriate object of charity.

Each of the following chapters present cases of women writers who relate to financial gain. As such being framed as exceptional leads them either to proudly present themselves as professionals, or to veil their economic imperatives and present themselves modestly as amateurs. Examples of the first are the relatively well-known cases of Charlotte Lennox and Sophie Albrecht, both active in the eighteenth century, in England and Germany respectively. From the chapters by Marianna D'Ezio and Berit Royer, it appears that - as a translator (Lennox) and a novelist-publisher (Albrecht) - they profited from the popularity of the genre of the novel in their time, along with the encompassing professionalisation of women's writing that this entailed. This was not the case for the early example of the Danish-Norwegian Dorothé Engelbretsdatter, who was in her own time as proudly successful as any eighteenth-century novelist. In her chapter, Marie Nedregotten Sørbø describes how she was nevertheless overlooked in literary history for a substantial period, therewith showing how being a professional woman writer outside of eighteenth-century England means staying out of the picture of many literary historians. These three women writers obtained benefit not only from their professionalism, but also from being termed as professional writers. In many instances, there was no benefit in such a representation.

Cases of women representing themselves modestly, or not proudly engaging in the commercial book market, form the greater part of this volume. Sometimes, the attempt to earn through literary activity really was a measure of 
emergency, such as in Nina Geerdink's case of the Dutch Elisabeth Hoofman, who early in the eighteenth century refused to publish her works up until the moment she lost her income and she needed to improve her relationship of patronage by publishing some laudatory poems. It is also evident, in Carme Font Paz's case of the English Aemilia Lanyer, who tried to obtain patronage in court circles of the late sixteenth century after her businesses failed. A case in point is the scarcely known British Ann Yerbury writing poetry in the early decades of the eighteenth century, described in the same chapter, who obtained enough of an income separate from her writings and, therefore, did not publish them, nor maintained relationships of patronage on the basis of manuscripts. Moreover, in her chapter on the eighteenth-century Eleonora de Fonseca Pimentel from Naples, Irene Zanini-Cordi analyses how intellectual and ideological imperatives - in the end more important than economic ones - were often overruled by the need to make money.

Eighteenth-century Venice, as the centre of Italian publishing and culture with a long tradition of Renaissance art, is an European locus that shows the shift from patronage to professional writing as being often abusive and hostile for women. Rotraud von Kulessa explores Luisa Bergalli's literary career as a playwright and journalist and examines the pitfalls for individuals, especially women, who gradually moved from patronage to a market economy that did not pay well for their writings and even usurped and abused their authorship, as was the case with Luisa's husband.

A different and more pleasant scenario for women who understood writing as a way of self-expression is depicted by Nieves Baranda, who uses the case studies of Luisa Sigea, Ana Caro, María de Zayas and individual nuns in seventeenth-century Spain to illustrate the rewards and promotion that these women obtained from the court in exchange for their plays, while they also wrote comedies that were successfully sold to publishers.

Economic imperatives thus influenced self-representation and the rhetorical strategies of women writers, as well as their publishing strategies. The entanglement of patronage and professionalism is obvious for example in Baranda's chapter, in which the literary careers of women, at a time when market economies were not fully developed, seemed to make the best of both worlds as they often combined the promotion and reputation that patronage gave them with a more tangible benefit from a vibrant public that consumed and paid for fiction works. Other strategies that emphasize the fragile balance between patronage and professionalism are publishing for the broader market as a precondition for patronage (as is shown in Geerdink's chapter) and using patronage as an alternative for market writing (Font Paz) or the other way around (Von Kulessa). Also in these cases, women were willing to have their writings 
read and even admired, since they often aimed to affect social change that put women at the centre.

To conclude, what the chapters in this volume show is that at a time in which a commercial market emerged while modes of patronage, in connection to this market, altered, women were actors of change and creativity by taking part in and representing themselves in relation to these developments. This volume hopes to encourage further comparative research to show how both the entanglement between patronage and professionalism and women's representation in connection to it took place within the differing contexts of various countries, both within and outside their borders.

\section{Bibliography}

Batchelor, Jennie. 2012. Women's Work: Labour, Gender, Authorship 1750-1830. Manchester/New York: Manchester University Press.

Bell, Maureen. 1996. 'Women in the English Book Trade 1557-1700', in Leipziger Jahrbuch zur Buchgeschichte 6:13-46.

Bouwmeester, Gerard, Nina Geerdink and Laurens Ham. 2015. 'Een veelstemmig verhaal. Auteurschap in de Geschiedenis van de Nederlandse literatuur' in Nederlandse letterkunde 20(3): 215-36.

Clery, E.J., Caroline Franklin and Peter Garside. 2002. Authorship, Commerce and the Public: Scenes of Writing, 1750-1850. London: Palgrave Macmillan.

Elk, Martine van. 2017. Early Modern Women's Writing. Domesticity, Privacy, and the Public Sphere in England and the Dutch Republic. Cham: Springer/Palgrave Macmillan.

Ellinghausen, Laurie. 2005. 'Literary Property and the Single Woman in Isabella Whitney's A Sweet Nosgay' in Studies in English Literature 1500-1900 45: 1-22.

Ellinghausen, Laurie. 2008. Labor and Writing in Early Modern England, 1567-1667. Aldershot/Burlington: Ashgate.

Ezell, Margaret J.M. 1999. Social Authorship and the Advent of Print. Baltimore: John Hopkins University Press.

Ezell, Margaret J.M. 1992. 'The Gentlemen's Journal and the Commercialization of Restoration Coterie Literary Practices' in Modern Philology 89(3): 323-40.

Gallagher, Catherine. 1994. Nobody's Story: The Vanishing Acts of Women Writers in the Marketplace 1670-1820. Oxford: Clarendon Press.

Geerdink, Nina. 2012. Dichters en Verdiensten. De sociale verankering van het dichterschap van Jan Vos (1610-1667). Hilversum: Verloren.

Griffin, Dustin. 2014. Authorship in the long Eighteenth Century. Newark: University of Delaware Press. 
Hammond, Brean. 1997. Professional Imaginative Writings in England, 1670-1740: 'Hackney for Bread' Oxford: Clarendon Press.

Hobby, Elaine. 1988. Virtue of Necessity: English Women's Writing 1649-88. London: Virago.

Hoftijzer, Paul. 2001. 'Women in the Early Modern Dutch Book Trade' in Van Dijk, Suzan et al (eds) Writing the history of women's writing. Amsterdam: KNAW: 211-22.

Hunt, Tamara. 1996. 'Women's Participation in the Eighteenth-Century English Publishing Trades' in Leipziger Jahrbuch zur Buchgeschichte 6: 47-66.

Kernan, Alvin. 1989. Samuel Johnson and the Impact of Print. Princeton: Princeton University Press.

King, Kathryn. 2002. 'Elizabeth Singer Rowe's Tactical Use of Print and Manuscript' in Justice, G.L. and N. Tinker (eds.) Women's Writing and the Circulation of Ideas: Manuscript Publication in England, 1550-1800. Cambridge: Cambridge University Press: $151-81$.

Lehmstedt, Mark. 1996. “'Ich bin nun vollends zur Kaufmannsfrau verdorben' ”. Zur Rolle der Frau in der Geschichte des Buchwesens am Beispiel von Friederike Helene Unger (1751-1813)' in Leipziger Jahrbuch zur Buchgeschichte 6: 81-154.

Loewenstein, Joseph. 2000. 'Wither and Professional Work' in Marotti, A.F., M.D. Bristol (eds) Print, Manuscript and Performance. Columbus: Ohio State University Press 2000 .

McDowell, Paula. 1998. The Women of Grub Street: Press, Politics, and Gender in the London Literary Marketplace, 1678-1730. Oxford: Clarendon Press.

Parker, Deborah. 1996. 'Women in the Book Trade in Italy, $1475^{-1620 '}$ in Renaissance Quarterly 49(3): 509-41.

Pender, Patricia and Rosalind Smith (eds). 2014. Material Cultures of Early Modern Women's Writing. Basingstoke: Palgrave MacMillan.

Pettegree, Andrew. 2010. The Book in the Renaissance. New Haven/London: Yale University Press.

Prescott, Sarah. 2003. Women, Authorship and Literary Culture, 1690-1740. Houndmills/ New York: Palgrave MacMillan.

Rose, M. 1993. Authors and Owners: the Invention of Copyright. Cambridge, MA: Harvard University Press.

Rose, M. 1988. 'The Author as Proprietor' in Representations 23: 51-85.

Schellenberg, Betty. 2005. The Professionalization of Women Writers in EighteenthCentury Britain. Cambridge: Cambridge University Press.

Sheridan, G. 2001. 'Women in the Book Trade in the 18th Century: An Untold Story' in Van Dijk, Suzan et al (eds) Writing the history of women's writing. Toward an international approach. Amsterdam: KNAW: 197-210

Sheridan, G. 1992. 'Women in the booktrade in eighteenth-century France' in British journal for Eighteenth-Century Studies 15: 52-69. 
Smith, Helen. 2015. Grossly Material Things. Women and Book Production in Early Modern England. Oxford: Oxford University Press.

Stanton, Judit. 1988. 'Statistical Profile of Women Writing in English from 166o to 180o' in Keener, Frederick and Susan Lorsch (eds) Eighteenth-Century Women and the Arts. New York: Greenwood Press: 247-54.

Turner, Cheryl. 1992. Living by the Pen. Women Writers in the Eighteenth Century. New York/London: Routledge.

Turnovsky, Geoffrey. 2010. The Literary Market. Authorship and Modernity in Old Regime France. Philadelphia: University of Pennsylvania Press.

Viala, Alain. 1985. Naissance de l'écrivain. Sociologie de la littérature à l'âge classique. Paris: Minuit.

Woodmansee, M. 1984. 'The Genius and the Copyright: Economic and Legal Conditions of the Emergence of the Author' in Eighteenth Century Studies 17(4): 425-28.

Wright, Gillian. 2013. Producing Women's Poetry. Text and Paratext, Manuscript and Print. Cambridge: Cambridge University Press. 


\title{
Women Authors' Reputation and Its Relationship to Money Earned: Some Early French Writers as Examples
}

\author{
Suzan van Dijk
}

This chapter focuses in the first place on the reception of a number of French female authors, more particularly on the ways in which they were presented in bio-bibliographical compilations which were quite numerous in France in the late eighteenth and in the nineteenth century. While presenting some of their authors, compilers like Joseph de La Porte (Histoire Littéraire des Femmes Françaises, 1769), Boudier de Villemert (Notice Alphabétique des Femmes Célèbres en France, 1779) and Henri Carton (Histoire des Femmes Écrivains de la France, 1886) did consider the financial aspects of the writers' careers.

Their remarks are not to be considered as simple information: they are full of suggestions which, for a selection of these women (eighteenth century), are looked at more closely here and compared - as far as possible - to information available in other documents (private correspondence of the authors, paratexts). This chapter also compares what is being said about the money earned, invested or lost, to other elements in the presentation of the author's work and personality: what kind of role this particular aspect played in the process of (de)canonization of the authors concerned?

Professional authorship requires not just writing skills, some spare time and "a room of one's own", it implies also a relationship with money and financial affairs. ${ }^{1}$

1 I thank Hilde Hoogenboom for carefully reading an earlier version of this text. 


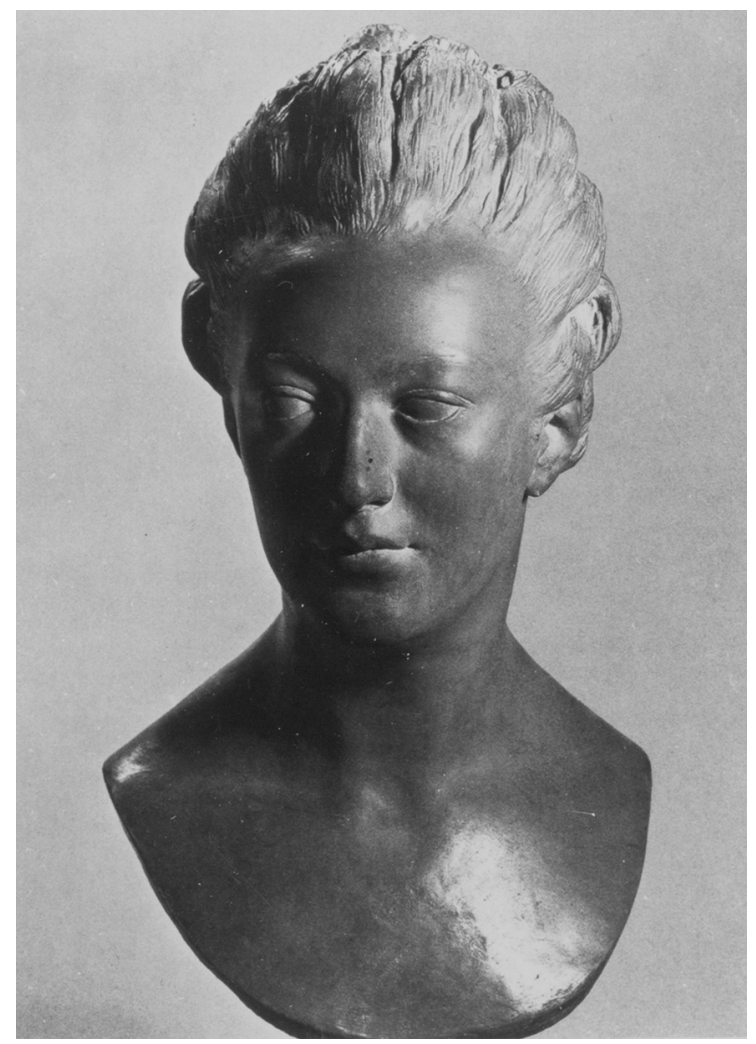

FIGURE 2.1 Isabelle de Charrière. Bust in plaster by Jean-Antoine Houdon, 1771. Bibliothèque publique et universitaire, Neuchâtel.

This can be a bad relationship, as the Dutch-Swiss author Belle van Zuylen/ Isabelle de Charrière (1740-1805) writes about at the end of her life. She then remembers Madame Tronchin, her doctor's wife, saying to her that she would never earn any money by her books: "stop thinking you might get some money thanks to your writings $[\ldots]$ you will never gain anything".

2 "Ne songez plus à tirer de l'argent de ce que vous pourriez écrire. [...]. Jamais vous n'y gagnerez la moindre chose"; letter 2504 (Isabelle de Charrière to baron Gérard Godart Taets van Amerongen van Schalkwijk, February 1804, in Isabelle de Charrière/Belle de Zuylen, CEuvres Complètes, ed. Jean-Daniel Candaux et al., Amsterdam 1984, vol. vi, 564 - from now on: $O . C$.). This correspondence is also being made available on-line; cf. Suzan van Dijk and Maria Schouten, "Numériser les lettres de Belle de Zuylen: Un regard plus précis sur les rapports familiaux", Cahiers Isabelle de Charrière / Belle de Zuylen Papers, 8 (2013), 24-44. 
In spite of having published a number of novels, theatre pieces and other texts, Isabelle de Charrière has to admit, in 1804, that Madame Tronchin was right, and she is ashamed about not having been successful enough in this financial sense:

although I never really gave up the idea, on the contrary wished to be able to pay a debt, or to make a gift with the money I would have gained, I eventually had to give up and to be happy without it - which was not possible without being slightly ashamed about it. ${ }^{3}$

It is not sure that Madame Tronchin ${ }^{4}$ intended to suggest a direct relationship between literary quality and money earned, but Charrière's being "ashamed" seems to point to her feeling it in this way. Any author (either male or female) could have felt like that. And also later historiographers might have established a connection and drawn conclusions from it.

In the present chapter I want to discuss this relationship between early French women's writing and the authors' financial situation - not focusing on the financial benefit the women themselves would have received from their literary labour, but on the role this being rewarded may have played in enhancing the authors' subsequent reputation: was it remembered as relevant from some perspectives? What was the importance of these financial aspects within the global image building around French female authors, as it took place in a particular genre of books: bio-bibliographical compilations inventorying, presenting and describing exceptional, curious, or otherwise interesting women or women authors? These kinds of books provide interesting source material, informing us about the pre-19oo reception of female writings. ${ }^{5}$

3 “[...] quoique je n'y aie jamais renoncé formellement, désirant au contraire tantôt de payer une dette, tantôt de faire un présent avec l'argent que j'aurais gagné, il a bien fallu y renoncer de fait, c'est-à-dire m'en passer, ce que je n'ai pu faire sans rougir un peu de ma profonde maladresse"; Ibid.

4 Who appreciated Charrière's writings, $c f$. letter 763 (Anne-Caroline Tronchin-Boissier to Isabelle de Charrière, 26 February 1791, in O.C., vol. III, 279).

5 We include these data in the WomenWriters database for comparative research we are carrying out within a series of research projects, described for instance in Suzan van Dijk, Anke Gilleir and Alicia Montoya, "Before NEww (New approaches to European Women's Writing). Prolegomena to the Launching of an International Project", Tulsa Studies in Women's Literature, 27/1 (2008), 151-57. Recently this database was transformed, thanks to the European HERA project Travelling TexTs (2013-16), into the NEWw VRE (http://resources.huygens. knaw.nl/womenwriters); this tool is central to the collaboration in the DARIAH Working Group Women Writers in History. 


\section{How to Approach the Genre}

Inventories or bio-bibliographical compilations of famous or exceptional women were a popular genre in different European countries, since it had been invented by Boccaccio, to whose De Mulieribus Claris (About Famous Women, 1375) Christine de Pizan reacted in her Livre de la Cité des Dames (Book of the City of the Ladies, 1405). The genre was continued through the eighteenth century, in particular with Joseph de La Porte's Histoire littéraire des femmes françaises (Literary History of French Women, 1769); and flourished in the nineteenth century. Hilde Hoogenboom has made an inventory of the different specimens and studied the genre and its development over the centuries in different countries of Europe. ${ }^{6}$ Some countries were more prolific in producing these compilations than others: in France, for instance, the genre is much more present than in the Netherlands. Compilers were men in most cases, but some women also followed Christine de Pizan's example. These men and women contributed to providing women writers with their due place, since they were often not included in literary historiography: in particular during the nineteenth century with literary history developing and excluding more and more those pre-180o women who had been relatively familiar to their contemporary readers. In this sense the genre of the bio-bibliographical compilation of famous women was important. The genre contributed (although in a way little acknowledged until now) to preserving many names of women writers, and to informing about the significance that was ascribed to them, and for which literary historians did not account.

In most cases the compilers were presenting or paraphrasing information that was available elsewhere. They tended to repeat or rework what had been published earlier, for instance in the periodical press, and they were also repeating each other. ${ }^{7}$ Compilers especially focused upon elements of these women's lives that they apparently considered relevant for female authorship, though in some cases this biographical information seemed to be quite far from the women's texts: the writers' beauty, the early age at which the women would have started writing, the marital status, and their financial situation. Not all of those aspects were discussed for each of the authors: this of course very much depended on available information and perhaps other factors.

6 Hilde Hoogenboom, "The Community of Letters and the Nation State: Bio-Bibliographic Compilations as a Transnational Genre around 1700", in Women Telling Nations eds. Amelia Sanz, Francesca Scott and Suzan van Dijk, Amsterdam/New York 2014, 273-92.

7 Cf. my article "L'abbé de La Porte et la canonisation des romancières du XVIIIe siècle: Le cas de Françoise de Graffigny", Romanistische Zeitschrift für Literaturgeschichte/Cahiers d'histoire des littératures romanes, 21/1-2 (1997), 43-54. 
Just as remarks about the authors' beauty, or their early predispositions for writing, the comments about their finances need not be considered only as mere information. We can even wonder if this information is itself reliable. Here I will not check these details with what can be found in other documents (such as private correspondence or the authors' paratexts). ${ }^{8}$ Given the fact that they seem to be quite suggestive, I will look into them in connection with the evaluation of the writings. I will compare what is said about the money earned - or owned, or lost to the global appreciation of the author's work and personality: what kind of role did this particular aspect play in these compilers' invitation to remembrance? ${ }^{9}$

In order to discuss their ways of presenting pre-180o women authors, I will focus on some eighteenth-, nineteenth- and early twentieth-century compilers, including Joseph de La Porte, already mentioned author of the important 5-volume collection presented in 1769: Histoire Littéraire des Femmes Françaises. La Porte inspired most of his followers, who sometimes openly refer to his work - even Jean Larnac in his early twentieth-century book, which is the most recent representative of the genre discussed here. However, I take as a starting point for my demonstration Henri Carton's Histoire des Femmes Écrivains de la France (History of the Women Authors of France, 1886), selected because of the large number of women he chooses to include in his book, and because of his objective, which is clearly to elicit sympathy towards these authors. In the first pages, he specifies that one has "too easily stated that women were intellectually inferior"; ${ }^{\prime 0}$ he wants to subvert this prejudice. After describing the way in which Carton realized his intentions and dealt with the authors those at least for whom financial aspects are under discussion - I will compare his statements to those of some predecessors and successors, trying to assess Carton's degree of real 'women-friendliness' or perhaps even 'feminism'.

\section{Carton 1886}

In his overview Carton presents 126 women he considers as French authors: $5^{1}$ of those were active during the nineteenth century, while 75 manifested

8 This will be done later in the chapter.

9 This article is part of a larger project studying also other aspects, which we may consider irrelevant from the point of view of literary history, and yet are discussed by biographers and historians in relation to women authors. See for instance: Suzan van Dijk, "Présentations et jugements: beauté ou laideur attribuées à des romancières et à leurs personnages féminins", in Le corps romanesque. Images et usages topiques sous l'Ancien Régime eds. Monique Moser-Verrey, Lucie Desjardins, Chantal Turbide, Québec 20o9, 245-66.

"trop facilement affirmé l'infériorité intellectuelle des femmes" (2). 
themselves between the early Middle Ages and the beginning of the nineteenth century (lines are sometimes difficult to draw in between centuries). The memory of the 75 early writers had at least survived until the end of the nineteenth century. ${ }^{11}$ Given the scope of the present volume, I will now focus on these pre-18oo authors: the numbers per century show their gradually increasing number - according to Carton's perspective (which obviously can be seen as corresponding to some form of consensus):

$\begin{array}{lr}\text { Middle Ages } & 7 \\ \text { sixteenth century } & 14 \\ \text { seventeenth century } & 22 \\ \text { eighteenth century } & 32 \\ \text { Total pre-180o women } & 75\end{array}$

The women's reputation or fame is certainly very diverse. This is reflected in the different word count and number of pages devoted to each author, as well as in the presence or absence of a portrait. For 18 women, no more than their names are mentioned. For another 33, some information is provided, but not exceeding two pages. 24 authors have three or more pages dedicated to them; the most heavily present are: Mme Roland (1o pp.), Mmes du Deffand and Rambouillet (11 pp.), Marguerite de Navarre and Louise Labé (13 pp.), Mme de Sévigné (14 pp.), with the maximum of 20 pages for Mme de Staël. Those for whom a portrait is added are: Mme Deshoulières, Mme de Sévigné (both seventeenth century), and for the end of the eighteenth century Mme Roland and - again - Mme de Staël.

The larger numbers of pages can of course be interpreted as signs of the women's success, but the word "success" itself is not often used. It is noted with regard to the following seven authors:

Deshoulières, A. (1637-94) 5 pp. let us be honest and say that her miserable rhymes obtained much more success than her opera ${ }^{12}$

\footnotetext{
11 Isabelle de Charrière is not one of those; she was returned to collective memory thanks to Philippe Godet's biography (Philippe Godet, Madame de Charrière et ses amis (1740-1805). Genève 1906), and again by Van Oorschot (in the O.C. 1979-84).

12 "ayons la franchise de dire que ses misérables rimes [..] eurent beaucoup plus de succès [que son opéra]", 103 .
} 
Graffigny (1695-1758) 4 pp.

Labé (1526-66) 13 pp.

Lafayette (1634-93) 4 pp.

Scudéry (16o7-1701) 9 pp.

Staël (1766-1817) 20 pp.

Tencin (1685-1749) 6 pp. one has a right to be surprised about the wonderful success obtained by this text ${ }^{13}$ all these successes seemed to heighten her the more above other women ${ }^{14}$ this book [Zaïde] had a great success ${ }^{15}$ and yet these lengthy novels obtained the most impressive success ${ }^{16}$ very seldom did he applaud at his daughter's successes ${ }^{17}$ quoting La Harpe: a success equal to that obtained by Lafayette and her Princess of Cleves ${ }^{18}$

These are definitely women now considered as authors who deserve to be mentioned in literary history, and it is a bit strange not only to see the very different amounts of attention (number of pages) dedicated to their works, but also to notice that the word "success" is in fact not easily used for women's succeeding as a writer. The only occasion where we find a simple and straightforward recognition of a woman's book being successful concerns Mme de Lafayette, and strangely enough not La Princesse de Clèves (1678), but her earlier, more traditional novel Zaïde (1669). We notice the difference when seeing the lateeighteenth-century critic La Harpe being quoted for Mme de Tencin: he insisted upon the innovative novel being - in the long run - the most successful and important. Comparing Tencin's work to La Princesse de Clèves was indeed a way of signifying her success. In the other cases, mentions of the women's successes are accompanied by expressions of surprise, or even of some form of denial.

Noteworthy in this respect is Carton's unclear definition of woman author. For at least 22 (out of the 75 mentioned) we are not informed about the women having published anything substantial or even their having composed other texts than private letters. The fact is sometimes explicitly mentioned: "The Marchioness [de Rambouillet] did not leave any written production". ${ }^{19}$ And it applies not just to those women for whom only the name was dropped like Modeste Dupuis and Philiberte de Fleurs (sixteenth century), but also

\footnotetext{
13 “on a droit de s'étonner du succès prodigieux qu'obtint alors cet écrit", 163.

14 "tous ces succès parurent l'élever encore davantage au-dessus de son sexe", 6o.

15 “Ce livre obtint un grand succès", 121.

16 "Et pourtant ces volumineux romans obtinrent alors le succès le plus retentissant", 9 o.

17 "il applaudissait rarement aux succès de sa fille", 194.

18 "succès égal à celui de Lafayette et sa Princesse de Clèves", 170.

19 "La marquise n'a laissé aucun ouvrage", 88.
} 
to personalities who were rather more famous: those women were not well known as authors, but as salonnières for instance, like Mmes de Rambouillet and du Deffand (seventeenth century). This makes it of course difficult to study the degree of success of these authors, as well as the relationship between their writing and forms of financial reward, which probably point at their success.

\section{Money}

In this context I want to consider Carton's way of discussing the women's relationship to money. For 10 of his pre-180o authors, mention is made of money in some form or another. A first question might be: when mentioning any financial aspect of the women authors' lives, does he use money as a way of illustrating indirectly the success of the work(s)? Is there a connection to be felt here between the mention of financial reward and the compiler's potential admiration? Having seen how reluctantly he speaks about women's successes, the question is relevant. On the other hand, we are well aware ${ }^{20}$ that at the time any money a woman would have earned belonged to her husband. Taking this literally, however, would imply that all those women who actually did not depend on a husband, such as widows (having married as a young girl a much older man) and those women who chose not to marry, or to leave their husband, would have to be left aside. Most of the women we will discuss here belonged to one of those categories. Carton himself had also noticed: "An observation to be made, although it must have already come to the reader's mind, is that up to that period, most of the women who made themselves a name, more or less famous, in literature, were not happy in marriage". ${ }^{21}$ Being "unhappy in marriage" is the way in which Carton formulates the situation, although clearly Riccoboni will not have been the only one who

20 And so was Isabelle de Charrière, who wrote about this: "the people of the Vaud region would be similar to the women of all countries who, excluded from government, and not being legally masters of their fortunes or even their persons, do not feel for that reason miserable, and who in thousands of ways use their talents and capacities" ("les habitants du Pays de Vaud [ressembleraient] aux femmes de tous les pays, qui exclues du gouvernement, et n'étant pas même légalement les maîtresses de leur fortune ni de leur personne, ne s'en croient pas, pour cela, plus à plaindre, et usent de mille manières satisfaisantes de leurs talents et de leur capacité", in "Réponse à l'écrit du Colonel de La Harpe, intitulé: De la neutralité des gouvernants de la Suisse depuis l'année 1789" in O.C. $\mathrm{X}, 279)$.

21 “Une remarque à faire, quoiqu'elle se soit présentée sans doute déjà à l'esprit du lecteur, c'est que, jusqu'à cette époque, la plupart des femmes qui se sont fait un nom plus ou moins illustre dans la littérature, n'ont pas été heureuses en ménage", 164. 
experienced her widowhood as an important relief. ${ }^{22}$ All these women may have needed the money - unlike, actually, Isabelle de Charrière, for whom it was rather symbolic. ${ }^{23}$

Here the focus is on the way in which these facts (or whatever was considered as such) contributed to their reputation, or at least if these were included in Carton's presentations of these women. For the following pre-18oo writers (presented in alphabetical order), Carton includes an observation or comment about any financial aspect of their life:

Alexandrine de Bawr

(1773-186o)

Anne-Marie du Boccage

(1710-1802)

Gabrielle-Emilie du

Châtelet (1706-1749)

Christine de Pizan

(1364-1430) several misfortunes forced Mme de Bawr to ask her pen

to provide her with a means of subsistance ${ }^{24}$

Her husband's death left her at an early age in the

possession of a good fortune, free to dedicate herself to litterature $^{25}$

Her high birth, her fortune, not less than her talents, made her interesting as a potential bride to a great many of noble young men ${ }^{26}$

perhaps the first woman in France who thought about living by her pen ${ }^{27}$

22 Antoine-François Riccoboni died May 14th 1772; June 3th Marie-Jeanne Riccoboni, who although separated from him had taken care of him during his illness, writes to her friend Robert Liston: "Everything has changed, everything is over. So, my friend, I will not send you any further complaints, and my head will be free to think about the comedy that I mentioned (Tout est changé, tout est fini. [...] Ainsi, mon ami, je ne vous écrirai plus des lamentations et ma tête sera plus libre pour songer à la comédie dont je vous ai parlé; James C. Nicholls (ed.), Mme Riccoboni's Letters to David Hume, David Garrick and sir Robert Liston, 1764-1783, Oxford, 247, 248).

23 Here, those Charrièristes, who after Simone de Beauvoir had been worrying about Charrière's happiness in marriage, might disagree. They might consider that the author would have preferred to leave her husband. After all, in spite of her owning some properties in the Netherlands, she was not financially independent. Yet, see: Janet Whatley, "The Engaged Life of a Quiet Man: Charles-Emmanuel de Charrière", Cahiers Isabelle de Charrière / Belle de Zuylen Papers 3 (2008), 11-23.

24 "diverses infortunes obligèrent Mme de Bawr de demander à sa plume un moyen honorable d'existence", 212.

25 "La mort de son mari [...] la laissa, jeune encore, en possession d'une assez belle fortune et libre de se livrer entièrement à son goût pour la littérature", 160.

26 "Sa naissance, sa fortune, non moins que ses talents, la firent rechercher en mariage, toute jeune encore, par beaucoup de nobles personnages", 135 .

27 "peut-être la première femme en France qui ait pensé à vivre des produits de sa plume", 34 . 
Sophie Cottin

(1770-1807)

Stéphanie de Genlis

(1746-1830)

Marie-Thérèse Geoffrin

(1699-1777)

Marie de Gournay

(1565-1645)

Louise Labé

(1526-66)

Marie-Jeanne Riccoboni

$(1714-1792)$ one of her friends, who had been sent into exile, needed 50 louis in order to leave France, and escape the executioners. Mme Cottin quickly gathered the pages she had been writing, sold them immediately [..] She kept it totally secret ${ }^{28}$

a 6000 franks pension [..] she could actually live off the returns of her too numerous publications ${ }^{29}$

Her husband did not have an important role in her life apart from providing her with the fortune which was the starting point for the consideration she succeeded in acquiring ${ }^{30}$

she dedicated them to the cardinal de Richelieu, who provided her with a royal pension ${ }^{31}$

found in the fortune of her husband new means for satisfying her passion for literature [as a reader $]^{32}$ However, fame did not bring her riches. The small pension she was given by the Royal Court, was stopped during the Revolution ${ }^{33}$

Comparing these cases, we conclude here that several women - many of them indeed living alone for whatever reason from some moment of their career are described as having been paid for their writings: either by receiving royal, annual pensions (Gournay, Genlis, Riccoboni) or by selling their production (Christine, Genlis, Cottin, Bawr). ${ }^{34}$ And we take note that Carton chose to mention this. We may assume that on this level the information is exact.

28 "un de ses amis, qui venait d'être proscrit, avait besoin de cinquante louis pour pouvoir sortir de France et dérober sa tête aux bourreaux. Mme Cottin rassembla à la hâte les feuilles éparses qu'elle venait d'écrire, les vendit de suite [...] Elle garda le plus profond secret", 174 .

29 "pension de six mille francs [...] Elle pouvait vivre d'ailleurs du produit de ses trop nombreux ouvrages", 178 .

30 "Son mari ne compta guère dans sa vie, sinon pour lui assurer la fortune qui fut le point de départ de la considération qu'elle sut acquérir", 158 .

31 "Elle les [ses Essais de Montaigne] dédia au cardinal de Richelieu qui lui fit donner une pension du Roi", 73 .

32 "trouva [..] dans la fortune de son mari de nouveaux moyens de satisfaire sa passion pour les lettres [sc. en tant que lectrice]", 62.

33 "Mais avec la réputation, Mme Riccoboni n'avait pas trouvé la fortune. La petite pension que lui faisait la Cour fut supprimée par la Révolution", 167.

34 Note that reference is here to information provided by Carton. According to other sources Bawr and Du Boccage, for instance, also received annual gratifications. 
But the facts are complemented with some connection to the traditional women's role: being (or having been) someone's wife, or being helpful to others in a more general sense. Help, in any form, was seen as an appropriate, and actually feminine, motivation for earning money (Gournay, Cottin): it compensated for the 'unfeminine' impression given by the act of publishing. Marriage and issuing books went less well together. ${ }^{35}$ Marriage and financial well-being appear clearly linked to each other (as of course they actually were in historical "real life"), so there was no need to earn money - as is illustrated by (the not publishing) Geoffrin. On the other hand, thanks to marrying wealthy men, Labé and Du Boccage were able to become authors - the fact could be openly mentioned. ${ }^{36}$ An interesting exception is provided by Du Châtelet: she was the one who was rich, thanks to her own parents, which was again a quite honourable fact.

Living by one's pen and making money from one's writing talents must have been, according to Carton's perspective, a risky decision. In the same way that the word success had - for women authors - negative connotations, we notice the negativity associated with two of the most successful (in commercial terms) women authors: Marie-Jeanne Riccoboni and Stéphanie de Genlis. ${ }^{37}$ Speaking about Riccoboni, Carton adds what might seem to be a warning: fame does not provide money! And for Genlis the recognition of her success, in terms of money, is accompanied by a reproach about her works being too numerous. On the other hand, Carton seems to approve of Genlis' decision to sell her writings, a decision also made by the (supposedly) first, and by the most recent, female author of our list. Both women, Christine de Pizan and Alexandrine de Bawr, turned to this solution, once their husbands had died, leaving them widows at about 25 years of age. In this case earning one's living by selling one's writings is explicitly presented as "honorable". There is, most probably, no connection with Carton's opinions concerning the women's talents: Christine de Pizan's fame had survived over the centuries, and still survives today; Mme de Bawr, although translated at the time into Spanish, German and Dutch, ${ }^{38}$ undoubtedly enjoyed a smaller reputation in France when Carton wrote his book, and has since fallen into oblivion.

35 It is indeed the women's "going public" that was at the heart of the problem - cf. the title of Elizabeth Goldsmith's book Going Public: Women and Publishing in Early Modern France, Ithaca 1995.

36 Both husbands died earlier than their wives: Du Boccage was 57 when she lost her husband, Labé 31; they lived, respectively, 35 and 9 more years.

37 Both left their husbands at some moment in their lives.

38 At least five translations between 1813 and 1863 . 
Is this approval of Mme de Bawr's decision to be seen as a way of adopting a more modern attitude toward (nearly) contemporaries? George Sand, the most prominent of the nineteenth-century writers he is discussing, had of course given an example in this domain. Carton knows about the path she had followed: she "tried to create financial resources allowing her an independent life. She translated, drawed portraits [...], but all that was not financially rewarding; she then decided to write". ${ }^{39} \mathrm{He}$ even has no hesitation in saying that she had "the most wonderful success", 40 the more so of course as 10 years earlier, in 1876, he must have been aware that newspapers all over Europe had announced her death and published extensive obituaries.

\section{Comparing}

Having seen all this, it is still unclear however what we are actually trying to understand: Carton's private opinion? The typical (male?) discourse to be found in these compilations? The common opinion held by nineteenth-century French (male?) people, and simply reflected here? There is a clear need at least to compare Carton's presentation to those of some colleagues. Considering that our sample is sufficiently random, we have checked the presence of these 10 pre-180o authors in a number of other compilations:

- Joseph de La Porte, Histoire Littéraire des Femmes Françaises (1769)

- Catherine J.F. Girard de Propiac, Le Plutarque des Jeunes Demoiselles (The Young Ladies' Plutarch, 1806)

- Alfred de Montferrand, Les Femmes Célèbres Contemporaines Françaises (French Present-day Female Celebrities, 1843)

- P. Jacquinet, Les Femmes de France Poètes et Prosateurs (The Women of France, Poets and Prose writers, 1886)

- F. Desplantes et P. Pouthier, Les Femmes de Lettres en France (Women of Letters in France, 1890 $)^{41}$

39 "chercha à se créer des ressources qui lui permissent de mener une vie indépendante. Elle fit des traductions, dessina des portraits [...], mais tout ce travail était peu lucratif; elle eut alors l'idée d'écrire", 228. In her autobiography Histoire de ma Vie she insists upon her decision, having left her husband, to write and publish (George Sand, Histoire de ma Vie [1854-55], Paris 1970, 2 vols.). In her correspondence, she discusses in detail the contracts with her publishers (La correspondance de George Sand ed. Georges Lubin, Paris 19641991, 25 vols.).

$40 \quad$ "le plus éclatant succès", 228.

41 Note that Desplantes and Pouthier's work was reprinted in 1970 (Slatkine reprints Genève). 
- Jean Larnac, Histoire de la Littérature Féminine en France (History of Female Literature in France, 1929)

These works are not completely similar in scope to Carton's: his three closest contemporary colleagues present a smaller number of women than he does, and the immediate predecessor, Montferrand, focuses on more recent authors. Jacquinet's work is an anthology with a "notice" for each of the authors, where their' lives and works are described in some detail. La Porte's compilation, the impressive 5-volume work, is considered here as a potential starting point for the other compilers. ${ }^{42}$ These include not only Propiac, who around 1800 was addressing young girls, but also Larnac, writing in the early twentieth century. In his preface the latter refers explicitly to the Histoire Littéraire des Femmes Françaises, observing that it is "a series of monographs rather than real history writing". ${ }^{43}$ This is in fact true for most works other than Larnac's Histoire de la Littérature Féminine, where indeed an evolution is being described, comparisons made between different authors and connections described with the larger literary field. The table below further illustrates the differences between the works by mentioning differences in numbers of women discussed:

\begin{tabular}{lcc}
\hline & Authors total & Authors pre-180o \\
\hline La Porte 1769 & 259 & 259 \\
Propiac 1806 & 76 & 76 \\
Montferrand 1843 & 43 & 9 \\
Carton 1886 & 126 & 75 \\
Jacquinet 1886 & 37 & 29 \\
Desplantes/Pouthier 1890 & 24 & 18 \\
Larnac 1929 & 311 & 229 \\
\hline
\end{tabular}

Obviously, not all women discussed by Carton are present in the other inventories. Reasons for eliminating some of them are, per definition, not provided, and have to be found probably in considerations about the intended readership or possible volume of the book, perhaps also in sudden insights

\footnotetext{
42 It is not; see for instance the earlier compilation (also included in the SIEFAR website) by Hilarion de Coste: 1647. Some of the eighteenth-century works have been left aside now for practical reasons, and also because the nineteenth-century compilers tend to be more explicit about the financial aspects of the women's lives.

43 "un ensemble de monographies [plutôt] qu'une histoire veritable".
} 
concerning the importance of other works. More precisely, those 10 authors for whom Carton discussed some financial aspects of their writing careers do not each of them appear in the other compilations. The following overview concerns the recurrence, in the successive books, of any of these 10 authors, for whom we will again compare the ways in which the compilers discuss money in relation to female authorship:

\begin{tabular}{|c|c|c|c|c|c|c|c|}
\hline & $\begin{array}{l}\text { La Porte } \\
1769\end{array}$ & $\begin{array}{l}\text { Propiac } \\
1806\end{array}$ & $\begin{array}{l}\text { Montfer- } \\
\text { rand } 1843\end{array}$ & $\begin{array}{l}\text { Carton } \\
1886\end{array}$ & $\begin{array}{l}\text { Jacquinet } \\
1886\end{array}$ & $\begin{array}{l}\text { Desplantes/ } \\
\text { P. } 1890\end{array}$ & $\begin{array}{l}\text { Larnac } \\
1929\end{array}$ \\
\hline Bawr & & & $\mathrm{x}$ & $\mathrm{x}$ & & & o \\
\hline Boccage & $\mathrm{x}$ & o & & $\mathrm{x}$ & o & & o \\
\hline Châtelet & o & o & & $\mathrm{x}$ & o & o & o \\
\hline Christine & & $\mathrm{x}$ & & $\mathrm{x}$ & $\mathrm{x}$ & $\mathrm{x}$ & $\mathrm{x}$ \\
\hline Cottin & & & & $\mathrm{x}$ & & & $\mathrm{x}$ \\
\hline Genlis & & & $\mathrm{x}$ & $\mathrm{x}$ & $\mathrm{x}$ & & $\mathrm{x}$ \\
\hline Geoffrin & & & & $\mathrm{x}$ & & & $\mathrm{x}$ \\
\hline Gournay & $\mathrm{x}$ & & & $\mathrm{x}$ & o & o & $\mathrm{x}$ \\
\hline Labé & $\mathrm{x}$ & $\mathrm{x}$ & & $\mathrm{x}$ & $\mathrm{x}$ & & $\mathrm{x}$ \\
\hline Riccoboni & $\mathrm{x}$ & $\mathrm{x}$ & & $\mathrm{x}$ & & & $\mathrm{x}$ \\
\hline
\end{tabular}

$\mathrm{X}$ : Author is mentioned/presented, financial aspects are discussed.

O: Author is mentioned/presented, no discussion of financial aspects.

I will compare now first between Carton and his closest contemporaries; follow then their potential influence on successors; from Larnac - who quotes La Porte - I go back to the predecessors.

\section{Montferrand 1843}

Carton's most immediate predecessor might not have been a direct source for him in 1886, given Montferrand's scope on recent authors. For those two women included by both Montferrand and Carton (Bawr and Genlis), each of the two compilers mentions their need for money. In Montferrand's book, however, this is much more developed, and apparently tailored to move the readers. Mme de Bawr's delicate situation is described in much detail, including her two successive marriages, the first one unhappy and finished by the husband divorcing her, the second one ending also in a catastrophe: after some years her second husband "died in the most horrible way: he was killed in the street by a 
cart transporting stones: its wheel was lost". ${ }^{44}$ This is why she felt obliged to use her writing talents to survive (29-31). Emotions generated for Genlis, whom Carton considered as too prolific, are different: they are not of pity, but rather admiration of her generosity. Thanks to her publications she paid a large part of the bail of three prisoners (fr. 46,ooo): "to free three gentlemen from their prisons". 45 It is appreciated as a "noble and generous use of her talents". 46

\section{Jacquinet 1886}

Presenting in the same year as Carton a much smaller collection of - not only contemporary - women, Jacquinet left out Bawr, Cottin, Riccoboni (the latter nowadays acknowledged as important), and also Geoffrin, who after all was neither a "poète" nor a "prosateur". In a general sense, and different from Carton, Jacquinet is not really an admirer of women's writing. In his "Introduction" he states that literary excellence is impossible for women (VII), but that reading their works can provide some entertainment to the (male?) "lettrés" (IX). ${ }^{47}$ He illustrates his low opinion of women's authorship by referring to "Mme du Boccage, a strong woman of letters, who was not lacking courage, but did lack genius" ${ }^{48}$ Her works "did not escape their destiny":49 they were forgotten (xv). In the same way, Jacquinet dismisses Christine de Pizan's work: "the imperfections and errors make it rather difficult to read her works". ${ }^{50}$

In such a context, there is no need to discuss financial rewards. For Genlis, he considers it is not her "educational clichés too easily repeated" that made her living, but her work as a "gouverneur" to the children of the Duc d'Orléans (354). ${ }^{51}$ If Christine de Pizan - in spite of the "imperfections" - earns her livelihood, the interesting thing is the context, generating both pity and admiration: the "cruel changes in her financial situation [...] the pain and distress of

44 "périt de la manière la plus funeste: il fut écrasé dans la rue par une voiture chargée de pierres, dont la roue se détacha de l'essieu". "pour retirer de leur prison trois gentilshommes".

46 "noble et généreux emploi de son talent".

47 In spite of the wish he formulates that his work might suggest to someone else the idea of writing "a book which would describe, as a large and coherent overview, the literary history of French women" (un livre, où se déroulerait, dans la teneur et l'ensemble d'une étude ample et suivie, l'Histoire Littéraire des Femmes Françaises, XXv). Note that he quotes La Porte's title without referring to him as the author.

48 "une forte lettrée, à qui le courage n’a pas manqué, à défaut de génie".

49 "n’ont pas échappé à leur destin".

50 "les imperfections et les défauts [...] rendent assez difficile la lecture de ses ouvrages", 15. This is what Wikipedia now writes about De Pizan: "In recent decades, Christine de Pizan's work has been returned to prominence". See https://en.wikipedia.org/wiki/Christine_de_Pizan. "banalités pédagogiques trop complaisamment ressassées", 351. 
early widowhood",52 and her strength in this situation: "In order to provide for her family and educate her children, she used - with male courage - the talents which had been the elegant amusement of her happy youth". ${ }^{53}$

For Louise Labé he also mentions the context of her wealth, Labé's father and husband being both members of the "riche bourgeoisie" (54), but does not appreciate the "passionate declarations of love" to be found in her poems. ${ }^{54}$ For Mademoiselle de Gournay he even avoids including any sign of appreciation (financial or other) for her work, apart from those dedicated to Montaigne, and speaks of her personality, which he profoundly dislikes because of her "oldfashioned stubbornness and superstitious love for things of the past". 55

\section{Desplantes/Pouthier189o}

For F. Desplantes and P. Pouthier, who - four years later - did not provide a preface or introduction, it is difficult to understand their intentions and selection. They rely heavily on predecessors, repeating for instance some of the typical items of the Du Châtelet's reception, often based on Voltaire's éloge: her writing considered as near to Pascal's, and a discussion of her being, or not, a femme savante. For Christine de Pizan - the only writer whose financial situation is not avoided - we find again insistence upon her comfortable life as a young girl, enjoying at the court "comfort near to richness". ${ }^{6}$ The "changes of fortune" (revers de fortune) are specified in order to generate compassion: her father and her husband died, and "creditors manifest themselves all over the place, considering themselves as stronger than a woman". ${ }^{57}$ The point is, again, her "energetic character" (caractère énergique, 9-10), that helped her in gaining some money by writing.

For Gournay, Richelieu's pension given to her is not mentioned, but she is situated in this "male" context, with portraits of the Cardinal and of course Montaigne. Negative opinions about her and the way in which some contemporaries ridiculed her are part of the narrative, but the authors take some distance: "she had several small ridicules, which generated some vivid reproaching"; 58 but their contemporaries would have seen in her "a remarkable character" (52).

$5^{2} \quad$ "cruels revers de fortune [..] la douleur et la détresse d'un veuvage prématuré".

53 "Pour faire vivre et élever sa famille, elle eut recours avec un viril courage aux talents qui avaient été l'élégante distraction de son heureuse jeunesse", 16 .

54 "abandon passionné des aveux".

55 "entêtement retrograde, engouement superstitieux pour le passé", 65 .

56 "une aisance voisine de la richesse", 8.

57 "les créanciers se dressent de toutes parts, espérant venir aisément à bout d'une femme".

$5^{8}$ "elle eut quelques petits ridicules qui lui furent parfois un peu vivement reprochés". 


\section{Larnac 1929}

The most recent of our receivers, Larnac, wanted to really write a "history". 59 This led him to include most of the women presented by Carton - being inspired either by him, or directly by La Porte, the first of the compilers discussed here. Our 10 cases are all present, and in most of them the mention of the financial side of the women's authorship has become a fixed attribute. Bawr, Boccage and Du Châtelet are exceptions: the first one is mentioned only as a regular guest in salons (163), the second as being "known" (connue, 152) and even "famous" (célèbre, 158), and the third one as a scientific translator who is not included in the literary world (155).

For the others: we again find Christine de Pizan as the young widow who succeeded in surviving difficult circumstances: there is some supplementary insistence on her being invited to the English court, which she refused (3031). Sophie Cottin is again the benefactor thanks to the success of Claire d'Albe (140), which allowed her to pay for the liberation of a (male) friend; Geoffrin having her, financially speaking, excellent marriage (140). Genlis is qualified as "all-mighty" (toute-puissante) in the cultural field, but in a quite neutral way, described as living by her pen: "as a living, she writes all kinds of books [..] Napoleon gives her a 6000 franks pension". ${ }^{60}$

In some cases, however, probably for the sake of narration, contrasts between the women are reinforced. Riccoboni, for instance, reappears here: her "universal fame" (renommée universelle) is opposed to the fact that she died in total misery (153). The contrast between the two contemporaries, Labé and Gournay, which was visible with Carton and Jacquinet, is now developed into an extensive comparison in which the financial aspect, however, plays a minor role. Clearly Louise Labé's advantage was facilitated by her marrying the "riche cordier Ennemond Perrin" (64). But this marriage itself is related to Louise's beauty and attractive personality - both denied to Marie de Gournay: "As opposed to Louise Labé, wonderful physics, emotive heart, Marie de Gournay, ugly spinster, pretended to be just a brain [...] Louise Labé was celebrated as a Goddess; Marie de Gournay was ridiculed mercilessly". ${ }^{11}$ The latter's being (also financially) protected by "great figures, such as Richelieu and Balzac" apparently was not helpful. ${ }^{62}$

59 He mentions his being indeed inspired by Jacquinet's suggestion (cf. n. 21).

6o "elle écrit, pour vivre, toutes sortes de livres [...] Napoléon lui accorde une pension de 6.000 francs", 165 .

61 "A l'opposé de Louise Labé, chair magnifique, cœur en émoi, Marie de Gournay, vieille fille laide, ne prétendait être qu'un cerveau [...]: Louise Labé fut fêtée comme une déesse; on se moqua de Marie de Gournay à l'envi', 68.

62 "quelques grands personnages, comme Richelieu et Balzac", 72. 


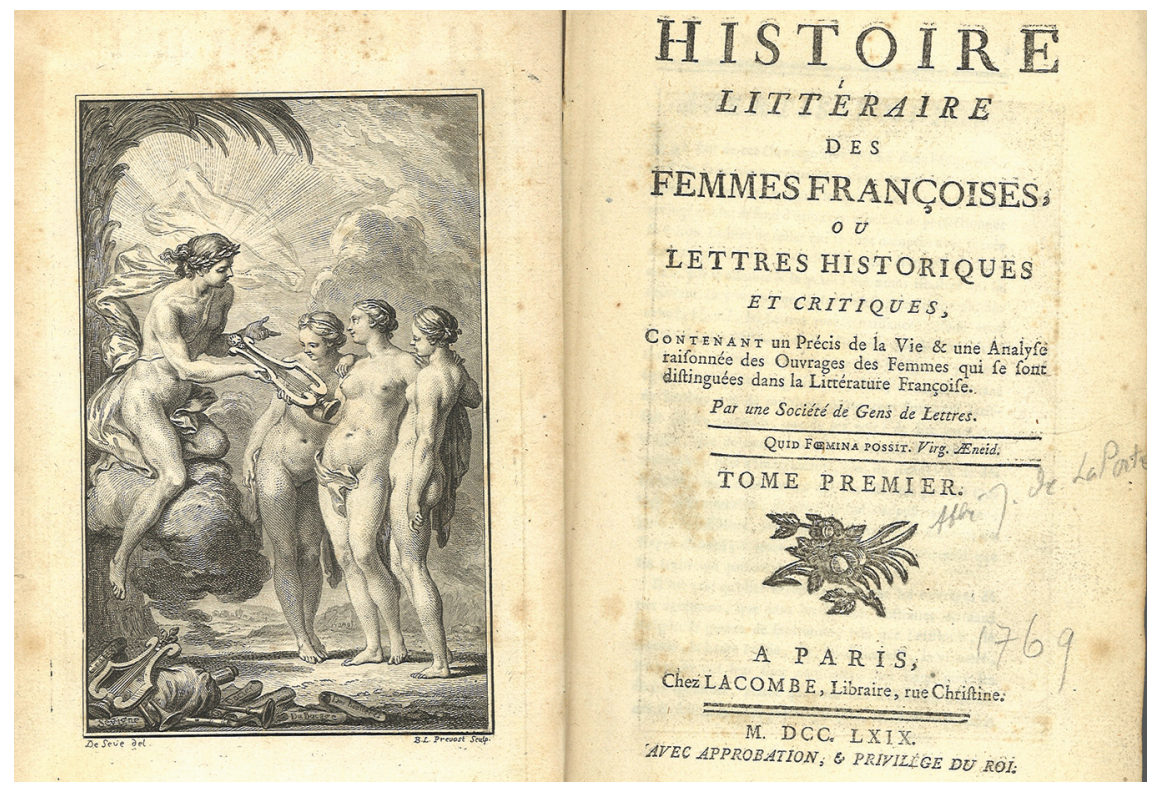

FIG URE 2.2 Joseph de la Porte, Histoire Littéraire des Femmes Françoises: ou, Lettres Historiques et Critiques, Contenant un Précis de la Vie et une Analyse Raisonnée des Ouvrage des Femmes qui se sont distinguées dans la Littérature Françoise, par une Société de Gens de Lettres. Paris: Lacombe, vol. I, title page.

\section{La Porte 1769}

Looking now back to the eighteenth century, we note that a considerable number of the authors mentioned by Carton were absent from La Porte's Histoire: they were not yet born or active in 1769 . For the others, La Porte tends to be much more nuanced than those who followed him. Monsieur du Boccage, for instance, now appears not only to be rich: La Porte insists on the couple's "equal love for littérature and perfect conformity of character". ${ }^{3}$ In La Porte's Histoire, Riccoboni is not just described as dying in poverty, but her own words are quoted, showing that there was also a personal choice: "I am not rich, but moderation always seemed to allow for compensation". 64

The two sixteenth-century women are still presented as separate individuals. Gournay is not that isolated, as the Cardinal de Richelieu provided her with a "pension du Roi" out of sympathy for her (I, 121). Labé is named "la belle Lyonnaise", but also "devoted herself to study", and her marriage to the

63 "égal amour pour les lettres [et] parfaite conformité de caractère", IV, 467.

64 "Je ne suis pas riche; mais la modération m’a toujours paru capable de suppléer à l'opulence: $[\ldots]$ je me passe de mille choses, sans m'en priver", $v, 2$. 
rich merchant allowed her to have "a library of the best authors in all kinds of writing". 65

\section{Propiac 1806}

Propiac's Plutarque des Jeunes Demoiselles is among the earlier of La Porte's followers. In his preface he explains the possibility and the need of using female authors as "modèles" for young girls (I, iii). This obliged him to eliminate those women whose conduct was reprehensible ... For him, Louise Labé was one of these. But although obliged "to keep silent about her private conduct", 66 he discusses her talents, her wit and her beauty, without forgetting the money of the rich husband, which had contributed to her fame.

However he clearly preferred those women who illustrated that "a modest condition is often preferable to riches and aristocracy". ${ }^{67}$ Riccoboni, speaking about her decision to refuse luxury and wealth, was of course a perfect case (II, 385). Referring to the women's conduct, interpreted perhaps in a particular way, also showed the importance of female modesty. One finds the 'information' that for quite some time, Anne-Marie du Boccage hid her talents: "adopting the manners of the good society of the time, she kept scrupulously to the norms of showing ignorance". 68 The same applied to Mme du Châtelet, for whom he specifies that she had been living in contexts where people ignored "what she was". 69

Christine de Pizan is also shown here as hiding something: strangely enough it is her poverty she would not have wanted others to be aware of. The energy so much admired in the other compilations apparently is seen as inappropriate in this book for young girls: the widow is presented as "unconsolable"; "tired"; "in a state of distress". ${ }^{70}$ The (financial) help and protection of "les grands", and "the high reputation she acquired" are mentioned,71 but she still is presented as feeling "a mortal displeasure when her needs obliged her to ask her friends for financial support". 72

65 "se livra à l'étude"; "une Bibliothèque des meilleurs Auteurs dans tous les genres", I, 73.

66 "de garder le silence sur sa conduite privée", I, 102,

67 "une condition commune est souvent préférable aux grandeurs", I, vi.

68 "se pliant au ton de la bonne compagnie du temps, elle observait jusqu'au scrupule les bienséances extérieures de l'ignorance", I, 312.

69 "ce qu'elle était", I, 288.

70 "inconsolable; fatiguée; dans un état de détresse", I, 177.

71 "la haute réputation qu'elle s'acquit".

72 "un déplaisir mortel quand la nécessité la forçait d'avoir recours à la bourse de ses amis", I, 18. 


\section{Normality}

A comparison of the successive compilations, for this relatively small number of pre-18oo authors presented by these compilers, cannot lead to any firm conclusions. The women, quite different persons and authors, are probably not what we might consider 'representative'. The compilers on the other hand also had their different opinions and intentions, addressed different kinds of readerships, and allowed themselves to include smaller or larger numbers of female authors and to enter into more or less detail. Yet, it seems that the examples we found at least point in a certain direction.

Over this century and a half the male compilers were perfectly aware of the fact that women's authorship was not "normal". This is actually the raison d'être of the compilations, and is formulated in the most striking - we may even say, shocking - way by Larnac near the end of his book: "This is the tragic side of female genius: it cannot exist within the happiness of normal life.".73 The question if normality of life guarantees happiness is not discussed, but in the very last chapter, entitled "Suggestions", Larnac goes on to explain differences between male and female lives: money being one of the determining factors in the male part of "normal" life.

It is of course not clear whether many or most of the women writers wanted to earn a living by their pens. We noticed its importance for Isabelle de Charrière, ${ }^{74}$ but this might have been her own specific concern. What we have tried to analyze here is not the women's perspective, ${ }^{75}$ but the way in which (male) discourse about women's authorship establishes links between the written production and its financial rewards. For the cases under discussion it appears that these references make us aware of the roles and attitudes women were supposed to "normally" adopt. Speaking about exceptional women meant of course taking some risk, most particularly in compilations to be used in the

73 "Tel est le drame du génie féminin: il ne peut exister dans le bonheur d'une vie normale", 276 ['my italics, SvD'].

74 See letter 2504 quoted above and notes 2 and 3. Note that Charrière has her place in Larnac's Histoire (169): Philippe Godet, in the meantime, had published his biography, $M a$ dame de Charrière. The very same year 1906 the Revue d'Histoire Littéraire de la France wrote about the book: "These two volumes completely realize Sainte-Beuve's wish. Madame de Charriere now has her monument, the one she deserved" (Ces deux volumes remplissent copieusement le vœu de Sainte-Beuve. Madame de Charrière a son monument, celui qu'elle méritait, 167).

75 The compilers in most cases have not been aware of these: not having read, for instance, the private correspondence of Charrière, they ignored Charrière's wishes as described above. 
context of female education: exceptional women can barely be presented as role models! There had to be a complement in some form of assurance that the women were also "normal".76

Roughly three types of acceptable situations seem to emerge: (1) the woman is presented as married to a man (who may have been attracted by her talents, her beauty or whatever ...) who in fact finances her career; (2) the woman is presented as a financially successful author, making use of the money for helping others (male or female); (3) the woman is presented as meeting with major problems (such as: husband dying), and can be approved for her earning her own living thanks to exceptional talents and/or courage.

Comparison with the treatment of male authors may appear as useful. However, a major difficulty is the absence, for male authors, of representatives of the genre under discussion: the bio-bibliographical compilation according to the tradition initiated by Boccaccio can be seen to compensate for women's absence in "normal" literary historiography ... Besides, we are obviously aware of the "normality" - for the periods concerned - of men possessing and earning money.

\section{Professionalism?}

What about those authors we have not been able to discuss here, because Carton did not mention the financial aspects of their professional lives? Do we have to conclude that they are not professional? And is considering them as not professional a way of dismissing them as important contributors to the literary field?

Isabelle de Charrière might actually be an example which illustrates that this is not true: in spite of her uneasiness that she was - in fact - losing money, in spite also of her absence from most of the compilations discussed above, we can see Jean Larnac being convinced by Philippe Godet: "Madame de Charrière does not deserve the oblivion she is in at present",77 and we know that since 1984 her Oeuvres Complètes are available, in French and (important parts of it) in translations.

76 In the same sense as La Porte assured his female (and male) readers that the women he presented were also "normal", and that "wit is not incompatible with beauty; women whose destiny is to please by physical charms, can also pretend to the glory of talents" (l'esprit n'est point incompatible avec la beauté [...] les femmes, destinées à plaire par les charmes de la figure, peuvent également aspirer à la gloire des talents, I, v). Note that Isabelle de Charrière was described, by Benjamin Constant, as "bizarre"; Valérie Cossy insists upon this in her Isabelle de Charrière. Ecrire pour vivre autrement, Lausanne 2012.

"Madame de Charrière ne mérite pas l'oubli dans lequel on la tient aujourd'hui", 169. 
However, for many women authors who are discussed by the compilers we are left in uncertainty about the way in which they coped with their own potential lack of "normality". In view of a more complete overview we will need to use other recurrent elements of the biographical information (mentioned above on page $\mathrm{xx}$ ), that are in fact equally to be seen as "markers of (ab)normality". In the continuation of this research we will give them particular attention, not restricting our attention to male compilers: just as Christine de Pizan reacted to Boccaccio, we know that Fortunée Briquet, Stéphanie de Genlis and Fanny Mongellaz, for instance, reacted to male discourse about women's authorship. ${ }^{78}$ They certainly need to be included in this discussion.

Briquet was actually one who, as early as 1804 , had written - and published - about Charrière: "her works deserve attention" (ses ouvrages ont du mérite). The male compilers, her followers, discussed above, did not refer to this statement. ${ }^{79}$

\section{Bibliography}

\section{Primary References}

Boudier de Villemert, Pierre-Joseph. 1779. Notice Alphabétique des Femmes Célèbres en France. Amsterdam/Paris: Monory.

Briquet, Fortunée B. 1804. Dictionnaire Historique, Littéraire et Bibliographique des Françaises et des Étrangères Naturalisées en France, connues par leurs Écrits, ou par la Protection qu'elles ont accordée aux Gens de Lettres, depuis l'Établissement de la Monarchie jusqu'à nos Jours; dédié au premier Consul par Mme Fortunée B. Briquet, de la Société des Belles Lettres, et de l'Athénée des Arts de Paris. Paris: Treuttel and Würtz. [Reprint Paris 1997.]

Carton, Henri. 1886. Histoire des Femmes Écrivains de la France. Paris: Dupret.

Coste, Hilarion de. 1647. Les Eloges et les vies des reynes, des princesses, et des dames illustres en pieté, en Courage \& en Doctrine, qui ont fleury de nostre temps, \& du temps de nos Peres. Paris: Sébastien Cramoisy and Gabriel Cramoisy, 2 vols.

Desplantes, F. Pouthier, P. 189o. Les femmes de lettres en France. Rouen: Megard. [Reprint Genève 1970.]

78 Fortunée Briquet, Dictionnaire Historique, Littéraire et Bibliographique des Françaises et des Etrangères Naturalisées en France (1804), Stéphanie-Félicité de Genlis, De l'Influence des Femmes sur la Littérature Française (1811), Fanny Mongellaz, De l'Influence des Femmes sur les Moeurs et sur les Destinées des Nations, sur leurs Familles et la Société (1828).

Which actually was extremely brief and contained an error in the name. 
Genlis, Stéphanie-Félicité de. 1811. De l'influence des femmes sur la littérature française, comme protectrices des lettres et comme auteurs; ou précis de l'histoire des femmes françaises les plus célèbres. Paris: Maradan.

Jacquinet, Paul. 1886. Les femmes de France poètes et prosateurs. Paris: E. Belin.

La Porte, Joseph de. 1769. Histoire Littéraire des Femmes Françoises: ou, Lettres Historiques et Critiques, Contenant un Précis de la Vie et une Analyse Raisonnée des Ouvrage des Femmes qui se sont distinguées dans la Littérature Françoise, par une Société de Gens de Lettres. Paris: Lacombe, 5 vols.

Larnac, Jean. 1929. Histoire de la littérature féminine en France. Paris: Kra.

Mongellaz, Fanny. 1828. De l'influence des femmes sur les mours et sur les destinées des nations, sur leurs familles et la société. Paris: Michaud, 2 vols.

Montferrand, Alfred de. 1843. Les femmes célèbres contemporaines françaises. Paris: Le Bailly.

Most of these compilations can be consulted on the website of the SIEFAR (Société Internationale pour l'Étude des Femmes de l'Ancien Régime; siefar.org). They were used as sources in the NEwW $\mathrm{VR}$ (http://resources.huygens.knaw.nl/womenwriters).

Propiac, Catherine-Joseph-Ferdinand Girard de. 1806. Le Plutarque des jeunes demoiselles, ou Abrégé des vies des femmes illustres de tous les pays, avec des leçons explicatives de leurs actions et de leurs ouvrages. Paris: Gérard, 2 vols.

Riballier, Philibert and Cosson de La Cressonnière, Charlotte-Catherine. 1779. De l'éducation physique et morale des femmes, avec une notice alphabétique de celles qui se sont distinguées dans les différentes carrières des sciences \& des beaux-arts, ou par des talens \& des actions mémorables. Paris: Estienne.

\section{Secondary References}

Charrière, Isabelle de [Belle de Zuylen]. 1979-84. OEuvres Complètes. Ed. Jean-Daniel Candaux et al. Amsterdam: Van Oorschot, 10 vols.

Cossy, Valérie. 2012. Isabelle de Charrière. Ecrire pour vivre autrement. Lausanne: Presses Polytechniques et Universitaires Romandes.

Dijk, Suzan van. 1997. 'L'abbé de La Porte et la Canonisation des Romancières du XVIIIe siècle: Le Cas de Françoise de Graffigny' in Romanistische Zeitschrift für Literaturgeschichte/Cahiers d'histoire des littératures romanes, 21(1-2): 43-54.

Dijk, Suzan van. 2009. 'Présentations et jugements: beauté ou laideur attribuées à des romancières et à leurs personnages féminins' in Moser-Verrey, Monique, Lucie Desjardins and Chantal Turbide (eds.) Le Corps Romanesque. Images et Usages Topiques sous l'Ancien Régime. Québec: Presses de l'Université Laval: 245-266.

Dijk, Suzan van, Anke Gilleir and Alicia Montoya. 2008. 'Before NEWW (New approaches to European Women's Writing). Prolegomena to the Launching of an International Project' in Tulsa Studies in Women's Literature 27(1): 151-57. 
Dijk, Suzan van and Maria Schouten. 2013. 'Numériser les lettres de Belle de Zuylen: Un regard plus précis sur les rapports familiaux' in Cahiers Isabelle de Charrière/Belle de Zuylen Papers 8: 24-44.

Godet, Philippe. 1906. Madame de Charrière et ses amis (1740-1805). Genève: Jullien, 2 vols.

Goldsmith, Elizabeth. 1995. Going Public: Women and Publishing in Early Modern France. Ithaca: Corrnell University Press.

Hoogenboom, Hilde. 2014. 'The Community of Letters and the Nation State: BioBibliographic Compilations as a Transnational Genre around 1700' in Sanz, Amelia, Francesca Scott and Suzan van Dijk (eds) Women Telling Nations. Amsterdam/ New York: Rodopi: 273-92.

Nicholls, James C. (ed.). 1976. Mme Riccoboni's letters to David Hume, David Garrick and sir Robert Liston, 1764-1783. Oxford: The Voltaire Foundation and Taylor Institution (SVEC CXLIX).

Whatley, Janet. 2008. 'The Engaged Life of a Quiet Man: Charles-Emmanuel de Charrière' in Cahiers Isabelle de Charrière / Belle de Zuylen Papers 3: 11-23. 


\title{
Words for Sale: Early Modern Spanish Women's Literary Economy
}

\author{
Nieves Baranda
}

During the early modern period, most Spanish women understood writing as a means of entertainment or self-expression, but a few seventeenth-century female writers built a literary career that gave them prestige as well as financial or economic benefits. These women were proactive in the literary field: they wrote works that were of high commercial interest and could be sold to publishers, composed comedies that were purchased by impresarios to be staged in commercial theatres, received commissions from corporations, and wrote to please patrons who rewarded their work. Besides obtaining direct monetary gains, women writers applied the logic of profit: Luisa Sigea (c. 1522-1560) like other humanists in the first half of the sixteenth century - worked as Latin teacher or secretary for the Portuguese court. Others used literature for utilitarian reasons to promote themselves, their families or their convents. This chapter shows that although there were fewer of them and that they occupied weaker positions, Spanish women writers were active participants of the literary field like their male peers.

I write in accordance with that art which they devised who aspired to the applause of the crowd; for, since the crowd pays for the comedies, it is fitting to talk foolishly to it to satisfy its taste. ${ }^{1}$

Lope de Vega (1562-1635) was the most successful and prolific writer of early modern Spain. He is said to have written over a thousand plays, several thousand poems, and quite a few novels, but more significantly, he can be singled out as one of the first writers to live by his pen. Lope achieved great public recognition, acclaimed as a playwright and as a poet. His life and works were commented upon and hailed and, when he died, he was mourned by a crowd that went out on the streets to honour the writer they considered to be a nature

1 Lope de Vega, Arte Nuevo de hacer comedias [16o9], William T. Brewster tr., New York 1914, 23. This research has been funded by the Spanish Ministry of Economy and Competitiveness, FFI2012-32764 and FFI2015-70548-P BIESES Project. 
monster ("monstruo de la naturaleza"). This success was due to his genius as a writer, but depended also on a cultural system in which his works could be massively disseminated and consumed.

Although a brilliant and sensitive poet, he built his fame as playwright. Permanent theatres initially appeared in Spain, as in other European countries, linked to charitable organizations and by the end of the sixteenth century they were a well-established city feature. Professional troupes appeared and performed actively some time before this period and commercial theater became a new form of entertainment, which attracted paying urban dwellers, contributing to a profitable business. This dramatic tradition dated from the beginning of the sixteenth century and had developed in various forms, as it was capable of adapting to diverse audiences and situations. The increasingly large audiences of permanent theatres played a decisive role in this development as experiments and formulae were tried in order to please them. This was not an easy task, as spectators were heterogeneous due to the attraction of the corrales (theatres) to all members of society. Among a good number of remarkable playwrights (Cervantes being one of them), it was Lope de Vega who devised the essential features of a new genre, the comedia. This genre was to be the basis of Spanish theatre for nearly two hundred years and made Lope the most popular writer of the time. His talent for creating varied plots, mixing situations and characters, as well as his quick response to the demands of audiences and his ability to write plays in a very short period of time ensured his success from the beginning of his career. It also allowed him to make his living from writing by responding to what audiences and theatre companies required. ${ }^{2}$ Furthermore, Lope paid attention to the possibilities offered by the book market and wrote works to please the reading public: novels, lyric and religious poetry and fashionable, miscellaneous books. However, printers were the first to realize plays could be marketable in print when a volume collecting six plays by "Lope de Vega and other playwrights" was published in $1603 .{ }^{3}$ Publishers did not need Lope's permission to print his works as he had lost the property rights when he sold them to the autores ${ }^{4}$ to be staged. His printed plays were organized in partes (parts), volumes that contained between six to twelve plays and were a great

2 A general survey on Spanish theatre in Historia del teatro español, ed. Javier Huerta Calvo, dir., Madrid 2003, I, 611-77. There are plenty of studies on the origin, see for example Jesús Cañas Murillo, "Lope de Vega, Alba de Tormes y la formación de la comedia", Anuario de Lope de Vega, VI (2000), 75-92.

3 Lisboa: Pedro Craesbeck, 16o3; and Madrid: Pedro de Madrigal, 1603.

4 Autor at the time and in a theatrical context referred to the impresario who staged the plays. The Spanish word today means 'author'. 
success. These did not benefit authors, but publishers, who supplied new editions to the market regardless of the playwrights' complaints about the quality of the printed texts and heedless of the fact that the writer received no profit at all. Only in 1617 did Lope gain control of these compilations when he was able to take over the publishing business of his plays, although by then the compilations were already on the ninth volume, and he could not stop printers from producing his works. ${ }^{5}$ Earning his living by writing for a consumer public was not his only literary aim, and Lope also attempted to gain official positions either by pleasing nobles or by flattering the crown. This task relied partly on his fame and visibility as a playwright and partly on the works desired. Patrons expected genealogic plays, epic poems, poetry, or other works on commission. The material value of this production fluctuated based on whether the patronage resulted in a paid permanent post (which Lope never received), in a stipend (if the work was ordered by an aristocrat or an institution, such as the city council or a religious order), or in nothing at all. ${ }^{6}$

Lope de Vega's literary career shows that, by the turn of the seventeenth century, the Spanish literary system offered at least three ways to obtain benefits from work, none of which ruled out the others. Moreover, the professional writer had to compete in all facets in order to be really successful. Firstly, playwrights could sell their plays to theatrical company directors (autores), who often commissioned them, too, and were entitled to alter, reuse and resell them. Consumers decided what the production value was, and so the literary commodity responded to audience tastes to satisfy them. Secondly, although the public was ready to buy printed books, only some genres or topics were considered successful. These included novels and plays which by dint of their ill-matched copyright laws, typically provided benefits only to publishers and rarely to authors. In fact, in both cases, writers' revenues, when dependent on the market and consumers' decisions, were usually obtained by selling the work to a third party that took the risk, either the autor of the play or the publisher, as guarantees on shared benefits were difficult to obtain. The third and most common possibility was to remain loyal to the tradition of patronage,

5 He supervised volumes nine to twenty, and when he died others were ready to be published by his heirs: in all up to twenty-four were printed. Jaime Moll "Tercera parte de las comedias de Lope de Vega Carpio y otros autores", falsificación sevillana", Revista de Archivos, Bibliotecas y Museos, 77 (1974), 619-26; Germán Vega García-Luengos, "La transmisión del teatro en el siglo XVII", in Huerta Calvo ed., Historia del teatro español, t. I., 1289-1320.

6 Elizabeth R. Wright, Pilgrimage to Patronage. Lope de Vega and the Court of Philip III, 15981621, Lewisburg 2001, 134-39. 
which continued for centuries and modeled writers' careers and works dependent on the power field as described in Bourdieu's theories. ${ }^{7}$

\title{
Ana Caro's Professional Career
}

\begin{abstract}
In Seville, on the 2oth of May, 1645. In the dwellings of his lordship Asistente [mayor] met the Committee on the Holy Sacrament feast for this year of 1645 and some autos [religious plays] were considered to be put on stage on the feast day written by Ana Caro. Once seen by the Committee it was decided to order a payment of 300 reales for her work, having made and auto for the feast. ${ }^{8}$
\end{abstract}

Ana Caro, active between 1628 and 1645, understood the logic of literary profit and was paid by the city council and certain aristocrats. Little is known about her life, but there is evidence to show that she took all expected steps to transform her literary talents into a successful career and managed to do so to the same extent as her male writer peers. Without question, she is the most outstanding example of a Spanish professional woman writer of the period and her success can be traced by her works' dedications.

Although there are no records, Caro was supposedly born in Seville, but may also have been native to a village nearby. Her date of birth is unknown, so it is difficult to ascertain how old she was in 1628 , when her first work was published. It is not unreasonable to believe she was born at the turn of the century, or perhaps a few years earlier, as Spanish women writers of this period tended not to publish in their youth.

7 Pierre Bourdieu, Las reglas del arte. Génesis y estructura del campo literario, Barcelona 1995, 318-52. The methodology has partly been applied to early modern Spain by Donald GilbertSantamaría, Writers on the Market. Consuming Literature in Early Seventeenth-Century Spain, Lewisburg 2005, or Enrique García Santo-Tomás, “Lope, ventrílocuo de Lope: Capital social, capital cultural y estrategia literaria en las Rimas de Tome de Burguillos (1634)", Bulletin of Spanish Studies, 77/ 4 (2000), 287-303, among others.

8 "En la ciudad de Sevilla en 20 días del mes de mayo de 1645 año. En las casas de morada de su señoría Asistente, se juntó la Comisión de la fiesta del Santísimo Sacramento de este presente año de 45. En la cual se vieron unos autos para representar el día de la fiesta, hechos por Ana Caro y los cuales vistos por la Comisión, fue acordado que se le libren 300 reales por el trabajo de aver hecho un auto para esta fiesta", Lola Luna, Ana Caro, una escritora profesional del Siglo de Oro. Vida y obra [Ph.D. Thesis], Universidad de Sevilla, 1992, 21. The auto or auto sacramental was a dramatic genre with an allegorical plot dealing with some aspect of the mystery of the holy Eucharist performed during the Corpus Christi celebrations. For more details see below. 
Her first printed work, Relación en que se da cuenta de las grandísimas fiestas que en el convento de nuestro padre san Francisco de la ciudad de Sevilla se han hecho a los santos mártires del Japón ${ }^{9}$ proves that by 1628 she had already managed to find protectors in the city. From the very beginning she declares the poem to be an object of courtly exchange for a nobleman's favour: "Receive, sir Juan de Elossidieta, this noisy speech [sic] under your shelter ... you may well say that has been a ruse to rely on you, that is expensive [caro] for you as I have wanted something worthless to nearly match the highest grandeur." ${ }^{10}$ This first printed work meets the requirements of an eulogistic genre exchanging money for praise. The poet's obligation is to present an idealised image of the patron and the city authorities in several respects: religion, wealth, generosity, courage and loyalty. Expensive festivities organised by public institutions were crucial in transmitting ideology, and maintaining social structures and cohesion. During celebrations, social groups displayed their power, authority and prestige through their appearance and the place they occupied, a demonstration that served to keep hierarchal and corporate order. Celebrations were made for showing adherence to public religious or political values and commitment to the Catholic Church and the Crown. All of them participated, but a prominent role was given to the elites, to legitimise their status before the commoners and to exhibit their position and aspirations to other groups or town institutions. However, public events were limited in space and time and other secondary forms of dissemination were needed to increase and enhance their effectiveness. Printed chronicles, either booklets or large books including speeches, sermons, poetry and so on, were used to reach a wider audience and extend the exhibitionism of public events. The image of the city, its wealth, the courage of the elites (the most prominent groups or noblemen) and their allegiance to the Crown and Kingdom were disseminated as an ideological agenda amplified and broadened to a national or international scale; a local event turned into a means of promotion.11

$9 \quad$ Report on the huge Feasts our father Saint Francis Convent of Seville has celebrated for the Martyrs in Japan. (Sevilla 1628); edition by Francisco López Estrada, "La relación de las fiestas por los mártires del Japón, de doña Ana Caro de Mallén (Sevilla), 1628” in Librohomenaje a Antonio Pérez Gómez, Cieza 1978, II, 161.

10 "Recibid señor Juan de Elossidieta/este ruido discurso en vuestro amparo/.../Podéis decir muy bien que ha sido treta/el valerme de vos, que os cuesta Caro,/pues he querido lo que nada vale/que a la mayor grandeza casi iguale", Luna, Ana Caro, 319. The writer makes a pun using her family name, Caro, which means expensive.

11 José Antonio Maravall, La cultura del barroco. Análisis de una estructura histórica, Barcelona 1981, 487-98; Christine Kaplisch-Zuber, "Rituals publics et pouvoir d'état" in Culture et ideologie dans la genese de l'état moderne, Rome 1985, 136-53; Pedro Gómez García, "Hipótesis sobre la estructura y función de las fiestas", in La fiesta, la ceremonia, el rito, 
Relaciones or short chronicles were used to represent parties and their positions in the politics of the Kingdom, but they also played an important role on a local level as accounts, which helped form a collective memory for the local community. Various social agents were interested in controlling narratives to ensure they worked in their own interest: something that could be achieved by commissioning a relación, which exalted adequate values and people. Caro's first printed work is one such short chronicle, and depicts an idealised image of a celebration. It is not a freely inspired poem, but a commissioned text that must obey certain rules of rhetoric and comply with a maximum length for the printed format. ${ }^{12}$ The poem is written in hendecasyllable verses laid out in 48 stanzas in octava rima, and uses a learned style to dignify the topic adorned by a lavish rhetoric with plenty of adjectives. Each subject's importance is commensurate with its length: two stanzas for the dedication, four on the Franciscan martyrs in Japan and 41 describing the celebrations. In this long section, church and city adornments are depicted, some famous preachers' and noblemen's names are mentioned, but narration focuses on the deeds of a group of Basque gentlemen. At least twelve stanzas, including the last one, are devoted to this group. They talk about their fame as glorious heroes for which they are granted prominent positions. The work is dedicated to an unknown Don Juan de Elossidieta, whose surname suggests he was of Basque origin. Considering he is not directly mentioned in the celebrations, but the "noblemen from Guipúzcoa and Biscay"13 are praised, it can be guessed that the payment hinted by Caro's words was meant to please the national group Elossidieta belonged to, as Caro's poem flatters Basques for their military condition. People from the Basque region were an important group in seventeenth-century Seville. They traded in gold and silver from the American colonies and were businessmen and bankers closely linked to institutional powers, where they often held office. Receiving such commission proves Caro was a respected writer with connections to the city elites. Otherwise - in a city where many celebrated writers already lived, ready to take up a likely well-paid assignment - she would not have been entrusted with the task.

Granada 1999, 51-62. An excellent overview in Teresa Ferrer Valls, "La fiesta en el Siglo de Oro: en los márgenes de la ilusión teatral", Teatro y fiesta del Siglo de Oro en tierras europeas de los Austrias, Madrid 2003, 27-37.

12 The Relación is 16 pages long in an octavo edition. See on women writers' Relaciones and pamphlets M a Carmen Marín Pina, "Public Poetry", in The Routledge Companion to Early Modern Spanish Women Writers, London/ New York 2017, 205-18.

13 "nobles de Guipúscua y de Vizcaya", Francisco López Estrada, "Costumbres sevillanas: el poema sobre la Fiesta y Octava celebradas con motivo de los sucesos de Flandes en la Iglesia de San Miguel (1635), por Ana Caro de Mallén", Archivo Hispalense, LXvi/203 (1983), 165, line 193 . 
Caro's search for patrons seems to trace an ascending path when evidence taken from the dedications in her printed works is followed. Leaving aside the poem published in 1633 that extols a small raid for loot in enemy territory, ${ }^{14}$ another, dated 1635 , is dedicated to the Countess of Salvatierra. In 1637, each of the three parts of a short work is allocated to different dedicatees: Agustina Spinola, wife of a royal banker, the Count-Duke of Olivares, King Philip IV's Prime Minister and favourite, and the city of Madrid. The Grandiosa Vitoria que alcançó de los moros de Tetuán (Grand Victory Over the Moors of Tetouan) is dedicated to its hero, Jorge de Mendoça y Piçaña, the Portuguese General and Governor of Ceuta who most probably ordered the relación to draw attention to and magnify his evidently small victory on the battlefield. The Countess of Salvatierra, Leonor de Luna Enríquez, was married to the Sevillian mayor who had organised celebrations described in the Relación de la grandiosa fiesta y octava que en la iglesia parroquial de el glorioso san Miguel de la ciudad de Sevilla hizo don García Sarmiento de Sotomayor, Conde de Salvatierra. ${ }^{15}$ The celebration's object was an event that occurred during the Thirty Years War, which was thoroughly disseminated by sermons and printed propaganda in order to ideologically stir up the population. As above, Ana Caro's long poem narrates the episode and denigrates the heretics' wickedness in only 130 verses out of 873 (approximately 15 per cent). In the two other parts, the incident is mentioned mostly amongst descriptions of festivities, the Church, decorations, processions and fireworks in artificial and exalting vocabulary. Few names are mentioned in the poem: the Counts' of Salvatierra and the preachers'. Seville nobility is referred to as a group (line 705), but lines 202 through 221 deal with the Counts. Strategically placed at the end, more than 100 verses praise the virtues of the asistente comparing him to the archangel St. Michael: one in heaven and the other on Earth. It is hard to establish if the relación was commissioned first or if Caro wrote it for a coterie and published it to seek a reward that would end in payment and a printed broadsheet with the text. Ana Caro's strategy to approach the city's most powerful man searching for a profitable patronage is clear. ${ }^{16}$ The four preliminary poems in the booklet praise Caro as

14 Edition by Francisco López Estrada, "La frontera allende el mar: el romance por la victoria de Tetuán (1633) de Ana Caro de Mallén” in Homenaje a José Manuel Blecua, ofrecido por sus discípulos, colegas y amigos. Madrid 1983, 337-46.

15 Chronicle of the grand celebration and octave that in the parish church of the glorious Saint Michael of Seville was done by García Sarmiento de Sotomayor, Count of Salvatierra, Seville 1635 .

16 Carlos M. Gutiérrez, La espada, el rayo y la pluma. Quevedo y los campos literario y de poder, West Lafayette, Ind. 2005, 157, makes a difference between commissioned works and the others: "the others usually try to attune to what is believed to be a cultural expectation 
an author, festivities narrator and "Seville muse", and were useful for that purpose as it is implied that, just as the Count of Salvatierra occupies the celebrations summit, she as a poet matches his position in the literary field. Poets used eulogic texts to fashion their own authorial image in order to obtain social recognition, ${ }^{17}$ especially as patrons desired association with prestigious writers, who showed their worth by using a learned rhetoric (as in Caro's poem) and had achieved recognition among their peers. This relación might have been a means to draw the attention of the Count of Salvatierra, who being appointed asistente (mayor) of the city, had arrived in Seville the year before.

Ana Caro was not prominent in the urban literary circles at that time. The eulogistic preliminary poems' authors in the 1635 booklet were of little or no consequence in the Seville Parnassus at the time, meaning she did not belong to the city's main coteries yet. These links developed around those years. The Seville poet and playwright, Luis Vélez de Guevara, high servant to King Philip IV, describes a literary academy held about 1637 in the house of the Count of Salvatierra (mayor between 1634 and 1641), where Ana Caro, "Seville tenth muse", read a poem in honour of Lope de Vega. ${ }^{18}$ Other prominent writers mention her in those years: in approximately 1637 , María de Zayas asked her for a poem to be included in the paratexts of her Novelas amorosasy ejemplares (Amorous and Exemplary Novels) edition; Alfonso de Batres mentions Caro as participating in the Academy of Buen Retiro in Madrid in 1638; and in 1644, Alonso de Castillo Solórzano depicts her accompanying María de Zayas in the same city ${ }^{19}$ Citations show that her value in the literary society increased and

horizon in the power field. That is to say some works adopt certain twist more because of the active principle of cultural agents, good judges of the possibilities, than because of requirements (which existed)" "'lo que suele pretender el resto de las obras es concordar con lo que se percibe como un horizonte de expectativas culturales del campo del poder. Es decir, que algunas obras adquieren un sesgo determinado más por principio activo de los agentes culturales, bien conocedores del espacio de posibilidades, que por imposiciones (que las había)"). Ana Caro, lacking direct commissions, would be in the second group looking for immediate profit if no other options of paid engagement were open. $\mathrm{M}^{\mathrm{a}}$ Grazia Profetti, "Poder y estrategias editoriales de Lope de Vega", in Représentation, écriture et povoir en Espagne a l'epoque de Philippe III (1598-1621), eds M.G. Profeti and A. Redondo, Firenze 1999, 87-105.

18 El diablo cojuelo [1641] eds Ángel R. Fernández and Ignacio Arellano, Madrid 1988, 211. If the internal chronology of the story is considered to be right, the described literary meeting had to be held in 1637 or later, because the character recites a poem written for a celebration in the court that year, see Inmaculada Osuna, "Literary Academies and Poetic Tournaments", in The Routledge Research Companion to Early Modern Spanish Women Writers, eds N. Baranda and A.J. Cruz, Oxon/ New York 2018, 156.

19 "[Zayas] is accompanied by Dona Ana Caro Mallén, lady from our Seville, to whom no less praise is due, because with her sweet and thoughtful verses suspends and delights all who 
that she improved her position. Well-known writers living in Madrid, and particularly the court - the place where everyone looked for fame - were aware of her literary production, which meant Caro's fame had traversed the limited Andalusian border to touch the sought-after Parnassus of her time.

These mentions went together with a rise in her patrons' rank, as she reached the Count-Duke of Olivares, King Philip's IV favourite. Caro arrived in Madrid early in 1637 and spent part of the year there. The Count-Duke of Olivares had resided in Seville between 1607 and 1615, where he was a patron of writers, and Caro was likely connected to the court circle that led her to the heart of power. When called to the royal court, some patronised writers followed the Count-Duke; for example, the poet, Francisco de Rioja, his secretary and librarian, Francisco de Calatayud, his official biographer and Juan Antonio de Vera, Count of La Roca, ambassador and author of his panegyric. ${ }^{20}$ Caro's connections to this group may explain why she moved to Madrid and account for her success in publishing the Contexto de las reales fiestas que se hicieron en el palacio del Buen Retiro. A la coronación del rey de Romanos y entrada en Madrid de la señora princesa de Cariñán, en tres discursos. ${ }^{21}$ Making the most of the possibilities of patronage, the book has three parts and three different dedications: the first to Agustina Espinola, banker Carlos Strata's wife, ${ }^{22}$ the second to the Count-Duke of Olivares and the third to the city of Madrid. The

hear and read them, as proved by the ones she wrote to the last carnival festivities held in the Buen Retiro ... She depicts everything with as much ornament and decorum as such a great celebration deserved. ..." (“Acompáñale en Madrid doña Ana Caro de Mallén, dama de nuestra Sevilla, a quien se deben no menores alabanzas, pues con sus dulces y bien pensados versos suspende y deleita a quien los oye y lee; esto dirán bien los que ha escrito a toda la fiesta que estas carnestolendas se hizo en el Buen Retiro ... pues trata della con tanta gala y decoro como mereció tan gran fiesta. ..."), Alonso de Castillo Solórzano, La garduña de Sevilla y anzuelo de las bolsas, ed. Federico Ruiz Morcuende, Madrid 1972, 67. On Ana Caro and the social literary world, see Alicia R. Zuese, "Ana Caro and the Literary Academies of Seventeenth-Century Spain", in Women's Literacy in Early Modern Spain and the New World, eds Anne J. Cruz and Rosilie Hernández, Hampshire/Burlington 2011, 191-208.

$20 \quad$ Poder y saber. Bibliotecas y bibliofilia en la época del conde-duque de Olivares, Madrid 2011. John H. Elliot, The Count-Duke of Olivares. The Statesman in an Age of Decline, New Haven 1986, 21-30; José Luis Colomer, "El conde de la Roca y el marqués Virgilio Malvezzi. Dos diplomáticos panegiristas del Conde Duque de Olivares", in Por discreto y por amigo. Mélanges offerts à Jean Canavaggio, eds Christophe Couderec et Benoit Pellistrandi, Madrid 2005, 513-34; and Gutiérrez, La espada, 150-56.

21 Chronicle of the royal festivities done in the Buen Retiro Palace. To the coronation of the Romans King and the entrance of her ladyship the Princess of Carignan in Madrid, in three discourses, Madrid 1637, ed. Lola Luna in Bieses: http://www.bieses.net/ana-caro-mallencontexto-de-las-reales-fiestas/

22 According to Elliot, The Count-Duke, 503, he was "one of the most flamboyant of the Genoese bankers" and had lent the Spanish Crown the fabulous sum of 2,150,00o escudos in 
preface to the reader and the dedication to the Count-Duke suggest that Caro took the initiative to compose the work and circulate the manuscript until she was asked to have it printed. Manuscript and printed poetry circulation were concurrent channels, and success with handwritten copies could lead to the press, although some changes for the wider reading public could be necessary for texts with a strong political subject. Caro states at the beginning:

it is badly reasoned because it was written not to be published and with a different matter, as can be realised by my reluctance to put it to print, I do it now changing the beginning, so it will be less common ... [emphasis added] ${ }^{23}$

Only one version of the work remains, so it is impossible to know how it was changed, but reading the other dedications carefully, it seems that it might have been more than the beginning. When addressing the Count-Duke, Caro states the work was written for Seville ("The Relación de las fiestas reales del Buen Retiro I wrote to Seville and your excellency saw, I was asked to put to print ..."), ${ }^{24}$ but that it is not in the text. The third part is also dedicated to the city of Madrid and the text says in an apologetic tone: "and so, although late, I offer to your Lordship this little part of my great love [emphasis added, $\mathrm{NB}]$ ". 25 These differences suggest that after circulating the manuscripts she was asked to prepare a new version to be printed. She was to leave the relaciones dedicated to the banker's wife and the minister untouched, and had to add a third one dedicated to Madrid, perhaps to replace the one she had written for Seville, hence the excuse of having done it late. Documents show the city lavishly paid 100 ducats to the author. ${ }^{26}$ Each city council nobleman is mentioned

1635. His wife, Agustina Spinola, belonged to another of those wealthy Genoese families so Caro was aiming at the acme of the social pyramid.

23 "lo mal razonado de él es haberse hecho sin intención de publicarlo y con diferente asunto, como se conocerá en la remisión que he tenido para darle a la estampa, hágolo ya, mudándole el principio, causa de que vaya menos corriente...", Caro, Contexto, n.p., discourse I.

24 "La Relación de las fiestas reales del Buen Retiro que escribí a Sevilla y vuestra excelencia vio, me han pedido que imprima...", Caro, Contexto, n.p., discourse II.

25 "y así, aunque tarde, ofrezco a vuestra señoría esta pequeña parte de mi mucha afición", Caro, Contexto, n.p., discourse inI.

26 "Payment letter to dona Ana Caro de Mallén, 100 ducats for the Relación de las fiestas. Madrid, 3oth, August, 1638. Before Pedro de Castro" "Carta de pago de Doña Ana Caro de Mallén, de 100 ducados por la Relación de las fiestas. Madrid, 30 de Agosto de 1638. Ante Pedro de Castro") (Cristóbal Pérez Pastor, Noticias y documentos relativos a la historia y literatura españolas, Madrid 1910, I, 97). To get an idea of how much it was, the same amount was paid to Velázquez in 1629 for the picture The Triumph of Bacchus, see José Gudiol, Velázquez, 1599-1660: historia de su vida, catálogo de su obra, estudio de la evolución de su técnica, Barcelona 1973, 87. 
by name and surname and their contribution to the celebrations depicted with flattering images, which correspond to the expected eulogistic tone of these poems. ${ }^{27}$ It is more revealing that every preface includes the word generosidad (generosity) an ambiguous term meaning mostly 'from high lineage', but also 'lavish' in modern Spanish: "the noble generosity of Carlos Strata"; the CountDuke is a "generous shelter"; and she pleads the city "being so generous" to receive her present. ${ }^{28}$ Courtesy and praise barely hide the author's anxiety for the economic benefit of a piece that was made for exactly that: to meet the expectations of a select few, who paid a high price to feel flattered and be portrayed in ennobling lights. It was one of the most common modes of exchange between writers and powerful patrons and Ana Caro knew well how to manage this. Nevertheless, there were other possibilities and she did not ignore emerging economic forces that sustained a market not yet independent or strong enough to free the writer of servitude from the ruling class, but already interesting enough to draw her attention and dependency. Addressing the public, she boldly states in the preface: "I beg you to censor it as yours and buy it as alien, as this way if you are not happy I shall be paid". ${ }^{29}$ The Contexto de las reales fiestas (Account of the Royal Festivities) is not only the biggest step in Caro's progression under patronage, as she managed to touch with her fingertips the Kingdom's acme of political and financial power, but unlike her previous relaciones, this one proves her awareness of the commercial value of writing and thus her work caters to two possible means of literary profit.

Caro wrote plays too, possibly the most marketable genre of the time, and succeeded in making profit in more than one respect. In the document previously quoted, a commission of Seville's city council ordered her to be paid for having written a play for the Corpus Christi festivities which were among the most

27 The dedication to Agustina Spínola, as the previous one to the Countess of Salvatierra, is in fact to her husband. Texts mention wives, but refer to their husbands with even longer praise. Including the spouse was not an obligation in dedications to women, see Nieves Baranda, "Women's Reading Habits: Book Dedications to Female Patrons in Early Modern Spain”, in Women's Literacy, eds Cruz and Hernandez, 19-39.

28 The semantic field of generous ('lavish') is especially significant in the dedication to Agustina Spinola, using expressions as clear as "her more than liberal spirit" ("el más que liberal ánimo suyo") or even in the hardly veiled statement: "I assure my wit rich gains" ("aseguro a mi ingenio ricas medras"), Caro, Contexto, n.p., discourse I.

29 "suplícote le censures como tuyo y le compres como ajeno, que con esto, si tú no contento, yo quedaré pagada", Caro, Contexto, n.p., discourse I. Printing and the market were valued differently depending on the literary system. On the Spanish literary market, see GilbertSantamaría, Writers on the Market, 13-20. According to Kim Walker, Women Writers of the English Renaissance, New York 1996, 146, in England women avoided writing openly for a financial gain as it could be seen as prostitution (see also the introduction to this volume). 
important of the religious calendar because they extolled the sacrament of the Eucharist that had become a hallmark of Catholic identity after Trent. These festivities took place in the spring and cities, according to their wealth, organised all kinds of celebrations, including street adornment, music, dances, fireworks, religious processions and the staging of public plays. Religious theatre was one of the highlights of the program. Unlike the plays staged in corrales (public theatres for a paying audience), these Corpus Christi allegorical representations were staged on carts in selected places of the municipality because the city council hired the companies and could even commission the plays. Between 1641 and 1645, the city of Seville paid Ana Caro for three different autos that were staged during the Corpus Christi feast. ${ }^{30}$ These payments illustrate the commercial nature of her work, but also her fame. Literary renown was essential to get an auto on stage, but in order to be well paid, connections with local authorities were necessary, too. There remains no evidence of municipal payments to Caro before her journey to Madrid, which may be due to archival losses, but could also suggest that her visit to the court there was the basis of her increased prestige upon her return to Seville. This hypothesis cannot be proved, but would be consistent with a growing career where decisions are made considering profit. The Corpus Christi auto payment offered her an income to reinforce her economic independence and literary value so it can be considered one more step forward in her professional progress.

Ana Caro did not just write autos, but commercial plays for public corrales. ${ }^{31}$ Although she may have written many more works, only two comedies remain: El conde Partinuplés (The Count Partonopeus) and Valor, agravio y mujer (Courage, Affront, and Woman). There are manuscript copies and prints of these plays, so likely they were successful, sold to an autor (theater manager) and staged. ${ }^{32}$ Commercial theatre in the late sixteenth century, since the consolidation of public success developed on a thriving market based on printing plays, as previously mentioned, but playrwrights did not receive the benefits of this printed trade because they lost all rights in the work when sold for being performed. Impresarios obtained an additional benefit by selling the script to

30 José Sánchez Arjona, Noticias referentes a los anales del teatro en Sevilla, desde Lope de Rueda hasta fines del siglo XVII, Sevilla 1898, 341-59. She was paid 300 reales for each of them. The same amount is paid for a month's work to the manager of a weapons factory in Tolosa (Navarra), Ignacio M. Carrión Arregui, "El trabajo en una manufactura real del siglo XVII: los armeros de la Armería de Tolosa”, Vasconia, 30 (2000), 79. I am indebted to Teresa Ferrer Valls for the questions she answered on this writer.

31 Corral de comedias, literally a "theatrical courtyard", was the open-air enclosed rectangular courtyard typical of a block of houses used for staging dramas. They began as occasional sites, but the structure was maintained in permanent theatres. Valor, agravio y mujer, ed. Lola Luna, Madrid 1993; and El conde Partinuplés, Kassel 1993. 
printers who were interested in publishing successful works, so a printed play is usually the result of several sale contracts; the first of them organised by the playwright. ${ }^{33}$ Caro's El conde Partinuplés is included in Laurel de comedias, cuarta parte, a compilation of several plays (1653) and Valor, agravio y mujer was published twice as a suelta (a booklet or an offprint), which functioned to disseminate theatre by producing thousands of copies during the seventeenth and eighteenth centuries.

\section{María de Zayas: Novels to be Purchased}

Nowadays shines and stands out with joyous laurels Dona Maria de Zayas y Sotomayor's wit, who has rightfully earned the title of Sybil of Madrid, acquired by her admirable verses for her fortunate wit and great prudence, having given to print a book of ten novels that are ten wonders for those who write this genre ... She is accompanied by Dona Ana Caro Mallén, lady from our Seville, to whom no less praise is due ..." ${ }^{34}$

On her trip to Madrid in 1637, Caro met María de Zayas, the most famous female writer in the court at the time. ${ }^{35}$ Unfortunately, little can be said of her life and literary relations, aside from citations and conclusions derived from her works. Nevertheless, it is clear that she deliberately sought to be visible in the literary world of Madrid, and put in every effort to publish and reach revenues. María de Zayas began to be noted in Madrid's coteries in the twenties. In 1621, 1622, 1624 and 1626, some of her poems were published in the preliminary parts of other authors' works published in Madrid and, in 1629, in

33 Historia del teatro español, ed. Huerta Calvo, I, 1289-93 and 1305-10. Women were quite active in theatre, see Teresa Ferrer, "La mujer sobre el tablado en el siglo XVII: de actriz a autora", in Damas en el tablado. Actas de las XXXIJornadas Internacionales de teatro clásico de Almagro (1-3 de julio de 2008), Almagro 2009, 83-100, an activity that has been compared to England; Iván Cañadas, Public Theater in Golden Age Madrid and Tudor-Stuart London: Class, Gender and Festive Community, Aldershot/Burlington 2005.

34 "en estos tiempos luce y campea con felices lauros el ingenio de doña María de Zayas y Sotomayor, que con justo título ha merecido el nombre de Sibila de Madrid, adquirido por sus admirables versos, por su felice ingenio y gran prudencia, habiendo sacado de la estampa un libro de diez novelas que son diez asombros para los que escriben deste género ...[...] Acompáñale en Madrid doña Ana Caro de Mallén, dama de nuestra Sevilla, a quien se deben no menores alabanzas ...", Castillo Solórzano, La garduña, 66.

35 On María de Zayas and her relationship to Ana Caro, see Mercedes Maroto Camino, "Maria de Zayas and Ana Caro: The Space of Woman's Solidarity in the Spanish Golden Age", Hispanic Review, 67 (1999), 1-16. 
the Laurel de Apolo (Laurel of Apollo) Lope de Vega considered her part of the literary coteries. Lope's work is a Parnassus where he names and appraises many contemporary writers who had some name: "immortal Maria de Zayas [...] because her vividly clear wit,/is so unique and rare/she alone could give fame to the city of Madrid". ${ }^{36}$ Citations prove her friends were some of Madrid's best-known writers, involved in active literary coteries attentive to the commercial advantages of publishing. This group included poets, playwrights and novelists interested in marketing literature. For instance, Juan Pérez de Montalbán, son of a publisher, the Portuguese Miguel Botelho de Carvalho, who published in Rouen Violante do Céu's Rimas (1646) and of course, Lope de Vega. ${ }^{37}$ Commendatory poems of some of them mention María de Zayas' first published collection of novels, Novelas amorosas y ejemplares, reinforcing that she belonged to a particular literary group and had power within it. ${ }^{38}$ The focus of these commendatory poems on the writer is significant, and there are several voices involved. Her friends praise her as laureated poet, and Ana Caro, perhaps because of a gender consciousness, considers her a glory for Spain and places her as descending from illustrious classical writers, such as Sappho or Pola Argentaria. The prose preface by a Desapasionado provides evidence. Choosing "dispassionate" as a nickname stresses it is an objective voice, ${ }^{39}$ but the text presents inordinate praise: Zayas' wit as a woman excels all the rest, her fame has been reckoned and acclaimed by the court, which implies she is commended by the best. Moreover, her works combine wit and morality, two attractive features with a socially educational message. This advertising aims to convince the reader that the book must be owned, not only read, but it must be paid for: "and not borrowed but purchased with your own money; no matter what it costs, it will be well spent money".40

Zaya's preface to the reader has been repeatedly studied for it is dependent on the Querelle des femmes tradition, defending women's right to study and

36 Félix Lope de Vega Carpio, Laurel de Apolo, ed. Christian Giaffreda, Firenze 2002, 258.

37 María Dolores Martos Pérez, "De musas a poetas: escritoras y enunciación canonizadora en la obra de Lope de Vega", Arte nuevo 4 (2017), 787-847.

38 Zaragoza 1637. Commendatory poems by Alonso de Castillo Solórzano, María Caro de Mallén, Juan Pérez de Montalbán, Francisco de Aguirre Vaca. The edition was published in Zaragoza because printing novels or plays was forbidden in Castile between 1625 and 1634 so some writers travelled to Aragon to publish their works as there were different laws. Nonetheless, Zayas carried the poems with her manuscript work as writers were from Madrid.

39 Some translations use "objective reader".

40 "no pidiéndolo prestado, sino costándote tu dinero; que aunque fuese mucho le darás por bien empleado", María de Zayas, The Enchantments of Love: Amorous and Exemplary Novels, tr. H. Patsy Boyer, Berkeley 199o, http://ark.cdlib.org/ark:/1303o/ft638nb3jd/ 
write, but there are also some striking statements about the commercial value of writing. ${ }^{41}$ Firstly, the importance given to the printing-press as a way of measuring a book's quality: "until the writings enjoy the lead, letters have no true value and firmness". ${ }^{2}$ Here Zayas implicitly states that the value of literary work does not reside in the judgments of writers and patrons, but on the decision of the market, as only through extensive dissemination to the public can quality be tested. Moreover, it does not depend on positive reviews, but on something as material as money: the revenues obtained in exchange for the literary product prove its worth. The process by which a writer reaches that point is synthetically described thus:

From this inclination [to books] came information, and from the information good taste, and from this the writing of poetry, and then the writing of these novellas, perhaps because they seemed easier or more interesting to write. Books that aren't erudite can be good if they have a good subject, while many works filled with subtlety are offered for sale but never bought because the subject is unimportant or not pleasing. ${ }^{43}$

Zayas did not care that her novels were criticised as too easy or too popular, because as she points out there are many highbrow books for sale, which remain ignored. Her aim is clearly commercial, writing for selling, and she agrees with Lope de Vega: "for, since the crowd pays for the comedies, it is fitting to talk foolishly to them to satisfy their taste". Zayas seems to understand that being an author is having one's name printed on the book's title page, and she shares the groundbreaking ideas of her coterie, introduced by Lope de Vega and accepted by those who understand that pleasing readers ("easier or more interesting") triggers a satisfying exchange of literary product for money ${ }^{44}$ It is not possible to infer that Zayas, being a woman, was in search of a market,

41 Many critical studies could be mentioned but Yolanda Gamboa, "María de Zayas, or Memory Chains and the Education of a Learned Woman", in Women's Literacy, eds Cruz and Hernández, 209-24, sums up most of them and she adopts a point of view useful for our arguments.

42 "hasta que los escritos se gozan de las letras de plomo no tienen valor cierto ni firmeza", Zayas, The Enchantments, cit. ed.

43 "Desta inclinación nació la noticia, de la noticia el buen gusto, y de todo hacer versos hasta escribir estas novelas o por ser asunto más fácil o más apetitoso, que muchos libros sin erudición suelen parecer bien en fe del sujeto y otros llenos de sutileza se venden, pero no se compran, porque la materia no es importante o es desabrida", Zayas, The Enchantments, cit. ed.

44 Isabel Enciso Alonso-Muñumer, "Nobleza y mecenazgo en la época de Cervantes", Anales Cervantinos, 40 (2008), 47-61. 
although it might have been so, considering that women writers had limited expectations in a patronage system that had no jobs for them. In a competitive environment that excluded them from certain potential benefits because of their gender, they may have turned this into an asset, since a woman writer could arouse readers' curiosity precisely for that same reason. The feminine identity is underlined in every woman writer's paratext when the book is meant to compete in the market. ${ }^{45}$ Although the trope was usually meant to fashion a humble authorial position, in these cases it aimed to add interest to the work and invite the reader to behave courteously, i.e. more favourably, towards the female author.

María de Zayas' Novelas ejemplares were a great success. There were five or six different editions between 1637 and 1646, a compelling reason to write a sequel. The real economic benefit she obtained is difficult to determine. The work does not bear privilegio (privilege), which was the exclusive right to print a book for a certain period, so others could take advantage and reprint it without the author's permission. In her second collection of short stories or novelas, she mentions her success and boasts that the work "has enjoyed three prints, two natural and one stolen" ("ha gozado de tres impresiones, dos naturales y una hurtada"), ${ }^{46}$ suggesting that two of those editions had her permission and economic control and the third was made by an unscrupulous printer, underlining again that the work was very profitable. The success and fame it brought opened the way to publishing and most probably pushed her to write a second collection of ten novels. It is now known as Desengaños amorosos (Deceits of Love), although it was originally published as Segunda parte del sarao y entretenimiento honesto (Second Part of the Soiree and Honest Entertainment, Zaragoza, 1647) establishing a clear association with the Novelas amorosas to take advantage of the previous book's fame, according to market logic. Although it was a success, it is unclear if Zayas benefited from this second book, ${ }^{47}$ but it is

45 For instance: Ana de Leyva, Ana de Castro or Ana Caro, apart from María de Zaya - see BIESES database for information on their works. Esther Villegas explores how some women used gender as a visibility mark for literary purposes: "Transatlantic interactions: seventeenth century women authors and Literary self-consciousness" in Identity, Nation, Discourse. Latin American Women Writers and Artists, ed. Claire Taylor, Newcastle upon Tayne 2009, 104-21.

46 María de Zayas, Desengaños amorosos, ed. Alicia Yllera, Madrid 1983, 258.

47 The edition and the problematic text leads some to believe that "The author neither gave the manuscript to the editor (the dedication to the Duke of Híjar is not hers) nor even had a fully finished text so the book seller tried to arrange it as he could" [my translation], Enrique Suárez Figaredo, "María de Zayas y Sotomayor, Desengaños amorosos" Lemir, 18 (2014), 29; Yllera, who most kindly lent me her copy of the first edition, shares this impression. 
obvious that both works follow the same narrative pattern to produce a commodity. Although critics have pointed out differences between both collections and how the passage of time seems to have produced a strong disenchantment in Zayas, both works not only follow the same narrative formula uniting love tales by the frame story, but they are also set in an academic scenario and with the same characters.

Caro's and Zayas' literary careers prove some women writers managed to put their works in the market in the same way men did, following similar courses of action. This path began participating in local coteries, literary academies, or informal group meetings where connections and recognition could be gained. Poetry was the touchstone, used for the expression of all kinds of topics and necessary for attention and appreciation from the audience. These groups were effective in gaining fame and establishing relationships or simply providing access to persons of high social position and receiving potential patronage, because coteries integrated members of different social classes but were usually sponsored by people of the local elite. ${ }^{48}$ This was the starting point to promote one's literary abilities and eventually seek an economic return for them, either by exploiting opportunities of patronage or by printing for the market. The same handwritten texts that were read and circulated in such coteries could be proposed to patronage or disseminated through the press, as suggested by Pérez de Montalbán mentioning Zayas' novels before publication. ${ }^{49}$ Moreover, literature was often printed after manuscript dissemination and endorsement in these circles. Caro and Zayas were the most successful women writers and prove that gender did not exclude women from the literary market. Their visibility at the time was high enough to make an example for other female writers who realised literary creation could be more than a highbrow and elegant hobby. And, in the same years or sometime after, other woman writers followed suit and published works of the same marketable genres: relaciones, novels and dramas. ${ }^{50}$ In these cases, there is no information on writers' biographies so their professional paths remain unknown, but the genres they chose and the resulting published books suggest they were looking for profit.

48 Jeremy Robbins, Love Poetry of the Literary Academies in the Reign of Philip IV and Charles II, London 1997, 7-46.

49 Juan Pérez de Montalbán, Para todos. Ejemplos morales, humanos y divinos en que se tratan diversas ciencias, materias y facultades repartidos en los siete días de la semana y dirigidos a diferentes personas, Huesca 1633, f. 353v. Pérez de Montalbán says her book is ready for print, but he talks about eight novels and the actual text has ten.

50 See Section III ("Secular literature") and Section Iv ("Women in the Public Sphere") in The Routledge Companion to Early Modern Spanish Women Writers, eds Baranda and Cruz. 


\section{Women Writers in the Literary Market}

In 1638, Ana de Leyva published a eulogy (Panegírico) to Francisco d'Este, Duke of Modena, upon his entrance to Madrid. The Duke was on an official visit to the King of Spain and had a reputation as a generous patron of the arts, something Ana de Leyva stresses in her dedication when she says that a magnificent prince is recognised by his liberality when receiving a small gift. ${ }^{51}$ Angela de Azevedo, possibly of Portuguese origin, might have also written her plays to be staged and to appeal to theatre audiences. The titles of her three works begin with "famous comedy", usually an indication that they had been previously bought by the impresario and performed as such..$^{52}$ It is believed Mariana de Carvajal wrote her collection of novels Navidades de Madrid (Christmastide in Madrid) also to earn money.

Mariana de Carvajal was widowed in 1656 with eight children. In all likelihood, this was her main reason for writing novels, as - although she belonged to a wealthy class, had an allowance and was well connected to people that helped her - it seemed she was in need of money. ${ }^{53}$ Her writing career is unknown; she is not mentioned before or after the publication of her book, although her prose narratives contain many poems that could have been composed for some kind of academy or coterie. Her work has no commendatory poems that might prove her literary connections, but writing appears to be a family pursuit as her son presided over an academy in $1664,{ }^{54}$ and the lack of preliminary texts might be the result of the printing process and not

51 Ana de Leyva, Panigírico en alabanza de la serenissima alteza del gran Francisco de Este duque potentissimo de Modena, Madrid 1638. I shall not refer to Ana de Castro Egas, Eternidad del Rey don Filipe Tercero nuestro señor, el piadoso (Madrid 1629), because according to Peraita her reasons for writing the work may have not been economic only, see Carmen Peraita Huerta, "Apacible brevedad de los renglones, abreviada vida de monarcas: Ana de Castro Egas, Francisco de Quevedo y la escritura del panegírico regio", La Perinola. Revista de Investigación Quevediana, 9 (2005), 151-70; other woman writers who published booklets as a means of developing a literary career in $\mathrm{M}^{\mathrm{a}}$ Carmen Marín Pina, "Pliegos sueltos poéticos femeninos en el camino del verso al libro de poesía. La singularidad de María Nieto", Bulletin Hispanique, 113/1 (2011), 239-67.

52 The works are Comedia famosa. La margarita del Tajo que dio nombre a Santarén, Comedia famosa, Dicha y desdicha del juego y devoción de la Virgen, and Comedia famosa, El muerto disimulado, see Teresa Scott Soufas, Women's Acts. Plays by Women Dramatists of Spain's Golden Age, Lexington 1997, 4-132.

53 See Shifra Armon, Picking Wedlock. Women and the Courtship Novel in Spain, Lanham [etc.] 2002, 43-44 and 173-75

54 On Carvajal's possible participation in academies or coteries, see Moisés Martín Gómez, Mariana de Carvajal: "Industrias y desdenes". Un estudio de las "Navidades de Madrid", Cádiz 2003, 30-34 and 39-40. 
due to the author's isolation. Apart from poetry writing, which was something every young writer did, Mariana de Carvajal seems to have been interested only in commercial genres, novels and plays which were very much in demand as leisure literature. Zayas openly urged readers to buy the book; in her prologue, Carvajal offers the reader "a book with twelve comedies" ("un libro de doce comedias") 55 that she had apparently already composed. She closes the work implying that she is willing to write the second part of the collection. She is not as bold as Zayas in expressing herself, but had the same goal: to try to raise expectations in the reader (prospective buyer), a reason for referring to the most commercial and avidly consumed genres of the time, as editions of plays had increased steadily and collections of novels were published continuously. ${ }^{56}$ The paratexts of Navidades de Madrid suggest that Mariana de Carvajal took all necessary steps to obtain the required printing permissions, even the privilege, which was optional and had primarily an economic purpose. As with Zayas, authors usually obtained it in order to sell the work to a publisher who paid them either with money or book copies, ${ }^{57}$ a negotiation that involved convincing editors of the book's possible success in the market. Once the author sold the original manuscript he or she had no say in the printing process; this is something I argue happened to the Navidades de Madrid, particularly as some mistakes in the text suggest Carvajal never corrected the printed book. ${ }^{58}$ Driven by adverse economic circumstances, Mariana de Carvajal tried her luck in a successful genre in the market and was shrewd enough to get legal permits and sell her work, thus following the same steps as other authors of her time. That could explain why the book publisher, Gregorio Rodríguez, wrote the dedication to Eusebius von Pötting, the Viennese ambassador. He chose a patron, who had arrived in Madrid a few months before and had a reputation as a bookish and generous man. If Carvajal received payment for her literary endeavour, the publisher sold copies and was rewarded by the patron, who says in his

55 "Forgive the shortcomings of a bad cut pen, where you will find more eagerness to serve you with a book with twelve comedies, in which you will know my fondness" ("perdonando los defectos de una tan mal cortada pluma, en la cual hallarás mayores deseos de servirte con un libro de doce comedias, en que conozcas lo afectuoso de mi deseo"), Mariana de Carvajal, Navidades de Madrid y noches entretenidas, ed. Catherine Soriano, Madrid 1993, 5 .

56 Anne Cayuela, Le paratexte au Sicle d'Or. Prose romanesque, livres et lecteurs en Espagne

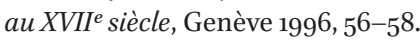

57 Cayuela, Le paratexte, 59-62; and Jaime Moll, "Problemas bibliográficos del libro del Siglo de Oro", Boletín de la Real Academia Española, LIX/216 (1979), 49-107. 
diary: "To him who dedicated a book called Christmastide in Madrid to me, I have given ten doublons". ${ }^{5}$

The emergence of a market for literary products and the resulting partial independence of certain authors was a phenomenon that took over a century to develop since the advent of the printing press. However, writers practiced the rationale of profit long before then, since the beginning of the printing press, as there were large consumption genres that led to business expectations. Chivalry romances were possibly the most popular genre in sixteenthcentury Spain (and Europe) since the Amadis of Gaul success in 1508, soon followed by a number of sequels. ${ }^{60}$ Juana Bernal de Gatos was aware of this when, in 1584, she asked permission for a new edition of Cristalián de España, a chivalry book written by her mother, Beatriz Bernal, and first published in 1545. As Carvajal, Juana declares she is a widow and explains that she wants some income, because she is poor and in need. Nothing is known about the reasons or process leading to the first edition in 1545 as Beatriz Bernal's name is not on it, just "a lady from Valladolid" ("una señora de Valladolid"). Economic imperatives for writing or printing the book are difficult to assess. The printing license was requested and granted in 1537 to a "Mossior of Anthoven" and the privilege belonged to the editor, Christóbal Pelegrin: two men who could have been essential intermediaries for Beatriz Bernal to obtain legal permits. Nevertheless there were too many people involved in Bernal's project for it not to have economic interests, particularly as, in 1532 in Valladolid, three chivalry books were published along with two more in 1545 , meaning it was a popular genre. ${ }^{61}$ Juana Bernal clearly states economic motivation as reason to publish her mother's work, but it is surprising that the archival documents Gagliardi recovered ${ }^{62}$ show she was affluent. Official requests were often based on such topical reasons, so it is not odd Juana spoke of herself as a poor widow if that could ease the procedure. Whether profitable or not, either for money or for other reasons, her petition is evidence of the fact that society accepted, even in the sixteenth century and in a limited literary book market, women's initiatives to obtain benefits from printing a work. They

59 "A uno que me dedicó un libro llamado Navidades de Madrid he dado 10 doblones" Armon, Picking Wedlock, 175 .

6o M. ${ }^{a}$ Carmen Marín Pina, "Los libros de caballerías castellanos", in "Amadís de Gaula", 1508: quinientos años de libros de caballerías, ed. José Manuel Lucía Megías, Madrid 2008, 165-9o.

61 Donatella Gagliardi, Urdiendo ficciones. Beatriz Bernal, autora de caballerías en la España del siglo XVI, Zaragoza 2010, 133-39.

62 Ibid., 79-103. 
were perfectly aware of this possibility, which could stimulate their interest in writing. ${ }^{63}$

\section{Professional Wise Maidens}

Monetary gains hint at a market society in which profit is expressed in clearly quantifiable terms, but there were other ways to benefit from knowledge or writing abilities. Although he made money, Lope de Vega always longed for a permanent job as chronicler or secretary, which he never got. More generally, writers sought means to be rewarded with favours or gifts within the patronage system of the time. Women were aware of these alternative forms of profit, too, and wrote in order to obtain them. For example, Luisa Sigea held well-paid positions in court because of her knowledge of classical languages. In her youth, Bernarda Ferreira de Lacerda dedicated a poem to King Philip III, in which certain Portuguese family lineages are highlighted with a view to promoting them. Also, in convents, many nuns resorted to writing to help solve economic problems, to meet certain domestic needs, or to sustain patronage networks. These women used literature not as simple amusement or a free expression of their creativity, but with a utilitarian purpose resulting from carefully thought-out decisions.

Some women writers, including Ana Caro and Ana de Leyva, sought aristocratic patronage, but their reward was some form of payment for a piece of work. Striving for a position or a job based on their literary talents was out of the question: women could not be secretaries or chroniclers. Ladies of the Queen's chamber had their own institutional space and received a salary for their work, among other forms of compensation. In a sense, it was one of the few professional opportunities for aristocratic and elite women. ${ }^{64}$ Because of the restricted and exclusive character of this group, it was especially difficult to get access unless you were a member of the aristocracy; however, some women attained it because of their knowledge.

63 Being a poor widow cannot be discarded as the major reason for getting permission, as widows were a particularly disadvantaged group that the law and society as a whole were inclined to protect. It seems that women were particularly attracted by the chivalric genre and although Beatriz Bernal is the only known author, other works are said to have been composed by women in a covert way, for example the Palmerín de Olivia. In Italy and

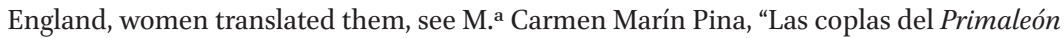
y otros versos laudatorios en los libros de caballerías", in Actes del X Congrés Internacional de l'Associació Hispànica de Literatura Medieval (Alacant, 16-20 setembre de 2003), Alacant 2005, 2, 1057-66, and Gagliardi, Urdiendo ficciones, 105-36.

64 M. Victoria López-Cordón, "Entre damas anda el juego: las camareras mayores de Palacio en la edad moderna”, Cuadernos de Historia Moderna, 123 (2003), 126. 
Luisa Sigea (c. 1522-1560) and her sister, Angela, were daughters of a humanist professor who taught Spanish and Portuguese to aristocratic families, and this was possibly the reason why he decided to educate his daughters following the model of the 'new aristocrat' ladies who learnt classical languages and culture. ${ }^{65}$ The girls mastered Greek, Latin, grammar, rhetoric and music, and, using their connections, they entered the Portuguese court to serve Queen Catherine and Infanta Maria of Portugal. According to the Livros de moradia or Queen Catherine ledgers, in 1543, 1550, and 1551, Luisa received as latina (Latin teacher or secretary) 16 ,ooo reis annually. The amount measures her importance in comparison to other educated ladies, for example, Joana Vaz, who taught Latin and received 10,000 reis in 1550. While living in the Portuguese court, Sigea composed a Latin poem and a dialogue dedicated to the Infanta, but was not paid for them. Her profit came instead from her increased influence inside and outside of court and her promotion as a cultivated intellectual, which bolstered her professional value. European fifteenth- and sixteenth-century professional humanists began their careers teaching and their prospects increased as their prestige grew, allowing them sometimes to become court scholars. Luisa Sigea could not become a college professor, but because of her upbringing and her father's connections to the Portuguese court (albeit not from a great lineage), she was allowed to enter Queen Catherine's chamber around 1540. She proceeded, like other humanists, to self-fashion a 'wise woman' image through letters to important people, including the Pope. Although, in 1540, she sent him some poems in Latin, Sigea is remembered in lists of European famous women for having sent a letter to Pope Paul III in five languages: Latin, Greek, Arabic, Hebrew, and Chaldean. The now lost text is always mentioned as a letter, but writing a letter in five languages can only be considered an exercise in scholarly exhibition to demonstrate a huge breadth of knowledge. Such a text was presumably made for promotional reasons as, from Rome's adequate circles and the summit of Catholic power, news could tour Europe and return to the Portuguese court in the form of admiration. In fact John Vaseo (1552), Francisco de Pisa (1605), Andreas Schott (1608) and Pietro Paolo Ribera (1609) among others, mentioned this extraordinary woman in their works and her letter to the Pope is the most commented upon feat. ${ }^{66}$ Unlike most of the Infanta's chamber ladies, Luisa Sigea did not descend from a great lineage and strengthened her court position by writing in the language of the cultural elite. Writing in

65 Nieves Baranda, "Luisa Sigea, la brillante excepción femenina", in Melchor Cano y Luisa Sigea. Dos figuras del Renacimiento español, ed. Miguel Ángel Pérez Priego, Tarancón 2008, 129-51.

66 Information on these and other citations can be retrieved in BIESES data base by searching "Sigea menciones coetaneas". 
Latin, she flattered Infanta Maria in dedications (Sintra and Coloquium), and her letters remind everyone from time to time that she is a remarkable woman. In the various scales of prestige operating in court, Sigea places herself at the summit where the fields of woman and classical learning meet, but as symbolic positions are very unstable their bases must be constantly renewed. Latin letters addressed to powerful and famous men of the time served to preserve and consolidate her personal and professional position. ${ }^{67}$

Luisa Sigea married a Spanish court steward and went to live in Castile. Between 1556 and 1558, the couple was in the service of Emperor Charles V's sisters, but when the Empress Dona Maria died they had to find new positions. Sigea died in 156o, but in those two years, she could not return to work in the court, as she had wanted, although she addressed many influential people and kept in touch with courtly literary circles. ${ }^{68}$ Her frustration is a symptom of a new reality: from this point onwards, Spanish 'wise women', those who were highly educated, could not develop their intellectual skills except from the inside of convents. Juliana Morell's (1594-1653) excellent education in Latin was employed in commenting on religious works while living in the convent of Sainte Praxède of Avignon (France). The well-known writer sor Juana Inés de la Cruz (1651-1695), after a short period in the vice-royal court in Mexico when she was 13 and 14, wrote from a Hieronymite monastery in the city. ${ }^{69}$

\section{The Quiet Writing Jobs of Nuns}

Nun writers are most commonly associated with autobiographical writing and accounts of religious experiences, such as Teresa of Avila. However, leaving aside liturgical and meditative texts used in monasteries, the prevailing literary genre was poetry. ${ }^{70}$ Usually sung, it was used in many ways: in everyday and special

67 Only four Spanish and 19 Latin letters remain, see Léon Bourdon and Odette Sauvage, "Recherches sur Luisa Sigea", Bulletin des Études Portugaises, XXXI (1970), 33-176; and M.R. Prieto Corbalán, Luisa Sigea, epistolario latino, Madrid 2007.

68 Nieves Baranda, "Feminae poeticae. Una generación de mujeres poetas de mediados del siglo XV", in Grandes y pequeños de la literatura medieval y renacentista, ed. Emilio Blanco, Salamanca 2016, 17-53.

69 See Theresa M. Lamy, Juliana Morell: Child Prodigy, Religious Reformer, Spiritual Writer, New York University, Graduate School of Arts and Science, 1992 (PhD. Thesis), and one of the latest sor Juana's biographies, although there are more, Alejandro Soriano Vallès, Sor Juana Inés de la Cruz, Doncella del Verbo, México 2010.

70 Nieves Baranda, "Producción y consumo poéticos en los conventos femeninos", Bulletin Hispanique, CXv/1 (2013), 165-84. 


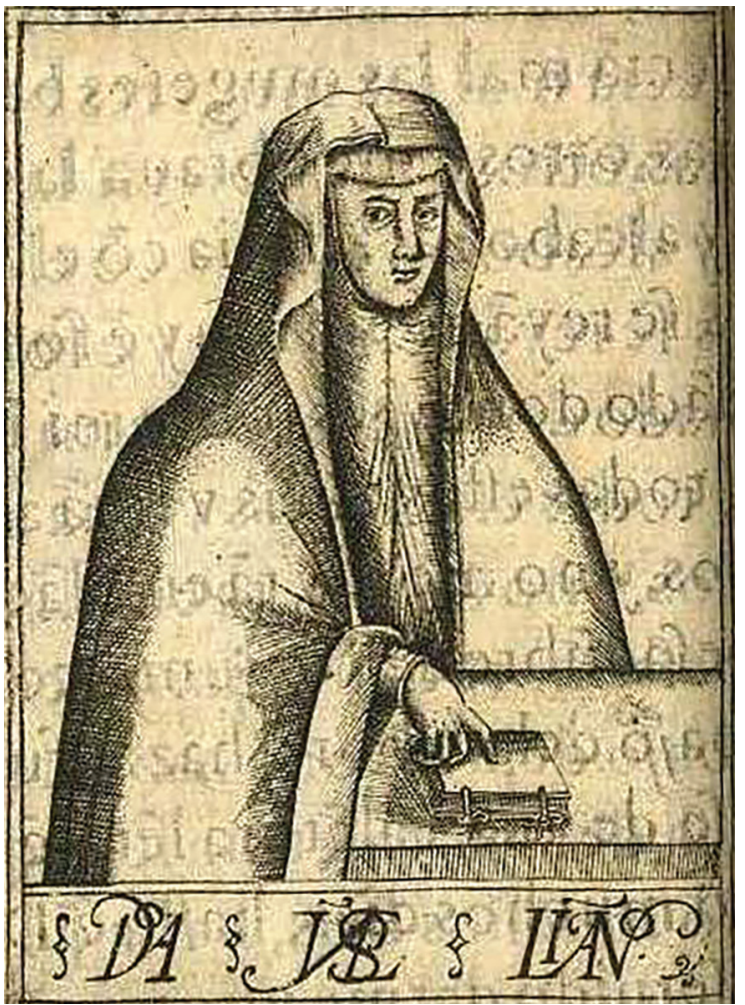

FIGURE 3.1 Isabel de Liaño, Vida de santa Catalina de Siena, Valladolid, 16o4, engraving in page $9 v$. ordered by the woman writer and representing her dressed as a widow making a typical authorial sign touching the book with her finger. COURTESY OF THE HISPANIC SOCIETY OF AMERICA, NEW YORK.

occasions or ceremonies that had to be solemnised with music, mostly associated with religious lyrics in Spanish. Used to sing popular traditional songs a lo divino (changing the original profane words to give them a religious content), many nuns easily composed small poems for their private use as prayers or to be shared with the community. However, formal occasions needed quality verses to be sung to music and had to be composed by experts. ${ }^{71}$ It can be concluded that seventeenth-century monasteries contributed to a poetry trade to meet their needs, although there is scarce documentary evidence of this.

71 Music's importance in convents and its economic side will not be commented on in this chapter, although it was closely related to poetry, see Colleen Baade, "'Hired Nun Musicians in Early Modern Castile" in Musical Voices of Early Modern Women: Many-Headed Melodies, ed. Thomasin LaMay, Aldershot/Burlington 2005, 287-310. 
Sor Marcela de San Félix (1605-1687), a Trinitarian nun and talented poet, presents in one of her short plays a poor starving student wondering how to compose a loa (short dramatic preliminary piece), because some nuns had promised to give him food for the work. ${ }^{72}$ The play proves convents turned to local poets, either well known or simply amateurs, when poems for special occasions were needed. Professional and famous writers, such as Vicente Sánchez or León Marchante, include in their works poems composed for celebrations in feminine monasteries, and there are a few plays written by male authors for festivities in convents. ${ }^{73}$ Sor Marcela's play provides evidence that some proficient nuns were able to meet convent literary needs. She did not write her works to be sold, but her compositions contributed to the community's economy because it did not buy texts. The register of deceased sisters (necrologio) of the Anunciada monastery in Villafranca del Bierzo (León) says of Mother Bernardina de Jesús: "While a novice our mother vicaress taught her to paint registers and other nice things. When vicaress herself, she painted and decorated the cloisters, made drawings for and prepared church ornament embroideries, and thereby the Community saved many ducats". ${ }^{74}$ The key concept is saving. Indeed, nun writers were profitable for their communities and contributed to their revenues not by selling their texts, but by avoiding expenses. This might be the reason why priests who disapproved of women's writing did not complain of those who were even forced to do it on behalf of their own community. For instance the Seville nun, Valentina Pinelo (?- 1629) complains:

All the year I was busy with the order festivities, making some poems that will soon be published ... But that was such a tiring exercise that I have run out of strength and if I had not abandoned that other book I would have

72 Marcela de San Félix, Obra completa. Coloquios espirituales, loas y otros poemas, eds Electa Arenal and Georgina Sabat de Rivers, Barcelona 1988, 361-68

73 On Vicente Sánchez, Lira poética, 1688, and León Marchante (d. 1688), see Baranda, "Producción y consumo", 270-71. The playwright has been studied by Carmen Alarcón Román, "El cumpleaños de la abadesa: una loa de Alonso Martín Brahones en el Convento de Santa Inés de Sevilla (1671)", Teatro. Revista de estudios teatrales, 19 (2003), 107-34, other examples in Antonio Cruz Casado, "Villancicos barrocos andaluces para diversas fiestas del convento de Santa Clara de Montilla (1684-1737)", in El franciscanismo en Andalucía: conferencias del I Curso de verano sobre el franciscanismo en Andalucía (Priego de Córdoba, 7 a 12 de agosto de 1995), ed. Manuel Peláez del Rosal, Córdoba 1997, 325-46.

74 "En el noviciado la enseñó nuestra madre vicaria a pintar registros y otras curiosidades. Siendo vicaria, pintó y decoró los claustros, dibujaba y preparaba el bordado de ornamentos para la iglesia, y con ello ahorró a la Comunidad muchos ducados" [emphasis added, $\mathrm{NB}], \mathrm{M}^{\mathrm{a}}$ del Carmen Arias, La ilustre fundadora de "La Anunciada": María de la Trinidad Toledo y Mendoza (1581-1637), una historia fascinante, Villafranca del Bierzo 2009, 172. 
never finished this one, and here I recovered the health I lost there: the poem book has been the toil and here the recreation..$^{75}$

Nearly a hundred years later in introducing one of her poems, Francisca de Santa Teresa (1654-1709) describes painful circumstances too:

Having funded lady Fabiana Soriana a chaplaincy for her son sir Juan Antonio de los Reyes, sor María de Santa Gertrudis' brother, it was founded in the holy Christ of piety altar, and the day he took up the position ... I was ordered to write in spite of my right hand being hurt. ${ }^{76}$

In her study of convent poetry in Italy, Graziosi wonders why nuns composed poems and, among other reasons, she notes that sometimes they did it because of fame, the small local fame that could draw alms to the convent. ${ }^{77}$ Monasteries were heavily dependent on charity, which came mainly from the surrounding people in the city, so their economic situation deteriorated during the seventeenth century, following the country's living conditions. When there were several monasteries in the same city, competition for these resources was hard, and being remembered and taken into account could be important. Sister Manuela de la Santísima Trinidad's (1622-1696) convent chronicle devoted a chapter to the poverty they lived in, because alms had fallen sharply, so Mercedes Marcos assumes that the reason to publish it could be reminding Salamanca's people that Franciscan nuns were very holy, privileged intercessors before God and worthy of their alms. ${ }^{78}$

75 "me ocupaba todo el año en las fiestas de la orden, haciendo algunas letras que saldrán ahora ... Pero aquel era un ejercicio tan cansado que me han faltado las fuerzas y si no dexara esotro libro nunca acabara este y aquí cobré la salud que allí perdí: en el cancionero ha sido el trabajo y aquí el descanso", Libro de las a labanças y excelencias de la gloriosa Santa Anna, Sevilla 16o1, prologue.

76 "Haviendo fundado doña Fabiana Soriana una Capellanía en su hijo D. Juan Antonio de los Reyes, hermano de Sor María de Santa Gertrudis, fundósse en el Altar del Santíssimo Christo de la Piedad, y el día que tomó la possessión ... me mandaron escribir, teniendo mala la mano derecha", Francisca de Santa Teresa, Poesías de la Madre sor Francisca de Santa Teresa, religiosa trinitaria descalza en la Villa de Madrid, manuscript, 18th century, ff. 217v-219r, apud Isabel Barbeito, Escritoras madrileñas del siglo XVII (Estudio bibliográficocrítico), Universidad Complutense, PhD. Thesis, 1986, 270 [in Bieses website].

77 Elisabetta Graziosi, "Arcipelago somerso. Le rime delle monache tra obbedienza e trasgressione" in I monasteri femminili come centri di cultura fra Rinascimento e Barocco, eds Gianna Pomata and Gabriella Zarri, Roma 2005, 162.

78 Fundación del Convento de la Puríssima Concepción de Franciscas Descalzas de la ciudad de Salamanca, Salamanca 1696, see María Fernanda Prada Camín and Mercedes Marcos Sánchez, Historia, vida y palabra del Monasterio de la Purísima Concepción (Franciscas 
Besides alms, monasteries depended on and cared for their patrons' generosity. Monastery founders and their descendants had a special relationship with the community to which they contributed financially in exchange for continual prayers or other privileges (burial sites, priority for family novices and so on). As with relaciones to flatter patrons, nuns could write for utilitarian aims. Sister Francisca de Santa Teresa's poetry is useful to demonstrate how writing could be productive when some poems are devoted to wish 'happy birthday' to relevant people for the convent:

These two poems to the most glorious martyrs saint Justo and saint Pastor and others that may be found in this book I made at different times commissioned by Mr. Doctor Don Gabriel Sanz, his own priest and His Eminence's convents visitor. Romance for his day.

“To Miss María Rosa de la Cerda Téllez Xirón's two-year birthday, Don Ioseph Manrrique de la Cerda's and Dona Manuela Téllez Xirón's daughter, Marquises of La Laguna, the female author congratulates her with these verses".79

These poems were written to awaken patrons' generosity, even if the nun's work did not seek personal gain, but the community's benefit. It is surprising how nuns' writings refer very often to suffering real poverty and how many documents are related to the economic management of convent property compared to the lack of specific references to the commodification of their artistic skills. Baade, who has studied music extensively, stresses that it is difficult 'to know the extent to which nuns' music-making was motivated by zeal for appropriate worship versus the expectation of possible benefits (prestige? continued financial support from patrons?) that may have been associated with public performances". ${ }^{80}$ And indeed leaves the question unanswered for

Descalzas) de Salamanca, Salamanca, 2001, 161. I thank Mercedes Marcos who called my attention on it. On poverty in Spanish convents see Ángela Atienza, "Lo reglado y lo desarreglado en la vida cotidiana de los conventos femeninos en la España Moderna", in $L a$ vida cotidiana en el mundo hispánico (siglos XVI-XVIII), ed. M. Peña, Madrid 2012, 445-65.

"Estas dos letras a los gloriossíssimos mártires San Justo y Pastor y las que se hallaren en este Libro las hiçe en diferentes ocasiones de mandato del señor Doctor Don Gabriel Sanz, su cura propio y visitador de los conbentos sujetos a su Eminencia. Romance para su día", "Al cumplimiento de los dos años de la Sra. $\mathrm{D}^{\mathrm{a}}$ María Rosa de la Çerda Téllez Xirón, hija de los Excellentíssimos señores Don Ioseph Manrrique de la Cerda y de $\mathrm{D}^{\mathrm{a}}$ Manuela Téllez Xirón, Marqueses de la Laguna, se los da la autora en estas coplas". The Marquisses were the monastery patrons, see Baranda, "Producción y consumo", 173.

8o Coleen Baade, "Music and Misgiving: Attitudes Towards Nuns' Music in Early Modern Spain", in Cordula van Wyhe, Female Monasticism in Early Modern Europe. An Interdisciplinary View, Aldershot 2008, 89. 
lack of data in the sources, as it happens with literature. It is very likely that following elite or court social patterns, literary works, like music, were considered a prestigious sign, an ornamental activity that would degrade when exchanged or produced for money because that would turn it into a commodity. Nuns who had a dowry waive for their artistic or musical abilities, although formally part of the convent elite group, were actually regarded as having an inferior status, as their work had to pay for their living and was subject to commodification. ${ }^{81}$ While in literary circles these concepts changed under the pressure of the publishing market, nuns did not change, so even if the logic of profit was understood and accepted, voicing it was inappropriate.

Literary history tends to present women's writing as an individual act, the result of a creative impulse, a need for expression that manages to overcome social barriers or as a prestigious form of entertainment for the elite. Considering economic aspects in early modern Spain reveals that, despite women's comparative weakness in the literary field, women writers paid to profit no less attention than men. Their works had often an economic or utilitarian purpose and adopted the same tactics employed by men to get the benefit they wanted. Some of them succeeded in doing so.

\section{Bibliography}

\section{Primary References}

Caro, Ana. 1993. El conde Partinuplés (ed. Lola Luna). Kassel: Reichenberger.

Caro, Ana. 1993. Valor, agravio y mujer (ed. Lola Luna). Madrid: Castalia.

Carvajal, Mariana de. 1993. Navidades de Madrid y noches entretenidas (ed. Catherine Soriano). Madrid: Comunidad de Madrid.

Castillo Solórzano, Alonso de. 1972. La garduña de Sevilla y anzuelo de las bolsas (ed. Federico Ruiz Morcuende). Madrid: Espasa-Calpe.

Castro Egas, Ana de. 1629. Eternidad del Rey don Filipe Tercero nuestro señor, el piadoso (Madrid: Viuda de Alonso Martín).

81 "Their productive service activity lowered their prestige in community, however, by likening them to the lay sisters who performed manual chores in the convent. The former servant, Maria de la Santisima Trinidad, could not rise in the status structure because her productive artistic acts continually reminded of her service capacity and Estefania de la Encarnacion's prestige also was diminished by her productive artistic acts in lieu of a dowry", Mindy Nancarrow Taggard, "Art and Alienation in Early Modern Spanish Convents", South Atlantic Review, 65 (2000), 27. Donald Gilbert-Santamaría, Writers on the Market, 24, underlines how the ruling elite in Spain resisted to mercantilist activity out of cultural barriers to the promotion of market ideology beyond the traditional artisan classes. 
Leyva, Ana de. 1638. Panigírico en alabanza de la serenissima alteza del gran Francisco de Este duque potentissimo de Modena. Madrid: Imprenta del Reino.

Marcela de San Félix. 1988. Obra completa. Coloquios espirituales, loas y otros poemas (eds Electa Arenal and Georgina Sabat de Rivers). Barcelona: PPU.

Pérez de Montalbán, Juan. 1633. Para todos. Ejemplos morales, humanos y divinos en que se tratan diversas ciencias, materias y facultades repartidos en los siete días de la semanay dirigidos a diferentes personas. Huesca: Pedro Blusón, a costa de Pedro Escuer.

Pinelo, Valentina. 1601. Libro de las alabanças y excelencias de la gloriosa Santa Anna. Sevilla: Clemente Hidalgo.

Vega Carpio, Félix Lope. 1914. Arte nuevo de hacer comedias [16o9] (tr. William T. Brewster). New York: Dramatic Museum of Columbia University.

Vega Carpio, Félix Lope de. 2002. Laurel de Apolo (ed. Christian Giaffreda). Firenze: Alinea Editrice s.r.l.

Vélez de Guevara, Luis. 1988. El diablo cojuelo [1641] (eds Ángel R. Fernández and Ignacio Arellano). Madrid: Castalia.

Zayas, María de. 199o. The Enchantments of Love: Amorous and Exemplary Novels (tr. H. Patsy Boyer). Berkeley: University of California Press.

\section{Secondary References}

Alarcón Román, Carmen. 2003. 'El cumpleaños de la abadesa: una loa de Alonso Martín Brahones en el Convento de Santa Inés de Sevilla (1671)' in Teatro. Revista de estudios teatrales 19: 107-34.

Arias, $\mathrm{M}^{\mathrm{a}}$ del Carmen. 2009. La ilustre fundadora de "La Anunciada": María de la Trinidad Toledo y Mendoza (1581-1631), una historia fascinante. Villafranca del Bierzo: Instituto de Estudios Bercianos.

Armon, Shifra. 2002. Picking Wedlock. Women and the Courtship Novel in Spain. Lanham [etc.]: Rowman \& Littlefield Publishers.

Atienza, Ángela. 2012. 'Lo reglado y lo desarreglado en la vida cotidiana de los conventos femeninos en la España Moderna' in M. Peña (ed.), La vida cotidiana en el mundo hispánico (siglos XVI-XVIII). Madrid: Abada editores: $445^{-65}$.

Baade, Coleen. 2008. 'Music and Misgiving: Attitudes Towards Nuns' Music in Early Modern Spain' in Cordula van Wyhe (ed.), Female Monasticism in Early Modern Europe. An Interdisciplinary View. Aldershot: Ashgate: 81-96.

Baade, Colleen. 2005. 'Hired Nun Musicians in Early Modern Castile' in Thomasin LaMay (ed.), Musical Voices of Early Modern Women: Many-Headed Melodies. Aldershot and Burlington: Ashgate: $287-310$.

Baranda, Nieves. 2008. 'Luisa Sigea, la brillante excepción femenina' in Miguel Ángel Pérez Priego (ed.), Melchor Cano y Luisa Sigea. Dos figuras del Renacimiento español. Tarancón: Ayuntamiento de Tarancón and Centro Asociado de la UNED de Cuenca: $129-51$. 
Baranda, Nieves. 2011. 'Women's Reading Habits: Book Dedications to Female Patrons in Early Modern Spain' in Anne J. Cruz and Rosilie Hernández (eds), Women's Literacy in Early Modern Spain and the New World. Hampshire and Burlington: Ashgate: $19-39$.

Baranda, Nieves. 2013. 'Producción y consumo poéticos en los conventos femeninos' in Bulletin Hispanique, $\operatorname{cxv}(1): 165^{-84}$.

Baranda, Nieves and Anne J. Cruz (eds). 2017. The Routledge Companion to Early Modern Spanish Women Writers, London/New York: Routledge. [Spanish trans. Escritoras españolas de la edad Moderna. Historia y guía de investigación. Madrid: UNED, 2018.]

Barbeito, Isabel. 1986. Escritoras madrileñas del siglo XVII (Estudio bibliográfico-crítico). PhD. Thesis. Universidad Complutense. [in Bieses website].

Bourdieu, Pierre. 1995. Las reglas del arte. Génesis y estructura del campo literario. Barcelona: Anagrama.

Bourdon, Léon and Odette Sauvage. 1970. 'Recherches sur Luisa Sigea' in Bulletin des Études Portugaises XXXI: 33-176.

Cañadas, Iván. 2005. Public theater in Golden Age Madrid and Tudor-Stuart London: Class, Gender and Festive Community. Aldershot/Burlington: Ashgate.

Cañas Murillo, Jesús. 200o. 'Lope de Vega, Alba de Tormes y la formación de la comedia' in Anuario de Lope de Vega vi: 75-92.

Carrión Arregui, Ignacio M. 20oo. 'El trabajo en una manufactura real del siglo XVII: los armeros de la Armería de Tolosa' in Vasconia 30: 73-82.

Cayuela, Anne. 1996. Le paratexte au Sicle d'Or. Prose romanesque, livres et lecteurs en Espagne au XVII e siècle. Genève: Droz.

Colomer, José Luis. 2005. 'El conde de la Roca y el marqués Virgilio Malvezzi. Dos diplomáticos panegiristas del Conde Duque de Olivares' in Christophe Couderec and Benoit Pellistrandi (eds), Por discreto y por amigo. Mélanges offerts à Jean Canavaggio. Madrid: Casa de Velázquez: 513-34.

Cruz Casado, Antonio. 1997. 'Villancicos barrocos andaluces para diversas fiestas del convento de Santa Clara de Montilla (1684-1737)' in Manuel Peláez del Rosal (ed.), El franciscanismo en Andalucía: conferencias del I Curso de verano sobre el franciscanismo en Andalucía (Priego de Córdoba, 7 a 12 de agosto de 1995). Córdoba: Caja de Ahorros y Monte de Piedad de Córdoba: 325-46.

Elliot, John H. 1986. The Count-Duke of Olivares. The Statesman in an Age of Decline. New Haven: Yale University Press.

Enciso Alonso-Muñumer, Isabel. 2008. 'Nobleza y mecenazgo en la época de Cervantes', in Anales Cervantinos, 40: 47-61.

Ferrer Valls, Teresa. 2003. 'La fiesta en el Siglo de Oro: en los márgenes de la ilusión teatral' in Teatro y fiesta del Siglo de Oro en tierras europeas de los Austrias. Madrid: SEACEX: $27-37$. 
Ferrer, Teresa. 2009. 'La mujer sobre el tablado en el siglo XVII: de actriz a autora' in Damas en el tablado. Actas de las XXXI Jornadas Internacionales de teatro clásico de Almagro (1-3 de julio de 20o8). Almagro: Universidad de Castilla-La Mancha: 83-10o. Gagliardi, Donatella. 2010. Urdiendo ficciones. Beatriz Bernal, autora de caballerías en la España del siglo XVI. Zaragoza: Prensas Universitarias de Zaragoza.

Gamboa, Yolanda. 2011. 'María de Zayas, or Memory Chains and the Education of a Learned Woman', in Anne J. Cruz and Rosilie Hernández (eds), Women's Literacy in Early Modern Spain and the New World. Hampshire and Burlington: Ashgate: 209-24.

García Santo-Tomás, Enrique. 20oo. 'Lope, ventrílocuo de Lope: Capital social, capital cultural y estrategia literaria en las Rimas de Tome de Burguillos (1634)' in Bulletin of Spanish Studies, 77(4): 287-303.

Gilbert-Santamaría, Donald. 2005. Writers on the Market. Consuming Literature in Early Seventeenth-Century Spain. Lewisburg: Bucknell University Press.

Gómez García, Pedro. 1999. 'Hipótesis sobre la estructura y función de las fiestas' in La fiesta, la ceremonia, el rito. Granada: Universidad de Granada: 51-62.

Graziosi, Elisabetta. 2005. "Arcipelago sommerso. Le rime delle monache tra obbedienza e trasgressione" in Gianna Pomata and Gabriella Zarri (eds), I monasteri femminili come centri di cultura fra Rinascimento e Barocco. Roma: Edizioni di Storia e Letteratura: $145^{-73}$.

Gudiol, José. 1973. Velázquez, 1599-166o: historia de su vida, catálogo de su obra, estudio de la evolución de su técnica. Barcelona: Polígrafa.

Gutiérrez, Carlos M. 2005. La espada, el rayo y la pluma. Quevedo y los campos literario y de poder. West Lafayette, Ind.: Purdue University Press.

Huerta Calvo, Javier (ed.). 2003. Historia del teatro español. Madrid: Gredos.

Kaplisch-Zuber, Christine. 1985. 'Rituals publics et pouvoir d'état' in Culture et ideologie dans la genese de l'état moderne. Rome: École française de Rome: 136-53.

Lamy, Theresa M. 1992. Juliana Morell: Child Prodigy, Religious Reformer, Spiritual Writer. PhD. Thesis. New York University.

López Estrada, Francisco. 1978. 'La relación de las fiestas por los mártires del Japón, de doña Ana Caro de Mallén (Sevilla), 1628' in Libro-homenaje a Antonio Pérez Gómez. Cieza: La fonte que mana e corre: II 5 1-69.

López Estrada, Francisco. 1983. 'Costumbres sevillanas: el poema sobre la Fiesta y Octava celebradas con motivo de los sucesos de Flandes en la Iglesia de San Miguel (1635), por Ana Caro de Mallén' in Archivo Hispalense LXVI(203): 109-50.

López Estrada, Francisco. 1983. 'La frontera allende el mar: el romance por la victoria de Tetuán (1633) de Ana Caro de Mallén’ in Dámaso Alonso (ed.), Homenaje a José Manuel Blecua, ofrecido por sus discípulos, colegas y amigos. Madrid: Gredos: 337-46. López-Cordón, M. Victoria. 2003. 'Entre damas anda el juego: las camareras mayores de Palacio en la edad moderna' in Cuadernos de Historia Moderna, 123: 123-152. 
Luna, Lola. 1992. Ana Caro, una escritora profesional del Siglo de Oro. Viday obra. Ph.D. Thesis. Universidad de Sevilla.

Maravall, José Antonio. 1981. La cultura del barroco. Análisis de una estructura histórica. Barcelona: Ariel.

Marín Pina, M. ${ }^{a}$ Carmen. 2005. 'Las coplas del Primaleón y otros versos laudatorios en los libros de caballerías' in Actes del X Congrés Internacional de l'Associació Hispànica de Literatura Medieval (Alacant, 16-20 setembre de 2003). Alacant: Institut Interuniversitari de Filologia Valenciana: 2, 1057-66.

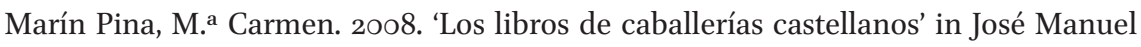
Lucía Megías (ed.), “Amadís de Gaula”, 1508: quinientos años de libros de caballerías. Madrid: Biblioteca Nacional de España/Sociedad Española de Conmemoraciones Culturales: $165^{-9}$ o.

Marín Pina, Ma Carmen. 2011. 'Pliegos sueltos poéticos femeninos en el camino del verso al libro de poesía. La singularidad de María Nieto' in Bulletin Hispanique $113(1): 239-67$.

Marín Pina, Ma Carmen. 2017. 'Public Poetry' in Baranda and Cruz (2017): 205-18.

Maroto Camino, Mercedes. 1999. 'Maria de Zayas and Ana Caro: The Space of Woman's Solidarity in the Spanish Golden Age' in Hispanic Review 67: 1-16.

Martín Gómez, Moisés. 2003. Mariana de Carvajal: "Industrias y desdenes". Un estudio de las "Navidades de Madrid". Cádiz: Universidad de Cádiz.

Martos Pérez, María Dolores. 2017. 'De musas a poetas: escritoras y enunciación canonizadora en la obra de Lope de Vega', Arte nuevo 4: 787-847.

Moll, Jaime. 1974. 'Tercera parte de las comedias de Lope de Vega Carpio y otros autores, falsificación sevillana' in Revista de Archivos, Bibliotecas y Museos 77: 619-26.

Moll, Jaime. 1979. 'Problemas bibliográficos del libro del Siglo de Oro' in Boletín de la Real Academia Española LIX(216): 49-107.

Nancarrow Taggard, Mindy. 2000. 'Art and Alienation in Early Modern Spanish Convents' in South Atlantic Review 65: 27.

Noble Wood, O.J. Roe, J. Lawrence (eds). 2011. Poder y saber. Bibliotecas y bibliofilia en la época del conde-duque de Olivares, Madrid: Centro de Estudios Europa Hispánica.

Osuna, Inmaculada. 2017. 'Literary Academies and Poetic Tournaments' in Baranda and Cruz (2017): 153-67.

Peraita Huerta, Carmen. 2005. 'Apacible brevedad de los renglones, abreviada vida de monarcas: Ana de Castro Egas, Francisco de Quevedo y la escritura del panegírico regio' in La Perinola. Revista de Investigación Quevediana 9: 151-70.

Pérez Pastor, Cristóbal. 1910. Noticias y documentos relativos a la historia y literatura españolas, Madrid: RAE.

Prada Camín, María Fernanda and Marcos Sánchez, Mercedes. 20o1. Historia, vida y palabra del Monasterio de la Purísima Concepción (Franciscas Descalzas) de Salamanca. Salamanca: Publicaciones Universidad Pontificia. 
Prieto Corbalán, M.R. 2007. Luisa Sigea, epistolario latino. Madrid: Akal.

Profetti, Ma Grazia. 1999. 'Poder y estrategias editoriales de Lope de Vega', in M.G. Profeti y A. Redondo (eds), Représentation, écriture et povoir en Espagne a l'epoque de Philippe III (1598-1621). Firenze: Alinea: 87-105.

Robbins, Jeremy. 1997. Love Poetry of the Literary Academies in the Reign of Philip IV and Charles II. London: Tamesis.

Sánchez Arjona, José. 1898. Noticias referentes a los anales del teatro en Sevilla, desde Lope de Rueda hasta fines del siglo XVII. Sevilla: Imp. de E. Rasco.

Scott Soufas, Teresa. 1997. Women's Acts. Plays by Women Dramatists of Spain's Golden Age. Lexington: The University Press of Kentucky.

Soriano Vallès, Alejandro. 2010. Sor Juana Inés de la Cruz, Doncella del Verbo. México: Garabatos.

Suárez Figaredo, Enrique. 2014. 'María de Zayas y Sotomayor, Desengaños amorosos' in Lemir, 18: 353-572.

Villegas, Esther. 2009. 'Transatlantic interactions: seventeenth century women authors and Literary self -consciousness' in Claire Taylor (ed.), Identity, Nation, Discourse. Latin American Women Writers and Writers. Newcastle upon Tayne: Cambridge Scholars: 104-21.

Walker, Kim. 1996. Women Writers of the English Renaissance. New York: Twayne Publishers.

Wright, Elizabeth R. 2001. Pilgrimage to Patronage. Lope de Vega and the Court of Philip III, 1598-1621. Lewisburg: Bucknell University Press.

Zuese, Alicia R. 2011. 'Ana Caro and the Literary Academies of Seventeenth-Century Spain' in Anne J. Cruz and Rosilie Hernández (eds), Women's Literacy in Early Modern Spain and the New World. Hampshire and Burlington: Ashgate: 191-208. 


\title{
Fighting for Her Profession: Dorothe Engelbretsdatter's Discourse of Self-Defence
}

\author{
Marie Nedregotten Sørbø
}

\begin{abstract}
As Aphra Behn argued for her vocation as the first professional woman writer in England, a six-year older Norwegian colleague did the same from her corner of Europe. Dorothe Engelbretsdatter (1634-1716) is considered the first professional poet in DenmarkNorway. Her fight for her art and her livelihood was sometimes fierce. The need to earn money from her writing made her try to defend her copyrights. There were pirate editions attempting to cash in on her success, and she turned on the publishers with entertaining if harsh polemics. Others accused her of plagiarising male predecessors, and she responded in counter-attacks in the form of occasional verse. Her fights paid off, and she was awarded royal support in the form of tax release for life. Her publication history and struggles throw light on the possibilities and limitations of women's entrance into the market of commercial publication around 1700 . Her explicit polemics as well as the argument implied in much of her poetry, that women could and should write, reminds us of similar features in the texts of Behn or Anne Bradstreet. Her seemingly humble submission to male superiority while aiming kicks at the trouser folk, demonstrates the urgently felt need to be admitted to the book market.
\end{abstract}

When a canon of 25 works from across the ages was set up for the Norwegian Literary Festival in 2007, only four women were represented among 21 men. ${ }^{1}$

1 The four chosen women were (in chronological order) Camilla Collett, Sigrid Undset, Cora Sandel and Gunvor Hofmo. The publication of a collection of essays on the selected works, Norsk littercer kanon, confirmed the attempted canonization (Norsk littercer kanon, eds Stig 
The two selected (male) writers from around 1700, Petter Dass and Ludvig Holberg, had one thing in common not mentioned in that document: they both admired Dorothe Engelbretsdatter. ${ }^{2}$ She, however, does not appear at all in the selection, in spite of being considered Norway's first professional poet of any gender, and certainly one of the most popular in her own time. ${ }^{3}$ Modern reception has been much cooler, and a multi-volume cultural history from 1930 reflects both tendencies:

The most famous Norwegian hymn-writer of the Seventeenth Century was Dorothe Engelbretsdatter, a clergyman's daughter and clergyman's wife from Bergen. In her own time, she was highly admired even by real [sic] poets like Kingo, but the admiration was probably more for the clergyman's wife than for her work. In our time, one needs to be a literary historian to be able to admire her: her language, thinking and expressions are all too distant from us.

It is quite a different feast to read Petter Dass, the only Norwegian poet of the Seventeenth Century. ${ }^{4}$

This dismissive distinction between hymn-writers and "real" poets, the preference for her male colleagues, and the suspicion that her admirers saw the woman, not the work, are all typical for much of her reception until the present day. Dorothe Engelbretsdatter has had to fight for her place in the literary world from the start. This fight has been twofold: for publication and money,

Sæterbakken and Janike Kampevold Larsen, Oslo 2008). In an almost homonymous book the year after (Den norske littercere kanon 1700-19oo, eds Erik Bjerck Hagen, Jon Haarberg, Jørgen Magnus Sejersted, Tone Selboe and Petter Aaslestad, Oslo 20o9), Dorothe Engelbretsdatter fares only a little better. When five professors of literature select thirteen main authors from the period 1700-1900, the only women are Camilla Collett and Amalie Skram. Engelbretsdatter is, however, mentioned en passant a few times, and given a page in the chapter on hymns, although declared to have written nothing of canonical value, in spite of her importance in literary history (Den norske littercere kanon, 240-41).

2 Her name appears in at least three different versions in her own books, including Dorethe and Dorothea, and she is often called Dorte for short, but Dorothe is the form chosen by her main editor Kristen Valkner.

3 See Laila Akslen's article about her in Norsk Biografisk Leksikon, 2009.

4 "Den mest kjente norske salmedikter fra det 17. årh. var Dorothe Engelbretsdatter, prestedatter og prestekone i Bergen. Hun blev i sin samtid høit beundret selv av virkelige diktere som Kingo, men beundringen gjaldt nok mer prestekonen enn hennes verk. I vår tid må en være litteraturhistoriker for å kunne beundre henne; sprog, tankegang og uttrykksform, alt står så fjernt fra oss. Ganske annen fest er det over Petter Dass, den eneste norske dikter i det 17. årh". (Sverre Steen, Det norske folks liv og historie gjennom tidene: Tidsrummet 1640 til omkring 1720, vol. v, Oslo 1930, 365). [All Norwegian texts are translated into English by me, MNs.] 
but equally for status and recognition. As we shall see, these battles are inseparable in the story of her authorship.

\section{Dorothe's Books}

Unlike her male colleagues who had positions and an income as clergymen or professors, Dorothe Engelbretsdatter was a professional poet since she lived by her pen in addition to a meagre widow's pension. She ridiculed the size of the pension as "a few dozen coins" ("een snees Daler eller toe") in arguing for her need of money. ${ }^{5}$ However, her deepest urge was, evidently, to write. She had written poems since she had become a happy wife and mother, and published her first book while her husband was still alive. Her writing did not at first spring from the need for an income, but from the need to be read. Dorothe wrote religious poetry, hymns, prayers, occasional verse ${ }^{6}$ and verse letters. ${ }^{7}$ She published two main works. Sicelens Sang-Offer (The Song-offering of the Soul) started as a collection of 36 hymns and some other poems in 1678 , but was enlarged with every new edition so that by 1699 it comprised 70 texts. ${ }^{8}$ Its immense popularity and widespread use as a songbook, with printed music included, led to seven editions in her lifetime alone and altogether at least 26 Norwegian and Danish editions over the next two centuries. ${ }^{9}$ She beat, for instance, Thomas Kingo in sales-figures at the time, and his Aandelig siunge-Koor (Spiritual Song-choir) of 1674 and 1681 was a huge bestseller.

Her second work, Taare-Offer (Tear-Offering,1685), stands in a direct intertextual relationship to male predecessors, as parts of it are based on the Danish clergyman Peder Møller's Taare- og Trøste-Kilde (1677), which in itself is a reworking of his German colleague Heinrich Müller's Thränen- und Trostquelle (1675) (both titles mean Source of Tears and Solace). Dorothe Engelbretsdatter takes these devotional texts and turns them into poetry, but she also delivers

5 In a supplication to King Christian v (Kristian Valkner, Dorothe Engelbretsdatter Samlede Skrifter, Oslo 1999, 409).

6 Around 40 are preserved of what was probably a much larger production, perhaps published as leaflets or single sheets.

7 Unpublished at the time, they were circulated in handwritten copies.

8 Dorothe Engelbretsdatter, Dorothe Engelbretsdatters Aandelige Sang og Taare-Offer, Copenhagen 1699 .

9 For further discussion of her seventeenth- and eighteenth-century reception, and the discovery of a circa 175 o copy, see Marie Nedregotten Sørbø, "Travelling Books: When Dorothe Engelbretsdatter Went to America", European Journal of Scandinavian Studies 2 (2017), 291-307. 


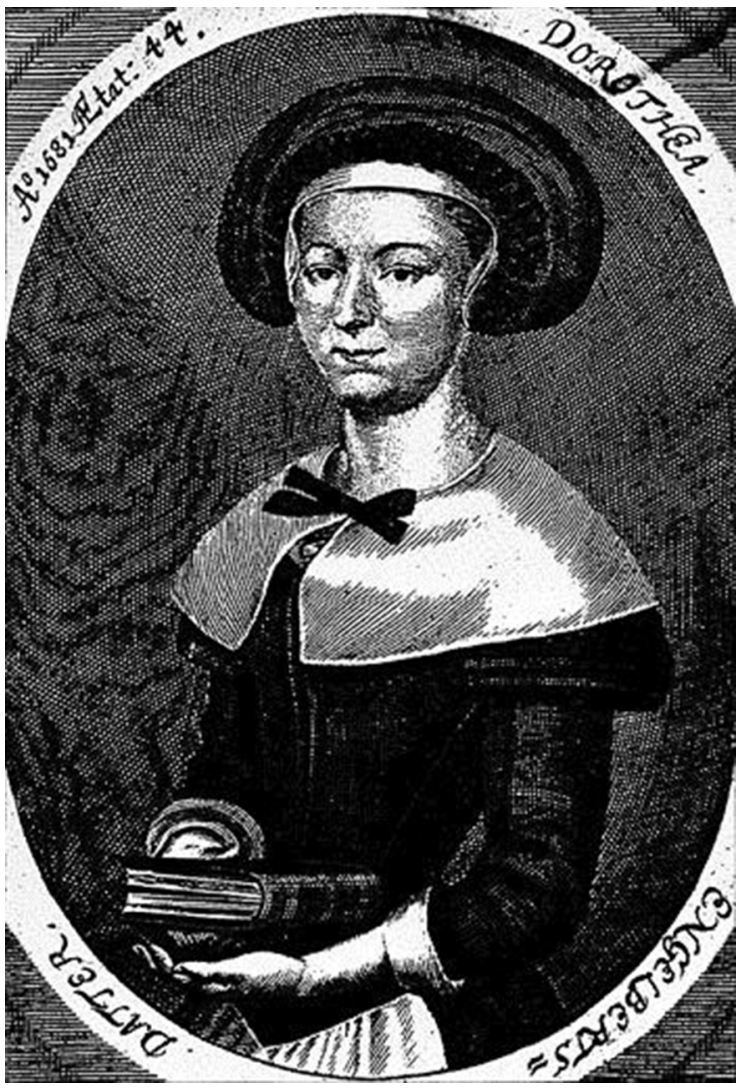

FIGURE 4.1 Portrait of Dorothe, 1681. Store Norske Leksikon, online at https://snl.no/Dorothe Engelbretsdatter

the Biblical material from a different angle. Her emphasis is not on the sinfulness of the prostitute at the feet of Jesus, which tended to fascinate the male authors, but instead on her redemption. ${ }^{10}$

The two collections were later published as one volume in all subsequent editions, and also expanded with other matter, notably the 1698 Et Christeligt Valet (A Christian Valediction). A decade after Dorothe's death Tear-Offering was, as the title informs us, "translated into Swedish verse by a distinguished

10 Inger Vederhus shows that Dorothe Engelbretsdatter reinterprets the figure of Mary the whore as one who is saved and accepted through her tears (Inger Vederhus, "Bold of Pen, Bold in Ink", in The History of Nordic Women's Literature, Copenhagen and Gothenburg 2012, 1993-98). Laila Akslen enters even further into an explication of Dorothe's use of the tears of the female sinner (Laila Akslen, Barokke figurar, Oslo 2008, $14 \mathrm{ff}$ ). 
lady" and published with four copper plate illustrations. ${ }^{11}$ The distinguished lady has been identified as the learned noblewoman Maria Gustava Gyllenstierna, who was a poet in her own right, with around 500 sonnets in addition to other poems.

\section{"Death Is Half My Life"}

Dorothe's two main titles are very suggestive of her entire writing: songs, soul, tears and offerings. "Death (or dead) is half my life" she exclaims in her moving elegy for her husband Ambrosius Hardenbeck, who died before she was fifty. ${ }^{12}$ Part of her battle as an author was her battle against death. She lost seven of her nine children at a young age, all four daughters and three of her five sons. Of the two remaining sons, one died as a soldier and the other disappeared in Leiden (The Netherlands). Her medicine was to turn to poetry. She wrote verse to comfort herself: "New sorrow caused new songs", she explains in her preface. $^{13}$

As it happens, she comforted not only herself, but others as well. Among these was a fellow woman author, Leonora Christina, 13 years her senior, who was incarcerated in a tower in Copenhagen for 22 years because of her husband's political intrigues. ${ }^{14}$ Royal born (daughter of Christian IV) and highly gifted, her marriage in her teens to Corfitz Ulfeldt at first gave her the opportunity to travel and have seven children; then she suffered imprisonment and deprivation. She wrote two books in her prison years, and more of them afterwards, but could not publish in her lifetime, because of her notoriety. Only 200 years later did her prison memoirs Jammers Minde (Memory of Woe) see print (1869). And her collection of female biographies Hceltinners Pryd (The Adornment of Heroines) could comfort only herself by their example, until they finally saw print in the 1970 s. ${ }^{15}$ Leonora Christina found solace in reading

11 Five Swedish libraries still own copies of this translation (Dorothe Engelbretsdatter, TåreOffer, på swenska rim af en förnäm fru öfwersatt, Stockholm 1727).

12 "Død er mitt halfve Lif" (Valkner, Dorothe Engelbretsdatter, 404).

13 "ny Sorg foraarsagede nye Sange" (Valkner, Dorothe Engelbretsdatter, 22).

14 Torill Thorstad Hauger wrote a book connecting the fates of Dorothea, Leonora Christina and Cille Gad, a poet and highly gifted relative of Dorothea's who was condemned to death for killing her new-born child. Her appeal for a reprieve (written in Latin) was granted, allegedly due to her great learning (Torill Thorstad Hauger, I Dorotheas hus, Oslo 1986).

15 Some of these biographical sketches had been lost over time, so the collection is now incomplete. 
Dorothe's poems and expressed her praise in an honorary verse printed in the 1681 edition of The Song-Offering of the Soul: "You Norwegian Torch-Flame and True Tutoress". 16

Dorothe Engelbretsdatter's poems also proved a great comfort to the leprosystricken Ingeborg Andersdotter Grytten, 30 years younger and, like Dorothe, from the West Coast of Norway. She wrote poetry inspired by Dorothe, published a collection called Kors-Frugt (Fruit of the Cross, 1713), and was included in Fr. Chr. Schønau's 1753 Samling av Danske leerde Fruentimmer (Collection of Danish Learned Females), as was Dorothe herself.

In the European context, the year of Dorothe Engelbretsdatter's first book, 1678, is also the year of Madame de La Fayette's (1634-1693) La Princesse de Clèves, marking a new taste for historical and psychological novels. Moreover, Dorothe's fight for her authorship took place at the same time as Aphra Behn (1640-1689) argued for female writing in England. Her play Sir Patient Fancy of exactly the same year contains explicit feminist polemics, as we shall see. ${ }^{17} \mathrm{An}$ other European woman by birth, the New England immigrant Anne Bradstreet $(1612-1672)$ had died a few years before, but the second, authorised edition of her book was published this year, and she also contributed to this querelle des femmes, describing her own battles (see below). ${ }^{18}$

\section{Dorothe's Battle}

The author's preface for Song-Offering bears strong witness to her fight for status. Her self-perception is unashamedly clear. ${ }^{19}$ She calls herself "Bergen's Deborah", after the powerful female judge of the Old Testament, and also refers copiously to other prominent women of the Bible. It is, of course, a way of begging acceptance for her writing: placing herself alongside Biblical models. Moreover, in her poems she argues explicitly for women's right to use the gift that was, after all, given to them by God.

16 "Du Norske Fakkel-Blus og sand Lærmesterinde" (Elisabeth Aasen, Kvinners spor i skrift, Oslo 1986, 30; Dorothe Engelbretsdatter: Tekster i utvalg: salmer, rimbrev og leilighetsdikt, eds Elisabeth Aasen and Egil Pettersen, Bergen 1996, 44-45).

17 It was her seventh play since 1670.

18 The first edition of The Tenth Muse was published by her brother-in-law in London in 1650.

19 In a recent scholarly appreciation of her authorship, Jørgen Sejersted sees this selffashioning as the key to her success. The dialectics between religious self-denial and authorial self-consciousness is a striking feature of her texts and paratexts (Jørgen Magnus Sejersted, "Selvfremstilling i Norges første og største forfatterskap: nyanser i forfatternærvær hos Dorothe Engelbretsdatter og Henrik Wergeland" in Norsk Litterær Årbok (2011), 158-9o. 
Both arguments stand out immediately on opening her first book; in the very first lines she declares herself the female servant ("servantess") of Jesus, and on the second page she asks God to accept her songs like he accepted Mary, Deborah and Hannah. Her extreme humility is no doubt sincere, declaring herself an unworthy sinner, but it is also (she must have been aware) a weighty argument. How can the powerful men of Church and society reject the songs of a pious woman only wishing to praise God? Throughout her authorship she insists on this argument. What she fights for is clearly the right for women to express themselves in print, to be published and read, and to join the discourse of professional authors in its common channels.

After the preface there is an introductory poem - "To the Reader" - where Dorothe Engelbretsdatter enters into theological argument to support her claim to be a published poet. She argues logically that God is the giver of all talents and that she herself has a small talent for writing; should she then bury it? Quite the opposite; talents must be used, she finds. Furthermore, since birds sing and stars shine by God's force, He must even be able to use "a poor female brain". She takes courage from remembering other women God has graced, and there is a second list of Biblical examples. Like so many others, she makes apologies for her lack of formal training, asking the reader to overlook the stylistic faults of "a mere woman", and judge her like a brother would. She begs the reader not be surprised that poor women also want to join in where The Lord's praise is sung; in other words, a direct request for recognition of female creativity and professionalism. She procures the role of professional poet for herself, and paves the way for other women. ${ }^{20}$

Dorothe Engelbretsdatter was never an anonymous lady, nor did she hide behind male pseudonyms. Although her name did not appear on the title page of the first editions, only her initials, it is given in the letter of recommendation from the Bishop of Bergen, and also in her own preface. ${ }^{21}$ The author's gender is not only identified, but always very visible. It is remarkable how the word "woman" keeps reappearing, as if she wants to throw it in the reader's face. It may partly be meant as defence (be patient with a poor woman), but it

$20 \quad$ "En skrøbelig Quinde Hierne"; “Jeg er ickun en Quinde”; "Lad dig og ey forundre det/At Quindfolk som er ringe,/Vil også gierne være med/Hvor Herrens Loff skal klinge” (Valkner, Dorothe Engelbretsdatter, 23-25).

21 The title pages are lost from the early editions digitized by the Norwegian National Library, but according to Valkner, her full name first appeared on the title page of the 1699 edition (Valkner, Dorothe Engelbretsdatter, 533). Her name otherwise appears all over the opening pages (in honorary verses) in all extant editions. Also, her portrait has been included since the beginning, with her own inscription around it (figure 4.1.). 
certainly also served as efficient feminist argument (I have done this, and I am a woman).

Dorothe had lived in Copenhagen, then the common capital of the united Denmark-Norway, for three years in her youth (circa 1647-50). The cultural impulses from the capital may very well have contributed to her poetic ambitions. Certainly, as a clergyman's daughter and from the age of eighteen a clergyman's wife, she was closer to books than most women at the time. Her hometown Bergen was then Norway's biggest and most international city, and approximately half of the population were immigrants from all over Western Europe. ${ }^{22}$ Dorothe's own husband was half German, and German words appear in her poems. ${ }^{23}$

Her twentieth-century editor, Kristen Valkner, claims that she was the first Norwegian author of lasting importance to publish in Norway (rather than Denmark). ${ }^{24}$ The now lost first edition of her first book was published in Christiania (Oslo), and possibly also the next, a now lost pirate edition. Most of the later editions, authorised as well as pirate, were published in Copenhagen. ${ }^{25}$

Dorothe Engelbretsdatter clearly saw herself as a poet with a vocation, but how did others see her at the time? Her battle was also a battle for recognition from readers and colleagues - and she succeeded. She travelled to Copenhagen again in $1684-85$, after her husband's death, and was celebrated at the time as "the first poetess" of Denmark-Norway. ${ }^{26}$ The title was coined, or repeated, by the anonymous writer of an honorary verse printed in her book (in some editions signing himself GMK). He flatters her by pretending that her gifts must belong to a goddess, and concludes that "If you are really only a woman/We will tie you a laurel wreath/And crown you (as reward for your work)/The first poetess". ${ }^{27}$ She obviously liked the honour and also used the title herself. After she lost her house in the great fire of Bergen in 1702, she wrote

22 Elisabeth Aasen gives an illustrated presentation of her life and work in a contemporary context (Elisabeth Aasen, "Dorothe Engelbretsdatter - barokkens Poetinde" in Aasen and Pettersen (eds), Dorothe Engelbretsdatter, 11-61).

23 Ambrosius' poem in German to his 'Geliebte Dorothe' ends her Song-Offering (Engelbretsdatter, Dorothe Engelbretsdatters Aandelige Sang og Taare-Offer, 276-80).

24 Valkner, Dorothe Engelbretsdatter, 12.

25 For textual history, see Valkner, Dorothe Engelbretsdatter, $5 \circ 5 \mathrm{ff}$.

26 Kristen Valkner also comments on the fame she achieved there (Valkner, Dorothe Engelbretsdatter, 305-6). If the first poetess, she was soon followed by others: Elizabeth Pedersdatter Heeboe published Enkens Suck- og Sang-Offer (The Widow's Sighs- and SongOffering) in 1687 (Aasen and Pettersen (eds), Dorothe Engelbretsdatter, 38 ).

27 "Men est Du blot et Kvinde-Kiøn/En Laur-bær Krans vi binde/Og krone dig (dit Verk til Løn)/Den første Poet-Inde" (Dorothe Engelbretsdatter, Sicelens Sang-Offer, Copenhagen $1684,8)$. 
a poetic supplication to King Frederic IV, asking for "a small widow's cottage" for "the first she-poet in The King's countries". ${ }^{28}$ In a dedication for the 1685 edition, she reminds King Christian v "That he in his countries found/the first Bardess". 29

\section{Battling the Trouser Folk}

Being the first professional poetess meant fighting male prejudice as well as male institutions. Still, Dorothe Engelbretsdatter also found ardent supporters among the literary establishment. Among her most eager admirers were two fellow poets, a Dane and a Norwegian, both of whom she met and corresponded with. ${ }^{30}$ Thomas Kingo, a Danish bishop and the most celebrated hymnwriter of the century, was one of the many who wrote honorary verses for her. Born the same year and publishing in the same genre at the same time, they seem kindred spirits. They met at a dinner in Copenhagen, exchanged rhyming compliments, where he named her master of the art. ${ }^{31}$ His praise was profuse and quoted on the frontispiece of several editions: "Who will be surprised that ... the female bardic pen deserves laurel-branches?"32

Dorothea means 'God's gift' and the first part of her surname Engelbretsdatter means 'angel', and Kingo puns on both, gallantly if somewhat feebly. Even taking into account the stylistic as well as emotional extravagancy of the time, the fact remains that Kingo admired her, and welcomed a poetess among the poets. In his long honorary poem for the book he promises that "She shall among bards get a name and seat of honour". ${ }^{33} \mathrm{He}$ pinpoints male prejudice towards female writing:

We men may hitherto have thought

That none but we could crack the little nut

28 "En liden Encke-Høtte"; "Den første Hun-Poet J Arve-Kongens Lande" (quoted in Elisabeth Aasen, Kvinners spor i skrift, Oslo 1986, 33).

29 "Att Hand i sine Lande fant/Den første Skialderinde" (Valkner, Dorothe Engelbretsdatter, 416).

$30 \quad$ Kingo and Dass, however, never met each other (Akslen, Barokke figurar, 131).

31 "Mæsterinden" (Valkner, Dorothe Engelbretsdatter, 432, 553-54).

32 "Hvo vil forundre sig ... At Quindens Skialdre-Pen fortiener Laurbær-greene?" Valkner observes that this verse first appeared in Cassube's pirate reprint of her first book circa 1680, and then authorized in her second book in 1685 (Valkner, Dorothe Engelbretsdatter, 575). "Hun skal blant Skialdrer faa sit navn og ære-sæde" (quoted in Henrik Jæger, Illustreret norsk litteraturhistorie, vol. I, 1896, 237). 
Where hidden lay poetic force and core

But pooh, look now, what woman hits upon. ${ }^{34}$

He went further and playfully suggested that young men who had no taste for learning could swap places with her:

Go take her spinning-wheel you louts,

Who do not want to study,

Start spinning thread and crochet hemp,

While she earns praise with pen and brain. ${ }^{35}$

Although the attitude is probably more carnivalesque than revolutionary, the effect was still a defence of the gifted female poet. It was an enthusiasm shared by his colleague Petter Dass, now the most famous Norwegian baroque poet, but then an unknown clergyman who remained mostly unpublished in his lifetime. Keen to get hold of a copy of Dorothe Engelbretsdatter's book, he wrote a rhymed petition to her while visiting Bergen. She replied - also in verse - that her house was empty of copies, but she was able to reclaim one she had given to a friend, who was instead promised a copy of the forthcoming reprint. The story demonstrates the immediate success of her book. Dass wrote three more entertaining verse letters to her, one of them a complaint that she had not answered his previous ones, provokingly asking if she has lost her rhyming powers.

The two friends may have been of different poetic temperament. As Laila Akslen argues, her attitude seems introvert where his is extrovert. Her poetry was contemplative, subjective, while he was preacher for the people, always instructing. ${ }^{36}$ Nevertheless, they were more alike than different, in their shared fondness for expressing themselves and their faith in rough rhymes and elaborate metaphors. "We will be comrades" she declares in her first answer to his petition, on 2 August 1680, although she knows that she has only "a simple Woman's tongue", and is incapable of "high discourse". This simple woman's discourse is, however, deliberately double: while claiming humility she

34 "Vi Mandfolk hid indtil, maaskee, har haft i Tanke/At ingen uden vi den Nysling kunde banke/Hvori den Skialdre-Kraft oc Kierne proppet laa/Men pyt! See nu kun hvad en Qvinde hitter paa!" (Jæger, Illustreret norsk litteraturhistorie, 237).

35 "Gaar, tager Hendis Rok I Karle-Drøsse-Pinde/Som ey studere vil, begynder I at spinde/ Gaar, setter eder ned at hegle Hamp og Hør!/Mens hund sig priselig med Pen og Hierne giør" (Jæger, Illustreret norsk litteraturhistorie, 237).

36 Laila Akslen, Norsk Barokk: Dorothe Engelbretsdatter og Petter Dass i retorisk tradisjon, Oslo 1997, 220. 
demonstrates mastery. Her well-composed verse is strewn with foreign words from Latin, German and French, ${ }^{37}$ and she cannot help combining a humble bow to her male superiors with a self-confident boast of her own accomplishments: "Even if - between the two of us - I know a little more than The Lord's Prayer, I have to stand aside for the learned ones, the trouser folk take precedence". 38

And they did, also in this case. Comparing the careers and reception of Dorothe Engelbretsdatter and Petter Dass, we are reminded of a pattern in literary canon formation: even once famous women are afforded little space in posterity, and in later reassessments have to give way to men who were once their admirers. (Elizabeth and Robert Browning is another case in point.) In their own lifetime, Dorothe was celebrated and Petter was mainly unpublished. Today, he is selected for two (above mentioned) recent attempts at a Norwegian canon, while she is not.

Another of the canonised men belongs to the next generation: Ludvig Holberg, the most famous Norwegian dramatist before Ibsen. He grew up in Dorothe's neighbourhood in Bergen, was later professor at Copenhagen University, and wrote a book about his hometown in 1737, two decades after her death. Here he admits that Bergen has not fostered many philosophers or literary people, but among the exceptions to this rule there is Dorothe: "Bergen can boast of what no Danish or Norwegian town can show, namely having produced the greatest Poetess that the Nordic countries have had, namely the well-known Dorothea Engelbrechts Dotter". ${ }^{39}$ He remembers seeing Dorothe as an aging woman, dressed in the old costume of Bergen and with a remarkable coiffure, and expresses the utmost respect for her poetic work, which - although not strictly adhering to all "the rules" - is so full of "poetic fertility" that "few Danish poetic works can compare".

37 Dorothe is right in acknowledging her lack of formal education, but the times were improving. The new freedom from Latin meant a chance to write and publish for women without classical training. There is a fascination with the possibilities of the native language in both Engelbretsdatter and Dass, playing with words and ideas that had previously been expressed only in the Biblical languages. It was an age for Bible translations as well as educational texts and poetry in the vernacular.

38 "Vi vil være Camerater [...] J en simpel Qvinde Tunge/Jngen høy Discurs bestaar./Om ieg zwischen uns at sige,/Kand lidt meer end Fader Vor,/Maa ieg for de Lærde viige,/Buxefolket gaar dog for" (Valkner, Dorothe Engelbretsdatter, 398).

39 From Bergens Beskrivelse: "har dog Bergen haft det at berømme sig af, som ingen Dansk og Norsk Stad kand viise, nemlig at den har produceret den største Poetinde, som de Nordiske Riger have haft, nemlig den bekiendte Dorothea Engelbrechts Dotter" (Ludvig Holberg, Den Berømmelige Norske Handel-Stad Bergens Beskrivelse, Copenhagen 1737, 96). 
Dorothe Engelbretsdatter's fame was rooted in both popular and intellectual circles. Her religious motifs as well as her echoes of Norwegian regional accents and daily life secured her immense popularity among the common people. ${ }^{40}$ They are also the reason why she was reprinted at least 15 times in the century proceeding, the Eighteenth, and altogether 26 editions up to the present day. Meanwhile, the admiration and explicit defence that came from important pillars of society and culture must have been instrumental in establishing her reputation as a woman of learning.

"You are an example for our Nordic women" another woman wrote in admiration. She was the first Danish novelist, Anna Margrethe Lasson, signing herself "Aminda" in her honorary poem for Tear-Offering in $1685 .{ }^{41}$ The admiration was mutual and Dorothe addressed "Madame Lassen" as belonging among "the foremost of poets" in a verse letter. Although maintaining that she had not earned such praise, Dorothe accepted the tribute: "if I thus became an example for women". ${ }^{42}$ Dorothe's contemporary status as an important literary figure is solid. It was won through insistent arguments and fierce fights.

\section{Controversies: Accusations of Plagiarism}

We now come to the other side of the coin; Dorothe Engelbretsdatter may have had fame, but she also faced resistance. Controversies came from two quarters: arrogant academics and pirate publishers. Some students in Copenhagen (whose university also catered for Norway until the Nineteenth Century) accused the author of plagiarism and theft of texts. The first accusation came almost immediately upon publication of the second edition, as witnessed by Joachim Kaae, himself a student at the time: "one heard then many [...] give censure and ascribe it not to Dorotheæ herself, but to her husband who was alive at the time". He then recounts (in verse) how he could disprove the charge, because he himself had made the fair copy of the book for printing. He

40 She repeatedly insisted on her Norwegian origin and identity in her texts, and also employed a large number of Norwegian words and forms in her use of the official Danish language (see Egil Pettersen, "Språket hos Dorothe Engelbretsdatter" in Aasen and Pettersen (eds), Dorothe Engelbretsdatter). Modern readers can easily recognise the Bergen dialect in her writing.

41 "Du et Exempel er for voris Nordens Qvinder". Lasson was the author of the 1723 Den Beklcedte Sandhed (The Clothed Truth, quoted in Valkner, Dorothe Engelbretsdatter, 420). Her classical taste in pseudonyms is a mannerism of the time, and reminds us of Katherine Philips' "Orinda".

"Blef ieg paa den maneer for Qvinder et eksempel" (Valkner, Dorothe Engelbretsdatter, 420) 
attributes the accusations to "envy", and finishes with some angry lines about "nasty insinuations". 43

Another defence is implicit in her son's tribute, included among the many honorary verses in the beginning of the book: "my virtuous mother/she who has written this book". ${ }^{4}$ Not to mention her husband's two-page homage to his wife's art, which ends the collection. ${ }^{45}$

It was not the only charge, another attack came from a student who could reveal that Dorothe Engelbretsdatter's work was not original, but had been published in devotional books a century before. Dorothe responded in kind. She was not one to sit still and suffer such false accusations against her writer's honour. Several of her verse letters reflect the conflict, and some are addressed to the student(s) in question: "To the old student Jacob Hassebart" she writes mockingly of his little courage, his empty purse and his friendliness with the bottle. In "Recipe for a Ranter" she repeats the accusation against her "that I reheated hymns" from old hymnbooks, which would remain a lie "even if he could shit gold and pee white cinnamon-water". She recommends extreme measures: "Claus Clown should be castrated". 46

This coarse counter-attack is perhaps not quite what we expect from a female hymn-writer with two volumes of pious verse. Dorothe Engelbretsdatter was not, however, a nineteenth-century hymn-writer, but a seventeenth-century one, of the same making as John Donne (who found rape an appropriate metaphor for divine action). They have the same taste for mixing the high and the low, the heavenly and the earthly.

The slandering students seem to have had some effect: "Some people swallow such wisdom", she notices herself. ${ }^{47}$ And Kaae, as we saw, heard "many" people repeat it. Dorothe is clearly anxious of "the doom felled by the world" even if she knows that "My work is clear to God". 48

43 "da hørte mand vel mange, [...] At give hver Censur, eendeel det at tilskrive/Ej Dorotheæ selv; Men Manden som i Live/Paa den tid var"; "Afvind"; "saadan Skumleri" (from an honorary poem included in the 1699 edition, quoted in Valkner, Dorothe Engelbretsdatter, $\left.5^{28}\right)$.

44 "Min Dydefulde Moder/Hun som har Skrefvet denne Bog" (Engelbretsdatter, Dorothe Engelbretsdatters Aandelige Sang og Taare-Offer).

45 See footnote 23 above.

46 "Til en gammel Student Jacob Hassebart"; "Recept for en Ord-Gyder”; "opvarmed Salmer"; "Om schiønt hand kunde skide Guld/Og hvidt Canel-Vand pisse”; "Claus Nar bør Castereris" (Valkner, Dorothe Engelbretsdatter, 446-48).

47 "Slig Klogskab some sluger ind" (Valkner, Dorothe Engelbretsdatter, 448).

48 "Hvad Domme Verden felder; "Mit Verck for Gud er Aabenbart" (Valkner, Dorothe Engelbretsdatter, 448). 
The attacks were firmly founded on male prejudice against female writing. One attacker, the poet Tøger Reenberg, made polemic verses about how "men are always better fit to write verses and ride horses and show courage at war, which is no honour for women". ${ }^{49}$ Like so many other women writers, Dorothe Engelbretsdatter and her contemporaries had to fight such notions about the female intellect, or brain, as she refers to it. ${ }^{50}$ Anne Bradstreet complained of the same. In "The Prologue" to her book she declares "I am obnoxious to each carping tongue/Who says my hand a needle better fits/A poet's pen all scorn I should thus wrong/for such despite they cast on female wits". We notice she has also met the accusation of theft ("They'll say it's stolen").51

Aphra Behn expressed similar frustrations, for instance, in the Epilogue of Sir Patient Fancy (1678). After the action is over, her narrator steps onto the stage and confronts the audience with their prejudices: "I here and there o'erheard a Coxcomb cry/Ah, Rot it - 'tis a Woman's Comedy [...]". She embarks on a long speech of defence for the female intellect: "What has poor Woman done that she must be/Debar'd from Sense and sacred Poetry?" She sharply ridicules male weaknesses, and male classicist drama, and provokingly claims that women "could write/Equal to Men; cou'd govern, nay cou'd fight", a claim she also repeats in the last line of the play: "pray tell me then/Why Women should not write as well as Men". ${ }^{2}$ Like Dorothe Engelbretsdatter, she confidently uses her own work as proof of her point. Clearly, Anna Margrethe Lasson was right when she observed (in her verse to Dorothe) that many people "doubt that this sex can possess this gift". 53

49 "At skrive Vers, at ride Hest/I Krigen modig være/det stedse sømmer Manden best/er Quinden ingen Ære" (Laila Akslen and Inger Vederhus, "Etterord til 1999-utgåva" in Valkner, Dorothe Engelbretsdatter, 583-95, 592).

$50 \quad$ Kristen Valkner thinks that the newness of a woman producing a major poetic work was at least part of the cause (Valkner, Dorothe Engelbretsdatter, 11). Laila Akslen Kvalbein observes that "What caused contemporary and later controversies around Dorothe and her poetry was to a large extent that she dared grip the pen and compete with the most renowned male poets. And moreover, she also managed to put a sharp and deliberate feminine imprint on what she wrote, an imprint that bothered and annoyed a lot of people at the time". ("Det som gjorde at det vart strid om Dorothe og diktinga hennar alt i samtida og den nære ettertida, var mykje det at ho som kvinne torde gripe til pennen og ta opp konkurransen med dei gjevaste mannlege diktarane. Og ikkje nok med det, ho makta også å setje eit skarpt og medvite kvinneleg stempel på det ho skreiv, eit stempel som generte og irriterte svært mange den gongen”.) (Laila Akslen Kvalbein, Feminin barokk: Dorothe Engelbretsdotters liv og diktning, Oslo 1970, 17).

51 The Norton Anthology of American Literature, 6th ed., Vol. A, ed. Nina Baym, New York and London 2003, 239.

52 The Works of Aphra Behn 4, 1915, 115-16.

53 "tvifler, dette Kiøn kand eye denne Gave" (quoted in Aasen, Kvinners spor i skrift, 32). 
Later literary historians came up with similar accusations; in the early Twentieth Century the argument against Dorothe Engelbretsdatter was that she had copied Thomas Kingo, based on certain similarities between their texts. The editor of her collected works, Kristen Valkner, meticulously researched the alleged loans, and concluded that the similarities were slight, and always a result of shared ideas and images of the time, which would be found in any writer. ${ }^{54}$ The allegations had also much earlier been refuted in Norsk Salmehistorie (Norwegian hymn history), where editor J.N. Skaar pointed to textual and biographical evidence that most of Engelbretsdatter's poems in Song-Offering were in fact older than Kingo's hymns. ${ }^{55} \mathrm{He}$ finds her to be mainly influenced by the predominant German hymn-tradition, which she knew from a life in the church, and which must be where she got her sense of poetic form.

The controversy also had a clear gender bias, with gender battles being fought. Dorothe Engelbretsdatter's somewhat irreverent name for the male part of the population was "the trouser folk" or even "trouser trolls" ("Buxefolket", "Buxe-Trold"). It is, of course, an example of the typical baroque taste for periphrasis, where elaborate evasions substitute the simple word. The parallel for women is for instance "ewe-lambs" ("Gimmer-Lam") or "the linen" ("Lintøyet"). ${ }^{56}$ More than this, the concept indicates a certain nonchalance, and an awareness that she is a female poet and different from the trouser folk. There is a striking mixture of submission and self-confidence in her attitude to them. She combines explicit humility with implicit pride and craving for the right to write, like Bradstreet and Behn. She claimed her place and beckoned women to follow her: "The ewe-lamb is not ashamed, even if - between us - it is a little forgotten. When the trouser-folk brag and boast, should we therefore yield?"57 The answer is a clear no, and she argues that God has his own school for "the weak female gender, whose brain is made like a son's". ${ }^{8}$

What Engelbretsdatter achieved by not yielding was a feminine form of baroque. This is also the main conclusion of Laila Akslen Kvalbein's study of her texts. The author did not dare disturb the main genres and forms of poetry, since to be a professional woman poet was disruption enough. She was not inventive or avant-garde, and instead worked within inherited forms and the

54 Referred to in Inger Vederhus, Engelbretsdatterstudiar, Bergen 1982, $82 \mathrm{ff}$.

55 J.N. Skaar, Norsk Salmehistorie 2, Bergen 1879-80, 583 .

56 Akslen Kvalbein, Feminin barokk, 114.

57 "Gimmer-lam er icke skemt,/Blef end lit paa dennem glemt,/Mellom os at Sige,/Huor af buxe-folcked vill,/Giøre sig for meget till,/Bør Vj derfor Vige?" (Valkner, Dorothe Engelbretsdatter, 439).

$5^{8}$ "Gud har og sin scholle/For det suage quinde Kiøn/Skabt I Hiernen som en Søn/Derpaa bør vi stole” (Valkner, Dorothe Engelbretsdatter, 439). 
poetic taste of the day. However, her use of those forms was clever, her poems striking and her figure in contemporary society important. Her feminine contribution to poetry took at least three major directions. She introduced female interests and imagery into a male world, such as the pleasure in jewellery. ${ }^{59}$ She wrote about (and for) mothers and widows and Christian women. And she insists throughout her work on her own femininity, down to the details of grammar: always calling herself "poetess" not poet, always adding the feminine suffix "-inde" (-ess) to all possible or impossible nouns, like servant, worker, bard, singer, sinner, and disciple. ${ }^{60} \mathrm{I}$ also noted above how she keeps foregrounding the word "Quinde" (woman). Dorothe Engelbretsdatter never puts her candle under a bucket, but always lets it shine proudly: arguing theologically with men, seeing herself as proof that women should be allowed to write.

\section{Controversies: Piracy and Copyright}

The second main controversy surrounding Dorothe Engelbretsdatter, in addition to the suspicions raised by her gender, is the battle with publishers. Two of the early editions of The Song-Offering of the Soul - the second and the third were pirate versions, and Dorothe Engelbretsdatter was deeply frustrated by the inaccuracies and lack of respect for her authorial rights. In a preface to the reader in her own second edition of 1681 , which was really the fourth to be published, she complains that "a greedy, vicious, impertinent person, who dares not proclaim his name, ${ }^{61}$ could find it in his heart, for the sake of perfidious profit, to reprint the book, in swindler's manner". ${ }^{62}$ She goes on to describe the omissions and mistakes.

Clearly, it annoyed her that while she herself had paid for the first edition and had printed only few copies, which she had given out for free among rich and poor, other people should try to cash in on her immediate success. ${ }^{63}$ What

59 Akslen Kvalbein, Feminin barokk, 63ff, 85. In one poem she uses the larder as an image for the Last Supper ("Saa det Spise-Kammer/Slugte all din Jammer"), in a metaphysical conceit worthy of a female John Donne. It is as if a modern poet said of Holy Communion that "this fridge satisfies all your yearnings" (Valkner, Dorothe Engelbretsdatter, 131).

6o Akslen Kvalbein, Feminin barokk, 67 .

61 She seems to be thinking of the second edition, since the third carried Cassube's name.

62 "at it glubsk, vanartig, u-forskammed Menniske, der icke tør være Nafned bekiendt, understood sig, for slem Vindings skyld, at trycke Bogen effter, paa Fuskerviis" (Valkner, Dorothe Engelbretsdatter, 212).

63 "paa egen Bekaastning"; faa Exemplarier som blant Venner Rig og Fattig, uden Nøttesøgelse, er ud-deelt' (Valkner, Dorothe Engelbretsdatter, 212) 
really enrages her to the extent of abusing her pirates is the fact that these editions, particularly the second, were faulty, and gave the wrong impression of her poetic abilities. In addition, the printed music was missing. It worried her that the buyers would get poor value for their money, and she strongly recommends her readers to stick to the first or the new fourth edition. The others are "bastard foetuses".64 "I do not recognise other books" is a strong declaration of the rights of authorship, especially coming from a woman, and at the beginning of her career. Dorothe Engelbretsdatter fought for her books from the start. ${ }^{65}$

She also composed a counter-attack in the form of a verse lampoon, although this was not published. Here she suggests that somebody lend the thieving printer a pair of glasses so that he can render her poetry better the next time the greed for money grips him. ${ }^{66}$ She said worse things, and in these cases the lines are virtually dripping with contempt in words such as "shameless", "long-fingered", "gallows-food". In a verse letter she defends her harshness: "A mother must have the right to complain when her foetus is attacked".67

Dorothe Engelbretsdatter was granted a kind of early copyright as a reward for her struggles: a royal licence to control the publishing of her books for ten years, later renewed for ten more (figure 4.2). In 1682, the publisher of the unauthorised editions, Christian Cassube, was heavily fined, although this seems not to have hurt him much. Cassube's thriving book business and increasing monopoly in both countries made him rich enough to lend the state money. ${ }^{68}$ The controversy demonstrates Dorothe Engelbretsdatter's saleability and market value as well as her professional and self-confident attitude and behaviour.

Several of her counter-attacks are found in her verse letters, a genre much exploited in her circles. She also addressed The King with rhymed letters of petition, where we see that she had financial battles to fight as well. She explains that she has "little money, not much in the larder, and no fields or harvests", and names her small yearly income as a clergyman's widow. She is as "terrified of the executor [tax collector] as of the bogey-man himself" (written in 1684) ${ }^{69}$

64 "u-æcte Fostre". Valkner comments that the word "foster" (foetus) was then also used for children after birth (Valkner, Dorothe Engelbretsdatter, 213, 543).

65 "Jeg kiendis icke ved andre Bøger" (Valkner, Dorothe Engelbretsdatter, 213).

66 "At vende Versen op og need/Og riime efter galne griller/Kand ingen laane dig to briller/ At see hereefter bedre til/Og læse over om du vil/Saa du i Konster ej fallerer/Naar PengeSoeten opererer" (Valkner, Dorothe Engelbretsdatter, 401).

67 "En Moder faar jo klage sig/Hvis Foster mand angriper" (Valkner, Dorothe Engelbretsdatter, 403).

68 Vederhus, Engelbretsdatterstudiar, 88.

69 "Jkke har jeg mange Penge/Jkke gaar Forraadet højt/Jngen Agre heller Enge/Jngen Jindkomst for en Døyt ... Aarlig Nøed Pastorens Enkke/Een Snees Daler eller toe/... Jeg naar 


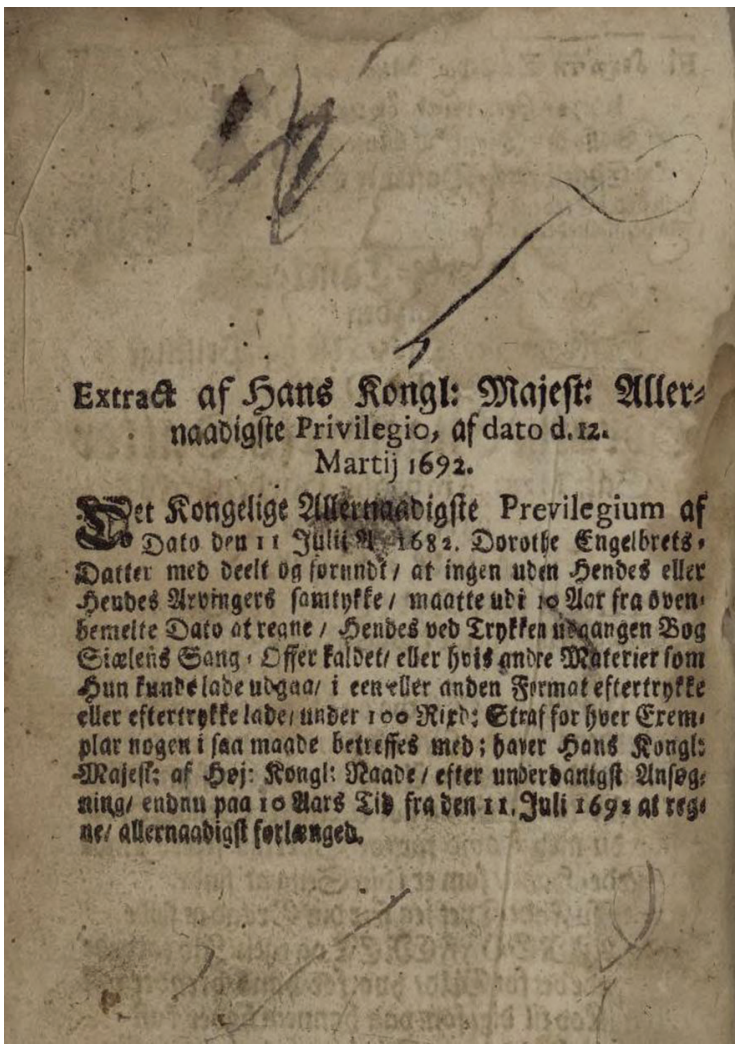

FIGURE 4.2 The Royal Letter allowing Dorothe to have a copyright on her work, 1682, revised 1692. The Norwegian National Library's digitized editions of Dorothe Engelbretsdatter's books, 1706 edition.

Interestingly, she uses the same argument Virginia Woolf based A Room of One's Own on around 250 years later: financial security is the key to the creative process. The King holds "my key to poetry/to open or lock". When he was graceful, "the rhyme-bag sprung open where before it was dormant". Like Woolf, Engelbretsdatter needs a certain sum of money and a room of her own: "The Ink-brush demands quiet". ${ }^{70}$ She explicitly does not expect affluence, just

Angsten dominerer/J mit Hovet som een Elf/Er saa red for exequerer/Som for BusseManden self" (Valkner, Dorothe Engelbretsdatter, 409).

70 "Ham var med skyldig Fryct min Dicte-Nøgel Ragt/At Aabne og sla til Stood i Monarkens Mact./Strax hand kun Naade-Fuld saa Trøstig ord gad tale,/Sprang Rime-posen op der Half-Død laa i dvale,/Blek-Penslen fodrer Roo, Prakt giver jeg forlov,/Har dog i midler Tid Lifs underhold behov" (Valkner, Dorothe Engelbretsdatter, 411). 
subsistence, so that she has the necessary peace to write. ${ }^{71}$ In her next letter, to Queen Charlotta Amalia, she thanks her profusely for having intervened with The King and "released me from my burdens". ${ }^{72}$ When King Christian v died, she wrote to his son, the new King Frederic IV in 1700, in the hope that he would continue supporting her writing "after the simple womanly talent". We also notice that she refers to her work as a "duty to write". ${ }^{73}$ To oil the machinery, she sent poems in praise of both the deceased and the new king.

Dorothe Engelbretsdatter was awarded tax relief for life. She clearly fought for the right to support herself as a widow, as an alternative to the common solution of remarrying another clergyman after her husband died. Instead of re-entering the marriage-market, she argued for her livelihood as a writer. "She recognised early on that the status of 'Poetess' gave her a unique commercial lever in her contemporary society". ${ }^{74}$ The tax relief was in reality a form of author's stipend, and it made Dorothe Engelbretsdatter effectively the first Norwegian writer to receive such support.

\section{Last Battles}

One of the last battles old Dorothe had to fight was for a room of her own, or more precisely a "small widow's cottage", after the great 1702 fire of Bergen had destroyed her house along with most of the city. It was actually the fifth big fire in Bergen in her lifetime, and the second time her own home was lost. As usual, she resorts to her pen and her "rhyme-bag" and sends a humorous, but heartfelt appeal to three important men of the city. She points out that she is now in "Number Nil", seemingly housed in an alms-house among the poor. She is like a bird without a nest, ashamed of begging, but soon to die, self-ironically "full of sighs and old coalfish". She presents herself as the forgotten poet whose talent is being reduced to crumbles, in spite of the popularity of her books. "Bergen's Deborah perceives that the Trouser-folk have forgotten the poor one". ${ }^{75}$

Appeals over the years to King and city at last paid off and she got a new house, and hopefully some peace in her final years. Unfortunately, since it took

$71 \quad$ All quotations are from her second letter to King Christian v in 1684, the year she went to Copenhagen.

72 "mig fra byrder løst" (Valkner, Dorothe Engelbretsdatter, 413).

73 "i lige Maade Anno 1700 naadig anseer min dybt underdanigste SkrivePligt, stiiled efter det kleinlige Qvinde-Pund" (Valkner, Dorothe Engelbretsdatter, 478).

74 Vederhus, "Bold of Pen, Bold in Ink".

75 "Nu mig Nummer Nix voldgiester"; "Met af Suck og gammel Sey"; "Bergens Debora fornemmer/Buxefolck den stachel glemmer" (Valkner, Dorothe Engelbretsdatter, 498-99). 
ten years to provide her with a permanent home, she only had six years to enjoy it. In one of the many ironies of history, the house has later been proudly shown off as "Dorothe Engelbretsdatter's house", part of The Museum of Old Bergen.

In true baroque manner, like John Donne sitting for his death mask, she wrote her own funeral hymn, just leaving the year open. ${ }^{76}$ Here she expresses her loneliness and hard life, and the sense that death is a release from all troubles. Through all pious hopes and humble submission, the most striking line is the very last one; she is going "Where husband and children embrace me".77 She must have been a lonely, old woman, having lost nine children and a much-loved husband, and having to beg the city authorities to look after her. She remembers the pleasures and merriment of the past, of the happy days when she "feasted on joy", and "opened" her "rhyme-bag" for fun. "But since, worries have scourged my joy/And death has penetrated the windows." 78

When later nineteenth-century critics found her poetry maudlin they seem not to have grasped the conditions of her life and times - a time of pestilence and poverty - from the comfort of their plush, pompons and pipe-smoking, their time of high production and optimistic progress. Nor did they comprehend the baroque taste for personal emotion and extravagant expression, or her striking self-irony. She did not fit in with nineteenth-century order and moderation. The influential literary historian Nordahl Rolfsen is a case in point. Although awarding her a place in his canon of Norwegian poets, incorporating her portrait and six poems, he still mainly expresses annoyance at her tearfulness: "the reader" is "drowning" and "gasping for air" in all this water. Moreover, he objects to her tactless style in writing of "whore-houses" and "maggot-sacks". 79

Around 340 years have passed since Dorothe Engelbretsdatter published her first book, with a contemporary best-seller status that subsequently

76 She marks the expected year of death as "17onb", while she actually lived until 1716.

77 "Hvor mand og børn mig fauvner" (Valkner, Dorothe Engelbretsdatter, 502).

78 "I Glæden Grasseret"; "Men siden bekymring min Glæde Hudflenget/Og døden sig igienum Vindverne trenget" (Valkner, Dorothe Engelbretsdatter, 467-68). After studying the author's revisions in the various editions of Sicelens Sang-Offer, Akslen Kvalbein comments that she changed after the death of her husband. She expands the genre of "Sighs" for morning and evening use for all days of the week, and her titles are full of widowhood, grief and farewells to the world (Akslen Kvalbein, Feminin barokk, 120).

79 Nordahl Rolfsen, Norske digtere: fra Petter Dass til vore Dage, Bergen 1886, 22-30. Twenty years earlier, in a history of Norwegian poetry, the tone is more balanced, but her poetry is seen as "rhymeries" (L. Dietrichson, Omrids af den norske Poesis Historie 1, Bergen 1866, 69-76). 
endured in the following two centuries. ${ }^{80}$ She was, however, increasingly seen as old-fashioned, and moreover, as too crude and coarse in her expressions, too tearful and emotional in her attitude, and, I suspect, too direct in her female demand for recognition and her conscious poetic voice. ${ }^{81}$ Her fight for professional status as a major poet has not always been successful. ${ }^{82}$

Nevertheless, she has also in modern times been represented by a few poems in official hymnbooks for Norwegian church use. The most influential one of the late Nineteenth Century and much of the Twentieth was M.B. Landstad's hymnbook, and he specifically argued that since she had been so widely loved by the public, she deserved a place in the canon. He deliberately transplanted her from the cottages to the churches, and thought she would not shame them. ${ }^{83}$ One and a half centuries later, one of her songs remains in the new hymnbook for The Norwegian Church. ${ }^{84}$

She is at present commonly taught in schools, and included in Norwegian textbooks. YouTube turns up examples of school projects where young voices read or dramatise her. A prize-winning children's author wrote a personal account of her life and times based on her house. ${ }^{85} \mathrm{~A}$ novel of academic satire describes a professor of literature tracing unknown love-letters between her and Dass, in his eagerness to supervise a young woman who wants to write her thesis on Dorothe. ${ }^{86}$ Engelbretsdatter has also occasionally been introduced

8o In a register of books mentioned in settlements of estate in four Norwegian regions between 169 o and 1839, Dorothe Engelbretsdatter is found in all regions. Although she is by far outnumbered by her friends Dass and Kingo, who authored standard catechisms and hymnbooks to be found in most homes, she is among the more common of the other authors (Jostein Fet, Lesande bønder, Oslo 1995, 345). The author Kristofer Janson noticed a small revival for her and other such "dusty old books of devotion" since they had been recommended by the popular spiritual leader Hans Nielsen Hauge in the first part of the Nineteenth Century (quoted in Fet, Lesande bønder, 194).

81 In a major 1896 literary history her second book is described as "tasteless and banal" ("smagløst og banalt") and a "tearjerker" ("Taare-perse"), although the author also acknowledges her longstanding fame as "the great poetic light" who "struck chords which are still resounding" (Jæger, Illustreret norsk litteraturhistorie, 232-40).

82 By the early Twentieth Century, her books had disappeared from the shelves of, for instance, the women's reading society in the Norwegian capital, and only a small booklet on her authorship is found in the collection (see Marie Nedregotten Sørbø, "Elusive Women Authors in Norwegian Nineteenth-Century Reading Societies", in NORA 24/4 (2017), 279-95.

83 Quoted in Skaar, Norsk Salmehistorie, 587 and in Jæger, Illustreret norsk litteraturhistorie, 236.

84 It is her most popular evening song: "Dagen viker og går bort" ("The day is yielding and departs", or in Grove's translation: "Day is dwindling, then is gone"), in a somewhat modernized version (Norsk Salmebok: for kirke og hjem, Stavanger 2013, 929-30, No 810).

85 Hauger, I Dorotheas hus, 1986.

86 Henrik Langeland, Francis Meyers lidenskap, Oslo 2007. 
abroad. In an American canonisation of Norwegian authors, she is presented twice, in the chapter on the baroque period, and in Faith Ingwersen's chapter on women writers. ${ }^{87}$ While Sarah J. Poulson's introduction to Dorothe Engelbretsdatter's work for foreign students of Scandinavian literature interestingly also includes three translations into English by Leslie Ann Grove. ${ }^{88}$ More translations are found in Gracia Grindal's thorough chapter on her authorship. ${ }^{89}$ And although Dorothe Engelbretsdatter may not have seen much translation a hundred years ago, she was still awarded a decent entry in one of the world's main reference works, Encyclopedia Britannica, in $1911 .{ }^{90}$

Her name has always lingered in the corners of literary histories, even if canon-makers as recently as 2007 and 2009 overlooked her. Like her fellow poets Anne Bradstreet and Aphra Behn, Dorothe Engelbretsdatter wrote appeals for the acceptance of the woman writer. Moreover, Behn and Engelbretsdatter both lived by their pen, setting early examples of professional female authorships. Through fighting for her livelihood as well as her reputation, Dorothe Engelbretsdatter remains a strong voice in Scandinavian literature. The need to earn money and the need to be recognised are equally urgent. Modern readers do not, however, often get a chance to hear that voice. Although there have been two twentieth-century editions of her poetry, one of collected and one of selected poems, there are no books by her in Norwegian bookshops at present. The battle therefore still goes on.

\section{Bibliography}

\section{Primary References}

Aasen, Elisabeth and Pettersen, Egil (eds). 1996. Dorothe Engelbretsdatter: Tekster i utvalg: salmer, rimbrev og leilighetsdikt. Bergen: Eide Forlag.

Behn, Aphra. 1915. The Works of Aphra Behn. Vol. Iv. Montague Summers (ed.). Online at: http://www.gutenberg.org/files/27273/27273-h/patient.html\#patient_epi (consulted 25.02.2014).

Engelbretsdatter, Dorothe. 1684. Sicelens Sang-Offer. Copenhagen. Online at: http://

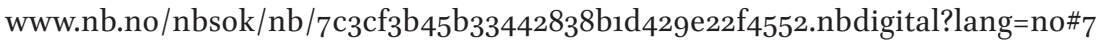
(consulted 24.02.2014).

87 In Harald Naess, A History of Norwegian Literature, 1, Nebraska 1993, 50-51, 353.

88 In Female Voices of the North, 1, eds Inger M. Olsen and Sven Hakon Rossel, Wien, 2002, 117-132.

89 Gracia Grindal, Preaching from Home, Grand Rapids, 2011.

$90 \quad$ "Engelbrechtsdatter, Dorthe" in Encyclopedia Britannica, Vol. 9, 1911. 
Engelbretsdatter, Dorothe. 1699. Dorothe Engelbretsdatters Aandelige Sang og TaareOffer. Copenhagen: Joachim Schmedtgen. Online at: http://www.nb.no/nbsok/nb/ o63o8a33ee2da2126bbfb52f5fdd2af6.nbdigital?lang=no\#o (consulted 24.02.2014).

Engelbretsdatter, Dorothe. 1727. Tåre-Offer, på swenska rim af en förnäm fru öfwersatt (tr. Maria Gustava Gyllenstierna). Stockholm: Joh. Laur. Horrn.

Valkner, Kristian. 1999. Dorothe Engelbretsdatter Samlede Skrifter. Oslo: Aschehoug.

\section{Secondary References}

Aasen, Elisabeth. 1986. Kvinners spor i skrift. Oslo: Det Norske Samlaget.

Aasen, Elisabeth. 1996. 'Dorothe Engelbretsdatter - barokkens Poetinde' in Aasen, Elisabeth and Pettersen, Egil (eds), Dorothe Engelbretsdatter: Tekster i utvalg: salmer, rimbrev og leilighetsdikt. Bergen: Eide Forlag: 11-61.

Akslen Kvalbein, Laila. 1970. Feminin barokk: Dorothe Engelbretsdotters liv og diktning. Oslo: Universitetsforlaget.

Akslen Kvalbein, Laila. 1997. Norsk Barokk: Dorothe Engelbretsdatter og Petter Dass $i$ retorisk tradisjon. Oslo: Landslaget for norskundervisning (LNU)/Cappelen Akademisk Forlag.

Akslen Kvalbein, Laila. 2008. Barokke figurar. Oslo: Laila Akslen.

Akslen Kvalbein, Laila. 2009. 'Dorothe Engelbretsdatter' in Norsk Biografisk Leksikon (consulted o9.02.2018). https://nbl.snl.no/Dorothe_Engelbretsdatter

Akslen, Laila and Vederhus, Inger. 1999. 'Etterord til 1999-utgåva' in Valkner (1999): 583-95. Baym, Nina (ed.). 2003. The Norton Anthology of American Literature (sixth ed. Vol. A). New York, NY, and London: W.W. Norton \& Company.

Dietrichson, L. 1866. Omrids af den norske Poesis Historie. Vol. I. Copenhagen: Gyldendal. Online at: http://www.nb.no/nbsok/nb/b7oc698087270co784cfo87fda792298. nbdigital?lang=no\#87 (consulted 26.02.2014).

Encyclopedia Britannica. 1911. 'Engelbrechtsdatter, Dorthe' in Vol. 9 (consulted o9.02.2018). https://en.wikisource.org/wiki/1911_Encyclop\%C3\%A6dia_Britannica/ Engelbrechtsdatter,_Dorthe

Fet, Jostein. 1995. Lesande bønder. Oslo: Universitetsforlaget.

Grindal, Gracia. 2011. Preaching from Home: The Stories of Seven Lutheran Women Hymn Writers. Grand Rapids and Cambridge: Eerdmans.

Hagen, Erik Bjerck, Haarberg, Jon, Sejersted, Jørgen Magnus, Selboe, Tone, and Aaslestad, Petter. 2009. Den norske littercere kanon 1700-19oo. Oslo: Aschehoug.

Hauger, Torill Thorstad. 1986. I Dorotheas hus. Oslo: Gyldendal Norsk Forlag.

Holberg, Ludvig. 1737. Den Berømmelige Norske Handel-Stad Bergens Beskrivelse. Copenhagen: J.J. Høpffner. Online at: http://da2.uib.no/cgi-win/WebBok.exe?slag=lesbok\&bokid=bgbeskriv (consulted 24.02.2014).

Jæger, Henrik. 1896. Illustreret norsk litteraturhistorie. Vol. 1. Online at: http://urn.nb. no/URN:NBN:no-nb_digibok_2009051210001 (consulted 27.02.2014). 
Langeland, Henrik. 2007. Francis Meyers lidenskap, Oslo: Tiden Norsk Forlag.

Naess, Harald S. (ed.). 1993. A History of Norwegian Literature. Vol. II. Nebraska: University of Nebraska Press.

Norsk Salmebok: for kirke og hjem. 2013. Stavanger: Eide forlag.

Pettersen, Egil. 1996. 'Språket hos Dorothe Engelbretsdatter' in Aasen, Elisabeth and Pettersen, Egil (eds), Dorothe Engelbretsdatter: Tekster i utvalg: salmer, rimbrev og leilighetsdikt. Bergen: Eide Forlag: 19o-213.

Poulsen, Sarah. 2002. 'Dorothe Engelbretsdatter', in Female Voices of the North, eds Olsen, Inger M. and Rossel, Sven Hakon, Vol. I. Wien: Edition Praesens.

Rolfsen, Nordahl. 1886. Norske digtere: fra Petter Dass til vore Dage. Bergen: Ed. B. Gierstens Forlag. Online at: http://www.nb.no/nbsok/nb/8e $7 b_{75} f_{5} 63 c 6 b b d 50 b d e 75 a-$ cac195163.nbdigital?lang=no\#3 (consulted 28.02.2014).

Sejersted, Jørgen Magnus. 2011. 'Selvfremstiling i Norges første og største forfatterskap: nyanser i forfatternærvær hos Dorothe Engelbretsdatter og Henrik Wergeland' in Norsk Littercer Årbok: 158-9o.

Skaar, J.N. 1879-8o. Norsk Salmehistorie. Vol. II. Bergen: Beyer. Online at: http://www. nb.no/nbsok/nb/2db5517df85od15fd $3 \mathrm{Cl}_{753} \mathrm{fi}_{16872735}$.nbdigital;jsessionid $=5921 \mathrm{C}$ BA8F373D5oAB70316oCC3FE3669.nbdigital2?lang=en\#587 (consulted 28.02.2014).

Sørbø, Marie Nedregotten. 2017a. 'Travelling Books: When Dorothe Engelbretsdatter Went to America' in European Journal of Scandinavian Studies 2: 291-307.

Sørbø, Marie Nedregotten 2017b. 'Elusive Women Authors in Norwegian NineteenthCentury Reading Societies' in NORA 24(4): 279-95.

Steen, Sverre. 1930. Det norske folks liv og historie gjennom tidene: Tidsrummet 1640 til omkring 1720. Vol. v. Oslo: Aschehoug.

Sæterbakken, Stig, and Kampevold Larsen, Janike (eds). 20o8. Norsk littercer kanon. Oslo: Cappelen Damm.

Vederhus, Inger. 1982. Engelbretsdatterstudiar. Master's thesis. University of Bergen.

Vederhus, Inger. 2012. 'Bold of Pen, Bold in Ink' in The History of Nordic Women's Literature. 1993-98. Copenhagen and Gothenburg: Kvinnfo \& Kvinnsam. Online at: http:// nordicwomensliterature.net/article/bold-pen-bold-ink (consulted 28.02.2014). 


\title{
Writing for Patronage or Patronage for Writing? Two Case Studies in Seventeenth-Century and Post-Restoration Women's Poetry in Britain
}

\author{
Carme Font Paz
}

The seventeenth century provided a fertile ground in Britain for anyone who wished to express themselves in writing. London became the locus of an unprecedented printing revolution that carried on until the eighteenth century, when revolutionary writing subsided, but the printing infrastructure in place allowed for greater specialization and diffusion. Separated by almost one hundred years, the two women featured in this chapter seem to have approached patronage as a last-resort solution to attain financial and artistic independence. While Lanyer tried her hand at the court with an air of nostalgia when her businesses failed, Yerbury refused publication since her 'day-job' provided her with an independent source of income that made writing for money and the general public uncalled for. This chapter delves into the rhetorical strategies of both Lanyer's and Yerbury's literary output that were either geared to convince patrons through a religious trope of Christ's love or avoided the spotlight when financial backup was already secured. Both poets separated their means of living from their writing practice, thus revealing that patronage and the market were unstable instruments for the exposure and practice of quality writing.

Forty years ago, J.W. Saunders in The Profession of English Letters noted the importance of the printed-book market for creative writing in early seventeenthcentury Britain, while taking into consideration several factors that posed a challenge to its development. For example, the tradition of manuscript culture in court and coterie writers (which tended to avoid printed dissemination), the Puritan opposition to secular literary forms, the unpredictability of censorship 
mechanisms, and the difficulty in locating an audience. ${ }^{1}$ The seventeenth century provided a fertile ground for everyone who wanted to express themselves in writing. London became the locus of an unprecedented printing revolution that carried on until the eighteenth century, when revolutionary writing subsided, but the printing infrastructure in place allowed for greater specialization and diffusion of writing. ${ }^{2}$ According to Margaret Ezell, a print marketplace did not replace manuscript production as both private circulation and print distribution relied on a close relationship between the text and its social context. A relationship which could imply subtle forms of patronage and professionalization, as, for example, Dustin Griffin has suggested. ${ }^{3}$

Salve Deus RexJudceorum (Long Live the King of the Jews, 1611), the only known work by Aemilia Lanyer, provides a fine example of an early seventeenthcentury poem that straddles the transition between court patronage and the professionalization of print culture. After ample experience in privileged circles as an escort to Lord Hunsdon, Lanyer was forced to leave the court and support herself and her family when she married below her expectations. There is no evidence that Lanyer sought publication to earn a living outside the culture of gift-exchange in court circles, even though she might have contributed in William Shakespeare's circle of associates. If the latter points were indeed the case, Lanyer would have been a professional ghost writer who - when she was forced to leave the court - sought to appeal to a network of female patrons of the arts to reinstate her social standing. Paradoxically enough, when Lanyer went public by printing under her name she gained exposure as an author, but she was further alienated from her alleged patrons, since patronage was still largely associated with manuscript writing and private circulation.

The invisibility of the second case study in this chapter, Ann Yerbury ( $f$ l. 1730s), an unknown poet with notable literary skills, informs us that for early middle-class cosmopolitan women who ran their own businesses, poetry was not to be mingled with printing or going public, as the earnings of their professional non-literary labour gave them the artistic freedom they longed for. Publishing could have meant, for some of these invisible women poets who shunned the 'rise of the novel' in the eighteenth century, a form of annoying patronage in servitude to the market. Separated by almost one hundred years, the two women featured in this chapter seem to have approached patronage as a last-resort solution to attain financial and artistic independence. While

1 J.W. Saunders, The Profession of English Letters, London 2007 [1964], 69.

2 Jason Peacey, Print and Public Politics in the English Revolution, Cambridge 2013.

3 Margaret Ezell, Social Authorship and the Advent of Print, Baltimore 1999, 3; Dustin Griffin, Literary Patronage in England 1650-180o, Cambridge 1996, 5-7. 
Lanyer tried her hand at the court with an air of nostalgia when her businesses failed, Yerbury refused publication since her 'day-job' provided her with an independent source of income that made writing for money or for the general public undesirable or uncalled for. This chapter delves into the rhetorical strategies of both Lanyer's and Yerbury's literary output that were either geared to convince patrons or avoided the spotlight when financial backup was already secured. Both poets separated their means of living from their writing practice, and they were aware of the fact that commercial printing and patronage might curtail their artistic freedom and expose them to a publicity that they sought for only when in need (in the case of Lanyer). This fact alienates literature from the market, but reveals an early and unprecedented awareness that literary skills can be powerful goods in the marketplace of print or in the vestiges of the court elite. By the same token, it reveals that patronage and the market were not regarded as essential instruments for the exposure and practice of quality writing.

\section{Aemilia Lanyer: In Search of Lady Patronage}

Aemilia Lanyer, née Bassano, published her only known collection of poetry, Salve Deus Rex Judaeorum in 1611 at the age of 42, following the Stationer's Register of 2 October 1610. The printer, Valentine Simmes, enjoyed a reputation as one of the best printers in London at that time and had produced several fine quartos of Shakespeare's plays in the early 16oos. Even though A.W. Pollard and G.R. Redgrave list four and then eight copies of Salve Deus, Susanne Woods accounts for nine copies. ${ }^{4}$ These are not identical issues of the first edition even though the printer remains the same. One copy held at the Victoria and Albert Museum in London - and originally meant as a gift to Prince Henry, King James I's oldest son - lacks the dedicatory verses to Lady Arabella Stuart (Prince Henry's cousin), Susan of Kent, the Countess of Pembroke, and Katherine of Suffolk, but includes the Prince's coat of arms on the cover page.

These textual details reveal an awareness of Lanyer's target audience for her writing as well as a deliberate act of self-promotion to win the patronage and the implicit financial support of court circles. The 114 pages of verse in sestet, sonnet, and narrative form, divided into four chapters or collections, have

4 A Short-Title Catalogue of Books Printed in England, Scotland and Ireland and of English Books Printed Abroad $1475^{-1640,}$, eds A.W. Pollard and G.R. Redgrave, 2nd ed. revised and enlarged by W.A. Jackson and F.S. Ferguson, completed by Katharine F. Pantzer, 3 vol. London 1976-1991; Susanne Woods, The Poems of Aemilia Lanyer, Oxford 1993, xlvii. 


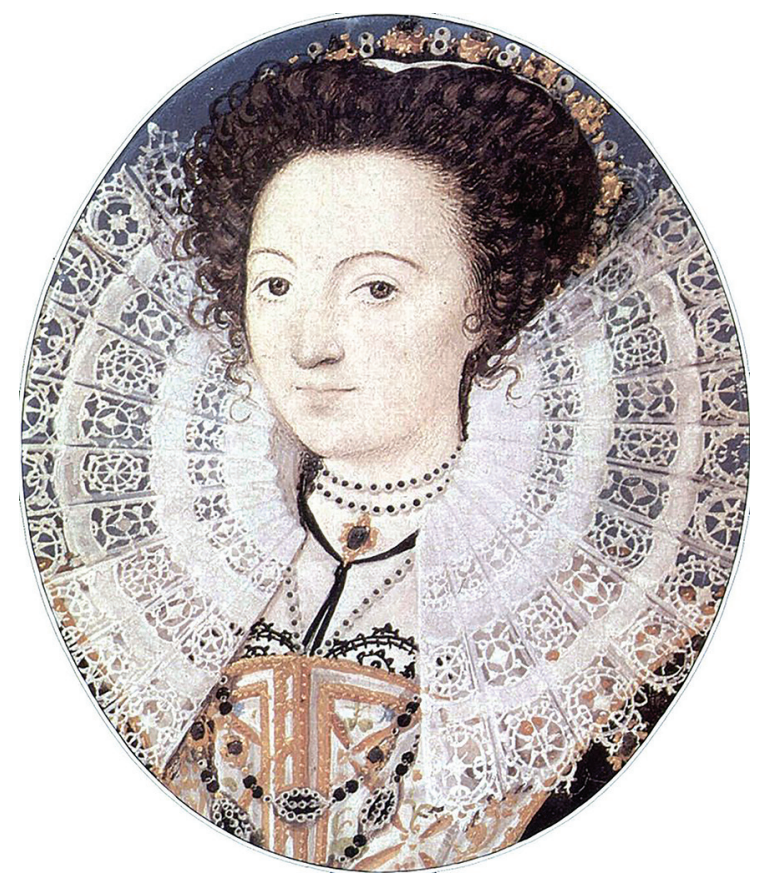

FIGURE 5.1 Portrait of Amelia Bassano Lanier by Nicholas Hilliard (1547-1619). SOURCE: WIKIMEDIA COMMONS, THE YORCK PROJECT (PUBLIC DOMAIN)

been studied mainly for their feministic slant, their religious tones and autobiographical source material. An early interest in Lanyer's life was triggered by British historian A.L. Rowse, who brought up the hypothesis that Shakespeare's Dark Lady was Aemilia Lanyer. ${ }^{5}$ Based on circumstantial evidence, Rowse's claims have not been generally accepted by literature scholars, even though some of the information he provided, particularly his quoted source from astrologer Simon Forman, pointed at significant details about Lanyer's life. She was born in 1569 into a family of musicians of Italian descent, the Bassanos, who earlier emigrated from Venice to London and worked for the Tudor court. Her father, Baptista Bassano, died when Aemilia was a child, and as a teenager she was sent to stay with Susan Bertie, dowager countess of Kent, as a waiting gentlewoman. Lanyer considered Bertie "the Mistress of my youth", ${ }^{6}$ and it was there where the young Aemilia received an education close to a humanist curriculum for women (see figure 5.1.).

5 A.L. Rowse, Shakespeare the Man, London 1973.

6 Aemilia Lanyer, Salve Deus Rex Ivdaeorum, London 1611, 18. 
She also caught the attention of Henry Carey, Lord Hunsdon, Lord Chamberlain of Elizabeth I. He founded Lord Chamberlain's Men theatre company in 1594, for whom Shakespeare wrote and performed his most successful plays. Despite their 40-years age difference, Hunsdon and Lanyer were probably lovers for a decade until 1592, when Aemilia was pregnant with her only son (whom she named Henry) and was made to marry her cousin Alphonso Lanyer, who had been related to the court musical scene. The marriage proved unhappy because of financial constraints, and Aemilia's situation deteriorated further upon her husband's death in 1613. Her dowry was squandered, and she was removed from any contact with the Jacobean court. Her efforts to run her own school or earn some money from a straw-weighing business from Alphonso were likewise unsuccessful. When, in 1597, Aemilia consulted Forman about her horoscope, her main concern was financial, to the extent that she considered "becoming a ladie again" in reference to entertaining gentlemen in exchange for money.

Aemilia appears to us as a woman with a strong personality, well-read, and knowledgeable about the ways of the world. She was most likely of dark complexion due to her Mediterranean and possibly Jewish-Sephardic ancestry (even though her mother, Margaret Johnson, was an Englishwoman). Her exotic physical appearance, her connection with Hunsdon, Alphonso's acquaintance with the Earl of Southampton, and a series of textual concordances in Shakespeare's Italian plays with Aemilia Bassano, are the main elements invoked to argue a connection between Lanyer and Shakespeare that goes beyond sharing the same circle of patrons.

Barbara Lewalski noted that regardless of any possible identification of Lanyer with the "Dark Lady" of Shakespeare's sonnets, her poetry warrants serious scholarly attention. ${ }^{7}$ Even though this particular aspect of Lanyer's life has distracted from and in some cases overshadowed the study of her poetry, recent scholarship has leaned towards interpreting Lanyer's extant work as a self-contained feminine universe of religious piety or as a desperate attempt to gain patronage. Since Salve Deus makes an impassioned defense of women as upholders of virtue and love, it easily lends itself to feministic historicised readings within the context of early modern women's writing. ${ }^{8}$ However, as

7 Barbara Lewalski, Writing Women in Jacobean England, Cambridge, MA 1993, 213.

8 Su Fang, "Aemilia Lanyer and the Politics of Praise", ELH, 67/2 (200o), 433-45; Aemilia Lanyer: Gender, Genre and the Canon, ed. Marshall Grossman, Lexington 1998; L. McGrath, “'Let Us Have Our Libertie Againe': Aemilia Lanyer's 17th Century Feminist Voice”, Women's Studies, 20/3-4 (1992), 345; Barbara Lewalski, "Seizing Discourses and Reinventing Genres", in Aemilia Lanyer, ed. Grossman, 49-59; J. Mueller, "The Feminist Poetics of 'Salve Deus Rex Judaeorum' ", in Aemilia Lanyer, ed. Grossman, 99-127; T. DiPasquale, "Woman's Desire for Man in Lanyer's Salve Deus Rex Judaeorum", Journal of English and Germanic Philology, 99/ 
Longfellow and Coles have shown in their analyses of Salve Deus, Lanyer's innovation in matters of style and themes is fully appreciated when considering the wealth of her narrative sources. From the psalms and the Book of Salomon, to contemporaries such as Nicholas Breton or Giles Fletcher, whose poems on Christ's passion remain largely unread today. ${ }^{9}$

These lucid interpretations of Salve Deus, despite their exhaustiveness, tend to undermine its method of imitatio as a cultural and social referent within a circle of learned, powerful and wealthy ladies. As we shall see, Lanyer's Passion is textually grounded on theological interpretation and typology, in tune with the Protestant allegiance of their addressees, but its tone is neither meditative nor reflective. As Susan Wiseman remarks, "the poem repeatedly provokes the patron to evaluate her response to Christ's Passion as evoked by the poem". 10 The Passion is used exemplarily for its visual and moral impact, and its lack of theological resolution is consistent with its performative nature. Given the scarcity of representations of the Passion in late English Renaissance, Lanyer might have been influenced by Vittoria Colonna and her Pianto sopra la Passione di Cristo (Weeping Over the Passion of Christ, 1557$)^{11}$ in her concern with Mary's sorrow and emotional turmoil, while Veronica Franco's Rime ${ }^{12}$ might have been a likely source for Lanyer. They were both cortigianas onestas, and Lanyer's "Description of Cooke-ham" as well as Franco's "Capitolo 25" (1575), serve both writers as an imaginative space to claim a higher moral and intellectual standard for women - as Christine de Pizan had previously done in Le Livre de la Cite des Dames (The Book of the City of Women, 1405), which Lanyer most probably read. Thus, Lanyer presents her own rewriting of Elizabethan verse, which is also informed by earlier Italian adaptations of the Petrarchan tradition by women writers. The representation of Lanyer's Passion appears to us as a reenactment of her own exegesis of Christ's love and suffering that owes much to a synthesis of Elizabethan Petrarchism and Italian petrarchismo femminile. The dynamic, dialogic, almost prosopopeic narrative invites the reader-patron to partake in a sacrificial ritual of spiritual love in which Christ's sacrifice is equated with the generous act of giving oneself to patronage.

3 (2000), 356-78; E. Hodgson, "Prophecy and Gendered Mourning in Lanyer's 'Salve Deus Rex Judaeorum' ", Studies in English Literature, 1500-1900, 43/1 (2003), 101-16.

$9 \quad$ See K. Coles, Religion, Reform, and Women's Writing, Cambridge 2008; E. Longfellow, Women and Religious Writing in Early Modern England, Cambridge 2004.

10 Susan Wiseman, "Exemplarity, Women and Political Rhetoric", in Rhetoric, Women and Politics in Early Modern England, eds. J. Richards and A. Thorne, New York 2007, 140.

11 Vittoria Colonna, Pianto della Marchesa di Pescara sopra la passione di Christo. Oratione della medesima sopra l'Ave Maria, Bologna 1557.

12 Veronica Franco, Rime, a cura di Stefano Bianchi, Milan 1995. 
Lanyer's adaptation of Petrarchism is also to be appreciated in Shakespeare's sonnets, as John Hudson has argued convincingly in the biographical and textual traces of Lanyer in Shakespeare's plays. ${ }^{13}$

David Lasocki and Roger Prior have reconstructed and contextualised every available piece of information about several generations of the Bassano family as musicians and instrument makers up to Aemilia's life in London. Most of their book The Bassanos $(1995)^{14}$ has historical interest for musicologists, but the chapter entitled "Was Aemilia the Dark Lady?" is obviously appealing to the literary historian. The authors are careful not to support Rowse's bold claims about the identity of the Dark Lady, but they reach similar conclusions and draw much of their evidence from Simon Forman as well. Even though Lanyer's scholars are reluctant to acknowledge that Shakespeare and Aemilia knew one another, Lasocki and Prior state that "there can be little doubt that Shakespeare knew Aemilia". ${ }^{15}$ They invoke the etymological coincidences in Shakespeare's Italian plays: Emillius and Bassanius in Titus Andronicus, Aemilia in Othello and Bassanio in The Merchant of Venice. Above all, they underline the fact that they both belonged to the same small group of professional court entertainers. This apparent coincidence might not have been such, since Aemilia had a peripheral relationship with the Jacobean court after her separation from Henry Hunsdon and her marriage to Alphonso in 1592.

The publication of the Salve Deus collection as late as 1611 is in itself a token of Aemilia's lack of favour and activity in the court. Erica Longfellow notes that "although other women had added dedications to their poems, none had so clearly inscribed the search for patronage into their work". ${ }^{16}$ Isabella Whitney, who printed her poems in $1567^{17}$ and addressed ladies in generic terms or metaphorically as "flowers of philosophy", did not produce a catalogue of possible patronesses, and neither did Ann Lock in her sonnets (1560) or Mary Sidney Herbert in her translation of the Psalms, ${ }^{18}$ which circulated in manuscript form in the 159 os and Aemilia might have read. A more obscure figure, Jane

13 Colleen Shea, Literary Authority as Cultural Criticism in Aemilia Lanyer, London 2002, 386-407; W.M. Roberts, “Gnosis in Aemilia Lanyer's 'Salve Deus Rex Judaeorum' ", Rocky Mountain Review of Language and Literature, 59/2 (2005).

14 David Lasocki and Roger Prior, The Bassanos: Venetian Musicians and Instrument Makers in England, 1531-1665, Aldershot 1995.

15 Ibid., 117.

16 Longfellow, Women, 59.

17 For a modern, albeit incomplete edition of Whitney's poetry, see Renaissance Women Poets, Isabella Whitney, Mary Sidney and Aemilia Lanyer, ed. Danielle Clarke, London 2001. 
Seager, ${ }^{19}$ was very explicit and creative in her appeal for patronage in Elizabeth I's court when in 1587 she translated the prophecies of the ten Sibyls from the Latin of Filippo Barbieri's Sibyllarym de Christo Vaticina and encased them in a binding of velvet. ${ }^{20}$

The complete collection of Salve Deus Rex Judaeorum is addressed to nine noblewomen, some of whom she did not know personally: Queen Anne, Princess Elizabeth, Lady Arabella Stuart and the Countesses of Kent, Pembroke, Bedford, Cumberland, Suffolk, and Dorset, plus a general address to "all virtuous Ladies in general". The Countess of Pembroke and the Countess of Bedford maintained circles of poets and Aemilia's main patron, Margaret Clifford, Countess of Cumberland, was one of the dedicatees of Spenser's Fowre Hymnes (1596), another source for Lanyer. Her address to nine ladies, a number that coincides with the nine Muses of Mount Helicon, is unprecedented and serves a narrative, pragmatic and performative purpose.

It is unclear whether Aemilia ever knew Shakespeare personally, but it is perfectly possible that they knew of each other. They had common acquaintances and both strove to survive in the competitive arena of courtly patronage - although Shakespeare was far more successful than Aemilia. More than a hypothetical personal connection, they shared similar challenges by dint of their social standing and possibly their personal ambitions. Both published their respective poetry collections within two years (1609 and 1611) and both were experienced in the glories and miseries of human fortune. Any reverberations between Lanyer's and Shakespeare's work becomes meaningful when viewed as pieces of a shared artistic and generational tapestry, interacting in multifold variations of the same cultural capital that feeds on the practice of eclectic borrowing, imitation and adaptation.

One of the most striking echoes of Shakespeare in Salve Deus is the commonplace metaphor of the world as a stage, which according to Lanyer's formulation is closer to Antonio's verses in The Merchant of Venice: "I hold the world but as the world, Gratiano/A stage where every man must play a part, And mine a sad one"21 than to the monologue of the seven stages of man in $A s$ You Like It. ${ }^{22}$ Lanyer writes that "For well you knowe, this world is but a Stage/ Where all doe play their parts, and must be gone"23 for the daughter of her

\footnotetext{
19 Jane Seager, "The Divine Prophesies of the Ten Sibills" ed. Jessica Malay, English Literary Renaissance, 36/2 (2006), 189-93.

20 For an extensive discussion of Elizabethan manuscript poetry by women, see Early Modern Women's Manuscript Poetry, eds Jill Millman and Gillian Wright, Manchester 2005.

21 William Shakespeare, The Merchant of Venice, ed. J.L. Halio, Oxford 2008, Act 1:1.

22 William Shakespeare As You Like It, ed. A. Brissenden, Oxford 2008, Act 2:7.

23 Lanyer, Salve Deus, 46.
} 
main patron, Anne Clifford, Countess of Dorset. Since the beginning of her dedication to her, Lanyer calls for preparing (with "Lampes with oyle") "to enter with the Bridegroome [Jesus Christ] to the feast, where he that is the greatest may be least". ${ }^{24}$ Lanyer embarks on a lengthy explanation of why the last will be the first, borrowing from the parable of the labourers in the vineyard from Matthew 20:1. She dismisses external displays of virtue ("Greatnesse is no sure frame to build upon") because only virtue based on love can be immortal. If a powerful individual does not devote himself to good deeds, then this is the mark that he or she does not stem from a virtuous linage: "If he that much enjoyes, doth little good, we may suppose he comes not of that blood". ${ }^{25}$ Aemilia is inviting the countess of Dorset to take up her stand in the world stage by performing good deeds because this is the unmistakable sign of virtue.

This standpoint is ritualised in two acts that Aemilia invokes throughout her poem: receiving Jesus Christ in steadfastness at the Feast table and developing a generous attitude towards others, in particular women such as Aemilia who are "humble" and vividly aware of the abuses of men. She in turn can only act as a facilitator of God's love in their lives:

Therefore to you (good Madame) I present

His lovely love, more worth than purest gold,

Who for your sake his pretious blood hath spent,

His death and passion here you may behold. (46)

Lanyer's equation of patronage with divine love - inscribed in Christ's sacrifice - instills dynamism in Salve Deus. Women's love of Christ is of superior quality to that of men and, as a result, female patronage is too. After the dedication to the Countess of Dorset, Lanyer describes in the chapter "To a Vertuous Reader" that the men who criticise women are the same kinds of men who "dishonoured Christ his Apostles and prophets, putting them to shamefull deaths". ${ }^{26}$ John Rogers contends that "Lanyer's representation of the Passion enables her retrospectively to assume for herself the right to have written this poem" identified as "holy work", ${ }^{27}$ but Aemilia's authority as a writer does not seem to require any strategy of endorsement since she does not hide a personal relation (or lack thereof) with some of her would-be

\footnotetext{
24 Ibid., 41.

25 Ibid., 43.

26 Ibid., 49.

27 John Rogers, “The Passion of a Female Literary Tradition: Aemilia Lanyer's 'Salve Deus Rex Judaeorum' ", Huntington Library Quarterly, 63/4 (2000), 442.
} 
patronesses, even if one is the former queen, Elizabeth I: "And this great Ladie whom I love and honour/And from my very tender yeers have knowne". 28 Aemilia seeks a reaction in her readers-patronesses: to accept the love of Christ in their lives.

The evangelical slant of Salve Deus has been overshadowed in many analyses of the representation of Aemilia's passion of Christ for its visual spectacle: mainly, the eroticism of Christ's body, close to a Gongorean and Baroque image of the contorted and fatally wounded Christ. Lanyer's exhortation to her patrons to gaze upon and desire the body of Christ as a symbol of grace is one of the most frequently discussed aspects of her poem, even though the display of this motif in English devotional literature has not been sufficiently studied. Debora Shuger locates this tradition of finding Christ's love in his Passion in the early reformers and even Calvin himself, ${ }^{29}$ and as a result later English Calvinist accounts of the Passion resort to a Catholic tradition of the inner suffering of Christ since this highlights the inner struggle of an 'elect soul'. A vivid representation of Christ's Passion allows Lanyer to reconcile her mixed devotional heritage as the daughter of an Italian Catholic family who had become Protestants in England. The gentle and visually beautiful representation of Mary's lamentation while holding the dead body of Christ is an unusual image in English Elizabethan poetry, which Lanyer may have read in Vittoria Colonna. Particularly, on the tone of motherly suffering - itself an appropriation of Jacopo Sannazaro's Lamentatio de Morte Christi (Lamentation of Christ's Death, 1526).

Whether Lanyer's notion of the Passion of Christ is inspired by her family origins or not is beside the point. It may help understand her intimate knowledge with this imagery, but not why she is using it as a model, or even as a ploy, for patronage. The answer to this has again more to do with Lanyer's authorial and narrative intentions than with a conscious choice of theology. Integrating spiritual love in one's life can be achieved more effectively when the 'exempla' illustrates the constructive effects of love. Suffering cannot "fold up all Beauties in your breast" (129) or be the "Husband of Thy Soule" because it does not foster generosity of spirit. Again, Lanyer's adaptation of typological references of the Psalms is contingent upon a performative action that she prioritises. It is a form of 'personation' that is close to a prosopopeia. Adamson, Alexander and Ettenhuber define it as a mask, which - however close to a real person - is a performance whose rhetoric has persuasive value in the context

28 Lanyer, Salve Deus, 8.

29 See Debora Shuger, The Renaissance Bible: Scholarship, Sacrifice, and Subjectivity, Berkeley 1994 . 
of Renaissance poetry. ${ }^{30}$ Shakespeare's Sonnets are more interactive than persuasive, and look forward to provoking thought in a reader-witness instead of eliciting a proactive response from a reader-patron.

The sorority of Salve Deus is not grounded in a meritocracy of the spirit. The exalted quality of recognising and expressing the love of the soul is predicated first on the grounds of being a woman of social stature. And then, as we have seen, on the good deeds that such recognition of Christ's love inspires:

This Grace great Lady, doth possesse thy Soule, And makes thee pleasing in thy Makers sight, This Grace doth all imperfect Thoughts controle, Directing thee to serve thy God aright. (62)

Lanyer's politics of praising is taken to an extreme for the sake of inviting patronage. At the same time, it gives her a cue to justify her inspiration by a Muse. The Grace of these great ladies, and especially Lanyer's main patroness the Countess of Cumberland, inspires her to trigger their latent love into action. Aemilia is thus invested with the power of divine inspiration to become a purveyor of the gift of love to her reader-patron ladies. The narrative effect is irresistible, since Lanyer authorises her poetic speech and her entreaty to patronage by dint of her prophetic powers:

These high deserts invites my lowely Muse To write of Him, and pardon crave of thee, For Time so spent, I need make no excuse, Knowing it doth with thy faire Minde agree So well, as thou no Labour will refuse. (62)

The recognition of Christ's love is the prerogative of women and, particularly but not exclusively, the responsibility of those from high social standing. Lanyer considers that a virtuous life inspired by the love of Christ is the mark of true nobility, but she is also aware that this is not a guarantee of fairness:

What difference was there when the world began?

Was it not Virtue that distinguished all?

All sprang but from one woman and one man

Then how doth Gentry come to rise and fall? (36)

30 Renaissance Figures of Speech, eds Sylvia Adamson, G. Alexander and K. Ettenhuber, Cambridge 2011, 111. 
This series of rhetorical questions fall into the cliché of being 'equal in the sight of God' They also attempt to comfort Anne Clifford, who was entangled in a legal dispute to inherit her father's estate (42). Line 36 reveals a moment of crisis in which Aemilia interrogates the mystery of divine justice: is salvation, including social salvation, a matter of faith alone, or of virtuous deeds? As we have seen, Lanyer's structure and content of her Passion suggests the second option in consonance with her likely Christian leanings, but she is also aware of the challenges that social degeneration poses to even the most virtuous of individuals. For Lanyer, spiritual love can be experienced when it is gladly accepted as a redemption of Christ's suffering or as compensation for social alienation. Thus patronage becomes metaphorically an act of higher love that perpetuates class differences as much as it effaces them.

\section{Ann Yerbury: Becoming an Invisible Author}

Approaching the considerable poetic production of Ann Yerbury, a perfectly unknown poet in her lifetime as well as in ours, challenges the notion that in order to be termed a professional writer one has to obtain some sort of benefit from it. And yet, gain cannot be completely dissociated from Ann's writing practice, since it enabled it on a regular basis. To the excitement of holding, reading and making sense of a collection of poetry that has not been transcribed or edited before, we may add the growing realisation that Yerbury's case may not be a one-off trove. Decades-long established critical assumptions about the rise and maturity of the novel as an eighteenth-century genre that allowed the professionalisation of women writers coexist with an alternative dormant reality: the manuscript output that we find in archives and libraries by women who wrote for self-expression and the advancement of their learning with an apparent disregard for seeking money or recognition through their writing. Judging whether Yerbury's poetry ranks among the best poetry of her day is beyond the scope of this chapter, but her case brings home a series of questions that invite us to reconsider the connections between life-writing, women's canonical production and the dichotomy between writing for profit or attaining profit for writing.

There is virtually no information about Ann Yerbury's life. We know she was the wife of William Yerbury, who belonged to a wealthy family of clothiers in the Bristol region of England. A leather-bound notebook written by Ann's mother and found among her papers informs us that Ann was married to William on 24 June 1735. They moved to London soon afterwards and she gave 
birth to three children: John (1736), Ann (1737), and Mary (1738). Her husband died in 1741. The Bristol Record Office records a Yerbury family of clothiers in a record of Assignment of a lease from February 1693, in which a John Yerbury, "late of Beckington, co.Somerset" is mentioned. ${ }^{31}$ There is also mention of a letter from Ann Yerbury to Mr and Mrs John Kiddell from Bradford - which became an important textile centre in the nineteenth century - dated on 11 October 1748. She may also be the Ann Yerbury, widow of Bradford, Wiltshire, whose will is dated on 30 May 1799.

Ann Yerbury's mother details births, deaths and marriages from several members of her immediate and extended family. However, she does not record the birthdate of her two children that appear mentioned in the notebook. She only refers to a brother of Ann, Charles, who "died ye 21 of Oc:br of 1740 in $\mathrm{y}^{\mathrm{e}} 34$ years of his age", without giving further details about the circumstances of his passing. This date indicates that Ann may have been born in the first decade of 1700. In one of Ann's own poems, she reveals that her birthday is on 12 February. Curiously enough, Ann's mother records in her diary that "my mother Smyth died ye 12 day of Feb ${ }^{\text {ry }} 1717$ ". The coincidence in the day of Ann Yerbury's birth and her grandmother's death may explain why Ann's mother did not want to mention her birth date, or it might be argued that there was no need to write those dates down on paper because she remembered perfectly well the birthdates of her two children.

Other than the factual information surrounding the scarce details about Ann Yerbury's biography, the notebook is significant as an artifact of women's writing. It was not uncommon for women to keep a record of family mementoes and genealogy. However, this notebook in particular denotes a willingness to be objective by providing the raw facts while, at the same time, it is emotionally selective in its criteria for inclusion. Members of the family are missing, and there are also omissions in the categorisation of events. If Ann's mother had aimed at being thorough in her record, she would have mentioned, for instance, the date of Charles' marriage, since she includes the date for the death of one of his children. Her memory is selective even when she attempts to be objective, or this objectivity is only in appearance. Ann Yerbury's poems and prose also rely on memory and choice in the construction of her literary persona and in her life-writing, and in ways which would have startled any commercial printer.

31 Bristol Record Office, Records of the Anglican Parish of St Mary, Assignment of a lease, 2o February 1693. Ref no P/Xch/D/2o(b)i-ii. Retrieved online at the Bristol Record Office $<$ http://archives.bristol.gov.uk> 
The Ann Yerbury Papers collection is held at the William Andrews Clark Memorial Library in Los Angeles. ${ }^{32}$ The library catalogue describes it as "devotional poetry before 1800 " and as "Poems and prose written by Ann Yerbury between 1729 and 1753 on various themes including illness, religion, friendship, reflections, and death". The collection is arranged thematically into 3 groups. Most items are poems ( 48 pieces) from $173^{2-53}$, but there are also three earlier pieces of prose (1730) that Yerbury defines as "themes": the family papers, and a modern newspaper article and letter dating from $195^{\circ}$ and 1956, respectively. The news clip features a short report about Belcome Court, in Whiltshire, Bristol area, where the Yerbury family lived - according to the report - from the fifteenth century to the early twentieth century. The Yerburys were keen on architecture, and their house and gardens underwent several reforms from notable architects in the late eighteenth century. The newspaper clip is attached to a handwritten note from Hugh Rogert \& Nicholl, surveyors, probably signed by Nicholl, who sends it to a Mr Bangham because "your wife is connected to this family". Another paratextual piece of ephemera is kept in a separate folder-box of the collection. It is a frost-fair keepsake with a woodcut illustration of a pastoral landscape and the caption "Ann Yerbury. Printed on the River of Thames when Frozen over, January 30, 1739-40". These keepsakes had been very popular since the seventeenth century in particularly cold winters when the River Thames froze. Frost Fairs and stalls were set up and letterpress keepsakes were made on the spot with the name of the buyer.

Ann Yerbury might have visited the Thames in the winter of 1739-40 and had one of these keepsakes printed for her with her name on it, even though her writings do not mention any trip to the river. This might have been the only time Yerbury saw her name on printed matter, albeit never her work.

The 'family' papers of the collection give insight into the everyday management of a household. They are penned with the aim of keeping a record of family affairs, especially if any incident has occurred in the house. Yerbury also writes a "hymn for the late public safety in ye time of the Rebellion 1745" where she expresses her concerns about the Jacobite Rebellion in 1745 and how it altered public order. Most of her writings are devoted to reflections and meditations on illness and death. Through her soliloquy on 'morning bliss' during her walks and her meditations on death, Yerbury reveals not only her frail state of health during 1749-1753, but how her illness is strengthening her resolution to live for the good of her family and God. In 1750, after one of the coldest winters

32 MS.1994.002. The author of this chapter wishes to thank the William Andrews Clark Memorial Library for permission to quote from The Yerbury Papers collection. 
ever registered in London, Yerbury begins a cycle of recoveries and relapses that she attributes to the 'hand' of God. She is torn between her determination to live and her respect for divine will.

It would be an oversimplification to consider Yerbury's manuscript an exercise in domestic 'occasional verse'. It happened indeed on regular occasion but did not follow the discipline of a diary. Most of her poems were triggered by an event, which Yerbury considered important in the flux of personal or communal history. This is one of the specific traits that make Yerbury's collection original and professional in its viewpoint. Even though we can trace a thread in her choice of themes, Yerbury displayed a range of circumstances that led to her main concern: our place on earth in the face of death. She felt herself to be a subject of history, a "soul" who needed to make sense of how her personal story related and interacted with those circumstances. This mimetic quality and the capacity to grant historical transcendence and momentum to personal affairs - while interpreting communal events as being part of a fragmented but cohesive narrative - is Yerbury's characteristic poetic seal.

Often these concerns are articulated in a religious key from the viewpoint of a woman who is pious as well as versed in the Bible. Nevertheless, she displays a more limited textual knowledge of the scriptures than her seventeenth- or sixteenth-century peers since she rarely paraphrases episodes or lines from the Bible. Yerbury's use of pious language owes more to an ad hoc stylistic preference than to a willingness to draw an exegesis. She demonstrates strong religious convictions in God's love as a unifying energy that inspires at difficult moments and helps to understand ethical concerns. She is not preaching or prophesying, even though she can give advice to others or warn them. Jesus and Jehovah (instead of 'Lord', in keeping with the denomination of the King's James Bible) are a moral force to Yerbury in her survey of her inner and outer world.

One of the earliest items in the collection is a bunch of prose papers composed in 1730. The first of these is entitled Some Reflections on Death, and it starts with a set of questions that marks the discursive tone and the inquisitiveness of her approach to mortality:

How common is it for the generality of mankind to be afraid of Death? If possible wo'd they not fly him as from their most dreadful foe? Oh, how they tremble at his approach? What terrors possess their soul at his approach! And what would they not give, was it possible to bribe off ye fatal hour? ${ }^{33}$ 
Yerbury goes on describing that only people attached to pleasures would find death unbearable. She argues that, far from being terrifying, death is a place of solace and reunion with the love of God. However, her argument gains complexity when she reviews the reasons why someone who leads a 'bright' life should be afraid of death. Is it because they do not want to depart from their families? There are traces of a Sapphic poetic component in her train of thought, a welcoming of death not as a redemptive force but as the pleasant dwelling of the soul. She articulates her desire for mortality:

In the most agreeable scenes of my Life, I can think on Death at a future state with joy. Rottenness at the grave are no mortifying thoughts to me. What though my body is laid in the dust, my soul shall mount up to the glorious mansions already prepared. My soul can never decay if nourished with spiritual food. ${ }^{34}$

There is a distinctive mortal quality in Yerbury's writing, a preoccupation with any event or emotion that confronts her with the fragility of existence. The prospect of death threatens her physical being, but it empowers her true spiritual one. Death is the motive underpinning her autobiography: writing is a proof of being alive and of participating in the flow of history, which is ruthless but mitigated by God's hand who cares for one's soul. Thus, life-writing guarantees a place not only in history, but in eternity. Her physical life belongs to history, her spiritual one is timeless.

Perfect love, uninterrupted peace, blissful harmony, friendship disinterested and without end. Oh!, with what transports of joy would I embrace that kind, that welcome messenger, who would release me from this stage of mortality, this fleeting theatre. ${ }^{35}$

Her poetry enacts a struggle between facts and their possible transcendent meaning. There is no willingness to proselytise when Yerbury refers to salvation; there is instead an impulse to know, to rationalise and to communicate her sense of existence. By welcoming death and fighting it on occasions, Yerbury derives her notion of personal story (and tragedy) from her construct that the individual is a co-participant in her destiny.

The advice that she gives To a Professed Libertine (1730) follows a similar pattern: a description of a state of death "within the vaulted earth" in which the 
libertine's pleasures will "thy memory blot" and worms "will be the constant companions in the shades with thee". But even if one misspends his life, "your conscious soul, alas! Can never die". The metaphorical images are reminiscent of the graveyard poetry as in Robert Blair's The Grave (1743), but the genre flourished some years after Yerbury composed these poems and she does not entertain gothic scenes of death, as is the case with Blair or Edward Young with Night Thoughts (1742). Meditations on death, epitaphs and reflections upon one's own life at the prospect of death (whether real or imaginative) were not uncommon in much of the poetry produced by women in the early decades of the eighteenth century. Yerbury's versification on this subject is in line with what her contemporary women writers had published or circulated around that time. Mary Chandler, who ran a milliner shop in Bath and published a much-read poem entitled A Description of Bath, wrote her "Own Epitaph" in 1736 in which she takes stock of the way she had lived, conveying a sense of moral self-assessment with no dramatic artifice, lamentation, or attempt at philosophical disquisition. However, the depth of her message touches modern readers:

She never could forgive, for she never had resented;

As she never had deny'd, so she never repented.

She lov'd the whole Species, but some had distinguish'd;

But Time and much Thought had all Passion extinguish'd. ${ }^{36}$

Chandler writes in heroic couplets, as Yerbury does, and displays a similar pattern of acceptance and resolution that is also predicated in her poetry. In this poem, Chandler weaves contrasting images that reinforce her poetic statement: that she has left an imprint as a soul ("Believing she lost not her Soul with her Breath"). The outcome of finding this balance between accepting your modest public place in history and building your own story based on strong ethical grounds is a poetry that reveals a taste for reporting everyday events in a sincere voice. It is closer in the choice of tone and topic to the working-class, kitchen-maid poetry of Mary Leapor, for instance, than the bluestocking rhetoric of Lady Mary Wortley Montagu when she addresses a similar subject matter in Answer to a Lady Who Advised Retirement:

In crowded courts I find myself alone, And pay my worship to a nobler throne.

$36 \quad$ Mary Chandler, "On my own epitaph" (1730), in Eighteenth Century Women Poets, ed. Roger Lonsdale, Oxford 1990, $15^{2}$. 
Long since the value of this world I know, Pity the madness, and despise the show.

$[\ldots]$

Seldom I mark mankind's detested ways

Not hearing censure, nor affecting Praise

And unconcern'd, my future fate I trust

To that sole Being, merciful and just. ${ }^{37}$

Montagu's self-assessment at the prospect of death is poetically arresting, but less grounded in concrete experience ("value of this world", "mankind detested ways"). Yerbury, as a member of a middle class that relies more on work than salons, on networks of neighbors than women cliques, is both a reflection of her intimate sphere as much as her personality as a poet - but it is not, despite the recurrence of pastoral topoi, an exercise in Augustan imitation and versification.

Sarah Prescott, in her analysis of the coexistence of manuscript and print poetry in this period reminds us that the years from 1690 to 1740 cannot compare to figures of the later eighteenth century in terms of textual production, even though the period is important to understand the subsequent flourishing of women's writing. She mentions three patterns in particular, "the significance of provincial culture, the marketing of virtue as a saleable commodity, and the emergence of the highly public yet respectable woman writer", ${ }^{38}$ all of which resonate with Yerbury's poetry inasmuch as it instils real life into current affairs, and a human touch of transcendence that is heartfelt without relying on emotionality or sensibility. Scholars of eighteenth-century women's poetry have identified its fragmentary and imaginative nature as well as its appropriation of classical poetical models. ${ }^{39}$ These formal idiosyncrasies may have prevented us from appreciating the depth of thinking behind the base material that women used as subjects of poetical creation: life-writing.

37 Lady Mary Wortley Montagu, "In answer to a lady who advised retirement" (1730), in British Women Poets of the Long Eighteenth Century: an Anthology, eds Paula R. Backscheider and Catherine E. Ingrassia, Baltimore 2009, 688.

38 Sarah Prescott, Women, Authorship and Literary Culture, New York 2003, 9. For a monograph on habits of reading and writing in provincial England, see Jan Fergus, Provincial Readers in Eighteenth-century England, Oxford 2007.

39 Paula Backscheider, Eighteenth-century Women Poets and their Poetry: Inventing Agency, Inventing Genre, Baltimore 2005; Producing the Eighteenth-century Book: Writers and Publishers in England 1650-1800, eds Laura Runge and Pat Rogers, Newark 2009; Gillian Wright, Producing Women's Poetry, 1600-1730: Text and Paratext, Manuscript and Print, Cambridge 2013. 
There is a marked individuality in Yerbury's poetry that makes no pretense of imposing into the public sphere; but then, there is no doubt about her selfauthority. Since Yerbury did not write for an audience - although she might have circulated her poems among her circle of friends and relatives - we may assume that she enjoyed greater freedom by not being published. There is no reference in her poems to any wish to be published or any regret for not going public, but yet her poetry and prose are assured. Can we deem as literature those writings that are not geared towards a public audience? Ultimately, what we see in the traces of invisible women such as Yerbury is that their production enjoys an intellectual freedom of speech that may be more restrained or predictable when it is conceived with an audience in mind (even if the texts were published posthumously).

There is in Yerbury, though, a sense that her writing can and should be useful for others to read, not because she is relaying the word of God or speaking on behalf of a political agenda, but because her vision is the result of self-meditation and analysis of the world inside and around her. Yerbury's production spans two crucial decades of rapid changes in the spread of the professionalisation of women's writing. Yerbury would have enjoyed in theory more opportunities to expose her writing to a larger public than her predecessors, had she found a list of subscribers to support her printing enterprise. There is no way of knowing, from her extant materials, whether she attempted any of this or whether she was willing to do so. She was a wife and a working mother in her family business. She did not endure financial hardships, even though she could not afford to quit her 'day job'. She was to all intents and purposes a modern working mother, a member of the educated middle class who derived her sense of worth from her work and community life. ${ }^{40}$ There is not in Yerbury's poetry, however, any vindication of class pride or even any mention to her business. It is an intense personal and meditative poetry that does not borrow the rhetoric of sensibility and rationalises what it means to be alive in the meanders of fate. She does not vindicate women's rights, but she does not assume a stance inferior to men. She aims at being universal through her particular case. In this regard, Yerbury is closer to the popular kitchen-maid poetry of Mary Leapor in her absence of an audience despite her strong vindictive messages of gender, class, and abuse. Leapor, though, was published posthumously by subscription. Invisible poets, such as Yerbury, pose a question mark on the intersections between class and opportunity in their chances to achieve

$40 \quad$ For an overview of middle class women and their productivity, see Women, Work and Wages in England, 1600-1850, eds Penelope Lane, Neil Raven and K.D.M. Snell, Rochester, NY 2004. 
public recognition. Her class or gender did not prevent Yerbury from being published, but she did not belong to or corresponded with networks of bluestockings and learned societies. Her choice of genre and method of inquiry (meditative, philosophical, iconoclast and fragmentary throughout a unifying theme) was not easy to market in the buoyant supply of novels. Yerbury lacked opportunities because she was normalised into the middle-class system and her poetry might have seemed even to her an individual pursuit of no social or intellectual value. She did not hack for the market, and her options as a published writer must have been scant due to intellectual prejudice. Leapor's plight, however, appeals to the curiosity of the more privileged members of the middle class for her depictions of the abusive working conditions of maids. This treatment is not restricted to employers, though, as Leapor denounces parental abuse in her lines:

Then to her Fancy Celia's Woes appear,

The Nymph, whose Tale deserves a pitying Tear;

Whose early Beauties met a swift Decay;

A Rose that faded at the rising Day

While Grief and Shame oppress'd her tender Age,

Pursu'd by Famine and a Father's Rage. ${ }^{41}$

Leapor's choice of the name Celia and the reference to the decay of beauty resonate with an inversion of Pope's short poem To Celia: "Celia, we know, is sixty-five, Yet Celia's face is seventeen; Thus winter in her breast must live, While summer in her face is seen". Yerbury resorts sometimes to pairs of pastoral pen names in her poems (Cassander-Celia, Cleone-Lucinda, Lysander, Cynthia). Even though Leapor's tone is more belligerent than Yerbury's in the 173os, the pathos of accepting one's lot while resolving to live according to one's own vision is prevalent in most women's poetry from the 1730s and 1740s. On the occasion of another significant event in Yerbury's biography, the death of her mother, she takes up the quill to record it and writes Soliloquy to Sudden Death. She returns to her usual subject matter of the mystery of existence:

But in what manner hence she took her flight

What mortal knows? Unseen, she pierced the clay:

Unseen, these lower mansions gaily fled;

She left a track behind, that we might trace

41 Mary Leapor, "The cruel parent" (1730) in Richard Greene, Mary Leapor: A Study in Eighteenth-century Women's Poetry, Oxford 1993, 67. 
Her airy footsteps, thro' the blissful road.

Think oh my soul! This moment only thine,

In this probationary state: the next,

Thy state is fix'd: tremendous thought! ${ }^{42}$

Yerbury's tone is deeper and somber in her later poetry, when her meditations on death become a narrative motif to defend one's own dignity in life. It enunciates her own sense of power and authority in this "probationary state". Yerbury's voice becomes outspoken when she writes an impassionate defense of a 'deceased gentleman' who has been slandered upon death by an anonymous "author of a scurrilous elegy" (1749): "Nor let thy Spleen in Slander still delight:/Do justice to the venerable shade/Do justice to yourself: nor thus degrade". Yerbury's staunch defense of self-dignity is built upon a sense of personal integrity.

Yerbury dedicates much of her poetic production to friends and relatives who have passed away or are seriously ill, employing this same Sapphic undertone of celebratory dying, including her own "impending" death in 1733 that did not happen when she composed a Hymn "to be sung before her funeral sermon". She can't wait to let herself go at the prospect of gaining new knowledge and "seek beyond the skies". God invites her to do so: "Come, fly this dull, this narrow sphere/And regions new survey". Death is also for Yerbury an appealing place where true wisdom, knowledge and love can be realised. She often refers to the narrow-mindedness of earthly life and converses with a God who offers a heaven of personal salvation in which true understanding reigns. It was not uncommon for Yerbury to revise her poems "years later", in some cases even twenty years later, which shows a commitment to writing as her mode of expressing and revising her feelings. She discloses her approach to writing in her Poem on a Sabbath Day:

When in my closet, from the world retired My thoughts, my soul, \&all by heaven inspir'd Shall nobly show the empty joys of life Domestick quarrels, or more publick strife (Which spread their black contagion here below) and upward fly, from whence my comforts flow. The noblest objects, shall employ each thought. With love sublime \& admiration fraught. ${ }^{43}$

42 Yerbury, Soliloquy to Sudden Death, 1747.

43 Yerbury, Poem on a Sabbath Day, $173^{2}$. 
Writing is for Yerbury a mental exercise of observation that is inspired by heaven, but not mediated by it. She is not an instrument or an agent of the divine. Through silence and meditation she reaches an inspired state, which allows her to employ her thinking and creative abilities to make sense of the world around her and inside herself. Her visions are assisted sometimes by classical thinkers - "And now methinks I see the sons of art/Like Aesculapius, acting each his part" - (1733), or her invocation as a muse to Apollo on occasion of Queen Caroline's illness in 1737 - "Fly to thy learned sons with sacred art/some sovereign medicine ere too late impart/Oh Gods, I ask no more than you can give". These create a syncretic effect in her poetry that move her necessarily away from restrictive interpretations of women's poetry as closet versification.

Yerbury's poetry is no different in her mastery of contemporary tropes and stylistic resources from the production of many of her contemporary poetesses. Despite her fragmentary, episodic nature and the scant material traces of her biography, a recurrent theme weaves her collection: the meaning of life and the construction of an ethical self who is inscribed in a community that alienates the individual soul. Even though Yerbury does not write on impulse, there is often an episode that triggers her sense of biography as history. Her working use of Augustan pastoral poetry shows that she participated in a poetic tradition of women's writing and a cultural capital that cultivated life-writing as a method of historical analysis to generate original thinking about oneself and the world. Ann Yerbury's case reveals to us that, despite her extreme invisibility - there is no evidence about the circulation of her poetry or her willingness to go public - women poets wrote with authority about their chosen themes. Yerbury belonged to a middle class that relied on its work and did not endure financial constraints, but she chose not to publish by subscription and make herself known. Several factors might have impinged on her invisibility as a poet, and some of them might have to do with a classed consciousness that going public meant exposing oneself and one's work to criticism.

\section{Marketing Talent}

Publishing was becoming a market, and the woman professional writer who relied on it for her sustenance might have been aware of the constraints of the market that women poets such as Yerbury ignored or chose to reject. When reading original manuscripts, we are reminded that the history of women's writing and production of ideas happened very often on the margins of the market even when women enjoyed unprecedented opportunities to be published. Bigold has recognised the urgency of approaching the period from a 
more holistic point of view, since for the most part, "scholars have been content to assess a writer's engagement and importance based on their productions in print". ${ }^{4}$ The need to recognise that "there were forms of social authorship wider than the print market", 45 which reveals the degree of involvement of women as writers who generate knowledge through life-writing (and writing for life) in the form of poetry, letters or miscellaneous genres of prose and fiction.

Helen Smith explains how dedications existed as "sites of rhetorical play, peritextual structures designed to constrain and direct the reader, and elements of the complex system of patronage that drew together social, political, and religious, as well as literary, life". ${ }^{46}$ She further describes patronage in the seventeenth-century as a "network of associations". ${ }^{47}$ In early modern culture, a successful candidate had to forge emotional links with a prospective patron. Jessica Malay argues that in order to gain patronage through writing, as was the case with Lanyer, "it was essential to carefully construct a text that would strengthen the writer's affinity with the patron either through the creation of a new bond or the building upon an existing relationship".48 This is exactly what Salve Deus attempts to do by establishing a closer relationship with Lady Margaret Russell (née Cooke) and her daughter Anne Clifford. Lanyer constructs within her poem a narrative of shared intimacy evoking that "faire night", when she and Russell shared a taste of "Paradice" of "pleasant groves, hills, walks and stately trees". According to Lanyer, Lady Russell asked her to write "praisefull lines of that delightful place" 49 which would become the "Description of Cooke-ham" that puts an end to Lanyer's poem. Since the early 1980s, Lanyer scholarship has tended to lay emphasis on her construction of a community of "good women". Barbara Lewalski, Elaine Beilin and Susanne Woods elaborate on Lanyer's construct of a feminist sisterhood of patrons, united by gender, virtue, love of poetry and the Protestant faith. ${ }^{50}$ Other readings by Loughlin,

44 Melanie Bigold, Women of Letters, Manuscript Circulation and Print Afterlives in the Eighteenth Century, New York 2013, 7.

45 Ibid., 8.

46 Helen Smith, Grossly Material Things. Women and Book Production in Early Modern England, Oxford 2012, 57 .

$47 \quad$ Ibid., 54.

48 Jessica Malay, “Positioning Patronage: Lanyer's Salve Deus Rex Judæorum and the Countess of Cumberland in Time and Place", The Seventeenth Century, 28/3 (2013), 251-74.

49 Woods, The Poems of Aemilia Lanyer, 51:18.

50 Elaine Beilin, Redeeming Eve: Women Writers of the English Renaissance, Princeton 1987, 177-207; Susanne Woods, "Aemilia Lanyer and Ben Jonson: Patronage, Authority, and Gender", Ben Jonson Journal, 1 (1994), 15-30; Barbara Lewalski, "Patriarchy and Patronage: Margaret Clifford, Anne Clifford, and Aemilia Lanyer”, The Yearbook of English Studies, 21 (1991), esp. issue 'Politics, Patronage and Literature in England 1558-1658', 87-106. 
DiPasquale or White interprete Lanyer's subversion of her rewriting of the Passion as illustration of her literary skills and theological wisdom..$^{51}$ In both readings, the issue of patronage appears to be inextricably linked to the construction of Lanyer as an author, regardless of the fact that she was not successful in gaining the financial or social support of her addressees. For Yerbury, her approach to writing was consistent, rigorous and personal, albeit inspired in episodes of common interest. She shunned being exposed to the public eye even though she was intent on having an effect on her immediate surroundings. For both women, as for many of their contemporary visible or invisible poetesses, their material reality almost always superseded their talent on paper.

\section{Bibliography}

\section{Primary References}

Chandler, Mary. 1730. 'On my own epitaph' in Lonsdale, Roger (ed.). Eighteenth Century Women Poets. Oxford: Oxford University Press: 152.

Colonna, Vittoria. 1557. Pianto della Marchesa di Pescara sopra la passione di Christo. Oratione della medesima sopra l'Ave Maria. Bologna: Manutio.

Lanyer, Aemilia. 1611. Salve Deus Rex Ivdaeorum. London: Valentine Simmes for Richard Bonian.

Leapor, Mary. 1993. 'The cruel parent' (1730) in Richard Green (ed.) Mary Leapor: A Study in Eighteenth-century Women's Poetry. Oxford: The Clarendon Press: 67.

Montagu, Lady Mary Wortley. 1730. 'In answer to a lady who advised retirement' in Backscheider, Paula and Catherine E. Ingrassia (eds). British Women Poets of the Long Eighteenth Century: an Anthology. Baltimore: The Johns Hopkins University Press: 688. Seager, Jane. 2006. 'The Divine Prophesies of the Ten Sibills' (ed. Jessica Malay) in English Literary Renaissance 36(2): 189-93.

Shakespeare, William. 2008. As You Like It (ed. A. Brissenden). Oxford: Oxford University Press.

Shakespeare, William. 2008. The Merchant of Venice (ed. J.L. Halio). Oxford: Oxford University Press.

$5^{1} \quad$ Micheline White, "A Woman with Saint Peter's Keys? Aemilia Lanyer's Salve Deus Rex Judaeorum (1611) and the Priestly Gifts of Women", Criticism, 45/3 (2003), 323-41; Theresa DiPasquale, Refiguring the Sacred Feminine: The Poems of John Donne, Aemilia Lanyer, and John Milton, Pittsburgh 2008; Marie H. Loughlin, "Fast ti'd unto Them in a Golden Chaine: Typology, Apocalypse, and Woman's Genealogy in Aemilia Lanyer's Salve Deus Rex Judaeorum", Renaissance Quarterly, 53/1 (2000), 133-79; Kari Boyd McBride, "Sacred Celebration: The Patronage Poems", in Aemilia Lanyer, ed. Grossman, 6o-82. 
Sidney, Philip and M. Sidney. 20o9. The Sidney Psalter (eds H. Hamlin et al). Oxford: Oxford University Press.

Yerbury, Ann. The Yerbury Papers, MS.1994.0o2, The William Andrews Clark Memorial Library in Los Angeles.

\section{Secondary References}

Adamson, Sylvia, Gavin Alexander and Katrin Ettenhuber (eds). 2011. Renaissance Figures of Speech. Cambridge: Cambridge University Press.

Backscheider, Paula R. 2005. Eighteenth-century Women Poets and their Poetry: Inventing Agency, Inventing Genre. Baltimore: The Johns Hopkins University Press.

Beilin, Elaine. 1987. Redeeming Eve: Women Writers of the English Renaissance. Princeton: Princeton University Press.

Bigold, Melanie. 2013. Women of Letters, Manuscript Circulation and Print Afterlives in the Eighteenth Century. New York: Palgrave Macmillan.

Clarke, Danielle (ed.). 2001. Renaissance Women Poets, Isabella Whitney, Mary Sidney and Aemilia Lanyer. London: Penguin Classics.

Coles, Kimberly. 2008. Religion, Reform, and Women's Writing. Cambridge: Cambridge University Press.

DiPasquale, Theresa. 2000. 'Woman's Desire for Man in Lanyer's Salve Deus Rex Judaeorum' in Journal of English and Germanic Philology 99(3): 356-78.

DiPasquale, Theresa. 2008. Refiguring the Sacred Feminine: The Poems of John Donne, Aemilia Lanyer, and John Milton. Pittsburgh: Duquesne University Press.

Ezell, Margaret J.M. 1999. Social Authorship and the Advent of Print. Baltimore: The Johns Hopkins University Press.

Fang, Su. 200o. 'Aemilia Lanyer and the Politics of Praise' in ELH, 67(2): 433-45.

Fergus, Jan. 2007. Provincial Readers in Eighteenth-century England. Oxford: Oxford University Press.

Franco, Veronica. 1995. Rime, a cura di Stefano Bianchi. Milan: Mursia Editore.

Griffin, Dustin. 1996. Literary Patronage in England 1650-1800. Cambridge: Cambridge University Press.

Grossman, Marshall (ed.). 1998. Aemilia Lanyer: Gender, Genre and the Canon. Lexington: University Press of Kentucky.

Hodgson, Elizabeth. 2003. 'Prophecy and Gendered Mourning in Lanyer's Salve Deus Rex Judaeorum' in Studies in English Literature, 1500-1900 43(1):101-16.

Lasocki, David and Roger Prior. 1995. The Bassanos: Venetian Musicians and Instrument Makers in England, 1531-1665. Aldershot: Scolar Press.

Lewalski, Barbara K. 1991. 'Patriarchy and Patronage: Margaret Clifford, Anne Clifford, and Aemilia Lanyer' in The Yearbook of English Studies, esp. issue 'Politics, Patronage and Literature in England 1558-1658' 21: 87-106. 
Lewalski, Barbara K. 1998. 'Seizing Discourses and Reinventing Genres' in Grossman (1998): 49-59.

Lewalski, Barbara. 1993. Writing Women in Jacobean England. Cambridge, MA: Harvard University Press.

Longfellow, Erica. 2004. Women and Religious Writing in Early Modern England. Cambridge: Cambridge University Press.

Loughlin, Marie H. 20oo. 'Fast ti'd unto Them in a Golden Chaine: Typology, Apocalypse, and Woman's Genealogy in Aemilia Lanyer's Salve Deus Rex Judaeorum', in Renaissance Quarterly 53(1): 133-79.

Malay, Jessica L. 2013. 'Positioning Patronage: Lanyer's Salve Deus Rex Judæorum and the Countess of Cumberland in Time and Place' in The Seventeenth Century 28(3): 251-74.

McBride, Kari Boyd. 1999. 'Sacred Celebration: The Patronage Poems' in Grossman (1998): 6o-82.

McGrath, Lynette. Let Us Have Our Libertie Againe: Aemilia Lanyer's 17th Century Feminist Voice' in Women's Studies 2o(3-4): 345-348.

Millman, Jill and Gillian Wright (eds). 2005. Early Modern Women's Manuscript Poetry. Manchester: Manchester University Press.

Mueller, Janel. 1998. 'The Feminist Poetics of 'Salve Deus Rex Judaeorum' in Grossman (1998): 99-127.

Peacey, Jason. 2013. Print and Public Politics in the English Revolution. Cambridge: Cambridge University Press.

Penelope Lane, Neil Raven and K.D.M Snell (eds). 2004. Women, Work and Wages in England, 1600-1850. Rochester, NY: The Boydell Press.

Prescott, Sarah. 2003. Women, Authorship and Literary Culture. New York: Palgrave Macmillan.

Roberts, Wendy Miller. 2005. 'Gnosis in Aemilia Lanyer's 'Salve Deus Rex Judaeorum” in Rocky Mountain Review of Language and Literature 59(2):11-28.

Rogers, John. 2000. 'The Passion of a Female Literary Tradition: Aemilia Lanyer's Salve Deus Rex Judaeorum" in Huntington Library Quarterly 63(4): 435-46.

Rowse, A.L. 1973. Shakespeare the Man. London: Macmillan.

Runge, Laura L. and Pat Rogers (eds). 20o9. Producing the Eighteenth-century Book: Writers and Publishers in England 1650-180o. Newark: University of Delaware Press.

Saunders, J.W. 2007 [1964]. The Profession of English Letters. London: Routledge.

Shea, Colleen. 2002. 'Literary Authority as Cultural Criticism in Aemilia Lanyer' in English Literary Renaissance 32(3): 386-407.

Shuger, Debora K. 1994. The Renaissance Bible: Scholarship, Sacrifice, and Subjectivity. Berkeley: University of California Press.

Smith, Helen. 2012. Grossly Material Things. Women and Book Production in Early Modern England. Oxford: Oxford University Press. 
White, Micheline. 2003. 'A Woman with Saint Peter's Keys? Aemilia Lanyer's Salve Deus Rex Judaeorum (1611) and the Priestly Gifts of Women' in Criticism 45(3): 323-41.

Wiseman, Susan. 2007. 'Exemplarity, Women and Political Rhetoric' in Richards, J. and A. Thorne (eds), Rhetoric, Women and Politics in Early Modern England. New York: Routledge: 129-48.

Woods, Susanne. 1993. The Poems of Aemilia Lanyer. Oxford: Oxford University Press.

Woods, Susanne. 1994. 'Aemilia Lanyer and Ben Jonson: Patronage, Authority, and Gender' in Ben Jonson Journal 1:15-30.

Wright, Gillian. 2013. Producing Women's Poetry, 1600-1730: Text and Paratext, Manuscript and Print. Cambridge: Cambridge University Press. 


\title{
Possibilities of Patronage: The Dutch Poet Elisabeth Hoofman and Her German Patrons
}

\author{
Nina Geerdink
}

Patronage was a common practice for many early modern authors, but it was a public activity involving engagement with politics, politicians and the rich and famous, and we know of relatively few women writers who profited from the benefits of patronage. The system of patronage altered, however, during the seventeenth and eighteenth centuries and one particular case study brings to light some of the possibilities and difficulties of this system for women writers. Elisabeth Hoofman (1664-1736) was a Dutch poet whose authorship was representative of that of many writing women around 1700: born in a rich family, she wrote poetry in order to establish and consolidate contacts in a wealthy circle of friends and family, refusing to publish any of her poems. Her authorship status seems to have changed, though, after she and her husband lost their fortune and turned to rich patrons to secure their living. The circle of people addressed in her poetry broadened to powerful men from outside of her intimate network and she started to print-publish. In this chapter, Hoofman's opportunities to contribute to the family income as a woman writer along with her ability and necessity to manage her reputation are analysed with and through her poetry.

Traditionally, Renaissance literary patronage has been regarded as a relationship between authors and patrons within the context of court culture. Patronised authors received pensions for their poetic work, which they could produce relatively autonomously, as long as their literary reputation reflected on the court and its ruler(s), and as long as their literary products could on occasion be used to amuse these ruler(s) and their guests. Although there 
were some exceptions to the rule, this traditional type of patronage did not easily suit women authors due to the public role, amongst other reasons, the patronised poet was expected to play.

In the last few decades, patronage studies have opted for a much broader definition of literary patronage, in which authors can be formally embedded within a court, and other authors and other contexts can also be integrated. ${ }^{1}$ Patronage is, in this definition, any relationship between an author and someone of a higher class or socio-economic standing in which profits are exchanged. Literary products are part of the reciprocity. This less formalised form of patronage was important in a country such as the Dutch Republic, where court culture was less rich and dominant than in other European countries. ${ }^{2}$ Throughout Europe, then, informal patronage began to play an increasingly important role during the seventeenth and eighteenth centuries. ${ }^{3}$ Patronage could lead to personal relationships of longer duration, ${ }^{4}$ but it could also easily be characterised as commercial professionalism as it consisted of, in the words of Helen Smith, "a series of separable and isolated transactions in which cultural goods are traded for money or favour". ${ }^{5}$ Authors tried their best to win patrons' favours, for example by writing occasional poems and dedicating books. ${ }^{6}$ At first sight, this less formalised configuration of patronage seemed to fit female authors better than court patronage. At the same time, the fact that these configurations of patronage were not organised formally makes it difficult to unravel them, especially in the case of women authors, who less often published their literary exchange products. ${ }^{7}$

1 S. de Beer, The Poetics of Patronage. Poetry as Self-Advancement in Giannantonio Campano, Turnhout 2013; Dustin Griffin, Literary Patronage in England 1650-180o, Cambridge/New York 1996; Helen Smith, Grossly Material Things. Women and Book Production in Early Modern England, Oxford 2012. See also Sarah Prescott, Women, Authorship and Literary Culture, 16901740, Houndmills/New York 2003, 112-15.

2 Nina Geerdink, Dichters en Verdiensten. De Sociale Verankering van het Dichterschap van Jan Vos (1610-1667), Hilversum 2012, 13-15.

3 In England, for example. J. Brewer, "Authors, publishers and the making of a literary culture", in: The Pleasures of the Imagination: English Culture in the Eighteenth Century, New York 1997, 162-63 shows informal patronage evolved as a consequence of the marginalisation of court patronage during the eighteenth century. See also Prescott, Women, 112-15. Smith, Grossly Material Things, argues covincingly it evolved even earlier, from the sixteenth century onwards, and existed next to court patronage.

4 Which is a crucial part of the definition of patronage that De Beer, The Poetics of Patronage, uses in line with Griffin, Literary Patronage.

5 Smith, Grossly Material Things, 70.

6 Ibid.

7 Cf. for example Smith, Grossly Material Things, 7 . 
In the case of the Dutch Republic, few female authors have left us reliable traces by which we can analyse their protection by a patron. One of them is Elisabeth Hoofman. ${ }^{8}$ She wrote and published several poems for the German landgrave Charles I, who supported her household for many years because Hoofman's husband Pieter Koolaart worked for him. Using the case of Hoofman, this chapter explores the benefits for and limitations placed on Dutch women writers, who required the support of a patron, but wanted to protect their literary and social reputation at the same time.

\section{Possibilities of Patronage in the Dutch Republic}

Dutch poets could profit from the protection of rich salesmen, local and provincial politicians - the very powerful regents - and the leaders of the country, among them the Princes of Orange (the so called stadholders), that in some cases did stimulate a court culture (though incomparable to the court cultures in other countries). Moreover, Dutch poets frequently had patrons abroad. The famous Dutch poet Joost van den Vondel was, for example, informally patronised by the Danish King Frederick III. ${ }^{9}$ Many Dutch authors found protection in German countries, like Hoofman. German Electors, Dukes and landgraves were willing to provide patronage in return for the creation of a positive public image by Dutch poets, who had the potential to reach an audience of Dutch politicians and were important for the German leaders. Moreover, Dutch poets brought with them the fame of the Dutch Republic, highly esteemed in the German countries. ${ }^{10}$

Relationships of patronage from Dutch authors should be regarded in terms of the broad definition of literary patronage sketched above. A direct transaction of money was not always guaranteed, but patronised poets could profit financially from their relationships with patrons in an indirect manner. For example, if their patrons arranged jobs for them, if they introduced them to networks that could be relevant for their jobs, if they invited them for dinners and

8 Other Dutch female authors that left traces of relationships of patronage are Maria Margaretha van Akerlaecken (1605-1670), Anna Maria Paauw (?-1710) and Katharina Lescailje (1649-1711).

$9 \quad$ Nina Geerdink, "De toe-eigening van een triomftocht. Het ontzet van Kopenhagen (1658) in teksten van Vondel, Vos en De Decker", in: Oorlogsliteratuur in de vroegmoderne tijd. Vorm, identiteit en herinnering, eds Lotte Jensen and Nina Geerdink, Hilversum 2013.

10 Cf. Oranien-Nassau, Die Niederlände und Das Reich, ed. Horst Lademacher, Münster 1995; Soweit der erdkreis reicht. Johann Moritz von Nassau-Siegen 1604-1679, ed. G. de Werd, Kleve 1979 . 
parties, or if they presented valuable gifts to them. ${ }^{11}$ In return, authors wrote poems in praise of their patrons and their political, commercial and cultural deeds and importance.

This kind of patronage meant very often that poets had to choose sides in a political conflict since the political landscape consisted of many different factions, with an almost continuous struggle for power between the leaders of cities, provinces and the Republic as a whole during the seventeenth and eighteenth centuries. ${ }^{12}$ This also meant that the reputation and profits of a patronised poet depended on the political position of the patron, which was far from stable. This might have enlarged the informal organisation of patronage structures, which also had to do with literary reputation. In opposition to court patronage, the broader, more dominant Dutch configuration of patronage was almost always concealed. No author would proudly highlight his relationship of patronage with any one regent, in the same way as in other European countries, Dutch authors were vocal about writing for honour alone. ${ }^{13}$

For women, these informal relationships of patronage must have been more difficult to obtain and maintain than for men, since they had fewer opportunities to become acquainted with the (male) patrons. Networking within circles of politicians and other possible patrons was not particularly acceptable for women, who were expected to stay within the domestic sphere. Moreover, the political support that most patrons wanted did not correspond with the public profile of Dutch women authors, who - only from the end of the seventeenth century onwards - carefully started to write about political themes, such as military victories, the death of people from the ruling class, or political conflicts within the Dutch Republic that sometimes led to gruesome events (such as the murder of the De Witt brothers in 1672$).{ }^{14}$ For a long time, women that sought publicity with their literary work tried to remain within the borders that their gender created, in order to protect their reputation. ${ }^{15}$ Even more

\footnotetext{
11 Geerdink, Dichters en Verdiensten.

12 Cf. Maarten Prak, The Dutch Republic in the Seventeenth Century, Cambridge 2005, esp. $166-185$.

13 Geerdink, Dichters en verdiensten, 11 . See also the introduction to this volume.

14 Riet Schenkeveld-van der Dussen, "Women's Writing from the Low Countries 1575-1875", in: Women's Writing from the Low Countries 1200-1875. A Bilingual Anthology, eds Lia van Gemert et al, Amsterdam 2010, 47.

15 Schenkeveld-van der Dussen, "Women's Writing", 49, 53. A more detailed account of the limitations to women's writing during the early modern period, and the way in which women writers presented themselves is available in Dutch, in Met en zonder Lauwerkrans. Schrijvende Vrouwen uit de Vroegmoderne Tijd 1550-1850 van Anna Bijns tot Elise van Calcar, eds Riet Schenkeveld-van der Dussen et al, Amsterdam 1997.
} 
than men, they emphasised that they did not write for profit. Women writers often did mention the intellectual support of male protectors, but not financial support. Moreover, in most cases women writers did not receive employment that made it possible for them to profit indirectly.

\section{Elisabeth Hoofman}

The possibilities and difficulties of patronage for Dutch women writers can be illustrated by the life and work of Elisabeth Koolaart-Hoofman. ${ }^{16}$ In many respects, she is representative of Dutch women writers at the turn of the century. She was born in 1664 to a wealthy, intellectual mennonite family in the blooming Dutch city of Haarlem, a town with a central position in the rich province of Holland. In the mennonite circles she grew up in, the arts were held in high esteem. ${ }^{17}$ She thus had the necessary possibilities to write poetry: free time, intellectual stimuli and enough money to buy writing materials. She is said to have written her first poems when she was only six, and by her sixteenth year, she wrote poems in Latin. She learned Greek and Latin from a tutor at home. One of her two brothers wrote plays.

Most of Hoofman's poetry, however, is written in Dutch and meant for family, friends and acquaintances, such as her teacher and other female authors in her network. It is so-called social poetry, written on the occasion of birthdays, marriages, other festivities and gifts. Exceptions are translations of poems by Horace, some religious and meditative poems, two country house poems about the country house of Hoofman's own family and the rather atypical poem "Schouwburg des doods" (Theatre of Death), a melancholic sketch of the vanity of the world.

A selection of Hoofman's poetry was published after her death in the Naagelaatene gedichten (Postuum Poetry, 1774$).{ }^{18}$ Her daughter and son-in-law

16 Biographical information in this section is based on recent archival research, presented in W.R.D. van Oostrum, "Hoofman, Elisabeth", in: Digitaal Vrouwenlexicon van Nederland, http://resources.huygens.knaw.nl/vrouwenlexicon/lemmata/data/Hoofman; Lia van Gemert, "Victim of Distortive Editing. Elisabeth Hoofman, Haarlem 23 February 1664 - Kassel, 4 July 1736', in: Women's Writing from the Low Countries.

17 For references to literature about mennonite culture in the Dutch Republic in the later seventeenth century see Nina Geerdink, "The Appropriation of the Genre of Nuptial Poetry by Katharina Lescailje (1649-1711)", in: Women Writing Back/Writing Women Back, eds Anke Gilleir, Alicia C. Montoya \& Suzan van Dijk, Leiden/Boston 2010, 182.

18 Elisabeth Koolaart-Hoofman, De naagelaatene gedichten van Elisabeth Koolaart, geboren Hoofman, ed. W. Kops, Haarlem 1774. 
finished the manuscript collection of her poems that she herself started to arrange shortly before she died. They wanted to publish it, but had neither time nor money. In vain at first, they tried to arrange a publication in the Dutch Republic through a former friend of the family. After this friend died, the request of Hoofman's daughter came into the hands of a young man from Haarlem, Willem Kops, who as the son of former family friends showed some interest and chose some 3 o poems from the collection to publish in a printed volume. He rewrote parts of these poems in order to meet the strict formal conventions of the day. ${ }^{19}$ Some of the original poems are still in the manuscript collection that Hoofman's daughter finished together with her husband. Unfortunately, not everything survived. In the contents list of the handwritten collection (see figure 6.1), 120 titles are mentioned, ${ }^{20}$ of which only 61 poems survived..$^{21}$

During her lifetime, Hoofman did not want to publish her own work and presented herself modestly. So, in this respect too, she was like other early modern women writers. ${ }^{22}$ This appears most clearly in her correspondence with Theodorus Janssonius van Almeloveen (1657-1712), a professor of letters and arts in Harderwijk, a university town in the province of Guelders. Van Almeloveen repeatedly asked Hoofman to write poems to include in his publications, which she continuously refused. Hoofman sometimes wrote poems for him, but she emphasized that they were not to be published. She reacted angrily when it surfaced that Van Almeloveen did publish one of her poems against her wishes, and even when he mentioned that someone had read her poem out loud in public, she was not amused. ${ }^{23}$

In contrast to many other female Dutch poets, ${ }^{24}$ Hoofman continued writing after her marriage. In 1693, she married the wealthy Haarlem merchant

19 Van Oostrum, "Hoofman, Elisabeth".

20 Since some of the titles refer to several poems, the total number of poems must have been even higher.

21 Katrien Timmers compared the contents of the collections accurately in Katrien Timmers, Uit het loof van Poesij. Elisabeth Koolaart-Hoofman (1664-1736), master's thesis Utrecht University, 1994.

22 Cf. for example Patricia Pender, Early Modern Women's Writing and the Rhetoric of Modesty, London/New York 2012.

23 Saskia Stegeman, Patronage en dienstverlening. Het netwerk van Theodorus Janssonius van Almeloveen (1657-1712) in de Republiek der Letteren, Nijmegen 1996, 65-66.

24 Schenkeveld-van der Dussen, "Women's Writing", 53. About Hoofman and other exceptions to the rule, I wrote a guest blogpost with some preliminary findings: Nina Geerdink, "The Phenomenon of the Married Woman Writer in the Dutch Republic", in: Early Modern Women: Lives, Texts, and Objects, https://martinevanelk.wordpress.com/2017/11/o1/ the-phenomenon-of-the-married-woman-writer-in-the-dutch-republic/, ed. Martine van Elk, 2017 . 


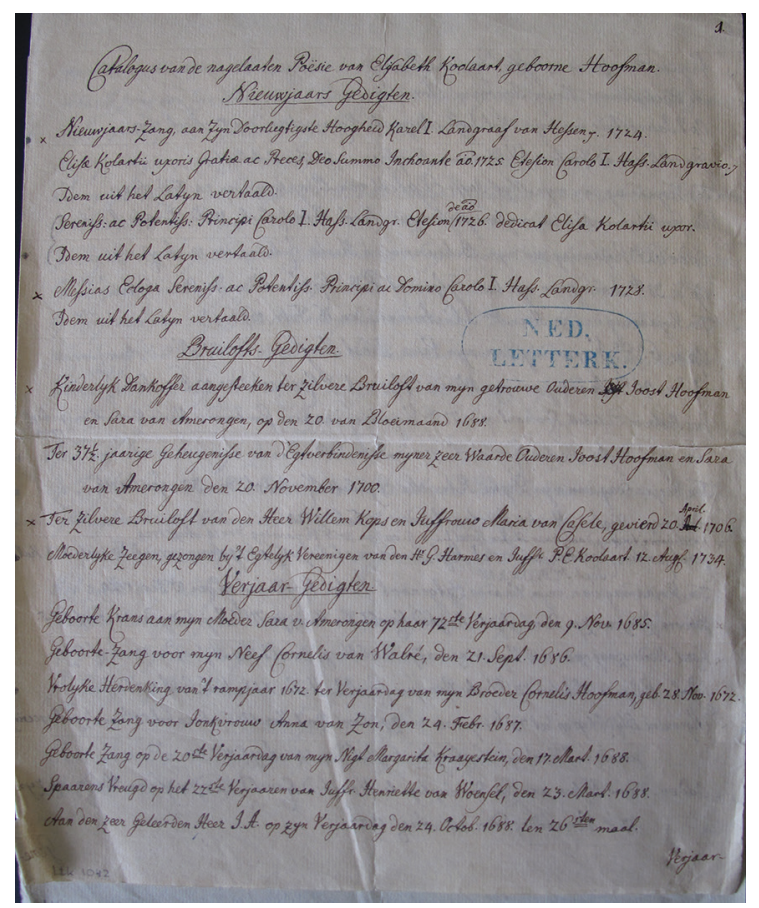

FIGURE 6.1 First page of the contents list in Hoofman's manuscript collection. Universiteitsbibliotheek Leiden, hs. LTK 1042.

Pieter Koolaart. He was known as a lover of the arts. That her husband was held in high esteem appears, for example, from the fact that the Russian Czar Peter I (the Great) and his wife Catharine I visited the family in Haarlem in 1717. Koolaart brought to the relationship a 10-year-old daughter from an earlier marriage, Hester. She was deaf and a mute, and - with the help of a doctor who would become famous for his treatment of the deaf, John Conrad Amman (1669-1724) - Hoofman taught her to write and communicate. During her marriage, Hoofman gave birth to one daughter, named Petronella. So far, so good.

The tide turned in 1717, the same year Czar Peter I visited the Koolaart family. Most likely because they lived beyond their means, the couple encountered financial troubles and decided to move to a less expensive house in the village of Lisse, nearby Haarlem. In 1721, Pieter Koolaart was offered a job in Germany, in the retinue of the landgrave of Hesse-Kassel, Charles I. This seemed a good opportunity to solve their financial problems and so he moved there. Elisabeth followed him to Kassel in May 1722. Pieter Koolaart worked as Charles' Kommerziendirektor, which meant that he was responsible for the Hesse-Kassel 
trade. ${ }^{25}$ He earned 1600 guilders each year. In 1730, the landgrave died and Koolaart lost his job, but he could still take care of his family from the pension he received, although this was only half of his original salary: 800 guilders. This ended when he died himself, in 1732. After her husband's death, Elisabeth Hoofman had to take care of herself and her daughter. Hester, the deaf daughter of her husband, had a small yearly income. Some family members, cousins, made sure Hoofman and her own daughter also received some money, but this did not amount to anywhere near 800 guilders. In 1734, her daughter Petronella married the son of the Kassel's courtpublisher, therewith solving or at least deminishing the money problems. Petronella and her husband lived with her mother and half-sister Hester.

As a widow, Hoofman stayed in Kassel until she died in 1736. At that moment, she had been busy collecting the poems she wrote throughout her life. It was this manuscript collection that her daughter and son-in-law finished and which would be the basis for the publication of her poetry some 40 years later. In the biographical sketch that preceded the anthology of 1774, much attention was paid to the misfortune of Hoofman, who was portrayed as a victim of the financial incapabilities of her husband. It is this image that has survived as a significant foundation for maintaining interest in Hoofman's small oeuvre. ${ }^{26}$ Only recently, archival research has shown that Hoofman was not a victim of her husband, but that she herself was also responsible for the financial troubles. ${ }^{27}$ Be that as it may, the fact that Hoofman's financial situation changed during her lifetime, throws light on interesting questions regarding her authorship. Hoofman's meditative poetry has been interpreted autobiographically as lamenting about her misfortune, but this seems inaccurate as she also wrote this kind of poetry in times of prosperity. What, then, were the consequences of the changed financial situation for Hoofman's poetry?

\section{Poetry in Times of Financial Decline}

There are two changes in Hoofman's authorship after 1717 that cannot be overlooked: she started to write poetry for people outside her intimate circle and she seemed less reluctant to publish her own poems.

\footnotetext{
25 Hans Philippi, Landgraf Karl von Hessen-Kassel. Ein Deutscher Fürst der Barockzeit, Marburg $1976,672-73$.

26 Cf. Timmers, Uit het Loof van Poesij, 45-76.

27 This appears from letters from Hoofman's daughter Petronella to a.o. Willem Kops (Leiden University Library, sign. LTK 1004), studied by Van Oostrum, "Hoofman, Elisabeth".
} 
The new addressees of Hoofman's poems after 1717 are the landgraves of Hesse-Kassel: Charles I (1654-1730) and his sons and successors William (1682-1760), to be William VIII, and Frederick (1676-1751), to be Frederick I of Sweden. Frederick was the successor of his father but was engaged with the Kingdom of Sweden, which made William VIII, as a regent, the actual leader of Hesse-Kassel after the death of their father. As far as we know, Hoofman had written 19 poems for the father and his sons between her husband's arrival in Kassel in 1721 and her death in 1736. Eighteen of these poems have survived, in handwriting, contemporary print or in Kops' posthumous publication. ${ }^{28}$ It cannot be a coincidence that this new circle of addressees were the financial caretakers of her family. At least up until 1732 that is. After the death of her husband, and the major decrease in income this caused, Hoofman hoped in vain for some kind of continuation of the support of the House of Hesse-Kassel. ${ }^{29}$

The publication history of her poems supports this hypothesis. Apart from some Latin poems that were published without her involvement and against her wishes, Hoofman print-published only two poems before 1717. The first one, "Kinderlyke dank-offer Aangesteken ter zilvere bruyloft, Van mijn getrouwe ouderen, Joost Hoofman en Sara van Amerongen. Op den 2osten van Bloey maand 1688" (A child's thanks-offering, lighted on the occasion of the silver wedding anniversary, of my faithful parents, Joost Hoofman and Sara van Amerongen, at the 2oth of May 1688), on the occasion of the silver wedding anniversary of her parents thus, she wrote, as appears already from the title, from the perspective of a daughter of celebrating parents. Hoofman was unmarried and living with her parents when she wrote this poem, and it is quite possible that the publication was a present for her parents, maybe also on behalf of her two younger brothers (her younger sister had died in 1682, aged 17). The poem was published by Jan Gerritsz Geldorp, a Haarlem publisher active from 1665169o. He might have been familiar to the Hoofman's, as he published nuptial poems for couples from Haarlem's mennonite circles, to which the Hoofman's belonged. Elisabeth's private teacher, Jacob Storm, also published many poems with Geldorp's widow, who ran the publishing house from $1695^{-1720.30}$ The second poem Hoofman published herself before 1717 was a nuptial poem, on the occasion of the silver wedding anniversary of her parents' friends, Willem

28 The poem that I could not find is a New Year's song from 1725. It is one of the poems that is mentioned in the table of contents of the manuscript collection, but not included.

29 This appears from the letter from Petronella to Van Zanten, 23 June 1747 (Leiden University Library, sign. LTK 1004).

30 Cf. Short Title Catalogue of the Netherlands (sTCN, http://picarta.pica.nl), s.v. printer/ publisher: 'Geldorp, Jan Gerritsz.' and 'Geldorp, Jan Gerritsz. Wed.. 
Kops (grandfather of the later editor of her published works) and Maria van Casele, in 1706. This poem was published in a small booklet with two other nuptial poems on the same occasion, one of these by another member of the Geldorp family, and printed with the same publishing house (the widow of Geldorp).

After 1717, Hoofman published a nuptial poem on the occasion of the marriage of her own daughter in 1734, as well as a small collection with religious poetry at the request of her new son-in-law, ${ }^{31}$ a birthday poem for her cousin Margareta Kraayestein in 1736, and 8 poems addressed to landgrave Charles I and his sons and successors William VIII and Frederick I of Sweden, between 1726 and 1736. It cannot be a coincidence that Elisabeth put her reservation for publishing aside in the period that her financial situation was difficult, while the poems she wrote and published were almost all of them addressed to people who helped her financially or were able to do so. This not only accounts for the landgraves, but also for her cousin Kraayestein, who supported Hoofman financially after 1732, and for her son-in-law, who by marrying her daughter had relieved her financial troubles. For the rest of this chapter, I will analyse the poems Hoofman wrote for her financial caretakers in order to draw some conclusions about the role her poetry played in the relationship with her supporters and in the management of her reputation.

\section{Patronage from the House of Hesse-Kassel}

Even before Hoofman had arrived in Kassel herself, she wrote her first poem to her husband's new lord. The Latin version of the poem, in Dutch titled "Aan syn doorlugtigste hoogheyd Karel de eerste" (To his Illustrious Highness Charles the First"), is dated $1721 .^{32}$ In the poem, she introduces herself and her daughters to the landgrave. It comes as no surprise that she praises Charles' person and writes that she hopes he will rule in Hesse-Kassel for a very long time, and moreover, that his family will rule there forever. As evident from the poem, it accompanied a gift for the landgrave: a book by John Conrad Amman, the famous doctor who had taught Hoofman's deaf stepdaughter Hester to communicate. It is a meaningful gift for a ruler that Hoofman calls in her poem

31 This collection, Gedagten over eenige spreuken des allerwysten konings Salomon, mitsgaders uit zyn Prediker \&c., was printed by Georg Harmes (most probably in his father's publishing house, that he would continue after his father's death in 1737) on his own request, as appears from the dedication to Hoofman's brother and her friends at home. 
one who "supports and favours science, and all valuable arts, perseveringly". ${ }^{33}$ While writing that she hopes to find some rest and peace in Kassel in her old years, Hoofman of course also recommends her family to him, as they were known to be lovers of science and the arts themselves, and, more specifically, she recommends herself to him as a poet.

It did not immediately result in contact between Charles I and the Koolaart family, or at least it does not appear so based on Hoofman's poetry, as the next poem she wrote for Charles I is dated 3 years later, in 1724. ${ }^{34}$ In January, Hoofman wrote him a "Nieuwjaarszang" (New Year's Song), written in Latin and translated in Dutch. It became a tradition she would continue for the next few years, up until 1728 . Only the last one of these poems, the pastoral song Messias with which she celebrated the start of the year 1728 , survived in contemporary print. We do know how the 1724 and 1726 New Year's Songs might have sounded though, as they are included in the collection Willem Kops made of Hoofman's poems in $1774 .{ }^{35} \mathrm{He}$ must have had manuscript versions that did not survive. The poems thank God for everything he has brought at the year's close and ask for a good new year, especially for Charles I and his offspring. In the last lines of the 1724 poem, Hoofman explicitly mentions how his good deeds inspire her as a poet.

Following the New Year's poem, Hoofman wrote a second poem for Charles I in 1724. It was a special year for the landgrave as he reached the age of 70. Charles' birthday on 14 August prompted Hoofman to write a long ode to the landgrave's newly built city for huguenote refugees from France. The city was called Karlshafen (nowadays Bad Karlshafen), as was Hoofman's poem. Again, she wrote it both in Latin and in Dutch, but unlike the New Year's poem, she published the Dutch version. It is the only poem that I could retrace in a German context (the archive of Nordrhein-Westfalen). ${ }^{36}$

33 "wetenschap, en alle nutte konst/Trou en standvastig bied u hulp en gonst".

34 Other sources seem to be scarce. German archives of the court and the family (in the Hessisches Staatsarchiv Marburg) only contain some documents regarding Koolaarts job, but no documents with Hoofman's name or works mentioned in it (browsing s.v. the online searchtool Arcynsis s.v. Hoofman, Koolaart, and Koolaert).

35 Koolaart-Hoofman, De naagelaatene gedichten, 87-91;103-8.

36 It is unclear in which language she presented the poem to landgrave Charles I. In the manuscript collection, only a Dutch prose translation survived, full of references to the Latin poem. Hoofman's later editor Willem Kops presents the poem both in Dutch and in Latin. The Dutch poem survived in print in the Landesarchiv NRW: 'Lobgedicht auf Landgraf Karl I. von Hessen-Kassel und Karlshafen von Elisabeth Koolaart ndl. 1724', in Abteilung Westfalen, 4.4.2. (Sammlungen von Vereinen, Institutionen und Firmen), 4.1, V508-41, Sammlung Ferdinand F.A. Tyrell, 'Gedichte, Leichenpredigte'. 
The poem presents the landgrave as a beloved ruler, both from the perspective of other political leaders as from that of scientists and the inhabitants of Hesse-Kassel. She writes that he is an honest man, a brilliant soldier, a smart negotiator for peace, a moral example and a supporter of the arts and the sciences. Mentioning this last characteristic of the perfect renaissance ruler, Hoofman also refers, not surprisingly, to her own work. She makes that explicit when she asks Charles to support her literary work, especially this particular poem she has written for him. The phrasing she chooses is fairly conventional and there is no reason whatsoever to assume she thinks about financial support here. Still, the poem can be read as an incentive for Charles I to keep Pieter Koolaart in his service and thus to continue the financial support of the family.

The central theme of the poem is the coming into being of the city of Karlshafen, which Hoofman describes as down to Charles' merit. In a mythologically inspired narrative, Hoofman describes how he has built the city out of nothing and given it promise for the future. Hoofman represents Karlshafen as a centre of trade and business, and praises Charles I for his decision to create a city for business men. Since her husband was in charge of trade in the service of Charles I, she emphasises Koolaart's significance. Moreover, Hoofman refers to the fame and importance of Dutch trade twice, while her husband was hired in the first place because he was a Dutchman and Charles wanted to profit from the Dutch experience in trade. ${ }^{37}$

The two references to the Dutch Republic play an important role in the poem. The first reference appears in an argument about how trade and wealth create fame and power for cities and countries. The Dutch Republic serves as the perfect example; the country is small, but as a result of its successful trade, is still able to be a global leader. The second reference is made when the personification of Fortune speaks and wishes that Karlshafen would be the 'Queen' of Germany. Fortune makes her audience look back at the origins of Amsterdam, the famous city that began as a village of fishermen, in order to prove that development from nothing to all is quite possible.

We can safely assume that the poem "Karelshaven" as well as the New Year's poem from 1724 were received well by Charles, as Hoofman continued to write him such songs and birthday poems in the following years. ${ }^{38}$ Moreover, "Karelshaven" is the first of her poems for Karel I that survived in print. From that point onwards, more of her poems were printed. In 1726 Charles thanked

37 Philippi, Landgraf Karl von Hessen-Kassel, 672.

38 Some of these we only know of because they were published in Kops' edition, where we find the new year's songs of 1724 and 1726 and the birthday song's of 1725 and 1726 . (Koolaart-Hoofman, De naagelaatene gedichten, 87-91; 103-8; 95-102; 109-16.) 
Hoofman for her birthday poem with a valuable, silver gift. This appears from a poem that we only know in Kops' version, since it did not survive in handwriting or contemporary print. ${ }^{39}$ Hoofman wrote it in order to thank Charles for his gift. It also appears from this appreciative poem that she received the gift in return for her 1726 birthday poem, a pastoral song praising Charles. ${ }^{40}$

We do not know whether Hoofman's poems were printed at the initiative of the landgrave or his retinue, or if Hoofman paid for the printing herself as part of the gift for the landgrave. It is very likely, though, the Kassel's court printer Harmes printed the poems himself. Although, no single poem bears the name of a printer, the font and initials (capital letters) used are characteristic of Kassel printers. ${ }^{41}$ The hypothesis that the Kassel printer of the poems must have been the court printer is reinforced by one of the letters from Hoofman's daughter Petronella. She writes that her family was acquainted with her later husband, Georg Harmes (son of the Kassel's court printer and, from the death of his father in 1737 onwards, court printer himself), from around 1726, while the first print-poem for the landgrave we know of dates from 1724 and the number of printed poems increases from 1726 onwards. ${ }^{42}$ If the court printer indeed executed the printing of Hoofman's poems, this means that the landgrave endorsed it. Since the poems are printed in Dutch, I assume they were meant for a wider Dutch readership, in order for the landgrave to broadcast his name and fame in the Dutch estates that were of major importance for his mercantile ambitions. ${ }^{43}$

The poems Hoofman wrote from 1726 onwards conventionally praise Charles as a sincere ruler and a lover of science and the arts. In the poem she writes in 1727 on the occasion of the entry in Kassel of his newly wed granddaughter Anna Charlotta Amalia and her husband, she chose the perspective of the caring and loving grandfather. ${ }^{44}$ From the poem "Dubbeld vreugdefeest"

39 Koolaart-Hoofman, De naagelaatene gedichten, 117-19.

40 This poem too only survived in the collection by Kops: Koolaart-Hoofman, De naagelaatene gedichten, 109-16.

41 I am very grateful to Paul Dijstelberge, book historian and expert in analytical bibliography, especially the use of initials and font types, who studied Hoofman's publications and came to this conclusion.

42 She writes that the family had been acquainted with her husband ca. 8 years before they married in 1734, which means from ca. 1726 onwards. Petronella to Van Zanten, 23 June 1747 (University Library Leiden, sign. LT K 1004).

43 The importance of the Dutch Republic for Charles I appears from Claudius Sittig, "Kassel", in: Handbuch Kultureller Zentren der Frühen Neuzeit, part I, eds Wolfgang Adam \& Siegrid Westphal, Berlin/Boston 2012, 1037-91, 1044. The fact that the print-publications nowadays are primarily available in Dutch collections (in Leiden), could also point at Dutch circulation rather than German.

This poem only survived in the manuscript collection. 
(Party of Double Joy) - written in the same year, 1727, when Charles not only celebrated his 73rd birthday, but also his 5 oth year as a landgrave - it appears that Hoofman was invited to the party he held to celebrate these occasions in one of his gardens near Kassel. In this poem, she describes this joyous event and the happiness not only of the invitees, but of all the inhabitants of HesseKassel, and many more. ${ }^{45}$ The poem Hoofman wrote and published on the occasion of Charles' 74th birthday, a year later, shows how at this stage she was able to address his subjects as her public: "Hesse, give sympathetic audience to me, too". ${ }^{46}$ At the end of the poem, she presents herself as part of the audience and invites Charles to listen to the birthday song, which they sing for him all together, both "natives and foreigners" ("ingeborenen en vreemdelingen") - reference to not only herself, but the whole of the international community in Hesse-Kassel, consisting mostly of French huguenot refugees and Dutch tradespeople. ${ }^{47}$ She also identifies herself with the people of Hesse in a poem she wrote when Charles' son William was severely ill in 1728: frightened during his illness and relieved after his recovery. ${ }^{48}$ Again, she presents Charles as a very human and family-oriented person, referring to the many losses of his children he endured earlier.

Hoofman's poetical address to landgrave Charles I shows how she tried to get into his favour from the moment she arrived in the landgraviate, and how she grew in confidence as the years went by and as Charles showed his approval. She then started to publish her poems (or at least gave her permission for them to be published) and represented herself more and more as a spokeswoman for the whole land of Hesse-Kassel. This is also how she appears in the "Lykzang" (Funeral Song) she wrote and published on the occasion of the death of the landgrave on 23 March 1730. Immediately, in the first lines of the elegy, she speaks to Hesse and encourages the land to mourn with her their shared landlord: "Help, o Hessen, please help me cry/for our landlord is dead". ${ }^{49}$ In the middle and last part of the song, Hoofman addresses Charles' sons. This is remarkable as she does not mention them in her previous odes for Charles (except for the one poem she wrote for William when he was ill in 1728). In the second canto (the 'antistrophe'), she thanks God for the fact that Charles did

45 Moreover, Hoofman apparently wrote a separate poem on the occasion of Charles' birthday, meaningfully titled "Oud en nieuw Hessen" (Old and New Hesse). In this poem too, she presents herself as one among the inhabitants of Hesse-Kassel. It only survived in the edition of Kops: Koolaart-Hoofman, De naagelaatene gedichten, 120-27.

46 "Hessen, leen my gunstig mee uw ooren".

47 About this community: Sittig, "Kassel".

48 This poem only survived in the manuscript collection.

49 "Help, o Hessen, help me schreyen/onzen landheer is verscheyen". 
not leave her and the inhabitants of Hesse-Kassel with nothing, but instead with able descendents. In the concluding canto, she speaks to Frederick I and asks him to accept the 'crown' of Hesse-Kassel and follow in the footsteps of his father. It is very probable that she meant this also as an encouragement for Frederick to maintain the relationship with her family. ${ }^{50}$

Her efforts were to no avail, however, and Pieter Koolaart lost his job. He did receive a small pension, but this amounted to a decrease of the family income by 50 percent for which Hoofman obviously felt the need to retain and to increase, if possible. ${ }^{51}$ At least that is what her poem addressed to the new landgrave suggests. She wrote and published a poem for Frederick I as soon as he arrived in Hesse in 1731 , for the first time after his father's death. ${ }^{52}$ Hoofman praises his return to Hesse as a sacrifice he, as the busy King of Sweden, makes for his own people. Presenting herself as the spokeswoman of these people, she thanks him for it. She praises Frederick extensively for the (military) successes of his Swedish kingship, but she also emphasises, as she did in the elegy for Charles, that she hopes he will show the same virtues as his father did.

It turned out that Frederick's visit in 1731 was non-recurring. He left his brother William in charge of Hesse-Kassel as regent and stadholder. This meant that Hoofman had to turn to him if she wanted to maintain the relationship with the court and possibly procure her husband more income. Remarkably, there are no poems addressed to William until 1734. In the meantime, Hoofman's husband had died and the pension of the landgraviate had stopped. Hoofman had asked for a widow's pension and according to a letter by her daughter she had been promised one, but never received it. ${ }^{53}$ It is meaningful that Hoofman wrote her first poem for William in the same year Petronella married courtprinter Harmes. This possibly gave Hoofman more confidence in her approach to William and, in any case, increased her access to a printing press. Moreover, since her son in law's income depended on the court, her praise for the landgrave functioned like it did when Koolaart was still alive: as an insurance of

$5^{\circ}$ As far as we know, relationships of patronage were not conventionally passed onto heirs, cf. Geert Janssen, Creaturen van de macht. Cliëntelisme bij Willem Frederik van Nassau (1613-1664), Leiden 2005, 35, and references in note 6 on that page.

$5^{1}$ It is possible that Koolaart did not know about the continuity of his job until after Frederick came to Hesse-Kassel. If this is the case, Hoofman wrote her poem in a period of uncertainty, but with more hope probably than when she already knew her husband had lost his job.

$5^{2}$ This poem was translated from Latin.

53 Petronella to Van Zanten, 23 June 1747 (Leiden University Library, sign. LTK 1004). 
the family income, even while she might have given up hope for a widow's pension.

Hoofman's 1734 poem to William was on the occasion of his birthday. The poem was published as a pamphlet and praises William as Frederick's substitute; thanks to William, Frederick is able to concentrate on Swedish affairs. In the poem, she seems to justify the fact that she did not write for William earlier, explaining how she, being a woman, is not the right person to praise military deeds:

But easily, be quiet my zither, you are not used to make music on this high tone.

A male voice should trumpet the deeds of William.

A woman is afraid for the poundering of fusils.

This weak sexe is better fit for sending

Lamentations for him to heaven. ${ }^{54}$

It is a conventional argument, of course, but she uses it strategically by constructing an image of benevolence in her patron. ${ }^{55}$ Perhaps she even refers to her 1734 publication of religious poetry in the last two lines. ${ }^{56}$ At the same time, it might be true that Hoofman had had difficulties continuing the relationship of patronage with William, who was engaged in military business much more so than his father. William was in service to the army of the Dutch Republic and General of the army of Hesse-Kassel.${ }^{57} \mathrm{He}$ was often away during wars. This made him less accessible, and less easily praised by Hoofman, who had praised Charles specifically for his cultural and scientific interests, his trade policy and his paternal outlook toward the inhabitants. Moreover, since Hoofman's husband had died, she no longer had direct access to the network that came with Dutch trade, which she could have given William access to, and which had also allowed her to disseminate her poetry to his advantage.

54 't Jaargetyde van zyn doorlugtigste hoogheid Wilhelm. 'Maar zagt, houw stil mijn cither, niet gewoon/Te snaaren op zo'n hoogen toon./Een mannenstem moet Wilhelms daân trompetten./Een vrouw vert'saagd op 't balderen der musketten./Dat week geslagt past beter wee en zugt/Voor hem te zenden naar de lugt.'

55 Pender, The Rhetoric of Modesty, convincingly argues that tropes of modesty in early modern women's writing should not be interpreted literally too easily, but as part of strategical self-fashioning.

56 Elisabeth Koolaart, Gedagten over eenige spreuken des allerwysten konings Salomon, mitsgaders uit zyn Prediker \&c., [Kassel] 1734. [University library Leiden, sign. 1105 G 12]

57 Wolf v. Both \& Hans Vogel, Landgraf Wilhelm VIII. von Hessen-Kassel. Ein Fürst der Rokokozeit, München/Berlin 1964. 
These difficulties also seem to have played a role in the other two poems Hoofman wrote for William, both in 1736. She wrote a poem in March, on the occasion of his birthday, and one in April, on the occasion of his inheritance of the landgraviate of Hanau. Only the first of these two poems has survived in print. In both poems, Hoofman's presence in subdued. She presented herself as an acquantaince and as a spokeswoman for the people of Hesse in the poems she wrote for Charles, whereas in these poems for William she scarcely writes in the first person and does not refer to her own engagement in the described events and festivities. In the published poem on the occasion of his birthday, she again refers to her own preference not to write about military themes. Now that peace is upcoming, ${ }^{58}$ she writes, she found her voice again and she is able to praise William. Again, the trope is used strategically, since Hoofman in this way both excuses herself for not writing more for William in the past two years and presents herself as a poet to rely on in the following years of peace, in which she expected William to be in Hesse-Kassel more frequently. Moreover, she not only praises William, but also his daughter and his son, who were engaged in the "useful sciences" ("nutte wetenschappen"). As far as we know now, William did not respond to the poems addressed to him and shortly after she had started to try to renew a relationship with the landgraviate, Hoofman died herself.

\section{Family Support}

Although Hoofman's financial supplies from the landgraviate ran dry, she still received some income through family support. Several members of her family gave her money on occasion, and two of her cousins supported her structurally with 100 guilders a year each..$^{59}$ These cousins, Margareta and Maria Kraayestein, were praised in several of Hoofman's poems. Hoofman had written a fairly conventional birthday poem for Margareta in 1688, long before she could even imagine that she would eventually need any financial support. She started writing birthday poems for her again in 1734, two years after Koolaart died and when she needed Margareta more than ever. In that same year, she wrote a

$5^{8}$ Probably the peace that would conclude the war between the German emporer and France (part of the War of the Polish succession), of which the preliminaries were signed 3 October 1735. About the peace that would conclude the War of the Polish succesion was being negotiated from 1735 onwards.

Petronella to Van Zanten, 23 June 1747 (Leiden University Library, sign. LTK 1004). 
birthday poem for Maria Kraayestein. In 1736, she again wrote a birthday poem for Margareta, and this time, she also published it. ${ }^{60}$

These poems, written between 1734 and her death in 1736, are evidently related to the financial support. In the 1734 birthday poem for Margareta, Hoofman writes that she blesses her cousin twice, because she "helps her relatives in distress" ("naasten helpt in nood"). In the poem for Maria, Hoofman elaborates on the financial support:
If she, full of compassion, since she knows the help makes a difference, from her rich fortune generously helps and gives. ${ }^{61}$

Hoofman thus had economic imperatives for writing these poems. They functioned in a completely different way than the poems for the landgraves, though. In the early modern period, it was regarded as a duty to help relatives in distress. ${ }^{62}$ Therefore, Hoofman could write more explicitly about the money she received. In the case of the informal relationship of patronage with the landgraves, she did not receive money directly, but she was able to profit financially. Whereas the poems for the landgraves can be regarded as attempts to consolidate and even improve the author's financial situation, the poems for her cousins should likely not be regarded as attempts to garner more financial support, but rather as a letter of thanks in the form of a poem. That Hoofman decided to publish the last birthday poem she wrote for Margareta could very well have been motivated by her wanting to do something in return for the support. The value of the gift increased by printing it and since her daughter had by then married a printer, it probably was neither difficult nor costly for her to arrange this.

The same accounts for the publications she wrote and published as a gift for her son-in-law, the son of the court printer. Hoofman praised the marriage between Georg Harmes and her daughter in a nuptial poem that was published in a small booklet together with a poem by Petronella's half-sister

6o Next to the poems mentioned here, it appears from the catalogue in the manuscript collection that Hoofman wrote two more birthday poems for her cousins, one for Margareta in 1691 and one for Maria in 1735. These poems did not survive.

61 'Als zy vol van mededogen,/daar zy weet dat hulpe scheeld,/uit haar rijkelijk vermogen/ rijklijk helpt en mededeeld.'

62 Cf. for example Luuk Kooijmans, Vriendschap en de Kunst van het Overleven in de Zeventiende en Achttiende eeuw, Amsterdam 1998. 
Hester and two poems by the bridegroom's German friends. She also let Harmes print some of her religious poems as he had apparently requested. In the nuptial poem, the same tone of gratefulness can be distinguished as seen in the poems for her cousins, although Hoofman does not frame her gratitude in financial terms.

\section{Finances and Poetics}

Hoofman's authorship was influenced by her financial situation, but not in the way literary historians have hitherto assumed. Hoofman was, like many women writers around 1700 , very careful with her reputation. She only began publishing when she deemed it necessary to protect the income of her household. She then initiated and maintained a relationship of patronage in which she dedicated many poems to her patron, some of which were published so that they could publicly - especially in the Dutch Republic - emphasise his good deeds and importance. Except for one valuable silver gift, we know of no direct gifts or transactions from the landgrave to Hoofman. Social imperatives prevented Hoofman from receiving money directly. In order to really profit from the relationship financially, she instead needed her husband, whose salary, and later pension, could be regarded as the favour in return.

Hoofman's relationship of patronage functioned in a court context, but was not formalised. This means that time and again, Hoofman needed to show her availability and benevolence, which made her deeds almost commercial. At the same time, the relationship between her (family) and the landgrave seems to get more personal over time. It remains a question as to whether Hoofman could and would also have been able to use her poetry to ensure the family's income if she and her husband had stayed within the Dutch Republic. HesseKassel offered some advantages for a Dutch woman writer to be patronised, in the fact that she - being a Dutchwoman with a network in the Dutch Republic - brought something desirable for the landgrave and the landgraviate. It was also an advantage that she was not required to take a stance in political issues, while the landgrave had a firm position and was focused mainly on trade and science. The difficulties Hoofman faced to continue her relationship of patronage with Charles' sons seem to have been caused in part by their political and military worries and the fact that it was unclear who of the two sons she was meant to turn to. When Hoofman did not succeed in profiting from a relationship with the sons of her former patron, she relied on, as was socially accepted by, her (future) family. 


\section{Bibliography}

\section{Primary References ${ }^{63}$}

Harmes-Koolaart, P.E. several letters (in handwriting), to Van Zanten (1747) and to Willem Kops (1751). [University Library Leiden, sign. LTK 1004]

Koolaart-Hoofman, Elisabeth. Nederduitsche en Latijnsche gedichten van Elizabeth Koolaart geboorne Hoofman, benevens een catalogus harer nagelaten poëzie. (Manuscript collection.) [University Library Leiden, sign. LTK 1042]

Koolaart, Elisabeth. 1734. Gedagten over eenige spreuken des allerwysten konings Salomon, mitsgaders uit zyn Prediker \&c. [Kassel: Georg Harmes]. [University Library Leiden, sign. $1105 \mathrm{G} 12$ ]

Koolaart-Hoofman, Elisabeth. 1774. De naagelaatene gedichten van Elisabeth Koolaart, geboren Hoofman, ed. W. Kops. Haarlem:Jan Bosch. [University Library Leiden, sign. 709 D 21]

\section{[Separate Poems]}

'Geboortezang op de twintigste verjaardag van mijn Nicht Margarita Kraayestein, den 17 van Lentemaand des jaars 1688', in: Manuscript collection, 8or-8ov. Kinderlyke dank-offer Aangesteken ter zilvere bruyloft, Van mijn getrouwe ouderen, Joost Hoofman en Sara van Amerongen Op den 20sten van Bloey maand 1688. Haarlem:J.G. Geldorp [1688]. [University Library Leiden, sign. PORTEF qu 8:20]

'Ter zilveren bruiloft van den heere Willem Kops en juffrouw Maria van Casele', in: Ter zilveren bruylofte van den heere Willem Kops en mejuffrouw Maria van Kasele [...]. Haarlem: Wed. Jan Geldorp 1706. [Noord-Hollands Archief, inv. 3235, 2.4.1, no. 44]

'Aan syn doorluchtigste hoogheyd Karel de eerste [...]', 1721, in: Manuscript collection,

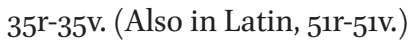

'Nieuwjaarszang, toegezongen aan zyne doorlugtige hoogheid Karel den Eersten [...] 1724.' (In: Koolaart-Hoofman, De naagelaatene gedichten, 87-91.)

'Karelshaven, opgedragen aen haren stigter Karel den Eersten [...] op zyn 7osten verjaeren,den 14 augustus 1724', in: Manuscript collection, 7r-16v. (Dutch prose translation). The Dutch poem printed as: Karelshaven. Toegewyd aan haar stigter Karel,

63 Except for the first four titles (letters by Petronella Harmes-Koolaart, Hoofman's manuscript collection, and Hoofman's collected works in print), these are seperate poems by Hoofman. They are ordered chronologically. For each poem, I first give the reference to the manuscript collection (if the poem was included), then to the contemporary pamphlet publication (if the poem was published), and at the end, between brackets, the reference to the edition by Kops (if the poem was included in his edition). I did not mention the author's name with each title. She signed her poems with her last name "Hoofman" before she got married, and during her marriage with "Koolaart" or "Koolaart-Hoofman". After she was widowed, she signed with "Koolaart-Hoofman" or "Hoofman". 
I. (...) Z.p. 1724. [Landesarchiv NRW, sign. Abteilung Westfalen, 4.4.2. (Sammlungen von Vereinen, Institutionen und Firmen), 4.1, V508-41, Sammlung Ferdinand F.A. Tyrell, 'Gedichte, Leichenpredigte'. ('Lobgedicht auf Landgraf Karl I. von HessenKassel und Karlshafen von Elisabeth Koolaart ndl. 1724').

'Geboortezang aan zyne doorlugtige hoogheid Karel den Eersten [...] Op zynen eenenzeventigsten verjaardag.' [14 augustus 1725] (In: Koolaart-Hoofman, De naagelaatene gedichten, 95-102.)

'Ter intrede van het jaar 1726, aan zyne doorlugtige hoogheid, Karel den Eersten [...].' (In: Koolaart-Hoofman, De naagelaatene gedichten, 103-108.)

'Herderszang op den LXXII. verjaardag van [...] Karel den Eersten [...].' [14 augustus 1726] (In: Koolaart-Hoofman, De naagelaatene gedichten, 109-117; also in Latin, 187-192.)

'Dankzegging aan [...] Karel den Eersten [...] voor een geschenk van zilver, my, voor mynen herderszang, op zynen LXXII. verjaardag gezonden.' (In: Koolaart-Hoofman, De naagelaatene gedichten, 117-119.)

'Algemeene blijdschap op het dubbeld vreugde feest van Karel, I [... ] den 14 van oogstmaand 1727', in: Manuscript collection, 25r-27r. Also printed as: Algemeene Blydschap op het dubbeld vreugde feest van Karel I [...] Z.p., [1727]. [University Library Leiden, sign. PORTEF qu 3:100, PLANO 89 A 3:18.] (Also in Kops' edition: KoolaartHoofman, De naagelaatene gedichten, 129-134.)

'Oud en nieuw Hessen, aan [...] Karel den Eersten [...] op zynen LXXIII. verjaardag.' [1727] (In: Koolaart-Hoofman, De naagelaatene gedichten, 120-128.)

'Op de blijde inkomst tot Kassel van [...] Frederik en Anna Charlotta Amelia [...] den 16 van oogstmaand 1727', in: Manuscript collection, 27v-29v.

Messias, herderszang, aan zyn doorlugtigste hoogheid Karel, I. [...] By de vernieuwing des MDCCXXVIIIsten heiljaars. Print, z.p., [1728]. [University Library Leiden, sign. PORTEF fol 6:32]

Geboortezang aan zyn doorluchtigste hoogheid Karel I [...] Print, z.p., [1728]. [University Library Leiden, sign. PORTEF qu 10:6o, PLANO 89 A 4:30]

'Op de gelukkige herstelling van zijn doorlugtigste Hoogheid Prins Wilhelm [...] uit zijn doodelijke krankheid 1728', in: Manuscript collection, 91r-92v.

Lykzang over zyn doorlugtigste hoogheid Karel, I. [...] Print, z.p., [1730]. [University Library Leiden, sign. PORTEF qu 10:61, PLANO 89 A 4:31]

Aan den allerdoorlugtigsten grootmagtigsten vorst Frederik, $I[. .$.$] Op zyn majesteits blyde$ aankomst in Hessen, 1731. Print, z.p., [1731]. [University Library Leiden, sign. PORTEF fol 6:31] (Also in Kops' edition: Koolaart-Hoofman, De naagelaatene gedichten, 41-48.) 'Ter verjaardag van Mejuffrouw en Nigt Margarita Kraaiestein den 17 van Lentemaand 1734', in: Manuscript collection, 31r-31v.

't Jaargetyde van zyn doorlugtigste hoogheid Wilhelm [...] den XXI. Maart des jaars M DCC XXXIV. Print, z.p. [1734]. [University Library Leiden, sign. PORTEF qu 28:36, PLANO 89 A 2:36] 
'Moederlyke zegen, gezongen by 't Egtelyk verenigen van den Bruidegom Hr. George Harmes, En de bruid Jfr.Petronella Elisabeth Koolaart [...]', in: Hoog- en Nederduitse huwelykszangen voor de heer George Harmes, en juffrouw Petronella Elisabeth Koolaart. [Kassel 1734.] (Also in Kops' edition: Koolaart-Hoofman, De naagelaatene gedichten, 153-156.)

'Op 't jaargetijde van Mejuffrouw en Nigt Maria Kraajestein. Den 2 december des jaars 1734', in: Manuscript collection, 82r-82v.

Op 'tverjaaren van Mejuffrouw en Nichte Margareta Kraayestein den 17. van Lentemaand 1736. Print, z.p. [1736]. [University Library Leiden, sign. PORTEF 32:25]

Geboortezang voor zyn doorluchtigste hoogheid Prins Wilhelm [...], Den 21 Maart des Jaars 1736. Print, z.p. [1736]. [University Library Leiden, sign. PORTEF qu 10:62, PLANO 89 A 4:32]

'Op de blijde inkomste en huldiging tot Grave van Hanau Müntzenberg van zyn doorluchtigste hoogheid Prins Wilhelm [...] op den 25sten April des jaars 1736', in: Manuscript collection, 95r-97v.

\section{Secondary References}

Beer, S. de. 2013. The Poetics of Patronage. Poetry as Self-Sdvancement in Giannantonio Campano. Turnhout: Brepols.

Both, Wolf v. \& Vogel, Hans. 1964. Landgraf Wilhelm VIII. von Hessen-Kassel. Ein Fürst der Rokokozeit. München/Berlin: Deutscher Kunstverlag.

Brewer, J. 1997. 'Authors, publishers and the making of a literary culture', in: The Pleasures of theImagination: English Culture in the Eighteenth Century. New York: Farrar Strouss and Giroux: 125-66.

Geerdink, Nina. 2017. 'The Phenomenon of the of the Married Woman Writer in the Dutch Republic, in Martine van Elk (ed.), Early Modern Women:Lives, Texts, and Objects, online at: https://martinevanelk.wordpress.com/2017/11/o1/the-phenomenonof-the-married-woman-writer-in-the-dutch-republic/ (consulted 26.02.2018)

Geerdink, Nina. 2013. 'De toe-eigening van een triomftocht. Het ontzet van Kopenhagen (1658) in teksten van Vondel, Vos en De Decker', in Lotte Jensen \& Nina Geerdink (eds.), Oorlogsliteratuur in de vroegmoderne tijd. Vorm, identiteit en herinnering. Hilversum: Verloren: $39-51$.

Geerdink, Nina. 2012. Dichters en verdiensten. De sociale verankering van het dichterschap van Jan Vos (1610-1667). Hilversum: Verloren.

Geerdink, Nina. 2010. 'The Appropriation of the Genre of Nuptial Poetry by Katharina Lescailje (1649-1711)', in Anke Gilleir, Alicia C. Montoya \& Suzan van Dijk (eds.), Women Writing Back/Writing Women Back. Leiden/Boston: Brill: 163-200.

Gemert, Lia van. 2010. 'Victim of Distortive Editing. Elisabeth Hoofman, Haarlem 23 February 1664 - Kassel, 4 July 1736', in Gemert, Lia van et al (eds). Women's Writing from the Low Countries 1200-1875. A Bilingual Anthology. Amsterdam: Amsterdam University Press: $344-51$. 
Griffin, Dustin. 1996. Literary Patronage in England 1650-1800. Cambridge/ New York: Cambridge University Press.

Kooijmans, Luuk. 1998. Vriendschap en de kunst van het overleven in de zeventiende en achttiende eeuw. Amsterdam: Bert Bakker.

Lademacher, Horst (ed.). 1995. Oranien-Nassau, Die Niederlände und Das Reich. Münster: Zentrum für Niederlande-Studien.

Oostrum, W.R.D. 2014. 'Hoofman, Elisabeth', in Digitaal Vrouwenlexicon van Nederland, online at: http://resources.huygens.knaw.nl/vrouwenlexicon/lemmata/data/ Hoofman (consulted 12.01.2016)

Pender, Patricia. 2012. Early Modern Women's Writing and the Rhetoric of Modesty. London/New York: Palgrave MacMillan.

Philippi, Hans. 1976. Landgraf Karl von Hessen-Kassel. Ein Deutscher Fürst der Barockzeit. Marburg: N.G. Elwert Verlag.

Pollmann, J.S. 2006. 'Dienst en wederdienst. Patronage en de kunst van het netwerken in het ancien régime', in: Wessels, L. \& Frijhoff, W. (eds.). Veelvormige dynamiek. Europa in het Ancien Régime, 1450-180o. Heerlen/Amsterdam: SUN/OUNL: 213-36.

Prak, Maarten. 2005. The Dutch Republic in the Seventeenth Century. Cambridge: Cambridge University Press.

Prescott, Sarah. 2003. Women, Authorship and Literary Culture, 1690-1740. Houndmills/ New York: Palgrave MacMillan.

Schenkeveld-van der Dussen, Riet. 2010. 'Women's Writing from the Low Countries 1575-1875', in Gemert, Lia van et al (eds). Women's Writing from the Low Countries 1200-1875. A Bilingual Anthology. Amsterdam: Amsterdam University Press: 39-63.

Schenkeveld-van der Dussen, Riet et al (eds). 1997. Met en zonder lauwerkrans. Schrijvende vrouwen uit de vroegmoderne tijd 1550-1850 van Anna Bijns tot Elise van Calcar. Amsterdam: Amsterdam University Press.

Sittig, Claudius. 2012. 'Kassel', in: Adam, Wolfgang \& Westphal, Siegrid (eds.). Handbuch Kultureller Zentren der Frühen Neuzeit I. Berlin/Boston: De Gruyter: 1037-91.

Smith, Helen. 2012. Grossly Material Things. Women and Book Production in Early Modern England. Oxford: Oxford University Press.

Stegeman, Saskia. 1996. Patronage en dienstverlening. Het netwerk van Theodorus Janssonius van Almeloveen (1657-1712) in de Republiek der Letteren. Unpublished Dissertation: Katholieke Universiteit Nijmegen.

Timmers, Katrien. 1994. Uit het loof van Poesij. Elisabeth Koolaart-Hoofman (1664-1736). Unpublished master's thesis Utrecht University.

Werd, G. de (ed.). 1979. Soweit der erdkreis reicht. Johann Moritz von Nassau-Siegen 1604-1679. Kleve: Städtisches Museum Haus Koekkoek. 


\title{
Between Patronage and Professional Writing. The Situation of Eighteenth Century Women of Letters in Venice: The Example of Luisa Bergalli Gozzi
}

\author{
Rotraud von Kulessa
}

\begin{abstract}
In the eighteenth century, Venice was the centre of Italian publishing and culture. Drama writers, such as Carlo Goldoni, were among the first professional writers in eighteenth-century Italy. A large part of the literary field there was dominated by translation and journalism, both of which attracted some prolific women writers, such as Luisa Bergalli Gozzi and Elisabetta Caminer Turra. This chapter will analyse the material implications of the literary production by Luisa Bergalli between patronage and professional writing.
\end{abstract}

Pietro Chiari underlines the material aspects of women writing in eighteenthcentury Italy, in the fictional editorial prefaces of one of his numerous novels ${ }^{1}$ written in the form of fictional memoirs by fictional female authors. ${ }^{2}$ Chiari was a polygraph and wrote for theatre, a field in which he was in competition with Carlo Goldoni and Carlo Gozzi. He also produced about 5 o novels, ${ }^{3}$ which were pre-eminently addressed to a female public in order to promote the principles of Enlightenment. Chiari's positive statements about Italian eighteenthcentury women's writing cannot be taken seriously, but need to be resituated

1 Pietro Chiari, La Francese in Italia o sia Memorie critiche di Madama N.N. scritte da lei medesi$m a$, Venice 1806, 15: "I libraj oggidì non vendono che romanzi, ed io non devo pertanto scrivere che soli romanzi, se scriver voglio de' libri, che sieno venduti, e convertino in oro l'inchiostro dell'angusta miniera a me lasciata in retaggio dalle umane vicende. Scrivete adunque, madama, voi stessa scrivete le memorie della vostra vita, se volete arrichire le stampe d'un libro che vi faccia qualche fortuna."

2 For the romance production of Chiari see Luca Clerici, Il romanzo italiano del Settecento, Venice 1997 .

3 Luca Clerici, Il romanzo italiano del Settecento, Venice 1997, 19ff. 
in the context of the debate about the state of the Italian novel and his quarrel with Carlo Gozzi. ${ }^{4}$ Carlo Gozzi was an enemy of the ideas of Enlightenment and all progressive evolution in the literary field, such as the participation of women. Contrary to this, Chiari often cites the example of French women writers; they were not as numerous in Italy, even thought Italian female readership was significant.

In the context of eighteenth-century Venice, two prolific women of letters were notable: Luisa Bergalli Gozzi and the older Elisabetta Caminer Turra. ${ }^{5}$ Both were also outstanding in critical writing and translation. This chapter will focus on the example of Bergalli, as her literary career follows a transition from patronage to professional writing, in which she tries to obtain a financial benefit from her professional literary work. Furthermore, her case is interesting because of the diversity of her literary activities and her awareness of female literary genealogies.

Luisa Bergalli was born on 16 April 1703 in Venice. Despite her lower-class origins, ${ }^{6}$ her father was an artisan and she received an education complemented by painting lessons from the famous Venetian painter, Rosalba Carriera, along with a foundling relationship with the melodrama writer Apostolo Zeno. ${ }^{7} \mathrm{Her}$ friendship with Rosalba Carriera began a long and productive exchange, ${ }^{8}$ not only an artistic one, but also on the level of consecration in the literary field. Apostolo Zeno became her protector. By initiating her in the dramatic genre of melodrama, ${ }^{9}$ Zeno was responsible for her acceptance as writer of the melodrama Algide for the theatre San Moisé in 1725. Bergalli also wrote a tragedy in 1728 (Teba) and a comedy entitled Le Avventure del Poeta (The Adventures of the Poet) in 1730. Apostolo Zeno might have been responsible for Bergalli's admission to the Academia of Arcadia where she used her Arcadian name,

4 See Rotraud von Kulessa, "Il gioco con l'illuminismo nel contesto veneziano: I romanzi di Pietro Chiari come esempio di polemica e gioco in letteratura", in Conflitti culturali a Venezia dalla prima età moderna ad oggi eds Rotraud von Kulessa et al, Florence 2014, 59-74.

5 Rotraud von Kulessa, "Elisabetta Caminer Turra. Traductrice, médiatrice et 'organisatrice culturelle" , in Femmes écrivains à la croisée des langues 1700-2000 eds Agnese Fidecaro, Henriette Partzsch, Suzan Van Dijk, Genève 2009, 55-66.

6 About the biography of Luisa Bergalli, see Carlotta Egle Tassistro, Luisa Bergalli Gozzi. La vita e l'opera sua nel suo tempo, Rome s.d.

7 Unfortunately, we lack reliable sources about her getting in contact with Zeno.

8 See Catherine M. Sama, "On canvas and on the page. Women shaping Eighteenth Century Italy", in Italy's Eighteenth Century. Gender and Culture in the Age of the Grand Tour eds Paula Findlen, Wendy Wassyung Roworth and Catherine M. Sama, Stanford 2009, 125-50.

9 For the full list of her works, see Adriana Chemello, "Luisa Bergalli letterata di chiara fama", in Luisa Bergalli. Poetessa drammaturga traddutrice critica letteraria. Atti del convegno ed. Adriana Chemello, Mirano/Venice, 2007, 20-22. 
Irminda Partenide. With the publication of her Componimenti Poetici delle Più Illustri Rimatrici di Ogni Secolo (Compositions of the Most Known Women Poets of Every Century) in 1726, Bergalli proved to be especially aware of this particular female literary tradition. ${ }^{10}$ This project was followed by the publication of an edition of the Rime by the Renaissance poet Gaspara Stampa in 1738, which followed the publication of the Rime by Antonio Sforza, her Latin teacher, in 1736. In July 1738, Luisa Bergalli married Gasparo Gozzi, who was ten years her junior. Gozzi came from an old aristocratic Venetian family, which she likely knew through Apostolo Zeno. Her future father-in-law ordered the comedy Le Avventure del Poeta in 1730 and Bergalli contributed to the consecration of the two literary hopes of the family: Carlo and Gasparo Gozzi. ${ }^{11}$ Bergalli was 35 years old when she married and bore five children in the first five years of her marriage. However, after the death of her father-in-law, Iacopo Antonio Gozzi, misfortune befell the Gozzi family: the wealth of the family was squandered and Bergalli's brother-in-law, Carlo Gozzi, the famous antagonist of Carlo Goldoni in his comedic quarrel, accused her of having lost the family's money through her literary activities. ${ }^{12}$ This judgment would, in fact, determine the reception of Bergalli throughout the entire nineteenth century and was revisited only at the beginning of the twentieth century. ${ }^{13}$

The Gozzi couple had to earn money in order to support their large family, and they attempted this through their literary activity. This marriage therefore also marked the shift from patronage to professional writing in the life of Bergalli. Up to this point, the financial reward from their literary activities was dependent on the opinions of patrons. The Gozzi couple's first project was in the direction of the Theater Sant Angelo for one year, between 1747-1748. This failed and was an economic disaster. They also collaborated in a substantial number of translations from French. Bergalli translated Terence from Latin, ${ }^{14}$ Molière ${ }^{15}$ and Racine from

10 See Rotraud von Kulessa, "L'autrice dans l'historiographie littéraire italienne (du 18e siècle jusqu’à l'époque 1900) et l'identité culturelle”, in Pour une histoire genrée des littératures romanes eds Annette Keilhauer/Lieselotte Steinbrügge, Tübingen 2013, 25-36.

11 See Fabio Soldini, "Luisa Bergalli e i Gozzi”, in Luisa Bergalli ed. Adriana Chemello, 36.

12 Carlo Gozzi, Memorie inutili, Bari 1910, vol. 1, 144-45: "Negai l'inaspettata e mostruosa pretesa di crediti della cognata, per quanto sarebbe da' giudici considerato. E perché ella sosteneva d'essere creditrice da noi per essere debitrice a parecchi creditori che avevano a lei affidate merci per i bisogni della famiglia, oblazioni che verificati e liquidati cotesti crediti, sarebbero i creditori risarciti". see also Ibid., 117, 130-32, 134, 143, 148-49, 158.

13 Luisa Bergalli Gozzi, Le avventure del poeta ed. Luisa Ricaldone, Manziana 1997, 9.

14 Le commedie di Terenzio tradotte in verso sciolto (col testo latino al fianco), Venice 1733.

15 Il Misantropo. Commedia tratta da Molière, e messa in versi italiani da Irminda Partenide, Venice 1745 . 
French. ${ }^{16}$ When the French poet Anne-Marie du Boccage came to Venice in 1757, she translated her tragedy Les Amazones, which had been published in a prestigious bilingual edition in $1756 .{ }^{17}$ From 176 o onward, the name of Bergalli became less visible, as she stayed in the shadow of her husband. In fact, many of the attributions of either Gasparo or Bergalli are uncertain. We know that they undertook a translation of Claude Fleury's Histoire Ecclésiastique, a masterpiece in 27 volumes and about 12,000 pages, but only the name of Gasparo Gozzi was credited on the translation. The story of Bergalli is therefore the pursuit of literary fame in order to sustain her husband and save her family from financial ruin, as revealed by her son Francesco. ${ }^{18}$ Her son underlines her efforts to support the material conditions of her large family and investigates her literary activities (such as translation) not particularly honourable, but promising some financial reward.

In order to demonstrate the shift from patronage to professional writing in Bergalli's literary career, I will first look closer at the Venetian literary field of the eighteenth century. Then I will analyse the period of Bergalli as a playwright and especially the case of the comedy Le Avventure del Poeta. Finally, I will focus on the literary activity of the Gozzi couple, which marks the shift to professional writing. ${ }^{19}$

\section{Literary Life in Venice in the Eighteenth Century}

In spite of the political and economic decline of the Serenissima in the eighteenth century, Venice was the centre of European tourism and culture ${ }^{20}$ with a flourishing literary market. ${ }^{21}$ In particular, in the second half of the century, it had the most theatres in all of Europe. ${ }^{22}$ Since the Renaissance, and with

16 Opere di M. Racine, 2 vol., Venice 1736/1737.

17 Le Ammazoni. Tragedia della Signora Du Boccage. Tradotta nell'Italiana favella da Luisa Bergalli Gozzi, Veneziana. E stampato col testo francese, Venice 1756.

18 See Fabio Soldini, "Contributo agli studi su Gasparo Gozzi. Gli inediti 'Frammenti di Memorie' di Francesco Gozzi”, Giornale storico della letteratura italiana, CXLV/450-451 (1968), 369-402.

19 Unfortunately, little information about the economic details of her literary work exists. There are no letters left from her negotiations with editors, etc. Our sources are limited to the letters of Apostolo Zeno, of her husband, the Memorie inutili di carlo Gozzi and the fragments of the memoirs of her son Francesco, presented by Fabio Soldini (op.cit.).

20 Alvise Zorzi, Histoire de Venise, Paris 2000, 440.

21 Mario Infelise, L'editoria veneziana nel '7oo, Milan 1989.

22 Nicola Mangini, I teatri di Venezia, Milan 1974, 91-93; Robert Fajen, Die Verwandlung der Stadt. Venedig ind die Literatur im 18. Jahrhundert, München 2013, 46-48. 
the appearance of the famous publisher Aldo Manuzio, Venice was one of the centres of the European publishing industry. ${ }^{23}$ The economic impact of publishing remained significant for the Republic in the eighteenth century and relative autonomy from the Catholic Church made the practice of censorship comparatively flexible. ${ }^{24}$ Venice, therefore, became the Italian market for the ideas of the Enlightenment, especially in drawing intellectual thought from France. In this context, professional writers were given a chance to invest in popular literary genres, such as the novel. The female public especially appreciated this genre. ${ }^{25}$ It was also in this period that significant translations and adaptations of French literature appeared. ${ }^{26}$

Theatre also featured as the object of translations from French to Italian. At the beginning of the eighteenth century, Italian drama was still dominated by the Commedia dell'arte and the melodrama of Apostolo Zeno. The absence of alternatives gave birth to the famous Goldonian reform of the Italian comedy. Inspired by French comedy of Molière and the new dramatic forms of the comédie larmoyante or the drame bourgeois, Goldoni tried to replace the character improvisation of the Commedia dell'arte by using real characters and the representation of Venetian society of his time. Translations of French drama of the seventeenth and second half of the eighteenth century were hugely popular, especially, of the new French drama genres: the comédie larmoyante or the drame bourgeois. Like Elisabetta Caminer Turra some years later, Bergalli and her husband Gasparo Gozzi were engaged in this field not only to renew the tradition of Italian drama on behalf of the enterprise of translation, ${ }^{27}$ but also to earn money. According to Mario Infelise, in eighteenth-century Venice,

23 Alessandro Marzo Magno, L'alba dei libri. Quando Venezia ha fatto leggere il mondo, Milan 2012.

24 Infelise, L'editoria, 62-65.

25 Maria Rosa Zambon, Bibliographie du roman français en Italie au XVIIIe siècle. Traductions, Paris 1962, VII: “C'est un phénomène complexe sous plus d'un aspect que la vaste influence exercée par la France en Italie au XVIIIe siècle. Dans tous les domaines, les modes françaises ont précédé la véritable influence de la culture. Les femmes qui ont tant de part dans la formation du goût, étaient alors, comme aujourd'hui éprises des modes de Paris que les différentes gazettes, plus ou moins littéraires, célébraient sans cesse."

26 Luigi Ferrari, Le traduzioni italiane del teatro tragico francese nei secoli XVII e XVIII, Paris 1925, XIV: "Nella seconda metà del '70o i traduttori non si contano più. Si traduce da tutte le categorie di scrittori, da uomini di ogni ceto sociale, per pur diletto estetico, per esercitazione stilistica, per ragioni commerciali, per fini pratici di rappresentazione sulle scene, per appagare il generale desiderio di conoscere le opere francesi e di tenersi al corrente di quel repertorio."

27 Rotraud von Kulessa, "Elisabetta Caminer Turra (1751-1796) e L'Europa letteraria: alcune riflessioni sulla traduzione”, Circula: revue d'idéologies linguistiques 1/2 (2015). 
there was no legislation on literary property and authorial rights. However, if a text was requested by an editor and published, but not at the expense of the author - which was often the case - an author could earn about $23-24 \%$ of the profits from the book. ${ }^{28}$ For a book with 3,00o copies, earnings could equate to around 440 Lira and, for a translator of a volume of about 1,00o copies, the profit could be 272 Lira. ${ }^{29}$ According to Infelise, authors such as Gozzi, complained about the difficulties of working with editors. ${ }^{30}$ The most striking example of professional (dramatic) writing is the well-known case of Carlo Goldoni, who was contracted with Girolamo Medebach, impresario of the theatre of Sant Angelo, to write 8 comedies and 2 alternate plays annually for a period of 4 years for 450 Ducati per year. ${ }^{31}$ Goldoni defended the profession of the playwright in the introduction to his metapoetical play Il Teatro Comico $\left(175^{\circ}\right) .{ }^{32}$

\section{Luisa Bergalli as a Drama Author or Self-Reflection about the State of Poet}

The first play that Bergalli published was the melodrama Agide 33 in 1725. Apostolo Zeno - who was her intellectual mentor and had recommended her to some influential personalities of Venetian culture - used a trick to get the play of the young author accepted by the important Venetian theatre, S. Moise. When the theatre called him to write a melodrama, he said that he did not have enough time and sent Bergalli's play instead. He then published a very favourable critique in the Giornale dei Lettori d'Italia. The same Zeno influenced Bergalli's play, along with Racine, an author she translated in 1736/37. In 1723, Apostolo Zeno wrote to the young authoress to praise her melodrama, give advice and correct her manuscript. ${ }^{34}$ One year later, Zeno recommended her

28 Mario Infelise, L'editoria, 189-9o.

29 Mario Infelise, L'editoria, 190-91.

$30 \quad$ Mario Infelise, L'editoria, 191-92.

31 Mario Infelise, L'editoria, 197: "La coraggiosa initiative del Goldoni è ormai indicative dell'esistenza di un nuova tipo d'intellettuale, decisamente sganciato da voncoli di subordinazione nei riguardi di qualche potere e de qualche atristocratico mecenate." It is not possibile to define the exact value of venitian ducati and lira at the time. The annual pay of Vivaldi was said to be about 15 o ducati. The ducato was also named zecchino. Goldoni mentioned the value of earrings about 10 zecchini in his play La bottega del caffè.

32 Cesare de Micheli, Letterati e lettori nel Settecento Veneziano, Florence 1979, 153-201.

33 Paola Serra in L. Ricaldone, Le avventure, 5.

34 Lettere di Apostolo Zeno Cittadino Veneziano, Seconda edizione, vol. 3, Venice 1785, 38991: Alla Signora Bergalli a Venezia: "Alla gentile non meno che valorosa Signora Luisa 
to the Conte Collalto as patron for her playwright and gave her detailed instructions on how to write a dedication..$^{35}$ This letter is also very important in order to understand the genesis of the Componimenti Poetici and the edition of the Rime of Gaspara Stampa. In fact, the Conte Collalto was the descendent of the same Conte Collalto who featured as the object of Stampa's love poetry. Zeno advised Bergalli to mention this fact in the dedication. As I will explore later, this connection to Collalto was important for her career as an editor and compiler. As the edition of Agide demonstrates, Bergalli followed the instruction of her mentor precisely. ${ }^{36}$ Zeno also praised Agide to Andrea Cornaro, descendent of an important Venetian family, and emphasised the superiority of Bergalli's writing in comparison with other playwrights of the

Betgalli, Apostolo Zeno felicità e salute. Vienna 9 ottobre 1723: Ho ricevuto e letto con molta soddisfazione il Dramma intitolato Agide, uscito dal Vostro felicissimo ingegno, di cui avete volute farmi parte a titolo di gentilezza; benchè la vostra modestia voglia farmelo credere a fine di correzione. Esso a dirvi sinceramente l'animo mio, mi è piaciuto sovra quanti ne avete per l'addietro composti; e credo, che sarò per dare lo stesso giudicio a favour di quelli che andrete in avvenire scrivendo, mentre con l'esercizio e con lo studio la vostra poesia si va sempre più ripulendo e perfezionando, a somiglianza dei fiumi reali, che più crescono d'acque nel corso, e più acqistano di limpidezza. Lodovi poi sommamente, che lasciati I soggetti favolosi e comuni, vi siate appligliata agli eroici, I quali più degli altri portano la fantasia e dr cose grandi e sublimi, e dove meglio s'intreccia col nobile l'amoroso. Al genio molle del secolo piaciono sulla scena le passion più delicate; ma spesso ancora se nauseano, quando non le trovin meschiate con le più forti. L'une servono all'altre di condimento, come in ben disposto convito alle dolci vivande le aspre e le amare. Il sviluppo del Dramma è facile e natural; ma lo scolgimento è mirabile, non potendo esser meglio pensato e condotto. Al primo Vostro cenno, e alla prima congiuntura ve ne manderò l'esemplare. A riscontro dei versi vi sarà di quando in quando qualche coserella da me notate, più per farvi cosa grata, dacchè me lo richiedete, che perchè ve ne fosse bisogno. Esso poi è dignissimo della protezione del Sig. Conte Barzizi, cui divotamente reverisco, e insieme della pubblica comparsa sopra qualunque teatro: il che un giorno non può mancar di succedere. Le difficoltà che incontrate, non vi sgomentino. I cominciamenti di ogni impresa sono malagevoli e disastrosi: ma finalmente la malignità cede al merito. Nel mio soggiorno di Praga ho parlato a lungo di voi col Sig. Pallavicini, che non si sazia di onorarvi e lodarvi."

35 Lettere di Apostolo Zeno, vol. 3, 454-58: Alla Sig. Luisa Bergalli a Venezia. Vienna 19. Agosto 1724: "Egli è ormai tempo ch'io risponda alla vostra gentil lettera: il che per la mia già superata indisposizione non feci le due settimane passate. Mi son giunti con essa I vostri due Sonetti, I quali mi sono piacuti grandemente, e subito, scritti così di vostra mano, gli ho spediti a S.E. il Sig. Conte Collalto a Pirnitz, luogo di sua giurisdizione nella Moravia, significandogli nello stesso tempo la prontezza e l'piacere, con cui avevate ricevuto l'onore fattovi da lui nell'accettare la dedicazione della vostra Opera. [...]".

36 Agide, re di Sparta. Dramma per musica di Luisa Bergalli da rappresentarsi nel Teatro Giustiniano di san Moise l'anno 1725, consagrado a sua Eccellenza il Signor Antonio Rambaldo, Conte di Collalto, Venice 1725 . 
time. ${ }^{37}$ In another letter of the same year, Zeno encouraged her to continue her new play, ${ }^{38}$ la Placidia, of which no traces remain, ${ }^{39}$ and another one he entitled Arianna, which might have been L'Elenia (as the play contains a character named Ariana). In October 1725, he carefully critiqued Bergalli's play and promised her he would recommend it to the Princess. ${ }^{40}$ The libretto of L'Elenia was published in 1730, set to music by Tommaso Albinoni, and performed at the Sant Angelo theatre. ${ }^{41}$ It is, in fact, dedicated to the Princess of Palestrina, ${ }^{42}$ with whom Bergalli claims female solidarity. Before L'Elenia, in 1728, her

37 Lettere di Apostolo Zeno, vol 4, 17: Al Sig. Andrea Cornaro a Venezia, Vienna 13. Gennajo 1725: "Vi ringrazio delle novità teatrali. Il Seleuco che si ricita in S. Angelo, è l'Antico fatto in S. Cassano già molti anni da me e dal Pariati. Non è cattiva opera, ma non delle mie migliori, e dà troppo nel melancolico; e quanto a me, non avrei dato agli impressarij consiglio di riporla sul teatro. Ho però caro, che non dispiaccia, e che sostenga il credito del teatro. Ho riletto l'Opera della Bergalli, che sempre più mi è piaciuta. Ella è condotta e scritta assai bene, e fa vergogna a tante puerilità e sciocchezze, che escono alla giornata della penna di cotesti poetastri."

38 Lettere di Apostolo Zeno, vol. 4, 40-41: Alla Sig. Luisa Bergalli a Venezia. Medlin, 26. Maggio 1725 .

39 See also Luisa Ricaldone, "La passion per il teatro di Luisa Bergalli", in Luisa Bergalli, poeta, drammaturga, traduttrive, critica letteraria. Atti del convegno ed. Adriana Chemello, Mirano $2008,47-58,56$.

$40 \quad$ Lettere di Apostolo Zeno, vol. 4, 63-64: Alla Sig. Luisa Bergalli a Venezia. Vienna 13. Ottobre 1725: "Ho ricevuto il Vostro Dramma. L'ho letto e riletto con piacere. E scitto assai bene, e assai bene caratterizzato, e condotto. Si sostiene dal principio al fine ugualmente in tutte le sue parti, e me rallegro con voi. Permettetemi solo che con libertà vi dica il mio sentimento. Temo molto, che nel terzo atto la sua rappresentazione riesca troppo asciutta e melancolica, per essere appunto troppo ripiena di passion e di affetti. Lo stesso finimento lascia disgusto nell'animo degli uditori, I quali avrebbono desiderato di veder contenti I due principali personaggi, Placidia e Costanzo, la cui virtù le rende sin da principio sì interessati nella loro felicità. Non può con ragione darsene a voi biasimo di avere fatto in tal guise, avendo seguitato la vera istoria, che obbliga Placidia alle nozze con Ataulfo, costrettavi dalla necessità di salvar così la sua patria. Ciò fu cagione ch'io alter volte avendo posto l'occhio su tal soggetto, nè trovando rimedio al male, non mi sono rischiato nè di alterarlo, nè di esporlo sopra il teatro: ma presone il midollo, lo applicai ai successi di Fl. Anicio Olibrio, che dal Sig. Patriati e da me unitamente fu verseggiato. Vi do col mio sentimento, non con oggetto di farvi opposizione, ma solo a fine di dirvelo sinceramente, poichè così mi comandate. Ciò nonostante farollo trascrivere in buona maniera; e lo stesso faro dell'Arianna, quando mi giunga: ed io stesso allora, di consenso del Sig. Principe Pio, Cavaliere sopra la Musica, presenterò l'uno e l'altro componimento all'Imperatrice Regnante, alla quale il Vostro ingegno e merito è assai palese, e che desidera di vedere qualche altra cosa di Vostro. Il Sig. Antonio Pellegrini, insigne Pittore, e cognate della Sig. Rosalba, il quale ora è qui [...]."

41 Sama, "On canvas and on the page", 128.

42 L'Elenia. Dramma per musica. Da recitarsi al Teatro di S. Angelo l'anno 1730 dedicata a S.E. Donna Teresa Buoncompagni, Barberini, Principessa di Palestrina, Venice 1730, 3-5: "Voi, o Eccelentissima Principessa, [...] Mi giova però di credere, che non vogliate in questa 
tragedy Teba, inspired by the French tragedy of Racine, was published with a dedication to Marco Miani. ${ }^{43}$ Bergalli did not sign the play and no information exists about its performance on the stage.

Unfortunately, Zeno's correspondence does not provide any information about the material details of Bergalli's relationship with the theatres or the publishers. It does, however, demonstrate the ongoing importance of patronage: the central theme of Bergalli's comedy Le avventure del poeta, which she wrote in $173^{0^{44}}$ as demanded by her future father-in-law Iacopo Antonio Gozzi, to whom the play is also dedicated. In the dedication letter, the author emphasises her devotion to the aristocratic family and underlines on the other hand the autobiographical inspiration of the playwright. ${ }^{45}$ Knowing both her future and the playwright, the dedication acquires an ironical character.

The comedy, which is in five acts and in hendecasyllable (endecasillabo) verse, is in contrast to classic comedy in that it has no love plot. Instead, it details the life of a poor poet, Orazio, who tries to earn money through his poetry in order to feed his sister, Camilla, and his father, Ridolfo. Even if he writes poorly, he must come to terms with the fact that he is not able to earn money with his literary activities as patronage no longer functions. So Camilla, his intelligent and pragmatic sister, earns money for the family by doing needlework. Bergalli doubled her own personality in the two main characters, Orazio and Camilla, and perhaps for reasons of bienséance, she avoided making Camilla a female poet. When the patron, Conte Valerio, comes for the first time to the home of Orazio's family, he suggests Camilla also pursue a literary

occasione dar luogo al Vostro discernimento, in modo, che l'innata vostra gentilezza non abbia campo di sosternermi, e di parlarvi a mio vantaggio. Donna come io sono, giovine, ed inespersta, lontanissima dal pensiero di riscuotere applause, merita certamente da voi compatimento e protezione [...]."

43 Teba. Tragedia dedicata a sua eccellenza il Signor Marco Miani, Venice 1728.

44 Luisa Bergalli, Le avventure del poeta, Commedia, Venezia, Cristoforo Zane, 1730.

45 Le avventure del poeta, ed. Ricaldone, 19: "All'illustrissimo Signor Iacopo Antonio Gozzi Sign. Padron mio Colendiss. Ha per lo appunto un anno, che mi faceste commanda, Illustrissimo Signore, di scrivere una qualche commedia; e cioè che non mi lusingava poter ottenere per forza di mio prorio istinto, mi venne fatto per valore di Vostro cenno. Ella è questa intitolata; delle quali guardando in un certo modo a me stessa d'interno, mi pare talento di scrivere. [...] Dall'altra parte so certo, che s'io ne taccio, pregiudicando insieme al vostro merito, e al mio dovere: così per non donar troppo a me, e per non togliere troppo a voi, parmi bene di accenar solamente una qualche cosa, tra le molte, che sotto slilenzio passer io voglio. Permettetemi dunque, ch'io dica, come di antichissime nobiltà potete vantarsi, così che furono I vostri [...] Quel ddi che più mi console à l'aver a vederela vostra famiglia sempre più che mai stabilita nel suo decoro [...]. Umil. Devot. Obblig. Serva Luisa Bergalli." 
career. ${ }^{46}$ But the situation of her brother has already revealed to her that money is difficult to earn by writing. ${ }^{47}$

The Conte is not only cruel, but also uncultured. The only person who is willing to pay Orazio is the merchant Prospero; his generic name stresses the prosperity of the bourgeois class of eighteenth-century Venice. In the end, Orazio rejects his literary aspirations and accepts the position of professional writer at the court of Lorena. There was no satisfactory ending for the poet in the Venetian context. The only positive element is the Conte's eventual realisation about his behaviour. ${ }^{48}$

With her comedy, Bergalli is not only one of the few authors in the eighteenth century who focuses on the situation of the poet, but she preceeds Carlo Goldoni's comedies in more than one respect: firstly, in the realistic social satire of Venetian society of that time and through the characters of Conte Valerio and his wife Bianca, Bergalli describes the decadent society of eighteenth-century Venice. The couple is arrogant, ignorant and cruel, and they have not yet understood how the system of exchange of work and money functions. They try to reward Orazio with symbolic prizes: admission to the Arcadia Academy, a portrait and other kinds of gifts. Perhaps, here lies an ironic perspective of Bergalli's own situation. Camilla, as the rational member of the family, is the one to complain about this misunderstanding. ${ }^{49}$

In opposition to Camilla, who is able to feign interest to create a positive impression on the Count in order to earn money, ${ }^{50}$ Orazio represents intrinsic motivation, sincerity and virtue. ${ }^{51}$

46 Ibid., 23: "Val. Ritornar, che hanno a fare I complimenti/ Presso di un cavalier, che vuol, che siete/Tutti di casa sua? Ditemi, è forse /Poetessa anch'ella? Rid.Illustrissimo, no:/ Na ben vorri, che anch'ella ormai lasciami/Questi vili esercizj, ed attendere/Agli studij: che certo diverebbe/ Una novella ... una novella ... Val.Saffo/."

47 Ibid., 26: "Cal. Che sia pure maledetta quel'arte dei poeti, /Che bevon sempre al fonte di Elicona,/E non mangiano mai. Povero Orazio,/Ha ben ragione quando si lamenta”.

48 Ibid., 8o: "Val. Signor Orazio, veramente veggo/Il nostro torto, e se adesso dovessi/Ricominciar a favorirvi, il altra/Guisa lo vorrei far".

49 Ibid., 28: "Cam. [...] ma perché I ricchi, I nobili/Non sono tenuti a pagarvi? Or. Perchè, / Come dice Diogene, fa senso/ Agli uomini quell uom solo nel vil/stato cader possono anch'essi sentono/Pietade, ver bi grazia per un cieco, Per uno Storpiato, perché ciechi,/E storpiati devenir potrebbero/Ach'essi: ma con un poeta cosa/hanno a che far? Ti par mai, che letterati/O amanti di virtù divenir possano?"

$50 \quad$ See Pamela D. Stuart, "Eroine della dissimulazione. Il teatro di Luisa Bergalli", Quaderni veneti (19 June 1994), 73-92.

51 Paola Serra in Le avventure del poeta, ed. Ricaldone, 11: "Se Camilla, avvalendosi del buon senso pratico di cui è riccamente investita, è la coscienza lucid ache esprime la contradizzione. Orazio rappresenta invece l'uomo di lettere nei suoi aspetti di idealismo, di 
On the other hand, there is the merchant Prospero, the only character willing to pay for Orazio's sonnets. He represents the values of the new middle class, strangers to the traditions and customs of the old aristocratic class. Prospero knows that work merits payment. A crucial moment in the play occurs in Scene 4, Act III, when the Conte and Prospero - the old and the new world confront one another. While the Conte disapproves Prospero's willingness to pay Orazio and worries about the possible reactions of the Academy of Arcadia, ${ }^{52}$ Prospero defends the material value of poetical work. Ridolfo represents the ancient world through his admiration for aristocracy. His desire to be a part of this world may have been inspired by the Bourgeois Gentilhomme of Molière.

It is to Bergalli's merit that she tried to renew the Italian Comedy before Goldoni. The plot is incomparable with the Commedia dell'Arte and, moreover, Bergalli rejects the use of traditional masks. Her comedy is inspired by a sense of reality and social critique, like Goldoni's was later, in the middle of the century. The subject of her critique is Venetian society, in which her portrayal of aristocratic protagonists compares to the aristocrats of Goldoni's Locandiera, such as the Marchese di Forlipopolo. Like Goldoni after her, Bergalli revalues the role of bourgeois working people. Orazio resembles Pandolfo of La bottega del caffè and Camilla resembles Mirandolina, because of her pragmatism and her ability to pretend. The comedy functions as a kind of self-fullfilling prophesy that previews Bergalli's future life with Gasparo Gozzi.

\section{The Publication of the Componimenti Poetici and the Rime of Gaspara Stampa}

The publication of the Componimenti Poetici delle più Illustri Rimatrici d'Ogni Secolo ${ }^{53}$ must also be seen in the context of Bergalli's relationship to Apostolo Zeno, who was the initiator - as friend of Crescimbeni - of the Arcadian dependence of Venice (L'Accademia degli Animosi). ${ }^{54}$ In 169o, Gian Vicenzo

purezza, talora di ingenuità, ma anche di corretezza morale e di professionalità: una figura inno vativa di intellettuale, caratterizzata da un insieme di virtù non ancora apprezzate socialmente, ma che tendon a fare del letterato un individuo sempre più dignitoso e sempre meno disposto a riconoscere come intrattenitore di una certa classe rappresentativa del potere".

Le avventure del poeta, ed. Ricaldone, 55: "Indietro il vostro ducato, uom da bene;/Ed imparate a conoscere cosa/sia trattar co' poeti di tal sorta./El non ci manderebbe altro, che gli Arcadi/ sapesse questa ...". 
Gravina and Giovanni Mario Crescimbeni founded the Accademia dell' Arcadia in Rome, from the Accedemia Reale of Christina from Sweden, in order to fight against the bad taste of baroque poetry and to defend the tradition of petrarchism. In 1726, the Accademia dell' Arcadia already had over 40 colonies all over Italy, including the Colonia degli Animosi in Venice. In contrast to the Renaissance academies, the Arcadia accepted women as members and became an important stronghold for female literary activity. ${ }^{55}$ It was customary to publish anthologies of the members of Arcadia and it is not so astonishing that the project of the Componimenti was also guided by Apostolo Zeno. ${ }^{56}$ The Componimenti of Bergalli, in the tradition of the anthologies of Domenichi ${ }^{57}$ and Recanati (1716), was published in two volumes by Antonio Mora: the first, containing 112 women poets of the past and, the second, containing approximately 136 women poets from 1575 up to those still living. The list of the second volume was completed by Zeno and, in a cited letter, he recommends that she also read Crescembeni's Comments. ${ }^{58}$ Zeno also mentions that she should be patient with the second volume and only publish the first. But Bergalli ignored

55 See Tatiana Crivelli, "L'Arcadia femminile: spazi reali e simbolici di un'interazione culturale", Höfe-Salons-Akademien. Kulturtransfer und Gender im Europa der Frühen Neuzeit, eds Gesa Stedmann, Margarete Zimmermann, Hildesheim/Zürich 2007, 241-54.

56 Lettere di Apostolo Zeno, vol. 4, 123-26: Alla Sig. Luisa Bergalli a Venezia. Vienna 20 Luglio 1726: "Ho ricevuto con la vostra gentil letter ail catalogo delle rimatrici, delle quali porrete I componimenti nella vostra raccolta. Ho osservato che ve ne mancano parecchie, d'alcune delle quali a piè di questa troverete segnato il nome. Presso di me non hoc he pochissimi libri di poesie italiane, avendoli tutti lasciati press oil Sig. Andrea mio fratello. Il P. mio fratello, come più pratico, potrà farveli vedere, acciocchè ne facciate buon uso. Egli è bene, che diate un occhiata all'Istoria, e ai Commentarj del Crescembeni, nei cui volume ne troverete nominate moltissime, che non avete osservate, ed egli vi dirà I libri, ne' quali I componimenti s'incontrano, e s'io gli avrò, avrete modo di ricopiarli. Veggo che avete fretta di dar fuori la vostra raccolta, per non perder l'occasione della dedicatoria al Sig. Cardinale Ottoboni. Ma queste sono cose da potersi fare all'infretta, e su due piedi, come suol dirsi: ma han di bisogno di mature esame, e di lunga diligenza e fatica. Pure se non potete fare altrimenti, date fuori quello che avete raccolto, col titolo di I. Volume, riservandovi a darne la continuazione in altri. Così vi torrete di dosso l'accusa di aver tralasciato, e avrete modo di averne da alter parti. Circa le notizie, poche ne sfuggiranno a voi e al fratello, delle quali io possa servirvi. Lo faro tuttavolta, qualora ne sia da voi dimandato. Saluto tutti di vostra casa, e le Sigg. Carriere; lo stesso fa a voi il Sig. Conte di Collalto che loda molto il Vostro disegno, e vi raccomanda la sua M. Gasparina, della quale è stato fatto tanto onore alla sua casa nella persona del Conte Collaltino da lei amato, [...]."

57 Lodovico Domenichi, Rime diverse d'alcune nobilissime e virtuosissime donne, Lucca 1559; Giovanni Battista Recanati, Poesie italiane di Rimatrici viventi raccolte da Teleste Ciparissiano, Venice 1716 .

58 Giovan Mario Crescimbeni, Commentari intorno alla sua Istoria della volgar poesia (1702). 
the suggestions of her mentor; according to Adriana Chemello, the editor did not accept this solution because they received permission to stamp quickly.59

The anthology was dedicated to Cardinal Pietro Ottoboni, a Venetian protector of the Arts. In her preface to the readers, Bergalli notes two reasons for her work: firstly, she wants to reinstate women's poetry and, secondly, she also expects some honour for her own person. She accompanies the preface with a long citation from Moderata Fontes epic poem Floridoro (1581), in which the Renaissance poet underlines the equality of men and women in the field of literature. Bergalli also refers to the long tradition of women writing of the Serenissima. At the end of her preface, she thanks all those who provided her access to libraries and gave help and advice, such as Giacomo Soranzo, Antonio Sforza, her latin teacher, and Apostolo Zeno. Interestingly, at the end of his letter, Zeno also recommends the second edition of Gaspara Stampa's Rime ${ }^{60}$ published after the death of Stampa - which was published at the request of the Conte Collalto, one of the important patrons of Bergalli. Her act of remembering women's literary productions must be seen within the context of the Arcadian patronage system, which favoured the high consciousness of female authorship by Bergalli. Furthermore, with the publishing of the Almanacco delle donne ${ }^{61}$ (a very popular genre which usually had a great number of readers), the participation of Bergalli cannot be proved by any source other than Tiziana Plebani. The editor of the modern edition of the Almanacco ${ }^{62}$ argued that Bergalli might have contributed to the volume. ${ }^{63}$ In any case, it would have been a nice opportunity for her to earn some money by reusing the Componimenti for a large audience.

\section{The Literary Activity of the Gozzi Couple or How to Earn Money by Writing}

Luisa Bergalli was married to Gasparo Gozzi on 8 July 1738. As mentioned in the introduction, the family's financial situation was poor during this period and Gasparo was not able to resolve the debts of their already large family,

59 Adriana Chemello, "Le ricerche erudite di Luisa Bergalli", in Geografie e genealogie letterari. Erudite, biografe, croniste, narratrici, épistolières, utopiste tra Settecento e Ottocento eds Adriana Chemello, Luisa Ricaldone, Padua 2000, 49-88, 55 .

6o Rime di madonna Gaspara Stampa, con alcune altre di Collaltino, e di Vinciguerra conte di Collalto, e di Baldassare Stampa, Venice 1738.

61 Almanacco sacro e profano per l'anno santo 1750 in difesa delle donne, Venice $175^{\circ}$.

62 Almanacco delle donne, ed. Tiziana Plebani, Venice 1991.

63 Adriana Chemello, Le ricerche, 81. 
to which the couple added another five members. During the first six years of their marriage, ${ }^{64}$ Bergalli, presumably absorbed by the consecutive birth of her five children, published only one tragedy in $1743 .{ }^{65}$ The first collaborative literary project of the couple, conducted in order to earn money, was the translation of Fleury's monumental Histoire ecclésiastique, mentioned by Gozzi in his correspondence. ${ }^{66}$ The project was assigned to Bergalli, but it was Gozzi who handled transactions with the editor. He was also preoccupied with the progress of this monumental project (27 volumes with over 12,00o pages), which was published in 1766 only under the name of Gasparo Gozzi. Bergalli translated the first volume, due to her consecutive pregnancies Gozzi had to help her with the remaining volumes. In a letter, Gozzi admits that she was the better translator, but that he was pleased to see the work attributed to him. The genesis of this project reveals the real conditions of married women and literary activity in eighteenth-century Venice. Once married, women of the ancien régime often did the work for publications attributed to her husbands. Another example is that of the German translator Luise Adelgunde Gottsched. ${ }^{67}$

The second project the couple started in order to earn money was the direction of the theatre Sant'Angelo in Venice in 1747/48. If the assertions of Carlo Gozzi in his Memories ${ }^{68}$ and fragments of the memoirs of his son Francesco are

64 See also Fabio Soldini, "Luisi Bergalli e I Gozzi", in Luisa Bergalli, poeta, drammaturga, traduttrive, critica letteraria. Atti del convegno ed. Adriana Chemello, Mirano 2008, 33-46.

65 Elettra. Tragedia da rappresentarsi nel teatro Grimani di S. Samuele, Venice 1743.

66 Gasparo Gozzi, Lettere, ed. Fabio Soldini, Parma 1999, Lettera 30 Ad Anton Federigo Seghezzi, Visinale 22 dicembre 1740, 63-64: "Vi ringrazio con tutto l'animo degli avvertimenti intorno alla Traduzione [Storia ecclesiastica del Fleury, RvK]. Certamente la vogliono con tanta velocità, che sarà cagione di qualche scandalo. E quell'Antipater ve ne dia prova, che perdio non può essere per altro, che per troppa furia. Non per iscusar me, ma per dire la verità a voi, dicovi che ho gran maraviglia, che quella traduzione sia creduta mia, perché il Mozzati sa bene d'averla data a mia moglie, non a me; e non so come il Pecori [il stampatore veneziano Carlo Pecora; RvK] creda altrimenti. Anzi avendo io detto, che non mi sentiva da poter prendere quella faccenda sulle spalle, e ch'io lo pregava dar la versione a mia moglie, egli se ne contenta, e il libro lo diede a lei, come a più veloce, e più continua nell'opera; e così ella scrisse il primo tomo. Ma nel secondo vedendo che la si uccideva sotto la fatica, e non poteva [p. 64] nella prestezza continuare la fretta dello stampatore, ho incominciato a soccorrere anch'io qualche ora del dì. Tutte queste cose vi dico sotto il seggello della fede; [...]"

67 Rotraud von Kulessa, "La traduction allemande de Cénie de Françoise de Grafigny", in $L a$ traduction des genres non romanesques au XVIIIe siècle, eds Annie Cointre/Annie Rivara, Metz 2003, 315-28.

68 Carlo Gozzi, Memorie inutili, 148: "[...] fui avvertito che la moglie di mio fratelleo, sempre progettante poetica e sempre vaga di maneggi e d'amministrare, aveva sedotto il povero mio fratello, facendogli credere e vedere mentalmente delle montagne d'utilità a firmare la scrittura della condotta del teatro di Sant' Angelo in Venezia, e non so quante scritture di 
to be trusted, ${ }^{69}$ Bergalli initiated the project. Francesco described the situation of the family in these years in the following words: "There were ensuing divisions in our family. But before they could be arbitrated, my father had to think about his literary studies and my mother translated from Latin and French in order to maintain fourteen persons". ${ }^{70}$ The family was so much in debt that they had to to leave the Palace of San Cassiano to the merchant Francesco Zini, and move to a modest apartment in San Giacopo dell'Orio. With these conditions, it is unsurprising that Bergalli's project did not succeed. She tried to save money by casting cheap actors, which partly contributed to the failure of the project. Two of the first actresses were unable to satisfy the public at the first performance, and Francesco noted a riot amongst the spectators. The company also tried its chance on the Terreaferma and turned back to Venice where the performance of Gasparo Gozzi's Esope was a modest success. The plays performed were translations from French of Boursault and Destouches, and another, $\mathrm{La}$ Bradamante, with an uncertain attribution to Bergalli. ${ }^{71}$ The Gozzi couple attempted to reform Italian theatre as Elisabetta Caminer Turra did later with her translations from French drame bourgeois. ${ }^{72}$ Nevertheless, the theatre project could not be saved. Bergalli was even forced to reduce expenses for the orchestra lighting and, according to Francesco, replaced oil with fat-burning lamps, to the protests of the audience. In the end, Gozzi had to pay the actors, along with the two first actresses, by ensuring their house as a life annuity.

After this disastrous experience, Francesco described a calmer period in which the couple tried again to earn through translations. ${ }^{73}$ One of their last

stipendio ad una truppa di comici, che dovevano agire ad una rovina, ma ch'ella conteggiava per un opulente vantaggio, facendosi impresario, direttrice e sovrastante e seguace alla truppa ne' teatri dei Venezia e di terraferma. Avrei voluto non avere questa notizia. Benché ella desse un'idea delle anteriori direzioni tenute e mi servisse di giustificazione, non ebbi alcun sentiment allegro, e compiansi il fratello e gl'innocenti suoi figli. Tentai, senz'essere nominato di far dissuadere quella femmina rovente sopra una tale impresa. Ributtò ogni persuasion tentata, certissima d guadagnar de' tesori da far mordere le dita d'invidia a' di lei cognati ..."

69 Soldini, "Contributo".

70 Soldini, "Contributo", 374, note 1. "Ne sguirono le divisioni in famiglia. Ma prima che queste si concludessero, toccò a mio padre di dover pensare col suo letterario studio, e a mia madre che traduceva dal francese e latino, a dare mantenimento a quatordici persone [...]"

71 See Soldini, “Contributo", 376, note.

72 Rotraud von Kulessa, "Elisabetta Caminer Turra. Traductrice, médiatrice et 'organisatrice culturelle', in Femmes écrivains à la croisée des langues 1700-2000, eds Agnese Fidecaro, Henriette Partzsch and Suzan van Dijk, Genève 2009, 55-66.

73 Soldini, "Contributo", 384 : "Raccolta in questa casa la dispersa famiglia, pareva che le cose avessero preso una qualche piega di buon Sistema e che tutti stesero al sordo. Traduceava per vadagno mia madre dal francese, così faceva mio padre." 
chances to profit from translation was on the occasion of the visit of French poet Anne-Marie du Boccage to Venice in 1757. Bergalli translated her tragedy Les Amazones, which was published with portraits of the two authors in a prestigious bilingual edition in $1756 .{ }^{74} \mathrm{Up}$ until $176 \mathrm{o}$, she published only occasional poetry and an anthology of female poets dedicated to Caterina Dolfina Tron, ${ }^{75}$ who was a protector of the Gozzi's. ${ }^{76}$ After her death in 1779, her son Francesco complained that all the rights of the literary productions of his mother were in the hands of an editor, which left him without his inheritance. ${ }^{77}$

\section{Conclusion}

Eighteenth-century Venice is often considered the birthplace of professional writing due to its flourishing publishing industry, numerous theatres and the work of Carlo Goldoni. However, according to Mario Infelise, Goldoni was an exceptional new type of intellectual who was able to work more or less independently from patronage. ${ }^{78}$ The case of Luisa Bergalli Gozzi is revealing: it shows, in an emblematic way, the difficulties of the shift from patronage - as a system that no longer functioned in a rising bourgeois society - to professional writing in the middle of the century, as demonstrated in Bergalli's play $L e$ Avventure del Poeta. The Gozzi couple belongs to a group of authors who attempted to live from their writing, but never really succeeded. ${ }^{79}$ Furthermore, Bergalli is a striking example of a woman still active in the literary field, and privy to its difficulties, once married.

74 Le Ammazoni.

75 Rime di donne illustri a su aeccelenza Caterina Dolfina cavaliera e procuratessa Tron nel gloriosissimo ingresso alla dignità di procuratore per merito di San Marco di sua eccelenza cavaliere Andrea Tron, Venice 1773.

76 Soldini, "Contributo", 395.

77 Soldini, "Contributo", 397: "Prima di morire e della sua agonia, alla presenza di due testimony, con una carta da lei sottoscritta mi lasciò erede tutte le sue azioni e ragioni. Non parlo della sua eredità, degli effetti mobile di sua ragione a me rimasti, perché un zero formerebbe il valore di quelli. Mi ha spiaciuto moltissimo l'aver ella in vita passate le sue opera letterarie a certo stampotore che non potei mai rinvenire, e così non ho ne pur pottuto essere erede delle sue composizioni: questo é per lo più il fine degli uomini letterati e delle persone di merito."

78 Mario Infelise, L'editoria, 198.

79 Mario Infelise, L'editoria, 194: “[...] ma sempre di più nella seconda metà del Settecento furono coloro che cercarono di trasformare l'attività intellettuale in un mestiere come tutti gli altri. Erano spesso laici, [...] ed arano borghesi o esponenti della piccolo nobiltà, privy di rendite cospicue. In tal senso Gasparo Gozzi è una figuara emblematica. Anch'egli tra 
The patronage system is still relevant for the most prolific period of Bergalli's literary career, the time in which she had a well-known male mentor, Apostolo Zeno, who recommended her to some influential patrons and theatres. Once married, she worked less as an autonomous writer and financial negotiations seem to have been carried out by her husband. Gradually, Bergalli lived in the shadow of her husband and material sorrows about the debts of their large family became more significant than the pursuit of literary fame. The case of Bergalli is a tragic one; she was excluded from literary history and the history of translation, while her husband received relative literary fame. Her life may disappoint the modern reader, but it likely reflects the real condition of women's writing in the first part of the eighteenth century. She was certainly not alone; similar cases include Elisabetta Caminer Turra, who was also witness to the trials and tribulations of Venetian women attempting to succeed in this field, ${ }^{80}$ and avoid an ambiguous position so as to receive symbolic or economic capital. ${ }^{81}$ As the example of Luisa Bergalli Gozzi shows, it was more difficult for a woman to be accepted as a writer and to earn money from literary activities. Exposed to the unfounded accusations of her brother-in-law, Carlo Gozzi (known for his misogynistic attitude), she refused recognition and limited her literary activities to anonymous translations.

\section{Bibliography}

\section{Primary References}

Bergalli, Luisa. 175o. Almanacco sacro e profano per l'anno santo 1750 in difesa delle don$n e$, Venice: Modesta Fenzo.

Bergalli, Luisa. 1991. Almanacco sacro e profano per l'anno santo $175^{\circ}$ in difesa delle don$n e$ (ed. Tiziana Plebani). Venice: Ippocampo Editrice.

Bergalli Gozzi, Luisa. 1725. Agide, re di Sparta. Dramma per musica di Luisa Bergalli da rappresentarsi nel Teatro Giustiniano di san Moise l'anno 1725, consagrado a sua Eccellenza il Signor Antonio Rambaldo, Conte di Collalto. Venice: Marino Rosselli.

gli anni Quaranta e Cinquanta tentò di mantenersi soprattutto scivendo. [...] ma gli non ebbe fortuna. Le retribuzioni dei librai non gli consentirono di eviatre molti umiliazioni e le inizitive di vario genere che intraprese non sempre andarono a buon fine."

80 Rotraud von Kulessa, "Elisabettea Caminer Turra".

81 Rotraud von Kulessa, Entre la reconnaissance et l'exclusion. La position de l'autrice dans le champ littéraire en France et en Italie à l'Epoque 19oo, Paris 2011. 
Bergalli Gozzi, Luisa. 1728. Tragedia dedicata a sua eccellenza il Signor Marco Miani. Venice: Cristoforo Zano.

Bergalli Gozzi, Luisa. 1726. Componimenti poetici delle più illustri Rimatrici d'ogni secolo. Venice: Antonio Mora. Available on http://artflx.uchicago.edu/cgi-bin/philologic/ navigate.pl?iww.7 (consulted 26.o3.2014).

Bergalli Gozzi, Luisa.173oa. Le avventure del poeta, Commedia. Venice: Cristoforo Zane. Bergalli Gozzi, Luisa. 173ob. L'Elenia. Dramma per musica. Da recitarsi al Teatro di S. Angelo l'anno 173odedicata a S.E. Donna Teresa Buoncompagni, Barberini, Principessa di Palestrina. Venice: AlviseValvasense.

Bergalli Gozzi, Luisa. 1733. Le commedie di Terenzio tradotte in verso sciolto (col testo latino al fianco). Venice: Cristoforo Zane.

Bergalli Gozzi, Luisa. 1736/37. Opere di M. Racine, 2 vols. Venice: Domenico Lovisa.

Bergalli Gozzi, Luisa. 1738. Rime di madonna Gaspara Stampa, con alcune altre di Collaltino, e di Vinciguerra contoi do Collalto, e di Baldassare Stampa. Venice Francesco Piacentini.

Bergalli Gozzi, Luisa. 1743. Elettra. Tragedia da rappresentarsi nel teatro Grimani di S. Samuele. Venice: Simone Occhi.

Bergalli Gozzi, Luisa. 1745. Il Misantropo. Commedia tratta da Molière, emessa in versi italiani da IrmindaPartenide. Venice: Giambattista Pasquali.

Bergalli Gozzi, Luisa. 1756. Le Ammazoni. Tragedia della Signora Du Boccage. Tradotta nell'Italiana favella da Luisa Bergalli Gozzi, Veneziana. E stampato col testo francese. Venice: Pietro Bassaglia.

Bergalli Gozzi, Luisa. 1997. Le avventure del poeta (ed. Luisa Ricaldone). Manziana:Vecchiarelli.

Bergalli Gozzi, Luisa. 1773. Rime di donne illustri a su aeccelenza Caterina Dolfina cavaliera e procuratessa Tron nel gloriosissimo ingresso alla dignità di procuratore per merito di San Marco di sua eccelenzacavaliere Andrea Tron. Venice: Valvasense.

Chiari, Pietro. 1806. La Francese in Italia o sia Memorie critiche di Madama N.N. scritte da lei medesima. Venice: Antonio Rosa.

Crescimbeni, Giovan Mario. 1702. Commentari intorno alla sua Istoria della volgar poesia. s.l. s.n.

Domenichi, Lodovici. 1559. Rime diverse d'alcune nobilissime e virtuosissime donne. Lucca: Busdraghi.

Gozzi, Carlo. 1910. Memorie inutili. Bari: Laterza.

Gozzi, Gasparo. 1999. Lettere (ed. Fabio Soldini). Parma: Ugo Guanda Editore.

Recanati, Giovanni Battista. 1716. Poesie italiane di Rimatrici viventi raccolte da Teleste Ciparissiano. Venice: Sebastiani Coleti.

Zeno, Apostolo. 1785. Lettere di Apostolo Zeno Cittadino Veneziano, Seconda edizione. Venice: Franco Sansoni. 


\section{Secondary References}

Chemello, Adriana. 200o. 'Le ricerche erudite di Luisa Bergalli' in Chemello, Adriana and Luisa Ricaldone, (eds) Geografie e genealogie letterari. Erudite, biografe, croniste, narratrici, épistolières, utopiste tra Settecento e Ottocento. Padua: Il Poligrafo: $49-88$.

Chemello, Adriana. 2007. 'Luisa Bergalli letterata di chiara fama' in Chemello, Adriana (ed.) Luisa Bergalli. Poetessa drammaturga traddutrice critica letteraria. Atti del convegn. Mirano/Venice: Eidos: 20-22.

Clerici, Luca. 1997. Il romanzo italiano del Settecento. Venice: Marsilio.

Crivelli, Tatiana. 2007. 'L'Arcadia femminile: spazi reali e simbolici di un'interazione culturale' in Stedmann, Gesa, and Margarete Zimmermann (eds) Höfe-SalonsAkademien. Kulturtransfer und Gender im Europa der Frühen Neuzeit. Hildesheim/ Zürich: Olms: 241-54.

Egle Tassistro, Carlotta. [s.d.] Luisa Bergalli Gozzi. La vita e l'opera sua nel suo rempo. Rome: Tipografia Nazionale.

Fajen, Robert. 2013. Die Verwandlung der Stadt. Venedig ind die Literatur im 18. Jahrhundert. München: Wilhelm Fink.

Ferrari, Luigi. 1925. Le traduzioni italiane del teatro tragico francese nei secoli XVII e XVIII. Paris: Champion.

Infelise, Mario. 1989. L'editoria veneziana nel '7oo. Milan: Franco Andeli.

Kulessa, Rotraud von. 20og. 'Elisabetta Caminer Turra. Traductrice, médiatrice et 'organisatrice culturelle" in Fidecaro, Agnese et. al. (eds) Femmes écrivains à la croisée des langues 1700-2000. Genève: MétisPresses: 55-66.

Kulessa, Rotraud von. 2013. 'L'autrice dans l'historiographie littéraire italienne (du 18e siècle jusqu'à l'époque 19oo) et l'identité culturelle' in Keilhauer, Annette and Lieselotte Steinbrügge (eds) Pour une histoire genrée des littératures romanes. Tübingen: Narr (Editions Lendemains 32): 25-36.

Kulessa, Rotraud von. 2014. 'Il gioco con l'illuminismo nel contesto veneziano: I romanzi di Pietro Chiari come esempio di polemica e gioco in letteratura' in Kulessa, Rotraud von et. al. (eds) Conflitti culturali a Venezi dalla prima età moderna ad ogg. Florence: Franco Cesati: $59-74$.

Kulessa, Rotraud von. 2015. 'Elisabetta Caminer Turra (1751-1796) e L'Europa letteraria: alcune riflessioni sulla traduzione' in Circula: revue d'idéologies linguistiques $1-2$.

Mangini, Nicola. 1974. I teatri di Venezia. Milan: Mursia.

Micheli, Cesare de. 1979. Letterati e lettori nel Settecento Veneziano. Florence: Olschki.

Sama, Catherine M. 20o9. 'On canvas and on the page. Women shaping Eighteenth Century Italy' in Paula Findlen, Paula, Wendy Wassyung Roworth and Catherine M. Sama (eds) Italy's Eighteenth Century. Gender and Culture in the Age of the Grand Tour. Stanford: University Press: $125^{-5}$. 
Soldini, Fabio. 1968. 'Contributo agli studi su Gasparo Gozzi. Gli inediti 'Frammenti di Memorie' di Francesco Gozzi' in Giornale storico della letteratura italiana $\operatorname{CXLV}\left(45^{\circ}-451\right): 369-402$.

Soldini, Fabio. 2007. 'Luisa Bergalli e i Gozzi' in Chemello (2007): 33-46.

Stuart, Pamela D. 1994. 'Eroine della dissimulazione. Il teatro di Luisa Bergalli' in Quaderni veneti 19 June: $73-92$.

Zambon, Maria Rosa. 1962. Bibliographie du roman français en Italie au XVIIIe siècle. Traductions. Paris: Sansoni.

Zorzi, Alvise. 200o. Histoire de Venise. Paris: Payot. 


\title{
From Queen's Librarian to Voice of the Neapolitan Republic: Eleonora de Fonseca Pimentel
}

\author{
Irene Zanini-Cordi
}

\begin{abstract}
A poetess, translator and journalist, Eleonora de Fonseca Pimentel was born in $175^{2}$ in Rome into a liberal family. ${ }^{1}$ When her family moved to Naples, she thrived in the Arcadic circles of a city favourable to learned women. Pimentel started her career as a court poet, and then became the Queen's librarian. Following a tragic marriage and separation from her husband, she requested a state pension and translated from the Portuguese two books on economy and law, which supported specific political stances of the King. In 1798, she was accused of Jacobinism, imprisoned and deprived of her librarian post and pension. Her journalistic activity culminated in her becoming director and editor of the Monitore Napoletano (1799), the paper of the short-lived Republic, before being publicly hanged in August 1799. This chapter addresses the course of Pimentel's writings in relation to her economic situation. It shows that her literary production evolved according to the development of her political thought, which, in turn, mirrored her economic status.

Forsan et haec olim meminisse juvabit

Perhaps, one day, even this will be good to remember VIRgIL, Aeneid, I, 203
\end{abstract}

According to Vincenzo Cuoco, these are the last words that Pimentel pronounced on 20 August 1799, before stepping onto the scaffold in Napoli's Piazza Mercato. They are the words that Aeneas uses to console his surviving troops after they are shipwrecked on the shores of Carthage. It is only natural

1 For readability purposes I will refer to Eleonora de Fonseca Pimentel as Pimentel. 
to assume that Pimentel was directly referring to the events that led to the declaration of the Neapolitan Republic on 22 January 1799 and the fierce persecution of the patriots in June of the same year led by the inept Ferdinand IV, King of the Two Sicilies, and his vengeful spouse Maria Carolina.

In hindsight, we can appreciate the prophetic irony of Pimentel's wish as the royals did everything in their power to erase any memory of the Neapolitan Revolution, which started with the destruction of all personal documents and portraits pertaining to its most prominent proponents. This reactionary move was very successful in obliterating facts, names and images from the popular conscience, and achieved its goal also by controlling the mechanisms of private and collective memory. ${ }^{2}$ Not only was Pimentel denied the nobility's privilege of being decapitated instead of hanged, but her body was also left on the gallows for some time instead of being immediately taken down. Finally, and because of a sudden rainstorm, it was buried quickly in an unmarked grave in a nearby churchyard, now inexistent. ${ }^{3}$

Only after Italian unification was it safe to let memories of that period emerge. In 1899, on the centenary of the Neapolitan Republic's birth, a group of scholars led by the philosopher Benedetto Croce collaborated to assemble an Albo stori$c o$ : a volume intended to reconstruct this historical period so instrumental to the birth of the Italian Risorgimento. It was Croce who brought Pimentel back to history; he even wrote one of his first monographs on her. In his portrait of her, he sketches the figure of a new intellectual, a typical product of the Neapolitan Revolution, a person who contributed her literary skills and philosophical beliefs to a committed political activism that ultimately claimed her life. However, if Croce was instrumental in recovering the figure of Pimentel the patriot, with the weight of his authority he managed to consign to oblivion, once again, a relevant part of her identity by denying her literary production any originality. 4

2 A. Orefice, La penna e la spada, Napoli 2009, 38.

3 Orefice's suggestive thesis is that Pimentel's body was secretly exhumed in 1845 together with her uncle's and cousin's, and buried in the Fonseca's family chapel in the cemetery of Poggioreale. There, next to the cell of a certain Antonio Fonseca (1859-1897) there is that of his supposed wife Eleonora, of which no other record can be found. In the above courtyard, an angel belonging to the sculptural group La Religione (1845) by Tito Angelini, would be pointing underground exactly towards the Fonseca's chapel and Eleonora's burial site.

4 "Eleonora de Fonseca Pimentel cannot be placed among the original thinkers and researchers who deserve a place in the history of a particular science or discipline. But we find this noble character of a woman always in first line in the intellectual and political battles of her time: in her vigorous mind is reflected the best culture of the time, and in her gentle soul it acquired warmth of feeling and energy of will" ("Eleonora de Fonseca Pimentel non può annoverarsi tra i pensatori e ricercatori originali cui spetta un posto nella storia di speciale 
In fact, he dismissed her poetry as "courtesan content in Metastasio-like form". ${ }^{5}$

It is well known that Croce strongly disliked Metastasio's poetry and that he did not nurture any sympathy for the Arcadia, to which Pimentel belonged. One has to wonder why it is only recently, with Elena Urgnani's La vicenda letteraria e politica di Eleonora de Fonseca Pimentel (1998), that we finally have a complete reconstruction and fair evaluation of this outstanding woman's literary production. ${ }^{6}$ It is undeniable that the paucity of extant official documents has played a role in preventing an accurate reconstruction of her figure; however, it is worth noting that as a woman, she crossed many lines and shattered social boundaries. The courtly environment of eighteenth-century Naples (at least for a while) seemed to encourage the visibility of women on the cultural scene, but the nineteenth-century political and cultural reaction stifled it. It is only with the recent developments of Italian feminist thought, and the desire to retrace a female genealogy through the recovery of figures of the past, that Pimentel has been restored to history despite all the contradictions that make her a representative of the later currents of Italian Enlightenment and a forerunner of Pre-Romanticism.

Recently discovered papers related to Pimentel's separation trial, which include her own testimony, were housed in the civil court and escaped the cleansing fury of the Restoration. These papers have allowed us to recover the personal history of this woman. The documents present a multifaceted picture of life as an abused wife and unfulfilled mother, which enhances our understanding of Pimentel as a member of the Arcadia, admirer and follower of Metastasio, court poet, Queen's librarian, translator, political activist and, finally, as journalist and director of the 35 numbers of the Monitore Napoletano (1799), the main newspaper of the Neapolitan Republic.

Urgnani has rightly pointed to the many similar experiences shared by $\mathrm{Pi}-$ mentel and Ugo Foscolo, both of them representing transitional figures of the intellectual movement towards modernity; writers who strive to find a meaningful role in civil society. Absorbing and interiorising the peculiar idealism and drive to social justice that characterised the so called Triennio giacobino

scienza o disciplina. Ma noi troviamo questa nobile tempra di donna sempre in prima linea nelle battaglie intellettuali e politiche dei suoi tempi: nella mente vigorosa di lei si rifletteva la migliore cultura allora viva, e nel suo animo gentile acquistava calore di sentimento ed energia di volontà"). B. Croce, La Rivoluzione Napoletana del 1799, Bari 1926, 4.

5 "Contenuto cortigiano in forma metastasiana". B. Croce, "Eleonora de Fonseca Pimentel", in Rassegna degli interessi femminili, Roma 1887, 42.

6 Elena Urgnani, La vicenda letteraria e politica di Eleonora de Fonseca Pimentel, Napoli 1998. 
(1796-1799), they both directed their writers' skills to political activism, which ultimately claimed Pimentel's life and condemned Foscolo to exile. Their journalistic activity was similar (Foscolo directed the Monitore Italiano from 1788 until 1789 and one can safely assume that Pimentel was aware of it while directing her Monitore Napoletano). Both also felt the need, with their translation activity, to open up the stale horizon of the Italian cultural debate to the more dynamic, European one. ${ }^{7}$

There is, however, at least one more trait that these two writers share as transitional figures of intellectuals shifting from the ancient regime into modernity: the power of economic imperatives. In Italian literature, the role played by the economic factor in this transformation of the intellectual - from court poet to politically engaged patriot - has yet to be given due analysis. It is a particularly difficult topic to address when considering women writers. In the eighteenth-century Italian world of letters, being a writer, translator or journalist was hardly considered a profession for women, let alone a reputable one. Publicity in any form, even connected to the printed word, was dangerous for a woman's modesty, especially if she was unmarried. Notably, the few exceptions are concentrated in the more cosmopolitan and culturally dynamic Venetian Republic. There, Luisa Bergalli Gozzi helped support her family by writing and publishing poems, plays, translations and even, at one point, by trying her luck as a theatre impresario. (See the chapter by Von Kulessa in this volume.) In spite of, and actually because of, these enterprising activities, her brother-in-law, the writer Carlo Gozzi, defamed her and ruined her reputation for posterity. One generation later, the teenager Elisabetta Caminer Turra, a contemporary of Pimentel, received her training as a journalist and translator in the Venetian workshop of her father, Domenico Caminer, who founded and directed L'Europa Letteraria and the Giornale Enciclopedico. However, her book reviews and epistolary correspondence with Italian and European intellectuals attracted fiery attacks on her reputation. They subsided only when she married the physician Antonio Turra, who allowed her to pursue her literary interests. She became the director of the journal Europa Letteraria and, once she moved to the mainland with her husband, she opened a publishing house in Vicenza: the Stamperia Turra. Unfortunately, she died poor, devastated by breast cancer, ostracised by the provincial community, assailed by creditors, and begging friends to help her get subscribers for her journal.

7 E. Urgnani, "L'opera letteraria di Eleonora de Fonseca Pimentel", Rivista di letteratura italiana, XV (1997), 290. 
What are the economic dynamics at play for an eighteenth-century woman who considers her writing a profession, a cultural and social mission, not just a personal, albeit educational, pastime? What influence does the economic factor have on her career and life in general? Assuming the validity of the assertion "the personal is political", and since the political almost always entails economics, one can posit also the validity of the statement "the personal is politics and economics". The destiny of an eighteenth-century Italian woman was still mostly a matter of politics and economics. How did economic issues drive and shape Pimentel's life, and her intellectual and political trajectory? How did her literary talent serve her material needs?

In the previously mentioned study, Benedetto Croce wondered:

How is it, that this woman, who still in 1790 appears to be a supporter of the rights of the prince and an encomiast of King Ferdinand, and rewarded and awarded a pension at court for her work on the chinea, few years later transforms herself into a fiery Jacobin who conspires against the State and plays no small part in the revolution of $1799^{8}$

According to Croce, the answer to this question is to be found in the intensifying of the Bourbons' anti-revolutionary fanaticism motivated by the consequences of the French Revolution. This reactionary attitude clashed with the progressive ideals of the Neapolitan noble intellectuals who had been influenced by Jacobin ideals. Faced with an authoritative state and excluded from the government, the nobles rebelled. This is certainly a compelling explanation. However, I would add that in Pimentel's case the personal and economic vicissitudes she underwent were instrumental in making her understand the Neapolitan people in a more pragmatic way. I will argue that her literary production evolved according to the development of her political thought, which, in turn, mirrored her daily life experiences. At first, her ideas and poetic efforts were closely connected to the court's intellectual environment. They reflected both her formative milieu and her economic dependency on the court, with the legitimacy she derived from it. Later, however, when her social idealism became active political commitment, she faced poverty, while the strength of her journalistic production stemmed from the freedom granted by the power of ideals.

8 "Come mai questa donna, che ancora, nel 1790, appare sostenitrice dei diritti del principe ed encomiatrice del re Ferdinando, e premiata e pensionata a corte per la sua opera sulla chinea, qualche anno dopo, si cangia in un'ardente giacobina, che ordisce congiure contro lo Stato ed ha parte non piccola nella rivoluzione del 1799?" (Croce, La Rivoluzione, 22.) [All Italian texts are translated into English by me, Izc.] 


\section{Literary Beginnings: The Salons, the Arcadia and the Court}

The family of Pimentel's mother, Doña Caterina López de León, was from Lisbon and its male members, mostly lawyers, had ties with the Holy See. They were also very loyal to the King of Portugal who had rewarded Doña Caterina's father by bestowing on the daughter an annual pension. This pension, passed onto her by her mother, would determine Pimentel's destiny. Her father, Don Clemente Henríquez de Fonseca Pimentel Chaves, was a registered member of the nobility in Portugal. Doña Caterina and Don Clemente married in Rome in 1750, and Eleonora was born in 1752. Don Clemente's brother had also married one of Doña Caterina's sisters. In 176o, apparently in relation to the expulsion of the Jesuits from Portugal, the abbot Don Antonio López, one of Doña Caterina's brothers, moved the two López families to Naples. ${ }^{9}$

In Naples, thanks to Don Antonio's cultural network and his friendship with Josè de Sà Pereira, consul of Portugal, the young Pimentel had ready access to the best teachers in town and, later on, to the most popular literary salons that were also renowned abroad. ${ }^{10}$ In these gatherings, la portoghesina ("the little Portuguese") - fluent in Portuguese, Italian, French, English, Latin and Greek was famous for reciting elegant poems of her own composition. At the age of sixteen, she was admitted to the Neapolitan Accademia dei Filateti ("friends of truth") with the cumbersome name of Epolnifenora Olcesamante, an anagram of her forename and surname. Politically, the accademici supported the idea of social and human progress promoted by an enlightened monarchy. Thinkers, such as Pietro Giannone and Antonio Genovesi, left a strong imprint on Neapolitan intellectuals' thought, a drive to move away from Rome's political influence and to guide the sovereign in a politics of innovative social reforms. ${ }^{11}$

On 12 May 1768, on the occasion of the marriage of Ferdinand IV to Maria Carolina of Austria, Pimentel presented Il Tempio della Gloria (The Temple of Glory) at court. In this long and ambitious epithalamion, the encomiastic intention was accompanied, if not obscured, by a show of poetic skills and erudition. Sergio Minichini has noted that the collective expression of joy on the part of relatives, friends and courtiers, which is usually at the heart of such

$9 \quad$ F. Schiattarella, La Marchesa giacobina, Napoli 1973, 11.

10 Of particular importance was the literary salon of D. Francesco Vargas Maciucca, which was furnished with a beautiful library. Among the intellectuals who frequented it there were Filangieri and the brothers Domenico and Giuseppe Cirillo (future martyrs of the Neapolitan Republic). Pimentel was also introduced to the salon of Eleonora Fusco where, according to Croce, many intellectuals belonging to the Neapolitan nobility gathered.

11 Schiattarella, La Marchesa, 18-19. 
a composition, here only takes up the first four stanzas out of a total of 79 octaves. This would confirm, in his opinion, that the object of the composition was to obtain the personal benevolence of the royals and, more generally, it was an attempt to inspire enlightened reforms and to celebrate social progress. ${ }^{12}$ The poetess displays her erudition by reconstructing in detail the Bourbons' and Hapsburgs' genealogy and, where history fails, she employs myth to cast a heroic and divine aura on the royals.

This first work, however, also seems to aim at asserting the role of the female poet. It presents the realm of Venus as a locus amoenus where nature is moralised and the protagonist has to choose between "lovely girl" ("amabile Donzella") and "serious woman" ("Donna grave"), reflecting the dichotomy between pleasure and commitment to reality. At the heart of the poem, decorated with the simplicity of light and surrounded by the dynasties of the Hapsburg and the Bourbon, the Temple of Glory shines as the site of examples of virtue. It stands in contrast to the splendour of precious gems and metals of Venus' abode where the goddess is lost in an amorous embrace with Mars. If it is true that this juxtaposition between Athena and Venus, intellect and love/ heroism and pleasure, is part of Metastasio's vocabulary, it is also possible to read it as the desire of the woman poet to be considered on par with her male colleagues, to be taken seriously in her role of intellectual and to be viewed as a "Donna grave", not simply an "amabile donzella". 13

Despite its inevitable stylistic and compositional awkwardness (the poetess was only 16 years old!), this encomiastic epic poem reached its goal of granting its author greater visibility. It introduced Pimentel to the Queen and, quite probably, obtained her an invitation to join the Arcadia. In fact, she was inducted into the Arcadia that same year as Altidora Esperetusa, a name she used to sign her future compositions, but which does not appear on the frontispiece of Il Tempio della Gloria. ${ }^{14}$ This work was probably instrumental in initiating her correspondence with Metastasio (1770-1776), which thrived through the mediation of Giuseppe de Souza, the secretary to de Sà Pereira in Naples, who was later transferred to the Portuguese embassy in Vienna. The poetess' correspondence with the old imperial court poet was educational but, as we shall see, caused her some trouble.

\footnotetext{
12 S. Minichini, “Il Tempio della Gloria (1768)", in Eleonora Fonseca Pimentel. Una donna tra le muse ed. R. Giglio, Napoli 1999, 27.

13 Ibid., 29.

14 The Neapolitan colony of the Arcadia had become, under the leadership of the abbot Antonio Jerocades, a masonic lodge.
} 
The sonnet was one of the first poetic genres with which Pimentel experimented. Its malleable form allowed her the use of different registers, from the encomiastic and mythological to the more personal and realistic tone. She often experimented with language, even using, on a couple of occasions, the Neapolitan dialect. The first extant sonnet appeared in a 1770 collection printed in Naples for the occasion of the Carafa wedding. As Urgnani points out, it is noteworthy that this sonnet "The Goddess who Reigns in Pafo and Amantuta" (La Dea, ch'in Pafo, e in Amantuta Impera [= Venus, IZc]), appeared together with the literary homages of prominent Neapolitan intellectuals among which there is a composition by Mariangela Ardinghelli, a well-known woman of sciences and a translator. This could signal that Pimentel's society recognised the public intellectual role of women of letters and women of science. ${ }^{15}$ Clear proof that Pimentel had achieved fame outside Naples and, indeed, was considered among the most prominent Italian women writers, was the inclusion of her sonnet "Pretty Nightingale, Who with Sweet Notes" (Vago Usignol, che ne' Soave Accenti) in the 1773 volume, Rime di donne illustri a S. E. Caterina Dolfina cavaliera e procuratessa Tron (Poems of Illustrious Women to HE Caterina Dolfina Tron), edited by Luisa Bergalli Gozzi to celebrate her patroness' new role as first lady of the Serenissima. ${ }^{16}$ This work is relevant in Italian literature since through extensive archival research, and relying on the help of a network of scholars from all over Italy, Bergalli Gozzi managed to assemble an exhaustive volume of poetry representative of all the known Italian women poets from the Renaissance to the present. For the first time in Italian literature, a woman editor reconstructed an Italian literary female genealogy. Pimentel's presence inserts her firmly in a female poetical tradition. Her sonnet establishes a further relationship of 'sisterhood' with the dedicatee, Caterina Dolfin, a poetess and fellow Arcadian, by addressing the experience of pain at the loss of a parent that both women shared. ${ }^{17}$ Signing the sonnet with her Arcadian name, Altidora Esperetusa, Pimentel addresses Caterina Dolfin Tron in her role of poetess ("Vago usignol") mourning her father, and draws a parallel between their experiences. She closes the composition in quite an

\footnotetext{
15 Urgnani, La vicenda, 83.

16 L. Bergalli Gozzi, Rime di donne illustri a S.E. Caterina Dolfina cavaliera e procuratessa Tron, nel gloriosissimo ingresso alla dignità di procuratore per merito di S. Marco di S.E. il Cavaliere Andrea Tron, Venezia 1773, 34.

17 A very well educated and cultured woman, Caterina Dolfin was admitted into the Arcadia in 1757 with the name of Dorina Nonacrina. Her poetry dealt mostly with personal experience and grief for the death of her beloved father. After she managed to get her first marriage annulled, she married Andrea Tron thus becoming the most powerful woman in Venice and a patron of writers and artists.
} 
unexpected way by admitting her inability to focus on celebrating Caterina Dolfin Tron in her poem as she is overwhelmed by grief for the death of her own mother. ${ }^{18}$

Another sonnet from 1773 is addressed to a woman, Queen Maria Carolina, but it displays excessive subservience, especially for modern sensibility, by embracing the current patriarchal ideology. "It Will Come, Royal Woman, It Is Prescribed in the Sky" ("Verrà, Donna Real, è in Ciel prescritto"), is an attempt to comfort the Queen who, by birthing a second daughter instead of the desired male heir, had 'failed' in her official role and missed another chance to preside over the meetings of the State Council. This poem, which should be celebrating life, is instead postponing the celebration for the day of the "great delivery" ("gran parto"), because the two "Dawns" ("Aurore" [= daughters, IZC]) cannot but be its messengers, like dawn precedes the day.

Indeed, only two years later, in 1775 , Pimentel had the opportunity to celebrate the "gran parto". She saluted the birth of Charles, the heir to the throne, with the cantata "The Birth of Orpheus" (La Nascita di Orfeo), a work that assured her the prestigious position of Queen's librarian. Although Eleonora at this point in her life did not need a job, her encomiastic efforts finally paid off. She had acquired an official position at court that sanctioned her image in society as a woman of letters. Moreover, from a more political perspective, there was no better way of influencing the Queen's politics towards the prized social reformism desired by her circle of enlightened friends than by being in charge of the Queen's books.

This projection of idealistic hopes for the betterment of society through the power of the ruling class is evident in "La nascita d'Orfeo". A cantata is a musical form derived from the madrigal. Highly popular at court and in salon gatherings, it blended the vocal and instrumental, the recitative and the melodic. In general, Pimentel's cantatas, because of their formal complexity and high number of characters, strongly resemble miniature melodrammi: Metastasio mastered both forms. ${ }^{19}$ The son of Ferdinand IV and Maria Carolina is here hailed as Orpheus, the son of the god Apollo and the muse Calliope, destined to bring peace and to have a positive influence on society. This enlightened role for the prince is clearly explained in the Argomento where the poetess portrays

18 A sonnet dealing in a more conventional way with the theme of death was an epicedium published in a 1771 volume commemorating the death of Giovanni Capece, Bishop of Oria. "Allor, che sciolto da' mortali affanni" is certainly a more traditional poetic tribute although the poetess experiments by borrowing imagery and language from Dante. 
Orpheus as "founder of societies and maker of laws" ("fondatore di società e facitore di leggi") and, following his example,

The prince Charles of Bourbon, [...], perfecting the work of Orpheus, and finishing what his elders have wisely begun, will correct the abuses of society and will lift it to the highest, imperturbable, state of happiness and perfection. ${ }^{20}$

The dialogue between Pallas and Venus, who gifts the prince with wisdom and grace respectively, lays out the importance of the social contract by voicing two major drives within civil society: the necessity to see "the advantage of common life" ("il vantaggio della vita commune [sic]", Pallas, vv. 140-141) and the awareness that the functioning of society is not only based on need, but is inspired by reciprocal love (Venus). In Pimentel's open and unabashed praise of the royals, one can recognise - as Croce did - the general attitude of the intellectuals of the time who, like Voltaire with Catherine of Russia, simply perceived it as a way to promote the well-being of the peoples and to encourage a civilising effort - an attitude, which - at that moment - the King and Queen of Naples seemed to embrace. ${ }^{21}$

\section{An Unhappy Marriage and Economic Troubles}

Pimentel's life took a harsh turn in 1771. Her mother, terminally ill, decided to leave to her nineteen-year old "most dear, most loved and most esteemed daughter D. Eleonora” ("carissima, dilettissima e stimatissima figlia D. Eleonora") all her possessions. However, the inheritance was intended as a dowry, and would return to the family if she did not marry, died without children, or became a nun. Included in the inheritance was the already mentioned annual pension granted by the King. Finding a husband for Pimentel was the next step, and her maternal grandmother thought well of keeping the money in the family by arranging an engagement with her cousin Michele López, a lawyer. She went so far as to leave them all of her own possessions. The two cousins

20 "Il principe Carlo Borbone, [...], perfezionando l'opera di Orfeo, e traendo a fine ciò che hanno i suoi maggiori saviamente incominciato, correggerà gli abusi della società e la innalzerà all'ultimo imperturbabile stato di felicità e di perfezione". (E. de Fonseca Pimentel, La nascita di Orfeo, Napoli 1775.)

21 M. Porcelli, "La poesia di Eleonora de Fonseca Pimentel", in Eleonora de Fonseca Pimentel tra mito e storia ed. F. d'Episcopo, Napoli 2008, 38 . 
had grown up together and, apparently, had similar ambitious and independent personalities. However, when Michele López was sent to Malta in 1776 to obtain the "Royal Military Order of Malta" ("Sovrano Militare Ordine di Malta") to add to his family's prestige, he stopped correspondence with his fiancée. After writing many letters that went unanswered, the spurned Pimentel wrote one, which included a biting sonnet to Michele in which she bids him to choose between Malta and herself.

The engagement failed, but Pimentel's father found - what he thought was a good substitute in don Pasquale Tria de Solis, a subaltern in the royal army and twenty years her senior. The premises of an unhappy marriage could be predicted in the profound cultural differences between these two families: the Tria de Solis family was wealthy but prone to debt, religiously conservative and part of the military circles, while the De Fonseca family supported the Kingdom of Naples's independence from the Pope and mingled with the Enlightened and reformist intellectuals.

In the testimony for the separation trial, it is Pimentel's own voice that reconstructs for us her life as a married woman. It clearly spells out the psychological and physical abuse to which she was subjected, and the economic pressure she experienced. Once she moved into her husband's home, she had to deal with three unmarried, bigoted and cruel sisters-in-law. They disapproved of her literary activity and condemned her correspondence with other intellectuals as immoral conduct. Her husband refused to give her the stipulated monthly sum for her own personal expenses from the beginning, to the point that she had to buy a volume of Petrarch's poems and another of Guidi's with money from a small lottery win. With another lottery win, she subscribed to the volumes of the Encyclopédie. Her husband also harassed her for money to pay his own debts. To settle his debts she had to sell her jewelry and borrow money against her dowry. Her request for necessary items, such as a new dress for public functions, was met with firm refusal, to the point that she had to complain to her father and borrow from her brother. Most disconcerting is the narrative of how - because of her husband's violence - she lost her baby, and almost her own life, five months into her pregnancy:

One evening, not finding a volume on music of the translation of English Universal history, which I had borrowed, I addressed him saying that if the book were not to be found he should have had the diligence to look for it in some bookstand, to which one of his sisters answered angrily and he went on getting out of the bed where he was and, having taken me by my waist, threatened to throw me out of a nearby balcony; this sudden violent outburst produced in me such surprise, indignation and fear that 
I fainted, but not wishing to make it public nor to make a fuss at that moment I did not call a doctor; consequently I aborted a dead fetus and was in extreme danger of losing my life, saved almost miraculously by the skills of M. Pean's son. ${ }^{22}$

In her narrative, Pimentel ties this incident directly into the economic question. Not only was the husband incensed at the idea of having to buy a book for his wife, but he also refused, for a long time, to pay the Queen's surgeon who had taken care of her. This miscarriage inspired her to compose an elegiac ode, a striking work and definitely her most original poetical composition, in which scientific knowledge of the time and a pre-Romantic sensibility are the vehicles of her dramatic autobiographical experience. ${ }^{23}$ After this tragic event, Pimentel's books - her metonymic extension - became the primary target of the husbands' fury. He denied her access to them as well as to her circle of cultured friends. He even destroyed them since they undermined his total control of her:

[...] When I went back into my room I found the few books that were there all strewn on the floor, and the following day he came to the crazy decision to want to burn two little books of English letters containing the history of that island, and other books of nice French letters printed in Holland (both unknown languages to him), having argued from the language and from the publication place that they had to be heretical, maintaining that in his role of husband he could and wanted to control my actions and my conscience. ${ }^{24}$

22 “[...] non trovando una sera un tomo legato alla musica della traduzione della storia Universale inglese, statomi imprestato, mi rivolsi a lui dicendogli, che se il libro non si trovava, bisognava che egli usasse la diligenza di cercarlo in qualche bancarozza, al quale mio detto, rispondendo indisponente una delle sorelle, continuò egli alzandosi da sopra il letto dov'era, e presami all'improvviso per la vita, minacciò di gettarmi da un balcone vicino, il quale inaspettato eccesso produsse in me tanta sorpresa, indignazione e spavento che io ebbi a svenire, pur non volendo pubblicarlo né produrre rumore in quell'ora trascurai di chiamare professore alcuno; onde ne venne poi che io sconciassi d'estinto feto, e ne fossi in estremo pericolo della vita, quasi miracolosamente salvata dalla perizia di M. Pean il figlio". (Archivio di Stato di Napoli, fondo Gran Corte della Vicaria, ordinamento Zeni, fascio 133, fascicolo 43, 77-89. In Orefice, La penna, 61.)

23 "Ode elegiaca di Altidora Esperetusa per un aborto, nel quale fu maestrevolmente assistita da M.R Pean il figlio", in Sonetti di Altidora Esperetusa in morte del suo unico figlio, 1779, reprint by B. Croce, Napoli 1900.

24 " $[. .$.$] nel rientrare in camera ritrovai i pochi libri che vi erano tutti sparsi per terra, ed$ il giorno seguente giunse al pazzo furore di voler bruciare due libretti di epistole inglesi contenenti la storia di quellisola, ed altri di belle lettere francesi stampate in Olanda 
The abuse escalates to the point that:

[...] In a situation where I was abandoned by almost everybody, the sisters had ease in oppressing me with actions and lies, and I was meanwhile prevented from freely commiserating with anybody, each step of mine was spied and each one of my writings or letters was read and intercepted..$^{25}$

Finding herself pregnant again, Pimentel asks Gen. Acton, the minister of war, to intervene by reprimanding her husband. Thanks to the help of de Souza, the secretary to the Portuguese ambassador, the sisters-in-law were sent to a monastery after a second miscarriage. Her "failure" to produce a male heir in turn brought her dowry into the Tria de Solis household worsening the family dynamics. Pimentel's husband brought his lover, a low-life "hatmaker" ("cuffiara"), and her young daughter, into the house. To remedy the enormous debts that her husband had contracted, especially with his own brother, Pimentel tried to legally prevent the seizure of all his belongings but was nonetheless forced to downsize the household and to move to a cheaper abode outside town, in a poor area. There, isolated from her relatives and friends, she was forced by her husband to depend on the services of his lover, and even to share her bed with this woman. Once informed about the shady past of her husband's lover, Pimentel managed to oust the woman and her daughter from the house. However, her husband openly continued his liaison and stopped providing for her:

[...] He did not talk to me anymore, he did not provide for daily food. I had to borrow on my word some money from friends, whom I have not paid back yet, and he even kept me for some days without anything. ${ }^{26}$

Finally, through her powerful friends, Pimentel obtained the King's intervention. His letter banned the husband's lover from the Neapolitan State and

(lingue ambe a lui ignote), sia avuto argomento della lingua, e dal luogo che dovessero essere ereticali, affermando che egli come marito poteva e voleva comandare le mie azioni e la mia coscienza". (E. de Fonseca Pimentel, "Separation trial testimony", in Orefice, $L a$ penna, 62.)

25 “[... ] rimessa io quasi abbandonata da tutti s'aprì insieme vasto campo alle sorelle d'opprimermi e coi fatti e con le calunnie, ed intanto veniva a me impedito il libero sfogo con chiunque, spiato ogni mio passo, e letto e intercettato qualunque mio scritto o biglietto". (Ibid.)

26 "[... piú meco non parlava, non provvedeva al giornaliero vitto. Perciocché dovetti io sulla propria parola incomodare di qualche somma gli amici, che non ho ancora soddisfatti, ed alcuni giorni, perfino senza cosa alcuna, mi mantenne". (Ibid., 68.) 
ordered Tria de Solis to cease abusing his wife. In 1784, her father, worried by the man's psychological and physical violence, instead intervened himself and brought his daughter back home. ${ }^{27}$ The separation trial was long and painful as Tria de Solis had kept his word when he declared that,

[...] He would have found all the means and ways to have his whore declared honest and innocent and, on the contrary, his wife a whore, accusing her of long-standing loves and connections that she had with men of letters. ${ }^{28}$

Indeed, a large number of letters from her intellectual friends, such as Metastasio and Alberto Fortis, had been intercepted by the sisters-in-law and turned up as proof of her wifely misconduct during the trial. (It did not help, for example, that in one of these letters Fortis thanked her for mending his linens.) With her father's sudden death in 1785 , Pimentel was deprived of the main emotional and psychological support in her battle against her husband. However, quite inexplicably, Tria de Solis decided to let the lawsuit drop and allowed Pimentel to move in with her maternal uncles.

During her marriage, Pimentel continued composing encomiastic poems, most of them extolling the reforming actions of the royals and celebrating their accomplishments. In the sonnet dedicated to Queen Maria Carolina for the inauguration of the Accademia (of Sciences and Letters, 5 May 1780), the poetess personifies wisdom, Sophia, and makes her travel the Orient finally to find her permanent residence in Naples, at the Accademia. According to an eyewitness, Pimentel was one of seven poets who recited their sonnets in the presence of both royals and she outperformed by far the other six, all priests. ${ }^{29}$ In February 1782, the heir to the Russian throne, Pavel Petrovich, and his wife Maria Fyodorovna, were travelling across Europe under cover as "The Count and Countess of

27 Her personal possessions, when she returned home, amounted to "Two trunks filled with undergarments and dresses for her own use, a poplar cabinet, a bookshelf with books that have been recognised as her own, two silver covers, a copper basin, two blankets - one of ermine, the other of crimson damask - a mattress and six pillows" ("due bauli pieni di biancheria e vesti per suo uso, uno stipone di pioppo, una scanzia con libri che si è detto esser propri di D. Eleonora, due posate di argento, un lavamano di rame, due coverte - una di armesino, l'altra di damasco cremisi - un materasso e sei cuscini"). In Archivio di Stato di Napoli, Processo di separazione, verbale di consegna, allegato. Cited in Schiattarella, La Marchesa, 61 .

28 " [...] avrebbe procurato tutti i mezzi e le vie per fare dichiarare onesta e innocente la sua puttana, e, all'incontro, puttana la moglie, con l'insinuazione di antichi amori e aderenze che essa teneva con uomini di lettere". (Ibid., 62.)

B. Croce, Curiosità storiche, Napoli 1921, 191. 
the North" and arrived in Naples. In all the courts they visited, their arrival was celebrated by festivities and marked by literary homages. For the event, Pimentel prepared a cantata, La Gioia d'Italia (The Joy of Italy), where she celebrated the grand-duke Paolo as son of Catherine the Empress of Russia, "new Pallas" ("Pallade novella"), venerated by intellectuals as an enlightened woman and, as indicated by the poetess, a potential model for Maria Carolina. ${ }^{30}$ Pimentel took advantage of this event to align herself with the likes of Voltaire in extolling the empress. The sonnet "The Genius of Empires" (Il Genio degl'Imperi) was published as an appendix to this cantata and was directly dedicated to the Russian empress. She is defined as "august and strong" ("augusta e forte") and endowed with "bellicose brilliance" ("bellicoso ingegno"), qualities that attract the "Genio degl'Imperi" to shower success on her since she governs "a more stable government" ("più stabil regno") which underscores her political talent.

\section{Economic Dependency on the Court}

If the end of the separation process brought Pimentel a much-needed peace, the death of her father left her in a precarious economic condition. She was forced to beg the King for help, maintaining that the monthly alimony check her husband had been ordered to pay her was insufficient, but that it was also highly unrealistic that she would receive it as he had too many creditors to satisfy. In August 1785, she was granted a small pension of 12 monthly ducats in light of her situation and poetic talent and, later on, she could count on a total of 28 monthly ducats that allowed her to maintain a dignified lifestyle. ${ }^{31}$ According to scholars, the cantata Il Vero Omaggio (The Real Homage), which

\footnotetext{
30 La gioia d'Italia. Cantata per l'arrivo in Napoli delle LL. AA. RR. Il Gran Duca e la Gran Duchessa delle Russie, Napoli 1782.

31 "Informato il Re dello stato infelice in cui si trova D.a Eleonora de Fonseca Pimentel, moglie del cap.no graduato di Sannio D. Pasquale Tria de Solis, da cui vive divisa, e volendo provvedere al sostentamento di tal Donna, la quale è ben degna della Sovrana Clemenza: non solamente in grazia dell'accennata infelicità, ma ancora de' suoi non ordinari talenti, che sono superiori alla sfera del suo sesso, comanda che alla detta D.a Eleonora si somministrino ducati dodici mensuali [...]". (The King having been informed of the unhappy situation encountered by D.a Eleonora de Fonseca Pimentel, wife of the decorated captain of Sannio D. Pasquale Tria de Solis, from whom she lives separated, and wishing to help support such Woman who is well deserving of his Highness' Clemency: not only because of her abovementioned unhappiness, but also because of her unordinary talents, which are superior to the sphere of her sex, he orders that she be given twelve ducats monthly). In Archivio di Stato di Napoli, Ministero Finanze, fasc. 972. Quoted in Schiattarella, La Marchesa, 94.
} 
is not dated but celebrates the return of the royals to Naples after a four-month stay in Sicily in 1785 (April 30-September 7), should be read as a token of gratitude on Pimentel's part for the pension she had just been granted. ${ }^{32}$ This cantata stages the presence of a number of local mythological figures and marine deities waiting for the arrival of the royals on the Bay of Naples while Sebeto (a river near Naples) and Partenope (ancient name for Naples) extoll the royals and compare them to the parents of the nation. On the frontispiece of the work, right below the author's name, appears an epigraph from Oratius's Carmina referring to the return of August to Rome: "as soon as your face appears in splendour to the people, the day passes more pleasing". ${ }^{33}$

The influence of the sovereign on his people, and his constructive interaction with them for the progress of humankind is a theme that will be developed even further in Pimentel's works. For example, her two sonnets celebrating the official inauguration of San Leucio in 1789 focus on the important role of the King in promoting civilisation. ${ }^{34}$ Ferdinand IV had set up a phalansterylike silk and brocade manufactory on the hill of San Leucio where 214 workers, of both sexes, toiled and lived together "In perfect equality of dressing, and absolute prohibition of luxury and communion of property". ${ }^{35}$ While in both sonnets Ferdinand IV is praised for the new laws he imposes on this community, one explicitly portrays him not only as the creator of an ideal society, but also as the reformer of society as a whole.

The newly found freedom from conjugal vexation and economic worries allowed Pimentel to focus completely on what she loved most, her studies, and to have a social life. During the second half of the eighteenth century, Naples was an important destination for Grand Tourists, artists and intellectuals. The Queen's librarian met, among other visitors, the archeologist Munter, the

32 Il vero omaggio. Cantata per celebrare il fausto ritorno delle loro maestà, Napoli 1785 . In Urgnani, La vicenda letteraria, 182.

33 “...vultus ubi tuus affulsit populo, gratior it dies", Orat., Carm., IV, 5, vv. 6-7.

34 In Componimenti poetici per le Leggi date alla nuova Popolazione di Santo Leucio da Ferdinando IV re delle Sicilie, Napoli 1789. This officially sponsored collection of tributes by the most illustrious intellectuals of the time is 240 pages long. It should be noted that Urgnani cites as her source for the two sonnets the abovementioned collection, preserved in the Biblioteca Nazionale di Napoli (140-D-28/2). However, D. De Liso in the chapter "Sonetti (1770-1798)" in Una donna tra le muse, ed. Giglio, claims that this collection only contains one sonnet, while Urgnani had probably consulted a different source, a miscellaneous collection preserved in the Società Napoletana di Storia Patria.

35 "In perfetta uguaglianza nel vestire, e assoluto divieto del lusso e comunione dei beni". Apparently, the King himself came up with the ceremonial for the colony, but there is scholarly agreement in attributing the idea to some members of the Gran Consiglio di Stato, an advisory council of reformist and masonic leaning. Ibid., 116. 
scientist Spallanzani, and the Veronese poetess Silvia Curtoni Verza. She had crossed paths with the famous naturalist Alberto Fortis in 1784 and had kept a friendly correspondence with him that caused her much trouble during the separation trial. This friendship, however, also brought her honour by association and placed her within the European Republic of Letters. ${ }^{36}$ As her communication to the Academy of Lisbon of Fortis' discovery of elephant bones testifies, she was active in a network of intellectuals exchanging ideas, facilitating the dissemination of information and of the latest scientific findings. Apparently, it was Alberto Fortis and Melchiorre Delfico, both friends of Filangieri, who supported her interests in economics and law, and encouraged her studies in those subjects.

In 1788 , for the first time, the "chinea issue" offered Pimentel the opportunity to intervene in a political debate. The homage of the chinea (which means "kneeling") was a yearly tribute, dating back to Charles of Anjou, that the King of Naples owed to the Pope as the Kingdom of Naples was considered a feud of the Papal State. The King's ambassador would lead a richly adorned white horse carrying a coffer with 7,00o ducats to kneel in front of the Pope during the celebration of Saint Peter. When at the beginning of the eighteenth century, the Emperor of Austria and King of Naples, Charles vI, refused to pay this tribute, Neapolitan jurists supported his position by claiming the independence of the Kingdom from the Holy See. ${ }^{37}$ However, the Bourbons thought best to keep a good relationship with the Pope and reinstated the chinea. Later on, Queen Maria Carolina, supported by the Prime Minister and by a sizeable portion of the Neapolitan intellectuals, did not see any need for this yearly humiliation. In 1789, Ferdinand IV refused to send the chinea, thus enraging the Pope. This controversy energised those opposing any claim of sovereignty by the Pope on the Neapolitan State (the De Fonseca Pimentels were among those) and motivated a flurry of literary and juridical writings.

Initially, Pimentel chimed in with poetry, a sonnet dedicated to Ferdinand IV. A choral "we" is used to voice the people's recognition first and foremost

36 Giuseppe Gorani, who was in Naples in 1786-1788, mentioned Pimentel in his Memoires secretes et critiques des cours, Paris $1793,76-77$ as "a lady who gathers in her home in Naples a society of literary people, great friend of all the illustrious people of this capital, and mostly of abbot Fortis" ("une dame qui rassemble chez elle à Naples une societé de gens de lettres, grande amie de tous les illustres de cette capital, et surtout de l'abbé Fortis").

37 The famous jurist and law professor Nicolò Caravita wrote the treatise Nullum jus romani Pontificis in Regnum neapolitanum. Dissertatio historico-juridica (The Roman Pontiff has no right over the Kingdom of Naples. Historic-juridical dissertation), Alethopoli 1707, which was inserted in the list of forbidden books in 1714. Another famous jurist who shared this view was Pietro Giannone, who was excommunicated. 
of the King's power, and their pride in his opposition to the abuse of Rome. Tellingly, she uses the Neapolitan dialect in this sonnet, which endows it with realism and a sense of immediacy. Although still contained here within poetic parameters, this attention to the language spoken by common people would become a pedagogical and political issue in her journalism. Her greatest contribution to the debate on the chinea and, thus, on the legitimacy of the claim of complete independence of the Kingdom of Naples from Rome, was the translation from Latin of the most important book on the topic, Nicolò Caravita's Nullum jus, dedicated to Ferdinand IV. ${ }^{38}$ She divided her work into two parts. In the first, she summarised the historical-juridical assumptions for the thesis by including the ideas and considerations of other authors on the issue. To craft this, quite original, introduction she had to draw on and expand her interest in public law. The second part, the translation itself, was accurate and in plain Italian. The translator contributed to educating and bringing the discussion to a larger audience: those who could not read Latin, but still wished to be informed on the topic without being discouraged by a specialised and unfamiliar language.

Together, with the progressive social experiment of San Leucio, the debate on the chinea had the effect of aligning the reformist court intellectuals with the King. They came to envision themselves as the advisors of a sovereign who could be mentored towards enlightened political choices and social reforms. However, as a consequence of the political situation in France, they were soon to be disabused of their hopes. Ferdinand IV and, especially, his wife Maria Carolina, were quick to recognise the cause of the people's unrest in the ideas and actions of intellectuals and philosophers. They reconnected with the Pope, while the intellectuals felt betrayed and began to follow with interest the developments of the French Revolution: a concretisation of Enlightenment ideals. ${ }^{39}$ According to Schiattarella, one can read this disaffection with the new political stance of the royals in Pimentel's refusal of translating from Portuguese a poetical composition penned by Luigi Raffaele Soye for Queen Maria Carolina's birthday in $1792 .^{40}$ This is also the year in which her last encomiastic work, La Fuga in Egitto, an oratory dedicated to Charlotte Bourbon, Queen of

38 N. Caravita, Niun diritto compete al Sommo Pontefice sul Regno di Napoli. Dissertazione storico-legale del Consigliere Caravita, tradotta dal latino ed illustrata con varie note da Eleonora Fonseca Pimentel, Alethopoli 179o. About Caravita see also note 37.

39 Pimentel's house in Plata della Salata was a meeting place for intellectuals who discussed French politics and read the French Monitore and, later, became the nucleus of the first Neapolitan Jacobin club.

Schiattarella, La Marchesa, 122. 
Portugal and Brazil, appeared. If this is still simply an ideological distancing from the monarchs, the dissemination of Jacobin ideas and clubs in France, and then in Italy and Naples, promoted the beginning of the activist phase for the Neapolitan intellectuals. Pimentel's formal adhesion to the Jacobin clubs, however, was impeded by her gender, her ties to the royal army through her exhusband and her brother and, most of all, by her financial dependence on the court through a pension.

Following the execution of Louis XVI and Marie Antoinette, Queen Maria Carolina instituted a network of spies who helped fill the jails with suspects, most of them held only for their political opinions. Pimentel was under surveillance due to her circle of friends and also because, after all, in her separation trial her own husband had accused her of reading French philosophes and of keeping company with the reformists. With her husband's death in 1795, she was finally completely free, although she had to fight with her brother-in-law in order to get part of her dowry back.

\section{Political Independence and Journalistic Activity}

Suddenly, in December 1797, her royal pension was suspended. That same year Napoleon had created the Cisalpine Republic, which quickly harboured scores of persecuted Neapolitan Jacobins. In Naples, the cultural repression employed preachers who roamed the city and the countryside depicting the Jacobins as devils. Foreign magazines were prohibited, and showing outward indications of foreign influence (such as growing a long beard or wearing long trousers) could warrant exile. Despite the warnings of her old friend de Souza, by 1798 Pimentel was fully adhered to the Jacobin cause and, in August, was arrested and taken to the prison of the Vicaria. The motivation for her arrest was never declared. She was held there for five months with common female criminals. At the arrival of the French general Championnette, the King and the court plundered the banks and fled to Palermo on General Nelson's ship. The people, revolting against the viceroy, freed all the prisoners. The Monitore di Roma announced Pimentel's liberation on this occasion, although there is evidence that at the beginning of January she had already asked for a loan to pay her past rent and the rent of a new apartment in S. Anna di Palazzo, her last domicile.

As soon as she was freed, Pimentel became an active member of the Jacobin committee that pushed for a democratic republican solution. Their most immediate goal was to facilitate the entrance of the French army into the city by taking away the strategic fort of Sant'Elmo from the lazzari, the populace loyal 
to the King. They managed to conquer Sant'Elmo on 20 January, and, apparently, Pimentel stood among the patriots that day, wearing male clothing. ${ }^{41}$ Unfortunately, only fragments survive of the Inno alla Libertà (Hymn to Freedom), the poem she declaimed during the ceremony of declaration of the Republic the following day.

Her most important contribution to this period, and for the majority of literary scholars, remains her work as probable founder, but surely director and journalist for the 35 numbers of the Monitore Napoletano: the main newspaper of the Neapolitan Republic. It is possible that she was entrusted with its direction not only because of her skills, but also because she kept out of any factionalism. Clearly, the other patriots also trusted her business skills as, in his Memorie, Giuseppe Maria Galanti wrote that "The Monitore was given to Eleonora Fonseca Pimentel so that she could get the profit from the sales". 42 Maybe this sentence suggests that she needed the profit from the journal to survive? ${ }^{43}$

A woman director of a political newspaper was an exception at that time. Elisabetta Caminer Turra, a good friend of Alberto Fortis who collaborated with her, had directed the Europa Letteraria since 1777, but that was a cultural journal, not a political newspaper. The Monitore di Roma announced the birth of the Monitore Napoletano thus emphasising the credentials of its director:

A praiseworthy citizen has accepted the task to write everything that will happen in Naples in a newspaper that she named "Monitore Napoletano". This newspaper will have all the merit that an illustrious and literate woman can bestow on it. On top of all her knowledge of sciences, even the most incomprehensible ones, she has command of many languages, among which Latin and Attic Greek are not the last. Her style has some brilliance since Apollo and the Muses did not spare with her their graces. ${ }^{44}$

42 "Il Monitore [...] si è dato ad Eleonora Fonseca Pimentel acciò ne ritraesse l'emolumento della vendita". Giuseppe Maria Galanti, Memorie storiche del mio tempo ed. D. Demarco, Napoli 1970.

43 Pimentel's personal possessions, which could easily fit in a pine box, were sold at an auction after her execution for a total of five ducats. For the detailed inventory see Schiattarella, La Marchesa, 194.

44 "Una benemerita cittadina ha preso sopra di sé l'incarico di stendere tutto ciò che succederà a Napoli in un foglio cui ha dato il nome di "Monitore napoletano". Esso foglio avrà tutto il merito che gli può conferire una donna illustre e letterata. Oltre tutte le cognizioni che la medesima ha delle scienze, benché le più abstruse, possiede eziandio più lingue, 
This period marks the very beginning of political journalism in Italy. In the Cisalpine Republic, it was a Neapolitan exile, Francesco Salfi, who directed the political newspaper Termometro politico di Lombardia. In Naples, before the Monitore Napoletano, only news of events such as spectacles, important weddings, celebrations and military ceremonies were published, without any educational intent. ${ }^{45}$ The Monitore, on the contrary, was a political publication with the declared purpose of reaching as many citizens as possible and of keeping them informed on current events and on the decisions of the republican government. Its first issue appeared on 2 February 1799. It was published twice a week and consisted of four large pages, generally beginning with Pimentel's editorial and reporting the news that collaborators and friends would send her from all over the Kingdom and the rest of the peninsula.

The director's foremost preoccupation, as is evident from her articles and from the epigraph to the last issues which reads "majestas populi", was to find ways to educate lower class people as an issue of moral justice, "right justice compels us to educate the people before condemning them, and each moment is late for this education", but also for political reasons since "the people are distrustful of the patriots because they do not understand them". ${ }^{46}$ Without the collaboration of the people, the existence of the Republic was in jeopardy. ${ }^{47}$ To reach her goal, Pimentel proposed some ingenious strategies. She appealed to the clergy asking them to preach to the people (like the royals had done before), and promoted the sale patriottiche (public places where the people met to be informed and to discuss politics) - even the popular puppet shows could be useful. ${ }^{48}$ Her deep knowledge of Neapolitan society allowed her to single

fra le quali la greca e la latina non tengono l'ultimo posto. Il suo stile ha qualcosa di brillante dopoché Apollo e le muse non furono secolei avare delle loro grazie". (Ibid., 155.)

45 During the Neapolitan Republic at least seven other newspapers and journals appeared regularly. The birth of the political press can be read as instrumental in the diffusion of ideas of political freedom and Italian national unity which, according to Croce, the Neapolitan patriots exported all over Italy: "They knocked down the barriers which separated the various regions of Italy, especially the Southern one from the Northern one, and they formed the common feeling of Italian nationality, not founding it, like before, on a common language and literature, and on the common memories of Rome, but on a common political feeling” (“[...] essi abbatterono le barriere che tenevano separate le varie regioni di Italia, specialmente la meridionale dalla settentrionale, e formarono il comune sentimento della nazionalità italiana, fondandolo non più, come prima, sulla comune lingua e letteratura e sulle comuni memorie di Roma, ma sopra un sentimento politico comune"). B. Croce, Storia del Regno di Napoli, Bari 1965, 229-30.

46 "l'esatta giustizia ci obbliga ad istruire la plebe, prima che condannarla, ed ogni momento è tardi per questa istruzione"; "la plebe diffida dei patrioti perché non gli intende".

47 Il Monitore Napoletano, 2/17 Piovoso, February 5, 1799.

48 C. Gily Reda, "Monitore Napolitano", in Giglio, Eleonora, 79. 
out powerful pedagogical allies in the vernacolo - the language spoken by the common people - and in Neapolitan religious beliefs and traditions. From the pages of the Monitore, she proposed the publication of a small newspaper in Neapolitan dialect containing the abstracts of the news to be read on Sundays, in all churches, by paid readers. ${ }^{49}$ Religion was the other important 'instrument' she suggested the patriots needed to appropriate in order to persuade and win the loyalty of the people. When Championette asked to be present in the cathedral to witness the miracle of Saint Gennaro's blood liquefaction and the 'miracle' did happen - Pimentel reported it on the Monitore describing it as a divine sign of acceptance of the Republic under the French protection, "Even San Gennaro has become Jacobin". 50

Pimentel's insistence on the need to use a language and a symbolism that people can understand, and to see things from the point of view of the 'other' in order to be effective in reaching one's goal, demonstrates not only her deep understanding of communication strategies, but also her belief that without unity there could be no strength in Italy's quest for freedom. In May, when the French troops abandoned the patriots to their fate, while the army of Cardinal Ruffo was marching towards the city, Pimentel wrote:

The present position of Italy is not a disadvantage: Italy will remain a warrior Nation, will fight equipped with her own, not with others' arms; they will understand the great truth, that a people never defends itself well if not by himself, and that an independent and free Italy is a useful ally; if dependent, it is a burden; because freedom cannot be loved halfway and it does not produce its miracles but among the people who are completely free..$^{51}$

Freedom cannot be loved halfway and can bear its fruits only among free people. Soon after writing these words Pimentel would become a martyr for freedom. Unfortunately, it is very likely that the destruction of the records and writings of the Neapolitan patriots ordered by the royals has deprived us of a wealth of information that would be helpful in reconstructing Pimentel's literary career.

49 Il Monitore Napoletano, 10/15 Ventoso, May 5, 1799.

$5^{\circ} \quad$ "Pure San Gennaro si è fatto giacobino!" Il Monitore Napoletano, 26/2o Fiorile, May 9, 1799.

51 "Lattuale posizione d'Italia, non è uno svantaggio: l'Italia resterà una Nazione guerriera, combatterà del suo, non dell'altrui ferro cinta; si comprenderà la gran verità, che un popolo non si difende mai bene, che da se stesso, e che l'Italia indipendente e libera, è utile alleata; dipendente, è di peso; perché la libertà non può amarsi per metà e non produce i suoi miracoli che presso i Popoli tutti affatto liberi". (Il Monitore Napoletano, 28/25 Fiorile, May 14, 1799.) 
From the very beginning, the personal, the political and the economic were strictly intertwined in her life. Her family's politics, visibility and social ties were decisive in shaping her education. She had easy access to intellectual circles, salons, academies and the court, where she was acclaimed for her talents as improvvisatrice and poetess. However, she belonged to the nobility and, although she was not particularly rich, her main objective seemed to be to obtain more than financial gain, but recognition for her poetic talent and active participation in the Neapolitan and Italian cultural discourse. An image of learned woman soon superseded her publicity as girl prodigy and she used her social connections to find mentors to further her knowledge in traditionally male subjects, such as mathematics, economics and law. Becoming the Queen's librarian was mostly a title of honour. Because of her husband's prejudices and jealousy, during her marriage she struggled to afford books for her studies, she had to fight for her right to maintain correspondence with intellectuals and to keep up her role in society and at court. Following the separation from her husband, she was forced to ask the King for a pension, thus obliging herself economically to the sovereigns through explicit economic ties. Once she lost her father, she intensified the production of poetic genres that were usually commissioned (sacred oratories, encomiastic poems, cantatas) and of translations: we can safely assume that she was trying to implement her meager finances with her intellectual work. One could argue that it was a newly found independence as a woman and writer, as her intensified interaction with the Neapolitan people due to her economic situation enhanced her ideological distancing from the court. The King's suspension of her pension on the grounds that, as a public intellectual, she was suspected of Jacobinism, completely freed her from ties of patronage to the court and provided her also with ideological freedom. During the brief life of the Neapolitan Republic, as director of the Monitore, the cittadina Eleonora Pimentel completely embraced the cause of political freedom in her journalistic writings, and even in the dignified acceptance of her exemplary death.

\section{Bibliography}

\section{Primary References}

Archivio di Stato di Napoli, fondo Gran Corte della Vicaria, ordinamento Zeni, fascio 133, fascicolo 43 .

Bergalli Gozzi, L. 1773. Rime di donne illustri a S.E. Caterina Dolfina cavaliera e procuratessa Tron, nel gloriosissimo ingresso alla dignità di procuratore per merito di S. Marco di S.E. il Cavaliere Andrea Tron. Venezia: Tip. P. Valvasense. 
Caravita, N. 1707. Nullum jus romani Pontificis in Regnum neapolitanum. Alethopoli: s.n.

Caravita, N. 179o. Niun diritto compete al Sommo Pontefice sul Regno di Napoli. Dissertazione storico-legale del Consigliere Caravita, tradotta dal latino ed illustrata con varie note da Eleonora Fonseca Pimentel. Alethopoli: s.n.

Componimenti poetici per le Leggi date alla nuova Popolazione di Santo Leucio da Ferdinando IV re delle Sicilie. 1789. Napoli: Stamperia Reale.

De Fonseca Pimentel, Eleonora. 1775. E. La nascita di Orfeo. Napoli: Raimondi.

De Fonseca Pimentel, Eleonora. 190o [1779]. 'Ode elegiaca di Altidora Esperetusa per un aborto, nel quale fu maestrevolmente assistita da M.R Pean il figlio', in Croce, B. (ed.) Sonetti di Altidora Esperetusa in morte del suo unico figlio. Napoli: Tip. Melfi e Joele.

De Fonseca Pimentel, Eleonora. 1782. La gioia d'Italia. Cantata per l'arrivo in Napoli delle LL. AA. RR. Il Gran Duca e la Gran Duchessa delle Russie. Napoli: s.n.

De Fonseca Pimentel, Eleonora. 1785. E. Il vero omaggio. Cantata per celebrare il fausto ritorno delle loro maestà. Napoli: s.n.

Gorani. 1793. Memoires secretes et critiques des cours, des gouvernemens et des mours des principaux états d l'Italie. Paris: Buisson.

Il Monitore Napoletano (2 febbraio-8 giugno 1799). 2008. (ed. A. Lerra). Menduria-BariRoma: Lacaita.

Urgnani, E. 1998. La vicenda letteraria e politica di Eleonora de Fonseca Pimentel. Napoli: La città del Sole.

\section{Secondary References}

Croce, B. 1965. Storia del Regno di Napoli. Bari: Laterza.

Croce, B. 1926. La Rivoluzione Napoletana del 1799. Bari: Laterza.

Croce, B. 1921. Curiosità storiche. Napoli: Ricciardi.

Croce, B. 1887. 'Eleonora de Fonseca Pimentel' in Rassegna degli interessi femminili. Roma: Tip. Nazionale.

De Liso, D. 1999. 'Sonetti (1770-1798)' in Giglio (1999): 81-120.

D’Episcopo, F. 2008. Eleonora de Fonseca Pimentel tra mito e storia. Napoli: Edizione Scientifiche Italiane.

Franchini, S. and Soldani, S. 2004. Percorsi e presenze di una storia di genere. Milano: FrancoAngeli.

Galanti, G.M. 1970. Memorie storiche del mio tempo. (ed. D. Demarco). Napoli: s.n.

Giglio, R. (ed.). 1999. Eleonora Fonseca Pimentel. Una donna tra le muse. Napoli: Loffredo Editore.

Gily Reda, C. 1999. 'Monitore Napolitano' in D'Episcopo (2008): 65-84.

Giorgio, Adalgisa. 2011. 'Eleonora de Fonseca Pimentel e la rivoluzione napoletana: Una donna eccezionale tra storia, memoria ed invenzione' in Italian Studies 66(3):301-17.

Minichini, S. 1999. 'Il Tempio della Gloria (1768)' in Giglio (1999): 25-81. 
Orefice, A. 2009. La penna e la spada. Napoli: Arte Tipografica Editrice.

Pisano, L. and Veuvy, C. 1994. Parole inascoltate. Roma: Editori Riuniti.

Porcelli, M. 2008. 'La poesía di Eleonora de Fonseca Pimentel' in D’Episcopo (2008): 23-39.

Rao, A.M. (2006) 'Eleonora de Fonseca Pimentel, le Monitore Napoletano et le problème de la participation politique' in Annales historiques de la Révolution française 344: 1791.

Schiattarella, F. 1973. La Marchesa giacobina. Napoli: Schettini Editore.

Urgnani, E. 1997. 'L'opera letteraria di Eleonora de Fonseca Pimentel' in Rivista di letteratura italiana XV. 


\title{
"[S] ome employment in the translating Way": Economic Imperatives in Charlotte Lennox's Career as a Translator
}

\author{
Marianna D’Ezio
}

\begin{abstract}
Although motivated by a genuine passion for writing, money was a constant and pressing issue in Charlotte Lennox's (1730?-1804) career as a writer, as well as in her personal life. In 1747 she married Alexander Lennox, an employee of the printer William Strahan, but their union was unfortunate, especially with regards to financial matters. Lennox eventually achieved much-coveted recognition with the success of her novel The Female Quixote, published anonymously in $\mathbf{1 7 5 2}$. However, her work as a translator is an aspect of her literary career that has not been adequately researched, and indeed began as merely a way to overcome the distressing financial situation of her family. This essay examines Lennox's activity as a translator as impelled by her perpetual need for money, within a cultural milieu that allowed her to be in contact with the most influential intellectuals of her time, including Samuel Richardson, Samuel Johnson, Giuseppe Baretti (who likely taught her Italian), and David Garrick, who produced her comedy Old City Manners at Drury Lane (1775) and assisted her in the publication of The Female Quixote.
\end{abstract}

Diamonds may do for a girl, but an agent is a woman writer's best friend

SANDRA CISNEROS, The House on Mango Street (1984)

In the last years of her life, Charlotte Ramsay Lennox received an anonymous letter. Its purpose was to reprimand one of the most successful British women writers of the eighteenth century for having become inappropriately shabby, noting that "Several Ladies who met M $^{\text {rs }}$ Lennox at $\mathrm{M}^{\mathrm{r}}$ Langton's were astonish'd 


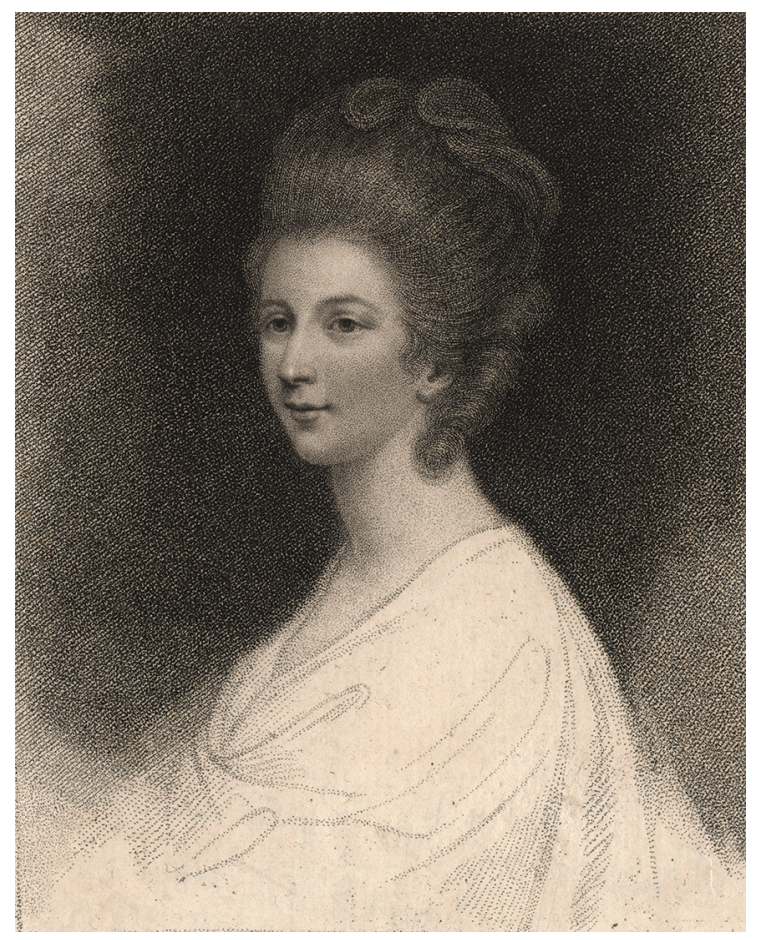

FIGURE 9.1 Portrait of Charlotte Lennox (née Ramsay) by Francesco Bartolozzi, after Sir Joshua Reynolds, stipple engraving, published 1793 .

COPYRIGHT: NATIONAL PORTRAIT GALLERY OF LONDON.

to see a Gentlewoman's hands in such a horrid order". The author of the letter continued to advise that she "for God's sake wash them \& rub back the skin at the roots of the Nails", and ironically - if not cruelly - closes the short epistle by signing it as "a friend" who is pitilessly offering "a hint". Lennox had recently applied to the Royal Literary Fund to obtain financial support for what another anonymous correspondent described, in a letter of recommendation

1 Anon. to Charlotte Lennox, possibly between 1795 and 1801, MS Eng 1269 (47), Houghton Library, Harvard University, reprinted in Charlotte Lennox. Correspondence and Miscellaneous Documents ed. Norbert Schürer, Lewisburg 2012, 245-46. Before Schürer's first comprehensive edition, Lennox's correspondence could only be found in Miriam Rossiter Small, Charlotte Ramsay Lennox: An Eighteenth-Century Woman of Letters, New Haven 1935, and especially Duncan Isles, "The Lennox Collection" Harvard Library Bulletin, XvIII/4 (October 1970), 317-44; XIX/1 (January 1971), 36-6o; XIX/2 (April 1971), 165-86; XIX/4 (October 1971), $416-35$. 
to the committee, as "very great want, poverty \& distress". 2 Receiving such an outrageous note from "a friend" must have represented the public sanction of a desperate situation which was not likely to change. Notwithstanding the allowance she received from the Royal Literary Fund, which stood as "Ten Guineas" in May 1792, "Twelve" in August 1793, "Ten Pounds" in January 1802, and "Seven [additional] Guineas" in March of the same year ${ }^{3}$ until the final decision of granting her "1 Guinea a week", ${ }^{4}$ Lennox died miserably poor on 3 January 1804.

One may wonder at the reasons behind Lennox's failure in accomplishing some kind of economic stability, since she had pursued all the possibilities for financial reward that the eighteenth-century book market could offer an author: patronage (both royal and private), literary peerage, publication by subscription, and well-placed connections with "the male literary establishment of editors, printers, and authors". ${ }^{5}$ Furthermore, she had tried her hand at a large number of genres, particularly in translation, and selected those that appeared to be more remunerative to ride the wave of literary trends that might guarantee marketable products to the booksellers. Lennox's situation was not too dissimilar from the stereotype of Grub Street hacks, as her mentor Samuel Johnson knew very well. Evidently, not being an aristocrat who could cultivate writing as a mere pastime, she did need to write to make a living, although her status as a woman writer contributed little to relieve her economic position (see figure 9.1.). Additionally, she also faced difficulties in her marriage, with her husband, Alexander Lennox, seemingly unable to assist her and their two children in providing life necessaries. When considering the limitations of her surroundings a male-dominated literary marketplace, the challenges of being legitimised as

2 "Mrs Charlotte Lennox, Authoress of The Female Quixote, Euphemia, Eliza, The Translation of Sully's Memoirs, Madame La Valiere's Meditations \&c. - Brumoire's [sic] Greek Theatre, \&c.\&c.\&c.\&c ... is now Living, though at an extremely advanced age, \& in very great want, poverty \& distress - She has always been highly regarded by people of the first distinction \& particularly so, by the late Duke \& Duchess of Newcastle". Anonymous Letter of Recommendation, May 1792, reprinted in Schürer, Charlotte Lennox, 253-54.

3 Lady Frances Chambers requested that the " 7 guineas additional" [double underlining in the original, MDE] be immediately given to Charlotte Lennox, "too ill \& now too old to be able to assist herself in any way", for her "immediate relief" in consideration of her "great distress for the common necessaries of life". Lady Frances Chambers to David Williams, 20 January 1802, reprinted in Schürer, Charlotte Lennox, 273-74. At the time "a guinea ( $\left.£_{111}\right)$ was the minimum annual contribution possible" (Schürer, Charlotte Lennox, 259 n. 5) that the Royal Literary Fund would grant. Since Lennox apparently received much more money than it was usually conceded, we may assume that her case was indeed desperate.

4 All documents and minutes of meetings related to Charlotte Lennox's Royal Literary Fund Case File have been reprinted in Schürer, Charlotte Lennox, 247-305.

5 Dustin Griffin, Literary Patronage in England, 1650-1800, Cambridge 1996, 191. 
a professional and independent woman writer, the wretched condition of an unfortunate marriage, and her particularly quarrelsome attitude to boot - the reality that the book market of the time did not provide her with financial stability is not too implausible. However, I argue that the main justification for Charlotte Lennox's failure to achieve financial independence was instead connected to the impossibility for a woman writer and translator to move away from the system of patronage to gain independence as a professional author in her own right, and even start her own literary enterprise. Disillusioned by her failed attempt to emancipate herself from the patrons and publishers she appeased in the first half of her career, Lennox longed to be in charge of her own periodical and to have the copyright to her own writings. It stands to reason that the restrictions placed on eighteenth-century women writers solely functioned to prevent their acknowledgement as self-determining authors.

By looking at Lennox's career as a translator, this chapter will show that overcoming her economic imperatives did not help Lennox either to overcome the limitations imposed on her sex. In her case, she was eventually defeated by the boundaries of double-edged limitations: at once, a needy author writing for money, and a woman writer struggling to find a niche in the male domain of published literature.

\section{Lennox and Patronage}

Unlike the wealthy Elizabeth Montagu, "Queen of the Bluestockings" and one of the distinguished "Nine Living Muses of Great Britain", 6 Lennox came from a different background which may partly explain her adverse relationships with a number of contemporary women writers. The daughter of a Captain of an independent company, Charlotte Ramsay was born (possibly) in Gibraltar in 1729 or 1730 , moved to New York in 1739, and returned to Britain to live with a wealthy aunt in Essex after her father's death in 1743. Her aunt was ultimately the only person left in the family who could provide a shelter for her. At the age of thirteen, Charlotte found upper-class support for the first time. She left the guardianship of her aunt because the latter "had either gone insane or died",

6 The "Nine Living Muses of Great Britain", namely Elizabeth Carter, Anna Letitia Barbauld, Angelika Kauffmann, Elizabeth Linley, Catharine Macaulay, Elizabeth Montagu, Elizabeth Griffith, Hannah More, and Charlotte Lennox, were the subject of a famous painting by Richard Samuel (1779) originally titled "Portraits in the Characters of the Muses in the Temple of Apollo", now housed at the National Portrait Gallery of London.

7 Schürer, Charlotte Lennox, xxx. 
and went under the protection of Isabella Finch, Lady of the Bedchamber to Princesses Amelia (Emily) and Caroline. Lady Isabella had her own private library and was well connected, both at Court and among the intellectual elite of London, as her lodgings in No. 44, Berkeley Street attracted learned visitors ranging from Lady Mary Wortley Montagu to Horace Walpole.

Being admitted to such exclusive coteries of first-rank intellectuals and patrons of the arts was "by any reckoning an auspicious start to a literary career", and prompted Lennox's first literary endeavour, which was dedicated to Lady Isabella and possibly aimed at publicly recognising "the obligations you have conferr'd on me". ${ }^{9}$ In 1747, although the author signed her dedication to Poems on Several Occasions as "Charlotte Ramsay", she had already married Alexander Lennox, who later proved to be "the most ungrateful of men"10 and "a most unnatural father"11 and yet, at the time of their marriage, was a competent employee of London printer William Strahan. ${ }^{12}$

Her "low" marriage with Lennox could have been reason for the reluctance of her first benefactor to continue patronage. She was forced to find other ways to sustain herself and her husband, such as acting in performances at Richmond in the years ${ }^{1748-50}$, still under the name of Charlotte Ramsay. In the same period, she befriended Samuel Johnson and was introduced to his entourage in a famous episode at the Ivy Lane Club, where the Doctor promoted a "whole night of festivities" to celebrate Lennox's first novel Henrietta, and thus sanctioned her official "admission" into the literary arena. ${ }^{13}$ This episode was symbolic in many ways. On one hand, being literally "crowned" as an author allowed Lennox to identify herself as a professional writer who could follow in the footsteps of her mentors - Samuel Johnson, David Garrick, James Boswell and Samuel Richardson - and aim to become a waged producer of the new commodity of her age: the novel. From that moment, she might have started to view herself, and her career, as ambitiously turning from a mercenary writer still learning the ropes, to a specialised author whose financial reward would guarantee her a solid literary reputation. On the other hand, however, as

$8 \quad$ Norma Clarke, Dr Johnson's Women, London 200o, 68.

9 [Charlotte Lennox], Poems on Several Occasions: Written by a Young Lady, London 1747.

10 Charlotte Lennox to James Dodsley, 30 January 1793, MS Hyde 10 (413), Houghton Library, Harvard University, reprinted in Schürer, Charlotte Lennox, 214-16.

11 Charlotte Lennox to [Richard Johnson], 22 August 1793, Royal Literary Fund Archive, reprinted in Schürer, Charlotte Lennox, 234-36.

12 For full biographical details on Lennox see Small, Charlotte Ramsay Lennox; Isles, "The Lennox Collection", and Schürer, Charlotte Lennox. Susan Carlile has recently published a new biography entitled Charlotte Lennox. An Independent Mind, Toronto 2018.

13 The whole story is narrated in Sir John Hawkins, The Life of Johnson, LL.D., ed. O.M. Brack, Jr., Athens and London 2009, 286-87. 
Catherine Gallagher has clearly demonstrated, her "entrance into the world of letters" was also perceived by those attending the ceremony with uneasiness, since "the respectable domestication of female authorship" represented by Lennox's sanctioned position as an intellectual occurred at "the Devil's tavern" and rather resembled a "debauch". 14 This "double" attitude of her contemporaries towards Lennox's position as a woman writer characterized her entire literary career, which was dominated by both the need for money and the want of recognition as an author legitimised by her own professional writing.

Lennox's official acknowledgement implied a reassessment of her literary reputation based on the assumption that prestigious, aristocratic patronage was one facet of the manifold options the book market had to offer. Publishers and booksellers, she realised, could also be "patrons" themselves. In order to establish a solid network of associations with the most prominent publishers of the time, she had to reconsider which literary genres could allow her secure and profitable publications, as well as a stable status in the literary marketplace. Indeed, novels could be rewarding; however, they were neither a "safe" genre through which to establish a significant reputation, nor would they promise a permanent source of income. ${ }^{15}$ Lennox therefore launched into a versatile literary career, which only partially consecrated her name as a novelist - in fact she only wrote six novels ${ }^{16}$ - and instead included works ranging from collections of poems, plays, serialised essays, a periodical, and translations. In keeping with the stereotype of the Grub Street author, she modelled herself after Dr Johnson, the "patronless poet [who] had become virtuous through privateness and privation". ${ }^{17}$ Lennox also fashioned her own "public" figure through the rhetoric of underestimating her own skills, as in the following excerpt from one of her letters to Samuel Johnson:

Tho I am far from thinking writing my talent [and] I am sure it is not my inclination, yet since my ill[ness o]ne has made it the only means of my

14 Catherine Gallagher, Nobody's Story. The Vanishing Act of Women Writers in the Marketplace, 1670-1820, Berkeley and Los Angeles 1994, 145-47.

15 As a matter of fact, " $[\mathrm{t}]$ he average copyright fee from one novel was roughly equivalent to the annual wages of a laundry, scullery, or dairy maid, and therefore entirely inadequate [...]. To obtain a respectable income of at least $£_{5}$ o per annum, a novelist would have to write and publish as many as ten novels a year", Cheryl Turner, Living by the Pen. Women Writers in the Eighteenth Century, London and New York 1992, 116.

16 In chronological order: The Life of Harriot Stuart, London 1750; The Female Quixote, London 1752; Henrietta, London 1758; Sophia, London 1762; The History of Eliza, London 1767; Euphemia, London 179o. On the authorship of The History of Eliza, see Norbert Schürer, "A New Novel by Charlotte Lennox", Notes \& Queries n.s. 48/4 (December 2001), 419-22.

Gallagher, Nobody's Story, 151. 
Subsistence [at] present if you think me not wholly unworthy of your recommendation I woud [sic] intreat your interest with the Booksellers to procure me some employment in the translating Way, as this woud [sic] be a great deal easier then [sic] Composition, I am perswaided [sic] can make it as advantagious [sic] by industry and having been already engagd [sic] in it know what I am capable of doing by proper application [...].18

Samuel Johnson was not the only literary peer Lennox asked to negotiate with publishers to "procure [her] some employment in the translating Way", especially between the decades of 1750 and 1770, when the pace of her literary activity was at its peak. In 1751, Lennox had lamented "the Condition to which fortune [had] reduced [her]" to Samuel Richardson, himself a printer. Feeling "wholly unfit [...] to struggle with the morti[f]ications of a dependant State", ${ }^{19}$ she took the liberty to send him the second volume of The Female Quixote to solicit his opinion on it.

Besides mentoring his young protégée, ${ }^{20}$ Richardson also enthusiastically provided work for Lennox. In April 1752, he wrote to mediate between her and Robert Dodsley concerning the translation of Voltaire's Siècle de Louis XIV $(1751),{ }^{21}$ which was her first, official work as a translator, although her name did not appear in the printed edition..$^{22}$ This experience not only emphasised the nature of a translator's work as something accomplished "behind the scenes", with little or no public recognition, but also taught Lennox the hardships of the "translating Way". Richardson wrote to propose the endeavour at the beginning

18 Charlotte Lennox to [Samuel Johnson], 3 February 1752, MS held at the Chicago Historical Society, reprinted in Schürer, Charlotte Lennox, 23-25.

19 Charlotte Lennox to [Samuel Richardson], 21 November 1751, TS 934.5, III, 296 (TSM 394.39), Harvard Theatre Collection, Houghton Library, Harvard University, reprinted in Schürer, Charlotte Lennox, 8-10.

$20 \quad$ "You are a young Lady have therefore much time before you, and I am sure, will think that a good Fame will be your Interest. Make therefore, your present work [i.e. The Female Quixote] as complete as you can, in two Volumes; and it will give Consequence to your future Writings, and of course to your Name as a Writer". Samuel Richardson to Charlotte Lennox, 13 January 1752, MS Eng 1269 (19), Houghton Library, Harvard University, reprinted in Schürer, Charlotte Lennox, 21-22.

21 "Madam, $\mathrm{M}^{\mathrm{r}}$. Dodsley has a small Thing to translate from the French with Dispatch. You have asked me if I knew of any thing of that kind. I know not a better Writer, nor a worthier Bookseller, to recommend to each other, than Mrs. Lennox and Mr. Dodsley". Samuel Richardson to Charlotte Lennox, 6 April 1752, MS Eng 1269 (20), Houghton Library, Harvard University, reprinted in Schürer, Charlotte Lennox, 34-35. Lennox's translation was published by Robert Dodsley in July $175^{2}$ as The Age of Louis XIV. Translated from the French of M. De Voltaire.

22 In $175^{1}$ she had already published extracts of her translation of the French Memoires de Maximillien de Bethune (see below) in one volume as The Memoirs of the Duke of Sully; 
of April 1752, and her translation appeared in July of the same year: Lennox thus took around two months to complete her Age of Lewis XIV, which was published in two volumes. Meanwhile, the second edition of her most successful novel, The Female Quixote, was under publication (it appeared on 2 July) and - as her correspondence with one of her collaborators, John Boyle, Earl of Cork and Orrery, dated May 1752, shows - she had also started the project Shakespear Illustrated.

In his way, Johnson proved extremely helpful in another direction - that is, writing dedications for her works. As Schürer notes, Fleeman listed seven recognisable dedications that Johnson wrote for Lennox's publications. ${ }^{23}$ Accordingly, Johnson further promoted her fame among his circles of friends and intellectuals, and encouraged their illustrious and genuine concern for her career. Oliver Goldsmith, for example, wrote the epilogue to her comedy The Sister (1769), based on her novel Henrietta, although the play failed ignominiously and was withdrawn after its first performance at Covent Garden. David Garrick patronised the staging of her play Old City Manners $(1775)^{24}$ at Drury Lane, and other intellectuals, writers, or simply amateurs contributed to Lennox's translations and to her periodical The Lady's Museum. Interestingly, she found herself surrounded by male contributors. In the development of her career, which ran parallel to the polishing of her skills and objectives, her collaborators also transitioned from the literary patrons of the London literary scene, such as Johnson, Richardson, and Goldsmith, to young writers seeking their fortune who she herself patronised and mentored.

While Lennox elbowed her way through the literary marketplace of eighteenth-century London to procure work to subsidise her family income, it is difficult not to conceive of her success without observing her reliance on

During his Residence at the English Court; to which he was sent Ambassador from Henry IV. of France, upon the Accession of King James the First, London 1751, and Dublin 1751. According to Schürer, "the question of whether Lennox also translated that version will probably never find a satisfactory answer" (57 n. 2). However, since the two translations are very similar to each other, it is quite obvious that Lennox worked on both.

23 John David Fleeman, A Bibliography of the Works of Samuel Johnson, 2 vols, Oxford 200o, I, 709-12. See also Allan Hazen, Samuel Johnson's Prefaces and Dedications, New Haven 1937. Johnson wrote dedications for The Female Quixote, Shakespear Illustrated, Henrietta, Philander, The Greek Theatre of Father Brumoy, The Memoirs of the Duke of Sully, and Memoirs for the History of Madame de Maintenon (Schürer, Charlotte Lennox, xxxvii).

24 Old City Manners. A comedy. Altered from the original Eastward Hoe, written by Ben Jonson, Chapman, and Marston. By Mrs Lennox. As it is performed at the Theatre-Royal, in DruryLane, London 1775, was an adaptation of the Jacobean play Eastward Ho! (1605) by George Chapman, Ben Jonson, and John Marston. It was successfully performed at Drury Lane six times in November 1775 and then published at the end of the month. 
more traditional patrons: aristocrats. In fact, the (anonymous) publication of her Poems in 1747, dedicated to Lady Isabella Finch, her admittance to Samuel Johnson's own "court" of literati, and Lennox's reliance on Johnson's fame and judgment could not fully guarantee her access to the literary scene as a professional: she needed the official sanction of the court environment. Lennox's career as a writer, and especially as a professional translator, significantly evolved parallel to the prestige bestowed by those to whom she dedicated her works (through Johnson). Her ascent in the London literary milieu of the mideighteenth century, which proceeded very rapidly and employed aristocrats' support, in fact reached its climax with the most remarkable patrons - the Duke of Newcastle and Queen Charlotte - to then decline when she purposely and mindfully emancipated from patronage to establish herself as an independent, professional author. In other words, her career - and consequently her income - worsened when she defied the establishment and attempted an autonomous career as a woman writer and literary entrepreneur. A focus on translation when considering her production is therefore particularly relevant, since, as M. Pieretti put it, translating was "both [...] an emblem of the female condition and $[\ldots]$ a writing strategy that empowered women writers to assume a more central role in the published writings of the eighteenth century" as a practice "that would [...] challenge limits imposed on women writers". 25 Firstly limited only to the "proper" spheres of literature to which a woman writer could apply and translate - French novels, rather than Greek and Latin classics, which were male dominions - translation became Lennox's tool to unfetter both her creativity and her critical opinion on a literary scene dominated by men, and aspire to a recognised status. The "hybridity" of translation as a professional activity represented an essential means to define such status, and at the same time described Lennox's own hybrid position in eighteenthcentury London: poised between professionalism, dilettantism, social classes, patronage, sponsors, and constantly in search of a role for herself as a woman writer aware of her position and potential, as well as her limited prospects.

\section{From Patronage to Independence: The Role of Translation}

Lennox's early attempts at translation convinced her that, as well as being a successful novelist, she could also become a "labourer" of the book market.

25 Marie-Pascale Pieretti, "Women Writers and Translation in Eighteenth-Century France", The French Review, LXV/3 (February 2002), 474-75. 
Novel writing could expose her to public credit, but also wrath and prejudice. The failure of her comedy The Sister, in 1762, emphasised that although "some [playwrights] of her own Sex"26 had achieved success by writing for the stage (for example, Elizabeth Inchbald), respectability and consistency were also essential to her profession, guided as it was by economic imperatives. Undoubtedly, a career in translation, once she had found the "right" sponsors, could be equal to a steady occupation, a proper job in its own right; however, despite the demands of the reading public of her time, Lennox was well aware of the risks that female translators could run by selecting "inappropriate" sources. In 1785, for example, Charlotte Smith was forced to withdraw her translation of Prevost's Manon Lescaut because many considered it an immoral novel. ${ }^{27}$ Most of the translations Lennox undertook in the years between 1753 and 1760, as Norma Clarke remarks, were "serious works of scholarship" 28 by which Lennox intended to establish her fame and, at the same time, claim a niche for herself as a professional woman writer.

Her early experiences as a translator served the purpose of carving out a position in the book market that offered both monetary reward and public visibility. Furthermore, as Pieretti suggests, since translation was perceived as "an endeavour demanding less talent and fewer qualifications than other literary activities", ${ }^{29}$ Lennox could justify her presence in the male-dominated domains of high literature after having acquired prestige with her publication of The Female Quixote. The book translated "by the Author of the Female Quixote", The Memoirs of Maximilian de Bethune, Duke of Sully, ${ }^{30}$ was published by Millar in London in 1755. It was very popular and had numerous editions (both official and pirate), which attest to its reputation. Additionally, together with the previous abridged edition of Sully (1751, also possibly translated by Lennox) and her Age of Lewis XIV, she had decisively oriented her translating career to

26 Charlotte Lennox to [David Garrick], 25 October 1768, Add.Ms. 2930o, f.45, Department of Manuscripts, British Library, reprinted in Schürer, Charlotte Lennox, 115-17.

27 For further examples, see Maristella Trulli, "La traduzione tra trasgressione e formazione: Charlotte Lennox e le altre", in Traduttrici. Questioni di gender nelle letterature di lingua inglese, ed. Oriana Palusci, Naples 2010, 67.

28 Clarke, DrJohnson's Women, 117.

29 Pieretti, "Women Writers", 476.

$30 \quad$ Memoirs of Maximilian de Bethune, Duke of Sully, Prime Minister to Henry the Great. Containing The History of the Life and Reign of that Monarch, And his own Administration under Him. Translated from the French, by the Author of the Female Quixote. To which is added, the Tryal of Ravaillac for the Murder of Henry the Great. In Five Volumes, London 1756. The French Memoires de Maximillien de Bethune, Duc de Sully, Principal Ministre de Henry le Grand (1745) was itself an adaptation of Sully's own Memoires (1638) by Pierre Mathurin de l'Écluse des Loges. 
"safer" genres - in this case, historical memoirs. Lennox's first experience in translation had thus been one of preparation, and had had a positive outcome. Sully became her official introduction into the realm of translation, more so than through novel writing. As she had produced the (anonymous) publication of extracts, the book only needed the endorsement of an influential patron to ensure undisputed success. Sully was dedicated to the Duke of Newcastle, then Prime Minister, and it was Samuel Johnson - more skilled at this kind of literary practice - who wrote the dedication.

At the time of its publication, Sully provided Lennox with agreeable consequences, that is, "a most liberal present" from the Duke, who "declared that he would recommend her to the King as a person who well deserved a pension". ${ }^{31}$ However, on a more practical level it seems that she struggled to obtain full payment for it. In a letter to Millar, she pleads for the money owed for her translation; the letter also exemplifies the difficulty of negotiating this business with publishers and booksellers, since on one side she clearly makes her point about being paid, while on the other is mindful of her reliance on Miller for further work:

Sir,

I hope you will not think it an unseasonable importunity, if now that I have entirly finishd [sic] my work, I beg the favour to see you to morrow or next day as it shall suit your conveniency. I was resolved, however pressing my exigencies might be, that I would not trouble you as I have too often done with application for money before it was due, and althoug[h] I have now completed the work, I would wait your leisure, were it not for a disagreeable circumstance that forces me to solicit you to come sooner than you without knowing my reasons probably intended.

[...] Do not imagine I want to importune you, but let me say this once that $[. .$.$] the Work I proposed [i.e. her next translation],$ which I am sure will be an advantagious [sic] to you, I will undertake it with more chearfulness [sic] than ever I did any thing in my life. ${ }^{32}$

31 Griffin, Literary Patronage, 206. Griffin also clarifies (206-7) that "[r]oyal pensions paid to other writers in the 175 os and 176 os commonly amounted to £2oo to £3oo per annum, and at this point Charlotte Lennox would have probably found such an amount sufficient to support herself and her husband". 
Despite such monetary hindrances, Lennox's launched her career as a translator, and she safely relied on translation as a source of income. Such endeavour, which Mirella Agorni defines as a "secondary activity", given the "derivative nature of translation", ${ }^{33}$ broadened Lennox's network of high-rank relationships and provided her and her family with the economic support they needed. The Duke and Duchess of Newcastle in fact later arranged for Lennox to live in apartments in Somerset House for several years. This occurred after the publication of a new edition of Lennox's third novel Henrietta (1758), dedicated to the Duchess as a "debt of gratitude" which the author was "impatient to pay". ${ }^{34}$ However, it is still unclear and puzzling to Lennox's scholars that she unceremoniously declined the Duke's offer to recommend her to the King for a pension in favour of her husband, for whom "she solicited a place, which the Duke promised to procure him the first opportunity". ${ }^{35}$ She nonetheless regretted this decision later in life, when out of job, in need for money, and "break[ing] through decorums" she would address several former patrons, literary peers, and publishers, and literally beg them to procure some work to save her and her son - her daughter had died in 1783 at the age of 17 - from destitution:

\section{Sir,}

It is with great confusion that I take the liberty to importune You, who know me only by name, with this application and my distress may be easily imagind [sic], when it forces me to break through decorums which I always wishd [sic] to observe - but I am a Mother, and see an only child upon the brink of utter ruin. Driven as he was first, to desperation by a most unnatural father; and then deserted, and left exposed to all the evils that may be well expected from the dreadful circumstances he is in [...] I have in vain used my utmost endeavours to mortgage the poor income I hold from a husband, whose fortune I have made by the sacrifice of my own $[\ldots] .36$

33 Mirella Agorni, "A Marginal(ized) Perspective on Translation History: Women and Translation in the Eighteenth Century", Meta:Journal des Traducteurs, L/3 (2005), 819.

34 "I shall never forget Your Grace relieved my distress last Winter", Charlotte Lennox to the Duchess of Newcastle, 6 October 176o, Add.Ms. 33067, f.23o, Department of Manuscripts, British Library, reprinted in Schürer, Charlotte Lennox, 106-8. The protagonist of the novel, Henrietta, has the same name as Lennox's correspondent and patroness Lady Henrietta (Harriet) Godolphin Duchess of Newcastle.

35 Griffin, Literary Patronage, 207.

36 Charlotte Lennox to [Richard Johnson], 22 August 1793, Royal Literary Fund Archive, reprinted in Schürer, Charlotte Lennox, 234-36. 
The 175 os and 176 os proved to be Lennox's most productive years: in two decades, she managed to publish three novels, one critical edition of Shakespeare's sources, a pastoral drama, six substantial translations, and a periodical. The aura of protection of her patrons and literary peers developed accordingly. From Lady Isabella Finch, to the literary advice of intellectuals gathered around Richardson and especially Johnson; from the dedication of her works to the Duke and Duchess of Newcastle and the Countess of Northumberland, to the climax of her public career with the dedication of her Greek Theatre of Father Brumoy (1759) to the Prince of Wales, and eventually a subscription edition of her Original Works - comprising her novels, her comedy, and the pastoral drama of Philander $(1757)^{37}$ - to Queen Charlotte, these years also allowed Lennox to learn the literary trade. Writing for money was subject to the rules of the book market, as well as the taste of the reading public. Learning about both, although labouring very intensely, promised the security of indisputable revenues, and raised the condition of an author to a way of life. ${ }^{38}$

Besides having ensured the support of patrons and literary peers, Lennox achieved a status that other contemporary women writers had not managed to accomplish: being a leader of several intellectual ventures. At this stage of her career, her personal and literary experience retraced that of her principal mentor, Samuel Johnson. Shakespear Illustrated (1753-1754), ${ }^{39}$ and particularly the three volumes of the Greek Theatre of Father Brumoy (1759), represented Lennox's highest achievements in the literary milieu of her time, and definitively sanctioned her official and prestigious presence in the marketplace. Financed by "a congerie of booksellers" ${ }^{40}$ - Millar, Vaillant, Baldwin, Crowder, Johnston, Dodsley, Wilson and Durham - the scholarly translation into English of Brumoy's French edition of classical Greek plays was a remarkable example of literary collaboration in which Lennox acted as mentor and manager of a

37 The proposal for a subscription edition of Lennox's Original Works consisting of The Female Quixote; Shakespear Illustrated; Henrietta; Sophia; Eliza; The Sister, a Comedy; Philander, A Dramatic Pastoral, And Other Pieces, never before printed, was "almost certainly written by Johnson". As Schürer points out, in drafting her proposal Lennox was "appealing to her readers $[\ldots]$ to recognise (or at least believe) that prior to 1775 , the main beneficiaries of publishing were the booksellers, while this particular edition [...] would bring her prof-

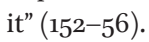

38 On this, see also Manuel Portela, "Writing for Money, or The Distresses of a Hired Writer", Paper written for the 25th Annual Conference of the Portuguese Association for AngloAmerican Studies, Universitade de Trás-os-Montes e Alto Douro (Vila Real, 22-24 April 2004), 5 .

39 See Women Reading Shakespeare 1660-1900. An anthology of criticism, eds Ann Thomson and Sasha Roberts, Manchester 1997, 15-21.

40 Clarke, DrJohnson's Women, 117. 
learned coterie of men of letters. Samuel Johnson, the Earl of Cork and Orrery, James Grainger, John Borryeau, Gregory Sharpe, and "an unnamed 'young gentleman' "41 all contributed to the success of her project, and the creation of a much-coveted reputation.

At the same time, after having established her authority as a translator of scholarly works, she could also safely move into the realm of "lighter" literature, and hazard the translation of entertaining novels and memoirs, such as The Memoirs of the Countess of Berci (1756), Memoirs for the History of Madame de Maintenon (1757), and later, Meditations and Penitential Prayers, by the celebrated Dutchess de la Vallière (1774). ${ }^{42}$ With the exception of Vallière's Meditations and Prayers, translated and published in the 1770s, and bearing the full name of its translator on the cover page, both Berci and Maintenon still quote their translator as "the Author of the Female Quixote". However, given the limited success - if not patent failure - of Berci, which was torn to shreds by many critics and reviewers, it might have relieved Lennox that her translation of two French works combined into the Memoirs of the Countess of Berci had no indication of the author. Her name was, therefore, not involved in a critical attack. ${ }^{43}$ Berci fused Vital d'Audiguier's Histoire trage-comique de nostre temps, sous les noms de Lysandre et de Caliste (1616) with Claudine de Tencin's Memoires du Comte de Comminge (1735), a short tale that at the time of its publication was protected by anonymity. ${ }^{44}$ However, when Lennox translated it, the novel was well

41 Fleeman, Bibliography, II, 1006-7.

42 The Memoirs of the Countess of Berci. Taken from the French by the Author of the Female Quixote. In Two Volumes, London 1756; Memoirs for the History of Madame de Maintenon And of the Last Age. Translated from the French, by the Author of the Female Quixote. In Five Volumes, London 1757; Meditations and Penitential Prayers, Written by The celebrated Dutchess de la Vallière, Mistress of Lewis the Fourteenth of France. After her Recovery from a dangerous Illness, when she first formed the Resolution of quitting the Court, and devoting herself to a Religious Life. Translated from the French. With some Account of her Life and Character, extracted from Voltaire, Sevigné, and other Writers of that Time. By Mrs. Charlotte Lennox, London 1774 .

43 Despite the harsh reviews of Berci, Lennox's reputation was not affected; in fact, the Critical Review praised her for having "performed her part extremely well" as the translator of an "old romance newly vamped up [...] which contains all the pomp of knight-errantry", Anon., The Critical Review: or, Annals of Literature. By a Society of Gentlemen, London 1756, 313. Lennox later reused parts of her translations, and in the 178 os republished some portions changing most of the characters' names. See Schürer, Charlotte Lennox, 72 n. 16, and Fredrick W. Vogler, "Vital d'Audiguier and Charlotte Lennox: Baroque Studies, Women's Studies, and Literary Resurrection”, Romance Notes, xxxvi/3 (Spring 1996), 293-99.

44 Claudine Alexandrine Guérin de Tencin's novel was attributed to her after her death (1749) by Guillaume-Thomas-François, abbé Raynal, yet she was known to be the authoress, at least among her circle of friends. See Marianna D'Ezio, "Introduction" to Claudine 
known as having been written by "scandalous" Madame de Tencin. ${ }^{45}$ Indeed, both d'Audiguier's Lysandre et Caliste and de Tencin's Comminge can be considered as odd choices for translations. Little or no evidence remains to explain Lennox's reasons for translating such works, which may well have arisen from the demands of the reading public. Yet her exaggerated reaction to the miserable failure of the volumes, as attested by Samuel Johnson's reply, ${ }^{46}$ suggests an unusual interest for genres that she had not yet practised in translation. Not surprisingly, she released her next translation within the following months, this time sponsored by a coterie of booksellers, and with a prestigious dedication that Johnson wrote for the Countess of Northumberland on behalf of Lennox. Memoirs of Madame de Maintenon was in fact a "rehabilitation" for Lennox in terms of reputation and prestige, and as she received $£ 86$ for her translation, she was "being paid at the high end of the scale", 47 thus confirming her influence in literary matters, and aligning her position with that of other European translators, such as Luise Gottsched, who was translating Maintenon into German the same year. ${ }^{48}$ Vallière further confirmed Lennox's status as translator. A receipt she received from James Dodsley indicates that, by 1774, she was paid "several months in advance", 49 which might be a clear sign of the respect she had earned, compared to two decades earlier, when she had had to "beg the favour" and "appl[y] for money before it was due" to publisher Andrew Millar.

\section{The Failure of Independence: From Success to Poverty}

Given the success Lennox had achieved throughout the years 1750-176o, it is surprising that on 6 October 176o, writing to the Duchess of Newcastle, she still - and vehemently - lamented her dismal condition:

I have the comfort of hearing [...] that Your Grace continues Your favourable intentions with regard to $\mathrm{M}^{\mathrm{r}}$ Lennox, and this hope supports me in

Alexandrine Guérin de Tencin, The History of the Count de Comminge, translated by Charlotte Lennox, Newcastle upon Tyne 2011, 1.

45 René de Castries, La Scandaleuse Madame de Tencin (1682-1749), Paris 1986.

46 Samuel Johnson to Charlotte Lennox, 30 July 1756, MS Eng 1269 (8), Houghton Library, Harvard University, reprinted in Schürer, Charlotte Lennox, 67-73.

47 Publication Ledger for Maintenon, reprinted in Schürer, Charlotte Lennox, 76-79.

48 Johann Christoph Gottsched, Luise Gottsched, and Dorothea von Runckel, Nachrichten, die zum Leben der Frau von Maintenon und des vorigen Jahrhunderts gehörig sind, 3 vols, Berlin and Stettin $1757^{-1761 .}$

49 Receipt (Charlotte Lennox from James Dodsley), 10 January 1774, MS Hyde 10 (418), Houghton Library, Harvard University, reprinted in Schürer, Charlotte Lennox, 140. 
my present Slavery to the Booksellers, whom I have the mortification to see adding to their heaps by my labour, which scarce produce me a scanty and precarious subsistence. ${ }^{50}$

If translation had given Lennox some importance in the literary marketplace, and a reputation as an intellectual "worker", it had also apparently drained her energy. From Berci to Brumoy, in a time span of three years, she had released four significant translations, and by the beginning of the 176os, right after the launching of her own periodical, The Lady's Museum, she became ill. Her literary enterprises had given her publicity and fame. Publishers and booksellers would now offer her work and she herself drafted several projects, which she later abandoned. However, her constant need for money prompted her future decisions in terms of publication: she attempted to regain the copyright of all her works, and meanwhile, launched into the composition of a periodical, which proved a fiasco. In addition, during the last decades of her life, although she tried to recuperate the positive influence of aristocratic patrons, she found herself alone and destitute. Besides relying on James Boswell and his family for support, and eventually on the Royal Literary Fund, she lost the protection of the prestigious relationships that in the past had allowed her to dedicate her works to the Prince of Wales and to the Queen. In late 1775, for example, after asking permission to dedicate her play Old City Manners to the Countess of Bute, the latter replied bluntly that "[she] wou'd be Glad to be of any service to her, but is averse to seeing her name in print". 51

In fact, Lennox's intention to become an independent author and emancipate from what she had termed "Slavery to the Booksellers" was not an innovative choice. Before The Lady's Museum was published in 1760, other women writers had attempted the publications of periodicals, with reasonable success. ${ }^{52}$ Nevertheless, The Lady's Museum offered her a fully self-managed space

50 Charlotte Lennox to the Duchess of Newcastle, 6 October 176o, Add.Ms. 33067, f.23o, Department of Manuscripts, British Library, reprinted in Schürer, Charlotte Lennox, 106-8. According to Duncan Isles, the Duke of Newcastle had helped Alexander Lennox to find an employment in the Customs Office. See Isles, "The Lennox Collection", 59 n. 121, and Schürer, Charlotte Lennox, $120 \mathrm{n}$. 11.

$5^{1}$ Mary Stuart, Countess of Bute, to Charlotte Lennox, 14 November 1775, MS Eng 1269 (40), Houghton Library, Harvard University, reprinted in Schürer, Charlotte Lennox, 165-66.

52 Before Lennox, Delarivier Manley, for example, contributed to and edited The Examiner (1711), while Eliza Haywood had her own periodical, The Female Spectator (1744-1746). For an overview, see Alison Adburgham, Women in Print: Writing Women and Women's Magazines from the Restoration to the Accession of Victoria, London 1972, and Manushag N. Powell, Performing Authorship in Eighteenth-Century English Periodicals, Lewisburg 2012, esp. 131-92. 
to continue both her mentoring activity, by employing a young and inexperienced collaborator such as Hugh Kelly (or Kelley), ${ }^{53}$ and experiment with translation as a means to defy the "secondary literary value" 54 ascribed to it as well as a locus to practice the creative re-writing of source works..$^{55}$ The Lady's Museum is an interesting experiment in its genre. The periodical, which had only been published in nine issues before being interrupted, featured the serialisation of several translations that demonstrated the wide range of interests that Lennox cultivated at the time. The History of the Count the Comminge, for instance, which had been a failure when it had been published in Berci, was probably a concern for Lennox as it reappeared in The Lady's Museum with few changes. Lennox's "version" of Tencin's novel confirms at times her deliberate inclination towards adaptation, rather than literal translation, as was common to many other women writers and translators of her time. ${ }^{56}$ The inclusion of her translation of selections from François de Salignac de la Mothe Fénelon's

53 Hugh Kelly (or Kelley) was an Irish dramatist and poet who arrived in London in 176o in search for work. He was 21 at the time of his collaboration with Lennox. For the extent of his participation in Lennox's periodical and for biographical detail, see Robert R. Bataille, The Writing Life of Hugh Kelly: Politics, Journalism, and Theater in Late Eighteenth-Century London, Carbondale 2000, 5 .

54 Agorni, "Marginal(ized)", 819.

55 Lennox's opinion on translation as a "flexible" text, which did not necessarily have to passively transpose the original work, was in line with numerous other (women) translators of her time. As for French translators, such as Anne Dacier, Emilie Du Châtelet, MarieJeanne Riccoboni and Mme Thiroux D'Arconville, M. Pieretti posits that "writing and translating clearly constituted two facets of the same creative process" (Pieretti, "Women Writers", 483). In Italy, for instance, the examples of Luisa Bergalli Gozzi, who "freely" translated Anne-Marie du Boccage's Les Amazons (1749), and Rosa California, whose Breve Difesa dei Diritti delle Donne (Short Defence of the Rights of Woman, 1794) can be considered as a pseudo-translation of Mary Wollstonecraft's Vindication of the Rights of Woman (which California had read in French) are representative of a similar trend. In a letter to David Garrick about the possibility of translating Racine's play Bajazet (1672), Lennox clearly shows that the practice of the time undoubtedly implied the "adaptation" of the source text to suit the target audience, as well as the "reshuffle" of the plot itself and even its ending: "Sir, I need not tell you, who are so good a critic in the french [sic] drama, that Racine's Bajazet is allowd [sic] by all good judges to be one of the best of his tragedies, my own humble opinion coinciding with this general one, I resolved to translate it, and hazarding a few alterations adapt it to the taste of an english [sic] audience. [...] I think it might be turn'd entirly [sic] new, and by one of those sudden revolutions common enough in the turkish [sic] government, Bajazet instead of being murdered, might be placed upon the throne, as for Roxana [...] she should die, her death might be rendered more affecting some circumstances of terror and pity, which are not found in the original". Charlotte Lennox to David Garrick, 4 August 1774, Y.c. 1665, Folger Library, reprinted in Schürer, Charlotte Lennox, 143-46.

56 For detailed examples, see my edition of Comminge, 57-58. 
Traité de l'Éducation des Filles (1684) shows Lennox's involvement in the issue of women's education, and her belief in the exercise of "proper studies" as tools to promote women's awareness of their role in society. ${ }^{57}$ Here translation turns into a device to suit the purpose of the whole periodical, leaving aside Fénelon's religious teachings completely to concentrate instead on the pedagogical and reformist aspects of Fénelon's work. Finally, her "History of Bianca Capello", possibly a translation of the highly popular Italian tale ${ }^{58}$ - or perhaps her adaptation of the novella dedicated to Bianca Capello (or Cappello) in Celio Malespini's Ducento Novelle (1609) - witnessed Lennox's familiarity with Italian, a language she possibly started learning from the controversial intellectual Giuseppe Baretti around $175^{2}$ (the year she also began working on Shakespear Illustrated).

Overall, the serialisation of these translations, as well as her novel The History of Harriot and Sophia, was an attempt to popularise literary genres, both "high" (as in the case of Fénelon's pedagogical Treatise) and "low" (as for "Bianca Capello" and The History of the Count de Comminge). Not only could Lennox display her abilities in translating, adapting and interpreting texts from diverse cultural and linguistic backgrounds, she also joined the custom of the time according to which the book market had to be "constantly fed with new commodities",59 since the practice of reading had turned into a consumerist activity, and books themselves had become objects of consumption. ${ }^{60}$ From this perspective, The

57 See Claire Boulard Jouslin, "Conservative or Reformer? The History and Fortune of Fénelon's Traité de l'Éducation des filles in Eighteenth-Century England", The Journal for Early Modern Cultural Studies, XII/4 (Fall 2012), 48-77.

58 According to Edward W. Pitcher, there seemed to be "no evidence of an English account of her [i.e. Bianca Capello's] life prior to the appearance of the story in Mrs. Lennox's $L a$ dy's Museum", E.W. Pitcher, “Charlotte Ramsay Lennox's 'History of Bianca Capello' (176o)", American Notes \& Queries (May 1976), 130-31. The Italian Storia della Vita, e tragica morte di Bianca Capello, Gentildonna di Venezia, e Gran Duchessa di Toscana by Giulio Roberto Sanseverino di Sammartino was published in Berlin in 1776, therefore sixteen years after the first issue of the Lady's Museum. However, one may assume that Lennox had access to the story thanks to her relationships with German intellectuals around the time Sanseverino was teaching Italian there (1760-1770), as her connection with the Gottscheds shows. Duncan Isles reported that Charlotte Lennox sent Johann Christoph Gottsched's wife Luise, herself a translator and a writer, the three volumes of her Shakespear Illustrated from London (Isles, "The Lennox Collection", 423 n. 203), maybe hoping that she would translate it into German, thus contributing to its dissemination in Europe. On Sanseverino, see Wolfgang Adam, "La Italienische Biographie di Johann Georg Meusel", in Traduzioni e Traduttori del Neoclassicismo eds G. Cantarutti, S. Ferrari, and P.M. Filippi, Milan 2010, 23-34.

59 Portela, "Writing for Money", 3.

6o On the "commodification" of the practice of reading (and writing), see The Consumption of Culture 1660-18oo: Image, Object, Text eds John Brewer and Ann Bermingham, London 
Lady's Museum intentionally tried to satisfy the demands of its contemporary public, and most importantly, the needs of its female readership. ${ }^{61}$ It was also Lennox's own opportunity to voice her resentment towards the system of aristocratic patronage, which excluded her from pursuing an independent career. In the novel first serialised in her periodical as "The History of Harriot and Sophia", which then became Sophia, Lennox pilloried the attitude of patrons in the character of Sir Charles, who "took upon himself the care of rewarding her friends, [...] presented Mr. Lawson to a very considerable living [and] he procured Dolly's husband a genteel and lucrative employment".62 What had happened for The Life of Harriot Stuart (1750), where she had criticised her first patron Lady Finch through the character of Lady Cecilia, condemning her "peculiar talent, in procuring dependents, by her affected benevolence, whom she never designed to serve, and raising hopes she never intended to gratify", was now repeated and elevated to a more general target: Lennox's explicit censure of the status quo of patrons who flatter themselves in being surrounded by sycophants, but do not recognise true merit and more often tend to forget, and even silence, their expectations, had eventually found its official outburst in her own periodical, and not in a dedicated, patronised novel that had enslaved its author to the vicious circle of patrons, publishers, and booksellers.

Parallel to Lennox's pursuit of an independent authorship ran the "battle" in which she engaged with representatives of power in the book market: publishers. Before the so-called copyright decision by the House of Lords, on 22 February 1774, concerning the Hinton $v s$. Donaldson trial, authors had been subjected to the rule of "perpetual copyright", which de facto authorised printers and booksellers to possess the copyright of all the works they published. The decision ratified the reinstatement of the Statute of Anne (1710), also known as the Copyright Act, which sanctioned the limit for publishers to "own" copyright over a work to fourteen years. ${ }^{63}$ In 1775 , Lennox realised the implications of

1995. According to Janet Todd, Lennox's The Lady's Museum was "interesting mainly [and also] because it helped pioneer the serialising of novels before publication", Janet Todd, The Sign of Angellica. Women, Writing and Fiction, 1660-180o, New York 1989, 133.

61 See for example the sections entitled "Philosophy for the Ladies" and "The Lady's Geography", in which Lennox "popularized" topics and disciplines such as philosophy, geography, and history, for a middle-class reading target. On The Lady's Museum, see also María Jesús Lorenzo Modia, "Education for Women in the Eighteenth-Century Periodical: Charlotte Lennox's The Lady's Museum", in Diferencia, (des)igualdad y justicia / Differences, (In)Equality and Justice eds A. Antón-Pacheco, I. Durán Giménez-Rico, C. Méndez García, J. Neff van Aertselaer, and A.L. Rodríguez Redondo, Madrid 2010, 201-12.

62 Griffin, Literary Patronage, 218; Lennox, Sophia, 826.

63 See Yamada Shōji, "Pirate" Publishing. The Battle over Perpetual Copyright in EighteenthCentury Britain, Kyoto 2012. 
possessing the rights of her own writings, and that such property could be a definitive answer to her needs. Writing to William Hunter, an acquaintance of $\mathrm{Dr}$ Johnson's, Lennox acknowledged that "The late decision with regard to literary property [has] given me a right to reprint my original writings for the benefit of myself and my children". ${ }^{4}$ Until that moment, ownership over her works was a frustrating issue. The copyright of all her works would not only be in the hands of booksellers, but also go automatically to her husband: hers was thus a liminal position, one that Gallagher has termed "doubly dispossessed authorship". ${ }^{65}$ At a moment in life in which she had finally carved out a position for herself in the literary marketplace, and could eventually make money out of her published works by claiming her rights back from unscrupulous printers, she also decided to leave Alexander Lennox. The last straw was likely her husband's decision to deny their daughter Harriot Hollis entry into a school and to instead send her to a convent, against her mother's wishes. Lennox's letter to her husband clearly indicates the animosity between the two, and confirms the desolation of her financial situation:

I have talkd [sic] with $\mathrm{M}^{\mathrm{r}}$ Johnson, and other persons of good sense and experience, upon the expediency of sending Harriet to Boulogne for her education - and they are all of opinion, which they supported with very good reasons, that a Boarding school here, will be equally advantageous, equally cheap, and is liable to fewer inconveniences than a Convent. Their reasons have convinced me, and that is the cause that they will never convince you - therefore I submit to your despotick will, with this condition only, that I go with her, and see her settled - this point I never will give up - the next thing to be considered, is what necessaries must be provided - I will give you a list of what cloaths [sic] and Linnen are usually sent even to the cheapest schools - Half a dozen frocks.

she has two already

a dozen pr of stockings

she has four pr but they are old

half a dozen night caps

she has one

four under petticoats

of this article she has none but rags

\footnotetext{
64 Charlotte Lennox to Dr William Hunter, 18 February 1775, MSoo14/2, Vol. 1B, f.56, HunterBaillie Papers, Royal College of Surgeons of England, reprinted in Schürer, Charlotte Lennox, $157-58$.

65 Gallagher, Nobody's Story, 195-96.
} 


\section{Morning gowns}

of these she has four which I think is enough

Three quilted caps with lace border

of these she has none

a dozen shifts

of these she has five new ones, three not made up - and the others are rags a handsome Skirt, to wear on Sundays

All the skirts she has had, for more than two years past, have been made out of my gowns $[. ..]{ }^{66}$

Once again, Lennox was relying on Johnson's friendship and advice, not only for what concerned her daughter's future, as mentioned in this letter, but also for reasons linked to her regaining the copyright of her works. In a letter dated 29 May 1778, Lennox complained to her mentor about Dodsley's decision to print "another edition of Sully's Memoirs [...] without my consent [and] without consulting me": the tone of the letter is quite peremptory, as she fully realised the consequences of asserting her rights with the publishers, to make money out of such venture:

although by the late decision concerning literary property the copy is mine - I am advisd [sic] to publish it for myself in numbers, and if the partners expect to sell another edition, I have some reason to hope that I may have success by publishing it in this manner, as the purchase will be so much easier - but I must be speed [...]. ${ }^{67}$

Gallagher points out that Lennox's allegation that the copy of Sully's Memoirs in the hands of the publishers "is mine" is but further proof of her apprehension and even anxiety at having been dispossessed of her literary property, not to mention the dispossession she experienced as the "victim of a disinterestedness from which the most ungrateful of men has derived great advantages",68 her husband Alexander Lennox. Indeed, the display of her deprived property aimed at skilfully portraying a public "representation of deserving,

66 Charlotte Lennox to Alexander Lennox, c. 1776-78, MS Eng 1269 (15), Houghton Library, Harvard University, reprinted in Schürer, Charlotte Lennox, 170-74.

67 Charlotte Lennox to Samuel Johnson, 29 May 1778, English MS.537, John Rylands University Library of Manchester, reprinted in Schürer, Charlotte Lennox, 192-94 [my italics, MDE].

68 Charlotte Lennox to James Dodsley, 30 January 1793, MS Hyde 10 (413), Houghton Library, Harvard University, reprinted in Schürer, Charlotte Lennox, 214-16. 
dispossessed authorship", as both Gallagher and Schellenberg have underlined. ${ }^{69}$ Among the reasons for Lennox's failure in terms of establishing a long-lasting, highly professionalised position as a labourer in the book market, and her consequent poverty, Schellenberg mentions Lennox's "inability to forge successful relationships with those beyond her immediate circle" of mentors, patrons, and publishers. This mainly occurred, however, because her ambition - unusual for a woman writer of her time - to be able to sustain her own activity by her commitment to writing could not be fulfilled. Samuel Johnson had magnificently raised his status from a Grub Street hack to that of an influential writer, a successful mentor, and a leading literary figure. In the case of Lennox, her personal attitude, constraints, and willingness to experiment with translation as a business transaction through which she could make money, often resulted in a mere "necessity to take up [her] pen", "be engaged in a War with [the] Booksellers", ${ }^{70}$ and thus "[alter her] circumstances [...] for the better". ${ }^{71}$ However, the outcome could not be the same as Johnson's, since she refused to accept her submission to male-dominated spheres of public and private life, as well as admit the limitations imposed on her own agency. Interestingly, although she repeatedly mentioned numerous projects she was planning to develop independently, none of these projects came to fruition. ${ }^{72}$ The "dependant State" which, in 1751, she had acknowledged as "yet [...] necessary and unavoidable"73 only slightly improved throughout her career, but never developed into a fully independent position, neither recognised by the patrons whom she had wanted to celebrate in her dedications, nor by the publishers,

69 Gallagher, Nobody's Story, 195, and Betty A. Schellenberg, The Professionalization of Women Writers in Eighteenth-Century Britain, Cambridge 2005, 94-119.

70 Charlotte Lennox to Lady Lydia Clerke, 16 June 1777, MS 444/19, Cely-Trevelian Bequest, Royal Society of Antiquaries, reprinted in Schürer, Charlotte Lennox, 183-88.

71 Charlotte Lennox to James Dodsley, 30 January 1793, MS Hyde 10 (413), Houghton Library, Harvard University, reprinted in Schürer, Charlotte Lennox, 214-16.

72 For example, Samuel Johnson proposed her to translate François-Joachim Duport du Tertre and Joseph-Louis-Ripault Desormeaux's Histoire des conjurations, conspirations et revolutions célèbres, tant anciennes que modernes (1754-176o): "Now you have ended Maintenon you may perhaps think on it", Samuel Johnson to Charlotte Lennox, 10 March 1757, MS Eng 1269 (9), Houghton Library, Harvard University, reprinted in Schürer, Charlotte Lennox, 8o-81. She later decided to translate Guillaume Hyacinthe Bougeant's renown Histoire des guerres et des négociations qui precedent le traité de Westphale, sous le règne de Louis XIII et le ministère du cardinal Richilieu et du cardinal Mazarin (1727), Jean Racine's Bajazet (1672), and possibly write a "history of the (first) Elizabethan age" (Schürer, Charlotte Lennox, 100 n. 4).

73 Charlotte Lennox to [Samuel Richardson], 21 November 1751, TS 934.5, III, 296 (TSM 394.39), Harvard Theatre Collection, Houghton Library, Harvard University, reprinted in Schürer, Charlotte Lennox, 8-10. 
whose power over the copyright of her works had surely diminished, yet had not totally disappeared after the abolition of perpetual copyright. Lennox's last intercourse with James Dodsley may well serve as the proof of a relationship which by the time she had fallen out of the favour of patrons and sponsors, was once again literally reduced to one of charity, notwithstanding the success she had formerly achieved:

Sir

Having never settled accounts for the second edition of the Sister ${ }^{74}$ which you publishd [sic], I calld [sic] upon you with a hope that something might be due to me from that quarter - being realy [sic] at present in distress [...] Under my present difficulties, I have recourse to your candor, and humanity, that however small my claims may be [...], you will assist me with a trifling sum in my present necessities. [...] Some time hence, my circumstances will in all probability be much altered for the better, but I am now in real distress. $^{75}$

To this letter, Dodsley hastily replied that Lennox "could nevertheless have had no claim on me" on account of "any legal claims" she might exert on him, and bluntly treats her in the same manner as any irksome scribbler asking for consideration:

[...] as you represent yourself in distress, difficulties, and necessities, these have always a claim upon humanity. I am sorry this should be your situation, and therefore have inclosed a Note, and shall be glad if it prove acceptable. ${ }^{76}$

This transaction with Dodsley was probably the last Lennox entertained with the publishing world of London: her career had already started to eclipse during the 1770 s and the $178 \mathrm{os}$, after the failure of her periodical, when she

74 Lennox is here referring to her comedy The Sister, which Dodsley had published in two distinct editions in 1769 .

75 Charlotte Lennox to James Dodsley, 30 January 1793, MS Hyde 10 (413), Houghton Library, Harvard University, reprinted in Schürer, Charlotte Lennox, 214-16. Schürer also reminds us of how "poor Lennox really was", since "[w]ith an income of $£ 40$ per annum, [she] made more than a beadle (£2o p.a.) or a housekeeper (£28 p.a.) and about the same as a $\operatorname{cook}\left(£_{4}\right.$ o p.a.), but less than most hairdressers (£40-80 p.a. in London in 1797) or mantuamakers (£6o p.a. in London in 1797)", Schürer, Charlotte Lennox, 215 n. 5. See also Kirstin Olsen, Daily Life in 18th-Century England, Westport, CT, 1999, 140-45.

76 James Dodsley to Charlotte Lennox, 2 February 1793, MS Hyde 10 (191), Houghton Library, Harvard University, reprinted in Schürer, Charlotte Lennox, 217-18. 
only published one translation for Dodsley (Vallière, 1774), a comedy for Thomas Becket (Old City Manners, 1775), and her last novel Euphemia for Thomas Cadell (1790). Furthermore, her daughter had died, she separated from her husband, and her son, George Luis, emigrated to North America. She then turned to James Boswell, Samuel Johnson's official biographer, as to someone who could take on Johnson's role and "employ [his] elegant Pen for half an hour, in drawing up [her] Proposals".77 The proposal Boswell indeed wrote for a new subscription edition of Lennox's Shakespear Illustrated was intended to be dedicated to the Duchess of York, and according to Schürer, she also started selling subscriptions; ${ }^{78}$ however, the edition was never published, and this additional disappointment may further account for Lennox's disastrous reliance on a network of exclusively professional authors and sponsors, rather than social circles of just friends and readers from the gentry who might have shared the costs of publication. In short, her commitment to endorse an innovative position as an intellectual woman writer busy with professional literary enterprises had a high cost. With the decrease and ultimate failure of her direct, personal agency over the book market, she was not able to maintain the social status of married woman, mother and friend, as required from the society in which she lived. Lennox's parable from literary success to abject poverty was testimony to the impossibility to combine her writing ambitions and leadership potentials, which she channelled into a feverish, extraordinary literary production, with prescribed gender roles - which, under the constraints of economic imperatives she defied, but eventually surrendered to. She had been an outsider since her arrival in London: first as an orphan having to rely on relatives' wealth and support, then as the wife of a "most unnatural" man, and finally as a conscious, somehow "masculine" professional who aimed at living on her own commitment to literature and translation. Her position as outsider was also ostensible in the literary circles she mindfully chose not to frequent, most strikingly that of the Bluestockings. In the end, she also disappeared as an outsider, not having been inclined to find a compromise between her pioneering activity as a translator, periodical editor, and leader of several literary projects, and her compliance with the protocol and expectations of an author writing at a time when the economic nature of literature seemed to be still inappropriate for a woman writer, although she undoubtedly suffered all of its consequences.

77 Charlotte Lennox to James Boswell, 5 February 1793, GEN MSs 89 (Boswell Collection), series I, box 26, folder 614 (C1726), Beinecke Rare Books and Manuscript Library, Yale University, reprinted in Schürer, Charlotte Lennox, 219-20. 


\section{Bibliography}

\section{Primary References}

[Lennox, Charlotte]. 1747. Poems on Several Occasions: Written by a Young Lady. London: Paterson.

Lennox, Charlotte. 1750. The Life of Harriot Stuart. London: Payne and Bouquet.

Lennox, Charlotte [?]. 1751. Trans. The Memoirs of the Duke of Sully; During his Residence at the English Court; to which he was sent Ambassador from Henry IV. of France, upon the Accession of King James the First. London: Robert Dodsley.

Lennox, Charlotte. Trans. 1752a. The Age of Lewis XIV. Translated from the French of M. de Voltaire. London: R. Dodsley.

Lennox, Charlotte. 1752b. The Female Quixote. London: Millar.

Lennox, Charlotte. 1753-54. Shakespear Illustrated. London: Millar.

Lennox, Charlotte. 1756a. Trans. Memoirs of Maximilian de Bethune, Duke of Sully, Prime Minister to Henry the Great. Containing the History of the Life and Reign of that Monarch, And his own Administration under Him. Translated from the French, by the Author of the Female Quixote. To which is added, the Tryal of Ravaillac for the Murder of Henry the Great. In Five Volumes. London: Millar.

Lennox, Charlotte. 1756b. Trans. The Memoirs of the Countess of Berci. Taken from the French by the Author of the Female Quixote. In Two Volumes. London: Millar.

Lennox, Charlotte. 1757a. Trans. Memoirs for the History of Madame de Maintenon And of the Last Age. Translated from the French, by the Author of the Female Quixote. In Five Volumes. London: Printed for A. Millar, and J. Nourse [...], R. and J. Dodsley [...], L. Davis [...], and C. Reymer [...].

Lennox, Charlotte. 1757b. Philander: A Dramatic Pastoral. London: Millar.

Lennox, Charlotte. 1758. Henrietta. London: Millar.

Lennox, Charlotte. 1759. Trans. The Greek Theatre of Father Brumoy. London: Millar, Vaillant, Baldwin, Crowder, Johnston, Dodsley, and Wilson and Durham.

Lennox, Charlotte. 176o-61. The Lady's Museum. London: Newbery and Coote.

Lennox, Charlotte. 1762. Sophia. London: Fletcher.

Lennox, Charlotte. 1767. The History of Eliza. London: J. Dodsley.

Lennox, Charlotte. 1769. The Sister: A Comedy. London: J. Dodsley.

Lennox, Charlotte. 1774. Trans. Meditations and Penitential Prayers, Written by The celebrated Dutchess de la Vallière, Mistress of Lewis the Fourteenth of France. After her Recovery from a dangerous Illness, when she first formed the Resolution of quitting the Court, and devoting herself to a Religious Life. Translated from the French. With some Account of her Life and Character, extracted from Voltaire, Sevigné, and other Writers of that Time. By Mrs. Charlotte Lennox. London: Printed for J. Dodsley. 
Lennox, Charlotte. 1775. Old City Manners. A comedy. Altered from the original Eastward Hoe, written by Ben Jonson, Chapman, and Marston. By Mrs Lennox. As it is performed at the Theatre-Royal, in Drury Lane. London: T. Becket.

Lennox, Charlotte. 179o. Euphemia. London: Cadell and Evans.

\section{Secondary References}

Adam, Wolfgang. 2010. 'La Italienische Biographie di Johann Georg Meusel' in G. Cantarutti, S. Ferrari, and P.M. Filippi (eds) Traduzioni e Traduttori del Neoclassicismo. Milan: FrancoAngeli: 23-34.

Adburgham, Alison. 1972. Women in Print: Writing Women and Women's Magazines from the Restoration to the Accession of Victoria. London: Allen \& Unwin.

Agorni, Mirella. 1998. 'The Voice of the 'Translatress,' from Aphra Behn to Elizabeth Carter' in Yearbook of English Studies 28: 181-95.

Agorni, Mirella. 2002. Translating Italy for the Eighteenth Century: British Women, Translation and Travel Writing. Manchester: St. Jerome.

Agorni, Mirella. 2005. 'A Marginal(ized) Perspective on Translation History: Women and Translation in the Eighteenth Century' in Meta: Journal des Traducteurs 5०(3): 817-3o.

Anon. 1756. 'Review [of Charlotte Lennox's translation of Berci]' in The Critical Review: or, Annals of Literature. By a Society of Gentlemen. London: Printed for R. Baldwin.

Bataille, Robert R. 200o. The Writing Life of Hugh Kelly: Politics, Journalism, and Theater in Late Eighteenth-Century London. Carbondale: Southern Illinois University.

Beasley, Jerry C. 1985. 'Charlotte Lennox' in Martin C. Battesin (ed.) British Novelists, 166o-180o. Detroit: Gale: 306-12.

Berg, Temma. 2006. The lives and letters of an eighteenth-century circle of acquaintance. Aldershot and Burlington, VT: Ashgate.

Boulard Jouslin, Claire. 2012. 'Conservative or Reformer? The History and Fortune of Fénelon's Traité de l'Éducation des filles in Eighteenth-Century England' in The Journal for Early Modern Cultural Studies 12(4): 48-77.

Brack, O.M. Jr. (ed.). Hawkins, Sir John. 20o9. The Life of Johnson, LL.D.. Athens and London: The University of Georgia Press.

Brack, O.M. Jr. and Susan Carlile. 2003. 'Samuel Johnson's Contributions to Charlotte Lennox's The Female Quixote' in Yale University Library Gazette 77: 166-73.

Brewer, John and Ann Bermingham (eds). 1995. The Consumption of Culture 1660180o: Image, Object, Text. London: Routledge.

Brown, Sarah Annes. 2005. 'Women Translators' in Stuart Gillespie and David Hopkins (eds) The Oxford History of Literary Translation in English. Oxford: Oxford University Press: III, 111-2O. 
Carlile, Susan. 2004. 'Charlotte Lennox's Birth Date and Place' in Notes \& Queries $5^{1}(4): 390-92$.

Carlile, Susan (ed.). 2011. Masters of the Marketplace: British Women Novelists of the 1750s. Bethlehem, PA: Lehigh University Press.

Carlile, Susan (ed.). 2018. Charlotte Lennox. An Independent Mind. Toronto: University of Toronto Press.

Clarke, Norma. 200o. Dr Johnson's Women. London: Pimlico.

Climenson, Emily J. (ed.). 19o6. Elizabeth Montagu. The Queen of the Blue-Stockings. Her Correspondence from 1720 to 1761. 2 vols. London: John Murray.

De Castries, René. 1986. La Scandaleuse Madame de Tencin (1682-1749). Paris: Perrin.

D’Ezio, Marianna. 2011. 'Introduction' in Claudine Alexandrine Guérin de Tencin, The History of the Count de Comminge, translated by Charlotte Lennox. Newcastle upon Tyne: Cambridge Scholars Publishing.

Fleeman, John David. 20oo. A Bibliography of the Works of Samuel Johnson. 2 vols. Oxford: Clarendon Press.

Gallagher, Catherine. 1994. Nobody's Story. The Vanishing Acts of Women Writers in the Marketplace, 1670-1820. Berkeley and Los Angeles: University of California Press.

Galli Mastrodonato, Paola. 20o9. Storia della vita e tragica morte di Bianca Capello: genesi di un racconto di successo del Settecento. Florence: Nicomp.

Gottsched, Johann Christoph, Luise Gottsched, and Dorothea von Runckel (trans.). 1757-61. Nachrichten, die zum Leben der Frau von Maintenon und des vorigen Jahrhunderts gehörig sind. 3 vols. Berlin and Stettin: Rüdiger.

Gray, James. 1985. 'Dr Johnson, Charlotte Lennox, and the Englishing of Father Brumoy' in Modern Philology 83: 142-5o.

Griffin, Dustin. 1996. Literary Patronage in England, 1650-180o. Cambridge: Cambridge University Press.

Grundy, Isobel. 2000. '(Re)discovering women's texts' in Vivien Jones (ed.) Women and literature in Britain 1700-1800. Cambridge: Cambridge University Press: 179-96.

Hazen, Allen. 1937. Samuel Johnson's Prefaces and Dedications. New Haven: Yale University Press.

Isles, Duncan. 1970-71. 'The Lennox Collection' in Harvard Library Bulletin 18(4): 31744; 19(1): 36-6o; 19(2): 165-86; 19(4): 416-35.

Krontikis, Tina. 1992. Oppositional Voices: Women as Writers and Translators of Literature in the English Renaissance. London: Routledge.

Lorenzo Modia, María Jesús. 2010. 'Education for Women in the Eighteenth-Century Periodical: Charlotte Lennox's The Lady's Museum' in A. Antón-Pacheco, I. Durán Giménez-Rico, C. Méndez García, J. Neff van Aertselaer, and A.L. Rodriguez Redondo (eds) Diferencia, (des)igualdad y justicia / Differences, (In)Equality and Justice. Madrid: Fundamentos: 201-12. 
McMurran, Mary Helen. 200o. 'Taking Liberties: Translation and the Development of the Eighteenth-Century Novel' in The Translator 6: 87-108.

McMurran, Mary Helen. 2010. The Spread of Novels. Translation and Prose Fiction in the Eighteenth Century. Princeton and Oxford: Princeton University Press.

Olsen, Kirstin. 1999. Daily Life in 18th-Century England. Westport, CT: Greenwood Press.

Pieretti, Marie-Pascale. 2002. 'Women Writers and Translation in Eighteenth-Century France' in The French Review 75(3): 474-88.

Pitcher, E.W. 1976. “Charlotte Ramsay Lennox's 'History of Bianca Capello (1760)” in American Notes \& Queries: 130-31.

Portela, Manuel. 2004. Writing for Money, or The Distresses of a Hired Writer. Unpublished lecture notes. Universitade de Trás-os-Montes e Alto Duro.

Powell, Manushag N. 2012. Performing Authorship in Eighteenth-Century Periodicals. Lewisburg: Bucknell University Press.

Raven, James. 2007. The Business of Books: Booksellers and the English Book Trade. New Haven and London: Yale University Press.

Rose, Mark. 1993. Authors and Owners: The Invention of Copyright. Cambridge, MA and London: Harvard University Press.

Schellenberg, Betty A. 2005. The Professionalization of Women Writers in EighteenthCentury Britain. Cambridge: Cambridge University Press.

Schofield, Mary Anne and Cecilia Macheski (eds). 1986. Fetter'd or Free? British Women Novelists, 1670-1815. Athens: Ohio University Press.

Schürer, Norbert. 2001. 'A New Novel by Charlotte Lennox' in Notes \& Queries n.s. 48(4): 419-22.

Schürer, Norbert (ed.). 2012. Charlotte Lennox. Correspondence and Miscellaneous Documents. Lewisburg: Bucknell University Press.

Séjourné, Philippe. 1967. The Mystery of Charlotte Lennox, First Novelist of Colonial America (1727-1804). Aix-en-Provence: Publications des Annales de la Faculté des Lettres.

Shōji, Yamada. 2012. "Pirate" Publishing. The Battle over Perpetual Copyright in Eighteenth-Century Britain. Kyoto: Nichinbunken.

Small, Miriam Rossiter. 1935. Charlotte Ramsay Lennox: An Eighteenth-Century Woman of Letters. New Haven: Yale University Press.

Thomson, Ann and Sasha Roberts (eds). 1997. Women Reading Shakespeare 1660-19oo. An anthology of criticism. Manchester: Manchester University Press.

Todd, Janet. 1989. The Sign of Angellica. Women, Writing and Fiction, 1660-180o. New York: Columbia University Press.

Trulli, Maristella. 2010. 'La traduzione tra trasgressione e formazione: Charlotte Lennox e le altre' in Oriana Palusci (ed.) Traduttrici. Questioni di gender nelle letterature di lingua inglese. Naples: Liguori: 61-71. 
Turner, Cheryl. 1992. Living by the Pen. Women Writers in the Eighteenth Century. London and New York: Routledge.

Venuti, Lawrence. 2000. 'Neoclassicism and Enlightenment' in Peter France (ed.) The Oxford Guide to Literature in English Translation. Oxford: Oxford University Press: 55-64.

Vogler, Fredrick W. 1996. 'Vital d'Audiguier and Charlotte Lennox: Baroque Studies, Women's Studies, and Literary Resurrection' in Romance Notes 36(3): 293-99. 


\title{
Beating the Odds: Sophie Albrecht (1756-1840), a Successful Woman Writer and Publisher in Eighteenth-Century Germany
}

\author{
Berit C.R. Royer
}

The example of the German writer, editor, publisher and actress Sophie Albrecht provides noteworthy insights into female commercial authorship in the late eighteenth century. Considering her family background and early education, her subsequent career choices and her achievements in networking with like-minded representatives of the German cultural scene, it becomes clear that she stood a good chance of becoming a successful professional writer. Albrecht fought for the recognition of a small literate, and even smaller literary audience in rivalry with male colleagues. Despite inequality, Albrecht succeeded in this artistic as well as entrepreneurial challenge, and even occasionally outperformed idolised contemporary male writers, such as Schiller. Her example demonstrates the ways in which gendering processes worked in favour of male cultural achievements from the very beginnings of media history, and how reception history has solidified this.

The late eighteenth-century German writer, editor, publisher and actress, Sophie Albrecht, was born at a time when the role of women was reduced to their function in the family. Albrecht beat the odds against succeeding as a writer by launching a dual professional career in commercial authorship and professional acting during the 1780 os. Specifics on how she entered the literary market, her professional and entrepreneurial qualities in dealing with advertising and publishing networks, provide insights into her progressing literary and financial accomplishments. In contrast to this initial success, she also experienced setbacks and financial hardship later on in life. Albrecht received enormous attention during her early career, but was practically forgotten by 
the second half of the nineteenth century. It was not until the late 1970s, when the new wave of feminism began drawing attention to the "disappeared" German women writers of the past that she became of interest again. Feminist scholars started academic study of Albrecht's work in the late 1980 os and since then, scholarly attention to her oeuvre has rapidly intensified. ${ }^{1}$

This chapter presents detailed background to Albrecht's familial origins and education, her strategies to a successful career path in publishing and life as a celebrated author. In many ways, she overcame societal and gendered asymmetry in eighteenth century Germany and even exceeded the professional preconditions of the expanding German book market.

\section{Biographical Clues for a Unique Career as a Writer}

Despite the fact that Sophie Albrecht has now found her place in German literary studies, verifiable evidence surrounding her birth remains scarce. ${ }^{2}$ The first known piece of information is a baptism date entry from 6 December 1756 in the Baptismal Register of St. Bonifatius Church in Sömmerda, Thuringia. It was customary then to baptise children three days after birth, so a possible birthdate can be deduced. ${ }^{3}$ The register shows that Albrecht was born into a privileged, highly educated and intellectually outstanding family with sensitivities towards the Enlightenment movement. Johanna Sophia Dorothea Baumer was the eldest daughter of Rebecca Johanna Maria Christina Baumer (?- †1782), née

1 For a comprehensive overview of feminist research done on Albrecht during the past 39 years, see: Berit C.R. Royer, "Sophie Albrecht, ein künstlerisches Phänomen in Literatur und Theater des 18. Jahrhunderts - Gender, Rezeption und die Arbeitsgemeinschaft mit ihrem Ehemann", in Verehrt. Verflucht. Vergessen. Leben und Werk von Sophie Albrecht und Johann Friedrich Ernst Albrecht ed. Rüdiger Schütt, Hannover 2015, 314-21.

2 The following biographical information is in addition to: Berit C.R. Royer, Sophie Albrecht (1757-1840) im Kreis der Schriftstellerinnen um 1800: eine literatur- und kulturwissenschaftliche Werk-Monographie, Diss. UCD, Ann Arbor 1999, 30-102; Berit C.R. Royer, "Die Literatur der Schriftstellerin Sophie Albrecht (1757-1840) und ihrer Erfurter Kolleginnen als frühfeministischer und literaturgeschichtlicher Beitrag zur 'Dalbergzeit' (1772-1802)", in Aufklärung in der 'Dalbergzeit' ed Michael Ludscheidt, Erfurt 2006; and Royer, "Sophie Albrecht, ein künstlerisches Phänomen".

3 Verification in form of a birth certificate cannot be obtained. Entry in the Baptismal Register. "Father: Johann Paul Baumer, Medical Doctor here. Mother: Rebecca Johanna Maria Christina, née Tüntzel from Tuntzenhausen. 1. Godmother: Chamber Master's wife Johanna Sophia, widowed Jackelius, in Zeitz; 2. Godmother: Anna Maria Dorothea Tüntzel, wife of Georg Tüntzeles, lord of the manor, and judiciary in Tuntzenhausen." [This and all subsequent translations are by me, $\mathrm{BCR}$ ]. 
Tüntzel von Tunzenhausen and Johann Paul Baumer (1725-1771). ${ }^{4}$ Her mother came from the noble family of Tüntzel whose origins can be traced back to the Electorate of Saxony. During the seventeenth century, Gabriel Tüntzel, a solicitor, Count Palatine and Elector of Privy, was one of their most recognised family members. ${ }^{5}$ Exact information on family ties within this aristocratic family, and its affiliations with other noble families, are difficult to reconstruct. Nonetheless, aristocratic interconnections were partially responsible for Sophie Albrecht's privileged living and future working conditions. Henriette von Montenglaut was a friend and fellow writer, and she emphasised in her biographical sketch ${ }^{6}$ that Sophie's mother belonged to a "highly educated, old aristocratic family whose name never escaped her lips". ${ }^{7}$ Yet, little information was provided other than that Albrecht's mother was descended from noble origin and that she had been "her [daughter's] leader" in life. ${ }^{8}$

It makes it all the more remarkable that she chose a bourgeois husband, and intentionally descended the social scale in German feudalistic society. She disregarded the usual adherence to social status with an unacceptable marriage: this was in fact no small thing for a woman, who had no impact on her social position otherwise. She bravely left the privileged position she had been born into and married her love, Paul Baumer, a practising medical doctor in Sömmerda, very near Tunzenhausen. Baumer had studied medicine in Halle, Saxony, and received a doctorate at the University of Erfurt, Thuringia. The University of Halle was one of the centres (1694) for the reforming Enlightenment movement and provided credentials for an outstanding academic career.

4 Sömmerda belonged from the end of the thirteenth century to the imperial city of Erfurt, Thuringia, and thus to the Archbishopric of Mainz, Germany.

5 Johann Siebmacher, Wappen-Buch, Nürnberg 1701/05 and 1772, 143, suspected Meissen, Saxony, to be the place of origin for the family. Johann S. Müller, Des Chur- und Fürstlichen Hauses Sachsen, Ernestin- und Albertinischer Linien Annales von 140o - 1700, Leipzig 1700, 318, mentioned the presence of G. Tün[t]zel in 1621 among the "whole Electoral House of Saxony" at the Imperial Court in Vienna. See also: Adam Geisler, "Bruchstücke aus dem Leben der deutschen Dichterin Sophie Albrecht” in Gallerie edler teutscher Frauenzimmer, Bd.1, Heft 1, Dessau und Leipzig 1784, 142.

6 Henriette von Montenglaut, "Biographische Skizze der gewesenen Schauspielerin und noch immer still-wirkenden Dichterin Sophie Albrecht in Hamburg, nebst einer Aufforderung an die Deutsche Künstlerwelt", in Der Freimüthige, Berlin 1828. Source material is scarce about Sophie Albrecht, often not reliable but a few contemporaries are more trustworthy. For a list, see: Royer, "Sophie Albrecht, ein künstlerisches Phänomen", 227-28, footnote 51.

7 Montenglaut, "Biographische Skizze”, 958. "Ihre Mutter gehörte, nach Sophiens gegentlicher Erzählung, einem hoch gebildeten, alt adligen Geschlecht, an, dessen Name aber nie ihren Lippen entschlüpfte."

8 Geisler, "Bruchstücke", 15o, "ihre Leiterin". 
Although he initially began as resident doctor in 1749 in Sömmerda, he later moved his family to Erfurt to take up a professorship. In January 1765, Baumer became Professor of Medicine, and, in February, Associate Professor at the Faculty of Philosophy. ${ }^{9}$ He advanced further academically in 1767 , and was commended for his service to the university, ${ }^{10}$ as well as for his contributions to the reform of medical studies and for his various writings on the medical treatment of patients. As the younger brother of the eminent physician, Johann Wilhelm Baumer (1719-1788), who was also co-founder and first secretary of the 1754 founded "Churfürstlich-Mayntzischen Gesellschaft oder Akademie nützlicher Wissenschaften"11 in Erfurt, he had an influential position in society. Paul Baumer was also a member of that Academy, and additionally won the contest of the Prussian Academy of Sciences in Berlin tendered by Frederick the Great in 1764. As a professor at the Faculty of Philosophy, he would entertain literary interests with his famous relative, Christoph Martin Wieland, ${ }^{12}$ and had relationships with several other scholars of his time. The Baumer family had a significant influence in the academic elite and, through the noble origins of the wife and mother, Christina, certain privileges in aristocratic society. ${ }^{13}$

9 Information about J.P. Baumer and his famous brother Johann Wilhelm, see: Friedrich W. Strieder, Grundlage zu einer hessischen Gelehrten und Schriftsteller Geschichte, Bd.1, Göttingen 1781, 296; Michael Thiel, Albrecht, Arzt, medizinischer Volksschriftsteller, politische Belletristik, Berlin 1970.

10 Medicinische Biographie ed. August Brüggemann, Halberstadt 1829, 345 .

11 This Academy of Sciences is the third oldest academy in Germany, and among its most famous members were: J.C. Adelung, J.C. Gottsched, J.W. v. Goethe, A. \& W.v. Humboldt, J.G. Meusel, F.v. Schiller, C.M. Wieland. Chamber President of around 1785 was Karl von Dacheröden, father of Sophie's close friend Caroline von Dacheröden, later wife of W. v. Humboldt. See: J. Kiefer, Bio-bibliographisches Handbuch der Akademie Gemeinnütziger Wissenschaften zu Erfurt 1754-2004, Erfurt 2005.

12 There was a widely branched relationship between the Baumer and Wieland family: Sophie Albrecht's aunt Dorothea Wilhelmine Charlotte Baumer was married to the youngest brother of Wieland's mother Regina Catherine, the physician, Johann Joducus Kick (1726-1811), who resided in Hamburg. Wieland had been placed in 1749 as a student of philosophy in Erfurt at his professor's and Uncle's house, Johann Wilhelm Baumer. In 175o, he fell in love with his cousin Sophie Gutermann, who became the famous writer, Sophie von La Roche. Although they did not marry, they remained friends all their life. Wieland became the editor to La Roche's bestseller novel Geschichte des Fräuleins von Sternheim, and probably initiated contact with Sophie Albrecht. In 1769, Wieland was still a professor in Erfurt, but in 1772 he followed the call of Duchess Anna Amalia of Saxony-Weimar to take over the education of her sons. He remained as a Councilor in Weimar, even after the accession to the throne of Karl August. See among others: Wieland Briefwechsel, BW 20.1, Berlin 2007, 355; Peter-André Alt, Schiller, Bd.1, München 2009, 543; and Montenglaut, "Biographische Skizze", 958.

13 The importance of the connection to the large aristocratic Dalberg family is described in Royer, "Die Literatur". 
In addition, there were also noteworthy relations with bourgeois merchant families in Erfurt. This resulted in all respects in an exceptionally privileged family constellation, which promoted an unusual head start in life for Sophie Albrecht. The privileges of her origin shaped her upbringing and education, which later furthered her professional career.

\section{Education, Starting Point as a Writer, Editor and Publisher in the Baltic States}

At this point, it is useful to reflect on the education of the female population in Germany at that time in history. There was generally no formal education for girls, and the distribution of knowledge that the female population was permitted to receive in order to influence their position in society, was entirely supervised by senior family members. The lack of an established school system for girls' instruction, as well as enforced gender segregation resulted in low educational and, consequently, societal status for women. Although there was mention of a "Women's Academy" in the early Enlightenment movement - as was discussed, for example, in the moral weekly Der Patriot in $1724^{14}$ - there remained stiff resistance to academic or merely institutionalised education for girls for another 150 years. The university was then a gendered space and exclusively the domain of men..$^{15}$

In contrast to the ways of the broad, female population, Sophie Albrecht had experienced an unusually privileged upbringing, namely one in which books and intellectuals surrounded her. Paul Baumer's desired objective for his eldest daughter was to study medicine - just as the first female medical doctor in Germany, Dorothea Erxleben, who had graduated at his Alma mater. The study of medicine was accomplished at least in the initial stages: Albrecht's close friend, the writer, journalist and publisher, Adam Geisler, described her medical skills in wound care and bloodletting. ${ }^{16}$ Nonetheless, the exact extent of Albrecht's studies and instruction can only be speculated..$^{17}$ Montenglaut

14 Der Patriot, Nr. 3, 20.1.1724, Hamburg 1724.

15 Beatrix Niemeyer, "Ausschluss oder Ausgrenzung? Frauen im Umkreis der Universitäten im 18. Jahrhundert", in Geschichte der Mädchen- und Frauenbildung eds Claudia Opitz, Elke Kleinau, Band 1, Frankfurt/New York 1996.

16 Geisler, "Bruchstücke", 16o: "[...] wenn sie Dienste leisten kann, so ist sie gleichwol im Stande den übelriechensten Schaden zu verbinden" And: "Sie läßt sich selbst und mit eigener Hand zur Ader."

17 Since Sophie Albrecht's future husband, Johann, left a record of what he studied with his professor Paul Baumer, it is feasible that she received the same instructions in: "Physics, metaphysics, logic, anatomy, medicine, midwifery, semiotics, and attended private lectures 
noted her father's intention to stimulate her "rich genius" appropriately. ${ }^{18}$ It is verified that in addition to Albrecht's medical training, she received lessons in rhetoric, theology and modern languages. ${ }^{19}$ As an adult, she comprehensively studied philosophy: in 1784, she worked continuously on a draft of a "theory of soul", ${ }^{20}$ influenced by the Theosophy of Emanuel Swedenborg. Swedenborg's teaching had a substantial influence on Albrecht's later poetry production, especially on her love poems of the 178 os.

After Albrecht had suffered a traumatic brain injury during her early teenage years, her father opposed the study of medicine and advised a less strenuous academic routine for his daughter. Tragically all education came to a halt when Baumer died in September 1771. His sudden death resulted in several life changes: Albrecht was forced to take more responsibility in the household as the elder of the family's two daughters, and especially after her mother had gone blind. Nonetheless, she still managed to study literature ("Lektüre") on her own, and worked on her poetic talents ("dichterisches Talent") ${ }^{21}$ between the ages of 15 to 18 . Up to her father's death, instruction was restricted to academic learning only, and he had even placed a strict ban on her visiting the theatre. Albrecht first saw a professional theatre performance during her travels to Hamburg at the age of $19 .{ }^{22}$ This experience was likely a formative moment which influenced her career choices for the future. She later used her privileged education to subsequently search for and realise professional achievement in artistic, rather than academic fields.

This new stage of life initially started in collaboration with her husband, Johann Friedrich Ernst Albrecht. ${ }^{23}$ The starting point of their relationship was back in Albrecht's parents' house in Erfurt, when Johann began his medical studies at the local university. He became a lodger at his professor Paul

and internships." Compare: Franz-Ulrich Jestädt u. Thomas Kaminski, "Druck- und Verlagsgeschichte als Rekonstruktion eines Lebensfragments", in Schütt, Verehrt, 66-67.

18 Montenglaut, "Biographische Skizze", 958: “der Vater, [bemühte sich seiner] Tochter eine Erziehung zu geben, die [...] ihrem reichen Genie Gelegenheit gab, sich in den schönsten Blüthen zu entfalten [...]."

19 Geisler, "Bruchstücke", 143, mentioned toward Albrecht's rhetorical skills in childhood: "Sie war im Stande alles Gegenseitige zu verteidigen [...]." With regard to her modern language skills: she translated the song of Shakespeare's Desdemona, Othello, into: "Lied der Desdemona: Ein armes Mädchen saß und sang”, music by Franz Strohbach, Prague 1792. See:Jahrbuch der deutschen Shakespeare-Gesellschaft 37 (1901), 96. Compare: Geisler, "Bruchstücke", 158. He pointed out her manuscript of "Seelen-Lehre" for the year 1784 .

21 Ibid., 155.

22 Ibid., 163.

23 From this point referred to as 'Johann'. 


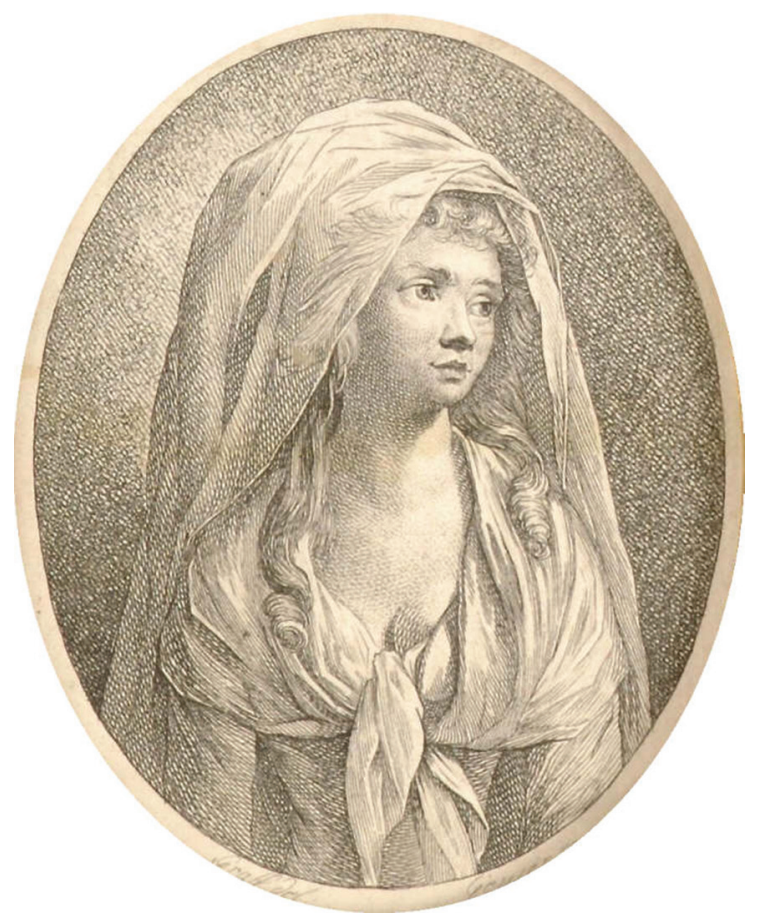

FIGURE 10.1 Sophie Albrecht. Christian Gottlieb Geyser, 1742-1803 SOURCE: WIKIMEDIA COMMONS (PUBLIC DOMAIN)

Baumer's residence in late March 1769; Sophie was twelve years old at the time and Johann almost seventeen. ${ }^{24}$ On 16 January 1772 , Johann received his doctorate in medicine and, on 16 June 1772, the two teenagers got married. The first of two children, their daughter Charlotte, was born almost exactly to the day nine months after their wedding ceremony; their son Wilhelm was born another 14 months later. ${ }^{25}$ Meanwhile, Johann lectured at the Faculty of Medicine and taught from the Summer term of 1772 up until 1776 in Erfurt. He then decided to become the personal physician of Count Karl Reinhold Manteuffel (1721-1779) in Estonia, and travelled with him within the Baltic countries, as well as Russia. It was just when the spouses were drawn to Tallinn that the joint interests of literature and theatre first resulted in literary publications.

24 Ibid., 152. Johann was born on 11 May 1752, in Stade near the northern German city of Hamburg.

25 Dorothea Johanna Charlotte Albrecht was born on 14 March 1773 [ $\dagger 13$ October 1839], and Carl Sigmund Wilhelm on 5 July 1774 [† 26 December 1845]. Compare Royer, "Sophie Albrecht, ein künstlerisches Phänomen", 322, footnote 32. 
By late 1778 , the Albrechts established their own publishing company, which marked their point of departure towards independent literary publications. ${ }^{26}$ The exact reasons for the founding of the publishing house "Albrecht und Compagnie" are not known. Nonetheless, some freelance writers during this period began to emancipate themselves from the old-established publishers for very good reasons: low honoraria and loss of intellectual property due to the absence of copyright laws were the most common drawbacks. Even famous writers such as Wieland grew tired of the old-established publishers' scams, and began with self-publishing. In fact, Albrecht's relative Wieland was a prime successful role-model for initiating self-publishing in Germany ever since the publication of his periodical Der Teutsche Merkur in 1773. In addition, the spread of literacy in Germany was the one crucial social development that helped further the reading experience since mid-century and make books accessible to a larger audience. Although the actual reading public in German speaking countries might have been as small as 2 per cent, ${ }^{27}$ the German book market was nevertheless rapidly expanding and a 'reading revolution' was well on its way. A combination of all of the above was likely convincing enough for the Albrechts to give the publishing business a try. ${ }^{28}$

The first publication by "Albrecht und Compagnie" was the almanac Ehstländische poetische Blumenlese ${ }^{29}$ in the beginning of the year 1779. Sophie Albrecht wrote a large number of poems for the almanac and the preliminary (iii-v) pages. The preliminary contains Albrecht's only known and surviving reflection on poetics: according to her, the essence of poetry draws its inspiration from something higher, spiritual, beyond our grasp. Though, without extensive reading and study, poetic genius could not manifest itself - this was in fact an important statement from a young poetess in favour of women's education. Albrecht also provided a total of 31 poems, more than half of all the

26 Although Johann's father was also an MD, it is noteworthy that his maternal grandmother Regina Elisabeth Kolbe, née von Stern (1692-1767), belonged to the von Stern family who founded their printing company in 1614 in Lüneburg, which happens to be Germany's oldest printing press still operating today in its fourteenth generation.

27 Figures for literacy among the German population (23 million) range between 1-2 per cent for the time frame; among them mainly aristocrats, clerics, and the upper-middleclass. The poet Jean Paul estimated the literary audience to around 30o,ooo readers.

28 These reasons were not only sufficient for Wieland and Klopstock but also for the founding fathers of the "Buchhandlung der Gelehrten" in Dessau (1781-85), which is yet another prime example for this development among writers.

29 Ehstländische poetische Blumenlese für das Jahr 1779, eds Albrecht, J.F.E. und Sophie, Wesenberg 1779. And one year later: Estländische poetische Blumenlese für das Jahr 1780, eds Albrecht, J.F.E. und Sophie, Leipzig u. Reval 1780. Spelling of the titles for the Estonian Almanac of Poetry are different in 1779 and 178 o. 
contributions to this first issue of the Estonian almanac of poetry. It contains eighteen orthonyme poems, ${ }^{30}$ and was the first major public platform for her as a young writer, and most likely just a trial balloon. Albrecht's husband Johann was merely responsible for organisational or commercial supply to the first edition of the Estonian almanac in 1779, since no orthonyme contribution of his can be traced. The contemporary journalist and critic A.B. Moskwa, who wrote an article about publishing companies in Allgemeine Literatur-Zeitung $1788^{31}$ looked at Sophie Albrecht retrospectively as the sole editor of the Estonian almanacs.

Noteworthy is the lyrical forerunner "Romanze" to Sophie Albrecht's most noted piece of literature by feminist reception so far, the drama Theresgen ${ }^{32}$ from 1781. The poem "Romanze"33 was anonymously published and already displays Albrecht's critical scepticism toward the patriarchal institution of marriage. This is particularly remarkable within the context of contemporary gender debates, and proves her early sympathy to radical politics that challenged the established order. Albrecht's poems include themes of love, friendship, ${ }^{34}$ of loss, and the longing for death, ${ }^{35}$ and therefore represent in their unconventional social criticism an unparalleled literary expression in late eighteenth-century Germany. ${ }^{36}$ Feminist and gender-oriented readings of Albrecht for the past 39 years unanimously support the view that her depiction of passionate hetero- and homoerotic love from a female perspective in poetry and prose make her unique for the period. The scandal caused by Albrecht's critical poetry within the established societal and gendered order of the time is perhaps beyond our grasp today. Therefore, excerpts from contemporary review periodicals of 1779 onwards might have a sobering effect. ${ }^{37}$

Review journals provided the reader with guidance to the multitude of new publications and magazines, and were continued in the tradition of scholars'

30 For another six poems she used several pseudonyms; seven more poems attributed to her are listed as anonymous.

31 Allgemeine Literatur-Zeitung, No. 155, Jena u. Leipzig 1788, 28 June, 719. ALZ was incidentally the competing review journal to the $A D B$.

32 For a comprehensive overview of feminist research on Albrecht's drama Theresgen see: Royer, "Sophie Albrecht, ein künstlerisches Phänomen", 316-18, footnotes 5-16.

33 Ehstländische poetische Blumenlese, 78-88.

34 Berit C.R. Royer, "Begleittext", in Bunte Kinder schwarzer Nacht, Brussels 1997.

35 Berit C.R. Royer, "Einführung", in Vorwärts, vorwärts sehn' ich mich, Brussels 2001.

36 Royer, Sophie, 103-79, for an overview of Albrecht's poem production with an introduction to poetry by German women around 1800 .

37 For an extensive overview of reception history with a large number of excerpt quotes from contemporary periodicals see: Royer, "Sophie Albrecht, ein künstlerisches Phänomen", from page 327 onwards. 
journals. There were review contributions to publications by women, but admittedly women were usually viewed neither as learned individuals, nor as public figures. Moreover, exclusively male reviewers provided review contributions to such journals and, implicit gendering strategies must be regarded as a correction to women leaving their designated gender roles.

Nonetheless, Johann Christoph Adelung, a member of the Academy of Sciences that Albrecht's uncle, Wilhelm Baumer, had founded in Erfurt, praised her poetry in Allgemeines Verzeichniß Neuer Bücher. ${ }^{38}$ It is possible that Sophie Albrecht used her family network to make herself known within the cultural scene and publishing business. This strategy seems all the more convincing since reviewers, who often wrote anonymously in "the most important review organ of the late German Enlightenment movement (1765-1806)",39 the Allgemeine Deutsche Bibliothek, habitually criticised almost all works, but especially those written by women. In this case, a certain "Mpr" saw in Sophie Albrecht's poem "An den Tod" (To Death) a lyrical expression that "appeared tolerable" in the Estonian almanac. ${ }^{40}$ At the same time, he ridiculed her poem "An meine Freundin T." (To My Girlfriend T.) in a sarcastic fashion. Albrecht parried "Mpr.s Sticheleyen" (Mpr's taunts) in the postscript to the next almanac as follows: "As far as the whimsical assessment in the Allgemeine Deutsche Bibliothek is concerned, it looks too much like a lampoon as to get worked up about it."41 Presumably, she took the review as slander as it was the only time that she commented on critics at all.

For the second edition to the Estonian almanac of 1780, the Albrechts acquired the privileges for the "Calendarium" (Russia) by Catherine the Great, whose silhouette is prefixed to this volume. The couple might have even met her personally during one of their alleged journeys to Saint Petersburg. ${ }^{42}$

38 J.C. Adelung, Allgemeines Verzeichniß Neuer Bücher: mit kurzen Anmerkungen, Leipzig 1779/80, 685; About EB, 1779 \& 1780: "Wenn man auch in diesen Sammlungen nicht die Namen der ersten deutschen Dichter findet, so enthalten sie doch viele gute Stücke unter welche die von Sophie Albrecht besonders genannt zu werden verdienen."

Helga Brandes, "Buch und Zeitschriftenmarkt, Frauenzimmer-Journale und Literaturkritik im 18. Jahrhundert”, in Zeitdiskurse, Reflexionen zum 19. und 20. Jahrhundert als Festschrift für Wulf Wülfing eds Roland Berbig, Martina Lauster and Rolf Parr, Heidelberg 2004, 314 .

40 Compare: $A D B$, Bd.37, Reviewer “Mpr., Berlin u. Stettin 1779, 485-88.

41 Estländische poetische Blumenlese, 166: "Was die schnurrige Beurtheilung in der allgemeinen deutschen Bibliothek betrifft, so sieht sie einem Pasquill zu ähnlich, als daß man sich überhaupt darüber einlassen könnte."

Commercial interests must have been predominant for acquiring the calendar privileges since no other reasons are otherwise comprehensible for catering to Catherine the Great's interests. Johann became one of her harshest critics later on. The Albrechts had moved 
Calendar privileges had proven profitable economically, and were also extremely lucrative for the treasury of the respective country. ${ }^{43}$ The first almanac from 1779 had been sold for 12 groschen, and the second for eight, which was an inexpensive retail price. With an estimated limited edition of perhaps 150 sold copies each, the revenue for both almanacs could not have been great. ${ }^{44}$ Presumably, the net profit for sold copies was about half the purchase price. ${ }^{45}$ The business strategy used to increase the profit margin for the second almanac edition through the acquisition of the calendar privileges was therefore a clever move: the going profit rate for calendar privileges was about 400 Gulden or 266 imperial thaler per edition. The second almanac sold for 8 groschen and could have fetched them a net income of 25 imperial thaler (plus 266 thaler on calendar privileges) to a total of 291 thaler. The first almanac edition might have only earned them 37 thaler. ${ }^{46}$ Considering that a lower middle-class family averaged a yearly income between 200 to 500 imperial thaler ${ }^{47}$ at the time, an estimated net profit of perhaps 328 imperial thaler for both almanacs is a tight profit margin, and averages to only 164 thaler per annum. However, the trial stage for Albrecht's enterprise is paramount for this early publication phase, since there was evidently little need for an income, as Johann received a salary for his family as personal physician.

This second Estonian almanac from 1780 contained Albrecht's poem "Als ich ihn erwartete" (When I was Waiting for my Lover), which was later plagiarised by Friedrich Schiller in $17966^{48}$ Although Schiller's poem was

their publishing business during the year 1779 from Wesenberg (Rakvere) to Reval (Tallinn), Estonia.

43 Werner Faulstich, Die bürgerliche Mediengesellschaft, Göttingen 2002, 151 .

44 For pricing see: Adelung, Allgemeines Verzeichni $\beta$, Neuer Bücher 685, entries 1196 and 1197, for each edition. According to contemporary currency conversion: 21 groschen were worth one thaler; 24 groschen averaged an imperial thaler (Reichstaler). I will elaborate on estimates for the purchasing power of old currencies in connection with Albrecht's two volumes of poetry below. On the topic of old German currency conversions, see: Helmut Kahnt, Bernd Knorr, Alte Maße, Münzen und Gewichte, ein Lexikon, Mannheim 1986.

45 Reinhard Wittmann, Geschichte des deutschen Buchhandels, München 1991, 151. Wittmann refers to the customary calculation of expenditures or rather profits into ird for honoraria, 1rd for production costs, and ird for distribution. Since the Albrechts were mainly responsible for distribution, and for very limited author honoraria, their net profit might have been as high as half the purchase price.

46 Both editions of the Estonian almanac were cheaply made, and all the copies I have seen personally were flawed with incorrect pagination, a few pages and text missing inconsistently here and there.

47 A servant had an annual income of only 1 imperial thaler during that period.

48 It was subsequently canonised as Schiller's poem "Die Erwartung" (Expectation). See: Royer, Sophie, 16o. The canonisation process is additionally demonstrated by musical settings 
clumsier and exaggerated in comparison with the original, his version was handed down by literary tradition as German canonisation worked almost exclusively in favour of male cultural achievements. Additional extensions to this second volume were Albrecht's short prose texts, and the musical settings: one of her poems "An sein Portrait" (To his Portrait) was set to music by the Erfurt-based musician, Peter Weimar. Later that year "Albrecht and Compagnie" published Lieder mit Clavierbegleitung (Songs with Piano Accompaniment), ${ }^{49}$ which contained a selection of six Sophie Albrecht poems, and was sold for 12 groschen.

Opinion-makers and their critique might have contributed to the fact that no other native Estonian poems were published in this volume. Aside from Johann Gottfried Herder, with his collection of folk songs Volkslieder, ${ }^{50}$ the Albrechts alone published native language Estonian songs in their otherwise exclusively German poem collection in this period. ${ }^{51}$ It also seems that decisive criticism against Sophie Albrecht as a poetess, though not made public in writing, had surfaced after the publication of the first Estonian almanac. ${ }^{52}$ However, a loyally inclined audience was still supportive of her for many years to come. During the short Baltic period, two overlapping groups of friends and supporters can be traced: the first consisted of dedicated middle-class men and women of letters, theatre lovers, active members of the Enlightenment movement, Freemasons and Illuminati; the second was comprised of the nobility, who often (but not exclusively) took part in the former groups and levelled

of Schiller's "Expectation" through famous musicians. Furthermore, by visual artists: one hundred years after Schiller's death, a series of postcards were published by the painter Emil Klein, 6 Bilder aus Schillers Leben, Stuttgart 1905 (Six Pictures from Schiller's Life). In it you will find an illustration for the "Expectation" which had been converted into the context of Schiller's life: there is the image of him on a garden bench, expecting the arrival of his future wife, Charlotte von Lengefeld. The original connection with Sophie Albrecht was completely gone by then.

49 Georg Peter Weimar, Lieder mit Clavierbegleitung, für Liebhaber eines leichten und fließenden Gesanges. Reval u. Leipzig 1780. "Dem Churtrierischen Kammerherrn Herrn Baron F.H. von Dalberg unterthänigst gewidmet von G.P. Weimar". By S. Albrecht: "An den Tod", 4-5, "Romanze", 6-7, "Verschwiegenheit", 8-9, "An den Schlaf", 12-13, "Die ersten Veilchen", 29, "Als ich ihn erwartete", 30-33. A number of poems by Albrecht were set to music in this period and later on.

50 Herder, Volkslieder, nebst untermischten andern Stücken, II, Leipzig 1779.

51 See also: Liina Lukas, "Estonian Folklore as a Source of Baltic-German Poetry", Journal of Baltic Studies, $42 / 4$ (2011), 496.

$5^{2}$ The introductory poem by Sembard (F.G. Arvelius) "to Sophia" allows that assessment. Perhaps one reason why Sophie Albrecht's first play was published anonymously: Lauschen ist auch gut ein Singspiel in zwey Aufzügen von einem Frauenzimmer. Reval u. Leipzig 1780. (Sheet music is missing.) 
out class differences. ${ }^{53}$ It is likely though that Albrecht's sympathetic reception among the aristocracy was also attributable to her mother's noble birth.

After the death of Count Manteuffel during the summer of 1779, Sophie and Johann Albrecht began their return to Erfurt, Thuringia. They handed over the remaining Estonian branch of their publishing business to a partner by the autumn of 1779 , and by early 1780 had devoted themselves to their next projects back in Germany. They had plans for more publications by different authors in their own publishing house "Albrecht und Compagnie", a bookstore, a lending library, and the publication of the periodical Erfurtische Gelehrte Zeitung. All these activities took place in the home of Sophie Albrecht in Erfurt, ${ }^{54}$ but which parts exactly were covered by which marital partner, cannot be reconstructed with certainty. It was said that Sophie Albrecht was responsible for the editing of Johann's texts. ${ }^{55}$ However, it is unknown if she was also involved in "Albrecht und Compagnie's" publisher program of yet another 39 publications between 1779 and 1786 . The fact that she had her share in the management of the bookstore in Erfurt enabled the distribution of Sophie von La Roche's almanac Pomona, and the PostScript in the letter that the editor wrote to Albrecht in 1786. La Roche had asked her there for the belated payment of a sum of money. ${ }^{56}$

\section{Departure for Independent Publications, Advertisements and Networks}

Sophie Albrecht's next career move toward independent publications for her own two volumes of poetry from 1781 and 1785 is remarkable. In fact, her publication activity became independent from her husband and also from the publishing house "Albrecht und Company". She took over the marketing for

53 This information can be extracted from the analysis of Albrecht's occasional poems in her almanacs, and from analysing lists of subscribers of the two volumes of poetry from 1781 and 1785 .

54 See: Helga Brück, "Sophie Albrecht, Schauspielerin und Dichterin (1757-1840)", in Reihe Bemerkenswerte Erfurter (VII), Thüringer Allgemeine Zeitung, Erfurt 1994.

55 Montenglaut, "Biographische Skizze", 962. This article contains, although deliberately defamiliarised and anonymised, many correct biographical details about S. Albrecht. Unfortunately, only this alienated version is obtained. Accurate information is to be located in a hitherto lost letter from Montenglaut to the Chamberlain and "Legationsrat" Jakob Ignaz von Cruickshank, as she wrote to Goethe in her letter from 9 February 1828 . See letter: Brief GSA 28/128-Weimar.

56 See: Royer, Sophie, letter appendix/Briefanhang, 366. 
the two upcoming volumes of poetry by disengaging from the joint venture with the publishing company. Whereas before, she had published her work by "Albrecht und Compagnie", as for example with her "Singspiel", a popular form of light opera, Lauschen ist auch gut from 1780, now, she just commissioned ("in Commißion") the company to provide distribution for the upcoming volumes. The reasons for this new business strategy are unknown, and can only be speculated: perhaps, she wanted to secure the sole copyright of her intellectual property by untying her own publications from the company, and/or she simply wanted to be financially in charge of her own book projects.

Having said that, since the beginning of the year 1781 , she had prepared the first orthonyme publication of her book of poetry and drama Gedichte und Schauspiele. ${ }^{57}$ Aside from the two dramas, it contained three prose texts and 73 poems ${ }^{58}$ with the aforementioned critical content. She had dedicated her first volume to her Tallinn-based friend, Dorothea Tideböhl, née Kelch. Albrecht advertised for this issue by mid-1781 in periodicals, such as the Gothaische Gelehrte Zeitungen, ${ }^{59}$ Berichte der allgemeinen Buchhandlung der Gelehrten, ${ }^{60}$ as well as in Wieland's Der teutsche Merkur, ${ }^{61}$ among others. The announcement in the German Mercury was a smart move on her part, because it had more than 2000 subscribers ${ }^{62}$ and was promising, with respect to public attention for her book project. In the ad, she elaborated on information about content and prices for early subscription (called "Praenumeration"), later prices at bookstores (referred to as "Commission"), and postal delivery costs. The best deal for purchase was early subscription with advanced payment of 20

57 Sophie Albrecht, Gedichte und Schauspiele, Erfurt 1781.

$5^{8}$ Some poems and short prose texts from the Estonian almanacs were published here again, but most are first editions.

59 Gothaische Gelehrte Zeitungen auf das Jahr 1781, 49 (20 June 1781), Gotha 1781, 408: “[...] Der Termin der Pränumeration, die hier die Ettingersche Buchhandlung annimmt, steht bis den isten Sept. d. J. offen."

6o Berichte der allgemeinen Buchhandlung der Gelehrten vom Jahre 1781, Dessau und Leipzig 1781,5 og.

61 "Über Gedichte und Schauspiele von Mad. Albrecht", in Der teutsche Merkur, ed. Wieland, Weimar 1781, 286-87. An announcement written by herself: "Für diesen Band soll der Pränumerationspreis zwanzig Groschen, den alten Louisd'or zu fünf Thaler gerechnet, seyn. Der Termin ist bis den September dieses Jahr offen, nachher wird eine Buchhandlung es in Commißion bekommen, und für 1 Rthlr. 8 Gr. den Liebhabern überlassen. [...] Auf zehn Exemplare wird eins, und auf zwanzig die drey folgenden frey gegeben, und bis Leipzig, Frankfurt, Hamburg und Lübeck werden die Exemplare frey geliefert. Nähere Oerter genießen diesen Vortheil auch. Erfurt, den 1. Junius 1781."

62 Karin Stoll, Christoph Martin Wieland:Journalistik und Kritik, Bonn 1978, 58. 
groschen until 1 September 1781. Afterwards, the price for the book increased to 32 groschen (equal to 1 imperial thaler and 8 gr.). If 10 copies were prepurchased, one was given for free; for 20 copies, 3 were given for free. Postal delivery was included in the price for German cities as far as Leipzig, Frankfurt, Hamburg, and Lübeck; closer regions received the same deal. Albrecht also called for a favour from her "known and unknown friends" (both male and female), to hand out the advertisement, and to accept upfront payment for the early purchases. ${ }^{63}$

The ad in the German Mercury included her private mailing address, which she provided for forwarding the money from the "collection" and pick-up of presold copies. She promised to print the names of early subscribers in the respective volume of poetry, and she did. Her business acumen as a publishing woman did not miss its target: she managed to win many collectors, and she pre-sold the book 174 times with their help. She had a simple edition printed (bound in strong cardboard, a leather book spine and with plain endpapers) as well as a precious edition (bound in leather with pink, black and blue marbleised endpapers, bottle-green book sections and gold-embossed book spine). ${ }^{64}$ However, she noted no price difference between the two editions in her ads. The early subscriber rebate was 12 groschen per book, with the currency conversion of 24 groschen per imperial thaler. With the estimated circulation being 250 for this edition, ${ }^{65}$ and 174 pre-sold books, the approximate revenue was 5912 groschen, or about 246 imperial thaler. Less all costs of materials and services, such as engravings, paper, typesetting, printing, book binding, shipping and distribution possibly amounted again to a net profit of half of the total books sold to about 123 thaler. That can be regarded as a comfortable profit for a first, and entirely independently made book project. ${ }^{66}$

63 Albrecht called for in the ad at Wieland's DtM, German Mercury. Compare: "[I]hre bekannte und unbekannte Freunde und Freundinnen, sich, wenn es ihnen gefällig ist, dieser Sache gütigst zu unterziehen, diese Anzeige auszutheilen, und den Vorschuß darauf anzunehmen."

64 The University Library of Hamburg, Germany, has both editions in their rare book collection. Even the simple edition was not as cheaply made as the Estonian almanacs.

65 Estimate by: Royer, Sophie, 44.

66 As mentioned above, a plain middle-class family was able to manage a living with 2005 oo imperial thaler per year. A high official's income in that period, such as in court circles, amounted to around 1,00o imperial thaler annually. Thus, the winning margin for the publication could be located in the lower income area of a modest middle-class family. However, in 1832, Sophie Albrecht had to make do with only 42 thalers per year; this sum does not reflect steady inflation over 5 o years, and not even regional differences in currency exchange rates. It just shows that a person could survive with a lot less money. 
Key to the successful selling of copies was the effort of many women. ${ }^{67}$ They had taken over sales in up to 28 cities or towns. ${ }^{68}$ Ever since the publication of the Estonian almanacs, Albrecht's criticisms of gender roles, social order and class hierarchy were publicly known and, thereby, highlight the extent of her loyal and efficient network. This network consisted primarily of the middleclass, but also of aristocrats, which suggests classification of this circle of women in a politicised context. ${ }^{69}$ Barbara Evers determined through her research that, contrary to popular belief, the female readership sought the unusual and unconventional in poetry by women. ${ }^{70}$

Albrecht's ability to network with her loyal like-minded female friends made her pass on tasks for her publication project. Just as she herself promoted Sophie von La Roche distribution of the almanac Pomona through an ad in Erfurtisches Intelligenz-Blatt ${ }^{71}$ with the collection of praenumeration and money for pre-sold copies, or Friedrike von Kamiensky's volume of poetry and prose Meine Muse, ${ }^{72}$ Albrecht's friends supported her: the reciprocal nature of friendship helped her entrepreneurial prospects and empowered all women involved. The initiated discourses on femininity, subjectivity and identity models by Albrecht, were first echoed in her own network of friends, before they reached greater audiences. Women had otherwise no direct access to institutionalised forms of power and established politics, which makes an early

67 This entrepreneurial phenomenon was simultaneously observed with female editors of women's magazines. Compare: Ulrike Weckel, Zwischen Häuslichkeit und Öffentlichkeit, Die ersten deutschen Frauenzeitschriften im späten 18. Jahrhundert und ihr Publikum, Tübingen 1998, 596: "In bisher ungekannter Zahl traten sie unter ihrem Namen auf Subskriptionslisten in Erscheinung und ermöglichten durch ihre Abnahme immerhin mindestens acht Frauenjournalen weiblicher Herausgeber ein Erscheinen über ein bis zwei oder sogar mehr Jahre. [...] Aus einem Diskurs über Frauen und ihre »weibliche Bestimmung « wurde hier ein Diskurs von Frauen."

68 The analysis can be determined through early subscription lists for the book: it yielded a nearly 34 per cent stake of female buyers and an approximately 66 per cent stake of male buyers. As it appeared from this first volume though, it was mainly women who provided more buyers in a city or town. This can be deduced from the numerical order of a listed number of books sold to one woman. This numerical sequence of copies sold is missing in volume 2 due to the different marketing strategy: subscription instead of praenumeration.

69 An evaluation of this network for its early feminist potential is discussed in: Royer, Sophie, 44-50, and: Royer, "Sophie Albrecht, ein künstlerisches Phänomen", 33 o.

70 Barbara Evers, Frauenlyrik um 180o, Studien zu Gedichtbeiträgen in Almanachen und Taschenbüchern der Romantik und Biedermeierzeit, Diss. Bochum 1991, 12.

71 Compare: Erfurtisches Intelligenz-Blatt, Stück 46, Erfurt 1782, 354-55.

72 Albrecht's name on subscription list to Friederike von Kamiensky, Meine Muse, Naumburg 1786, XI. 
feminist interpretation for this networking circle of women writers around Albrecht feasible. This observation must be perceived in the context of bourgeois emancipation, and the democracy movement in the run-up to the French Revolution.

It is not known what Johann thought about his wife's independent business venture, her literary works, her criticisms of gender roles, social order, and about her circle of loyal friends. In any event, he worked for her continuously, at least on an organisational level. However, the public attention she received by some review journals and the overall reception of her literary work, which was entirely in masculine hand, was divided..$^{73}$

Albrecht's literary work following her drama and poetry from 1781 was the first of her three-volume novel Aramena, a Syrian story, ${ }^{74}$ which was published at Georg Jacob Decker's in Berlin between 1782 and 1786. Novels have traditionally sold better than poetry, and presumably the publisher was hoping for guaranteed success by the already well-known writer. He sold the three-volume, elaborately leather-bound novel, for two thalers and 12 groschen. ${ }^{75}$ However, honoraria (and/or royalties), circulation figures and subsequent literary success for this novel are unfortunately unknown. ${ }^{76}$ Albrecht's friend and colleague at the Saxon Court Theatre, the director, Friedrich Reinecke, praised the novel and made reference to positive reviews in periodicals. ${ }^{77}$ The anonymous reviewers in the Allgemeine Deutsche Bibliothek of 1783 and $1788,{ }^{78}$ though, harshly criticised the novel (as already expected from this periodical). Whether this was a fair assessment or not is impossible to reconstruct. Nonetheless, it appears that Albrecht's critical poetry and drama was read and preferred by her loyal audience.

73 For more background on the couple's entrepreneurial partnership as well as excerpts from reception in review magazines, see: Royer, "Sophie Albrecht, ein künstlerisches Phänomen", 330-331.

74 Aramena, eine syrische Geschichte, ganz für unsere Zeiten umgearbeitet von S. Albrecht, Berlin 1782-86.

75 For pricing see: Die deutschen Schriftstellerinnen des 19. Jahrhunderts, ed. Schindel, Bd. 1, Leipzig $1823,8-9$.

76 In 1773, Klopstock received 12 thaler per paper sheet; see: Wittmann, Buchhandel, 146. One sheet held 16 printed pages. Computation for Aramena: 1782 Bd. I, 36o pages, 23 sheets; $1783 \mathrm{Bd}$. II, 38 o pages, 24 sheets; $1786 \mathrm{Bd}$. III, 336 pages, 21 sheets. If Albrecht had received as much as Klopstock per sheet, the estimated honoraria would have amounted to 816 thaler.

77 Johann Friedrich Reinecke, Biographien einiger deutschen Schauspielerinnen, Kopenhagen u. Leipzig 1787,17 .

78 Allgemeine Deutsche Bibliothek, Bd. 55, 2. St., Berlin u. Stettin 1783, 414-15, reviewer pseudonym "S"; Bd. 83, 1. St., Berlin u. Stettin 1788, 136-37, reviewer pseudonym "Zf". 
By the mid-eighties, Sophie Albrecht had acquired significant knowledge of the mechanisms of the cultural scene and the expanding book market. Ever since 1776 , she and her husband visited the Leipzig book fair annually, to either present their own new publications, or to network with other writers and publishers.

Albrecht's second volume of poetry and prose essays, including "Fragmente aus dem Tagebuch einer Unglücklichen" (Fragments from the Diary of an Unfortunate Woman) from 1785 was again an independent made publication. Once more "Albrecht und Compagnie" just acted as distributor for her book, and she simply commissioned the company to provide that service ("in Kommißion", that is, Commission). ${ }^{79}$ She therefore kept all copyright privileges as an author for herself, and was solely responsible for the financing. The new edition of poetry and short prose was announced by Sophie Albrecht in 1784, and informed the reader anew about price advantages for early subscribers. However, just "Subscription" was invited this time, not in advance payments ("Praenumeration"). This second book was dedicated to her friend Antoinetten von Dalberg, Abbess of St. Mergen, Cologne, and sister of her benefactor, Karl Theodor von Dalberg. Albrecht advertised for her new book project in Journal von und für Deutschland, ${ }^{80}$ stating her personal forwarding mailing address in Mainz. The time for publication was the beginning of the Leipzig book fair in the spring of 1785 . The early subscription price was again 20 Saxon groschen, but the subsequent pricing for bookstores (Commission) was now at one gulden and 30 kreuzer (equal to one imperial thaler); the price advantage was only at four groschen. This is believed to be an indication of her achieved literary success, since the financial incentive for early subscription was eight groschen lower than before. It is likely that the success of her poetry was so great that it was no longer necessary to demand advance payment, or to offer a more profitable early subscription advantage. Again, she published both a simple and precious edition. This second volume of poetry was subscribed to by an additional 161 readers, which amounted altogether to 405 subscribed copies. An increase of about 60 per cent of buyers could be recorded, and also an extension to readers in other European countries. ${ }^{81}$ The gain in subscribed

79 As a matter of fact, only her two volumes from 1781 and 1785 were distributed by "Albrecht und Compagnie" (in Komißion), aside from the very last company publication during that period: Skizzen aus dem Klosterleben in 1786. Although I have not seen the book myself, it seems possible that Sophie was involved in it artistically as well.

8 o Journal von und für Deutschland, 1 (July-December 1784), 67, and "Supplement Register".

81 According to former state borders: Holland, Switzerland, Austria; according to present state borders, additionally: Poland, and the Czech Republic. 
copies was 231, and the proportion of bookstores and publishers as buyers had tripled. Having said that, the number of unnamed early subscribers had also increased by 73 persons for this volume to altogether 77 , and was therefore 95 per cent higher than in the first volume. That might have had something to do with the already known critical content of her poetry. With an estimated circulation of 500 copies $^{82}$ for this edition, less all expenses (of a little less than half an imperial thaler per book), this possibly resulted in a net profit of around 220 thaler. In summary, by the mid-178os, Sophie Albrecht had managed to secure a loyal readership for herself, and also achieved a handsome profit as a writer and publisher. ${ }^{83}$

The reviews of the second volume were correspondingly more numerous, more extensive, and appeared in a larger number of periodicals. Some reviewers praised her with exuberance, called her the German Sappho, and assessed her work even more favourably than Goethe's. ${ }^{84}$

\section{The Theatre Stage as a Multimedia Extension for the Literary Career}

The transition to Sophie Albrecht's additional career as an actress had already begun in 1783 . She had launched her dual professional career in commercial authorship and professional acting successfully by the mid 1780s. In addition to acting she also appeared on stage as a declamation artist, and was a sought after public speaker. The novelty effect for contemporaries must have been enormous since she, as a woman, combined her professional accomplishments as a writer, declamation artist, speaker, and actress, clearly rooted in the public sphere of the German cultural scene. Needless to say, her daring enterprises were an enormous violation against the female gender role.

Some of her biographers mentioned in connection with her daring career move as an actress, the necessary approval from her husband and her reputable family. They also pointed out Johann's likely negotiations for conditions in her contracts with respective theatre directors. ${ }^{85}$ Theatre directors preferred the commitment of married actresses in order to avoid the immoral projections of

\footnotetext{
82 Estimate at: Royer, Sophie, 44.

83 This was her last independent publication, since the established book trade had destroyed most self-publishers by the mid-eighties and drove a good number of daring publishing projects, such as the aforementioned "Buchhandlung der Gelehrten" - but also "Albrecht und Compagnie" (1786) - into ruin.

84 For a comprehensive overview of review articles for this edition with excerpts, see: Royer, "Sophie Albrecht, ein künstlerisches Phänomen", 332-38.

85 Geisler, "Bruchstücke", 29. Compare also: Royer, Sophie, 6o.
} 
the audience from the outset. However, mutual professional interest in the theatre stage was predominant in both of the Albrechts: Johann's interest was apparent ever since his first drama publications of the mid-1770s. Though he did not pursue a career as an actor, he instead pursued that of a playwright. From the late 178 os, he staged some of his dramas ${ }^{86}$ at the Kurfürstlich Sächsisches Hoftheater (Electoral Saxon Court Theatre) where his wife was the celebrated star, seasonally performing in Dresden, Leipzig and Prague. Sophie Albrecht was engaged there as leading actress for over 10 years, between 2 May 1785 and 28 September 1795 . Although Johann was only moderately successful as a playwright, his merit as an author lay more in key political novels.

First in autumn of 1783 , Sophie Albrecht had officially started her career as an actress in Gustav Friedrich Wilhelm Großmann's theatre company. One of her signature roles was "Louise" in Friedrich Schiller's drama Love and Intrigue. For the premiere on the 13 April 1784 in Frankfurt am Main, she met Schiller and they made friends instantly. About a year later, she accelerated her acting career by signing up with the aforementioned Pasquale Bondini's Kurfürstlich Sächsisches Hoftheater (Electoral Saxon Court Theatre) in Leipzig. She immediately became the crowd favourite and the guarantor for large audiences, as is evident from the various playbills of the time..$^{87}$ It was posted in the Ephemeriden der Litteratur und des Theaters how much she was welcomed into her engagement in Leipzig. 88 The Magazin der sächsischen Geschichte promptly made the next move in welcoming her. ${ }^{89}$ Albrecht used her popularity and stage presence to hold specially composed speeches for the stage and to have them printed, such as the "Abschiedsrede von Leipzig" (Farewell Speech from

86 Compare his drama collection: J.F.E. Albrecht. Dramatische Werke für das Hoftheater in Dresden gearbeitet. Prag 179o. Therein: Zieh aus Herr Bruder!, Fürstenglück und Die Engländer in Amerika. The drama Zieh aus Herr Bruder! was performed for example on 11 October 1789 in Leipzig. His wife was the leading female actress. Compare: Playbill advertising at Stadtgeschichtliches Museum Leipzig, i.e. Inventory No. MT/693//2006.

87 The Stadtgeschichtliches Museum Leipzig owns many playbills. The audience was attracted by Albrecht's specially indented and printed name with big letters to see her in various roles: On 16 April 1785 in the tragedy Graf von Esser, Inventory-No.: MT/658/2006; and in the female leading role of "Ophelia" in Shakespeare's Hamlet on 19 April 1785, No. MT/659/2006, also on 8 October 1791, No. MT/743/2006; "Desdemona” in Shakespeare's Othello for example on 19 June 1795, No. MT/952/2006; last in this role there on 28 September 1795, No. MT/993/2006.

88 Ephemeriden der Litteratur und des Theaters, ed. C.A. Bertram, Berlin 1785, 143, 288, and 394 .

89 Magazin der sächsischen Geschichte II, Dresden 1785. Segment: "Vermischten Dresdner Nachrichten", 707 . 
Leipzig) on 16 October $1785,{ }^{90}$ the "Abschiedsrede von Prag" (Farewell Speech from Prague) on 3 September, $1786,{ }^{91}$ or the "Rede bei Eröffnung der Bühne in Leipzig" (Speech at the Opening of the Stage in Leipzig) on 10 April $1787 ;{ }^{92}$ to mention a few.

She was praised in rapturous poems by contemporaries and admired, both as a poet and an actress. The critic and poet F.V. Freitag summed it all up in a poem about Sophie Albrecht and insisted that the two gods for literature and drama provided the laurel in her honour. ${ }^{93}$ On a single page, the Magazin der sächsischen Geschichte claimed: "Madam Albrecht is the goddess of our stage" and a few lines below: "That she is the first of all now living poets, I dare to bestow boldly."94 The euphoria that her stardom triggered both as poet and actress for contemporaries was unparalleled, and created a kind of media presence that was unknown before. It can be described as a multi-media artistic presence of her person in the press as well as with the theatre audience. Her star was rising in every aspect, but also economically: Sophie Albrecht's financial independence was partly attributable to her book sales, a considerable inheritance, and her unusually high salaries as an actress. ${ }^{95}$ Her financial success meant a personal freedom that was out of the ordinary experience of

90 "Farewell Speech from Leipzig" on 16 October 1785: "Abschiedsrede im Charakter der Louise in Verbrechen aus Ehrsucht von Sophie Albrecht. Leipzig, 16.10.1785", in Dreßdner Museum: Zwey-monatsschrift, ed. H. Keller, Heft 2, Dresden 1786, 9-10.

"Farewell Speech from Prague" on 3 September 1786: "Abschiedsrede beym Schluß der Vorstellungen der Bondinischen Gesellschaft in Prag. Von Sophie Albrecht am 3. Sept. 1786", in Theaterkalender auf das Jahr 1787, ed. H.A.O. Reichard, Gotha 1787, 245-47. "Speech at the Opening of the Stage in Leipzig" on 10 April 1787; Reinecke, Biographien, 18-20.

93 This example by F.V. Freytag in: Theater-Kalender auf das Jahr 1786, Gotha 1786, 12-13. Poem: "An Sophie Albrecht": "Tief eingeprägt, gesichert vor dem Sturm/ Der Zeit, war hier Dein Nahme edles Weib!/ Zwei Götter hielten Lorbeern über ihm/ Weil beider Götter Priesterin Du bist."

94 Compare: Magazin der sächsischen Geschichte, 1786, 528: "Madam Albrecht ist die Göttin unsrer Bühne", and: "Daß sie unter allen jetztlebenden Dichterinnen die erste sey, getraue ich mich keck zu erweisen."

95 About the inheritance, see: Geisler, Galerie edler teutscher Frauenzimmer, Band 2, Heft 3, 1785, Anhang: "Nachholungen zu Madame Albrecht", 194-97: "[die Erbschaft betrug] wenigstens 12 bis 16 ooo Thaler". Regarding her salary as an actress, see: Annalen des Theaters, ed. C.A. Bertram, Berlin 1788, 123: it amounted then to 1000 thaler, annually. She was the highest paid actress at the Electoral Saxon Court Theatre, earning as much as, for example, Adelung as Councilor in his position as Chief Librarian. See: Magazin der sächsischen Geschichte, 1787, 443. In 1795, she was paid a salary of 1400 thalers; she was the actress with the highest income and only her male counterparts earned more. See: HansWerner Engels, "Johann Friedrich Ernst Albrecht (1752-1814) und das National-Theater in Altona", Zeitschrift des Vereins für Hamburgische Geschichte, 86 (200oa), 14. 
most middle-class women in the period. She invested her money in various ways, and made her own financial decisions. ${ }^{96}$ At the same time, during the mid 178os, her marriage to Johann failed, and he remained a financial burden on her for the rest of her life. Although the couple did not divorce during that time frame, both engaged publicly in extra-marital affairs.

Sophie Albrecht was a sought after poet who had published her poetry at least once per year in many select magazines between 1780 to 1807 , including Christoph Martin Wieland's Der teutsche Merkur, ${ }^{97}$ in Sophie La Roche's famous women's magazine Pomona, ${ }^{98}$ in Gottfried August Bürger's Musenalmanach, ${ }^{99}$ in Friedrich Schiller's Thalia, ${ }^{100}$ in the remarkable women's publishing project Museum für Frauenzimmer, ${ }^{101}$ in Taschenbuch zum geselligen Vergnügen, ${ }^{102}$ and in Johann Heinrich Voß' Musenalmanach. ${ }^{103}$ From one of the few surviving letters of Albrecht to the editor Heinrich Voß, dated 14 March 1792, ${ }^{104}$ it appears that he had specifically asked for a contribution to his almanac. Unfortunately though, information regarding honoraria from poem contributions in this period is limited. It was customary to supply an author with a few copies of the periodical, or other print media, instead of monetary honoraria.

96 In the letter of her lover, Ferdinand von Hahn (1768-1799/1802?), to his mother from 25 May 1788, he stated that she wanted to settle his debts with the selling of bonds. This suggests that she had invested her money in different ways. See letter in: Hans-Werner Engels, "Die bizarre Ehe von Sophie und Johann Friedrich Ernst Albrecht - Dokumente zu zwei Prominenten der Goethezeit", in Auskunft, Bd.21, Heft 1, Nordhausen 2001, 16.

"Die ersten Blümchen, die ich fand" (music by Corona Schröter), in Der teutsche Merkur, ed. Wieland, 2. Vierteljahr, Weimar 1780, 200.

98 Sophie von La Roche ed., Pomona für Teutschlands Töchter, Heft 3, Speier 1783. Therein: "Lied" with music, 250; Heft 10, therein: "Der Wächter", 969-970; "An das Meer", 971-972.

99 Musenalmanach, ed. G.A. Bürger, Göttingen 1785. Therein: “Lied”, 166, “Entschluß”, 176.

100 Thalia, ed. Friedrich Schiller, 1. Bd., Heft 2, Leipzig 1786. Therein: "Morgenlied”, 69-70.

101 Museum für Frauenzimmer von einigen Mitschwestern, 4 quarters, Erstes Quartal, Weißenfels und Leipzig 179o: dedicated to Sophie von La Roche and with a poem in honour of "An Sophie Albrecht", and by herself: "Das Veilchen". Zweites Quartal dedicated to Elise von der Recke. In Viertes Quartal "Der Frau Kriegsräthin Reinhold am 17. März 179o" by Sophie Albrecht.

102 Taschenbuch zum geselligen Vergnügen, ed. Johann E.F.W. Müller, Leipzig 1791. Therein: "Wenn einstens", 6o, "Lieblich ist [...]", 6o, "Die grausamste Tyrannin [...]", 63, "Zypressen [...]", 63, "Mit doppelter Wonne [...]", 63 .

103 Musenalmanach, ed. J.H. Voß, Hamburg 1793. Therein: "Frühlingslied", 106.

104 A letter from S. Albrecht to Johann Heinrich Voß from 14.3.1792, Call no.: ASL 18 / Mediennummer: HSo17035923, University Library Leipzig. The obtained letter corpus of Sophie Albrecht and her contacts as a whole is unfortunately particularly small. See: Royer, Sophie, letter appendix / Briefanhang, $364-75$. 
The independent success of Albrecht, who did not have to be the muse of a famous man was a rare phenomenon in Germany. Her social contact with many writers, numerous celebrities, and royalty was significant. She performed in Prague before the last Emperor of the Holy Roman Empire of the German Nation, Francis II, and his entire court under "expressions of the loudest applause" on 31 July $1792 .{ }^{105}$ The stories about her renowned acquaintances are endless.

Moreover, she was the only German woman writer in the late eighteenth century, who had witnessed the publication of a complete edition of her poetry, drama and prose during her lifetime. Her third volume of poems with continued prose essays, "Fortgesetzte Fragmente aus dem Tagebuch einer Unglücklichen" (Continued Fragments from the Diary of an Unfortunate Woman), appeared in 1791. This third volume being part of the complete edition, along with the second edition of her two first volumes, was published at Richter in Dresden. Albrecht's complete three-volume edition was sold for two thalers, 12 groschen, which must have resulted in a good profit for the publisher. With an estimated circulation of 700, ${ }^{106}$ one could expect takings around 1,000 imperial thaler altogether. However, it is hard to say which part of the profit Sophie Albrecht did receive herself for this complete edition. At the height of her literary success, financial independence through inheritance along with her high salary as an actress, honoraria or royalties from book sales may not have been so important. As it may be, the prestige of publishing with the noted publishing house Richter in Dresden was sufficient honour for her during this period in her life.

Contemporary reviewers met Sophie Albrecht's third volume of poetry with prose essays again in an ambiguous fashion. ${ }^{107}$ There were ample supporters from her network, as well as critics from old-established periodicals. Nonetheless, she simply continued with her artistic production of literary texts and gathered an enthusiastic, benevolent and loyal audience around her.

In 1792, her estranged husband, Johann, resumed his publishing business in Prague (until 1795). The couple still continued with a business relationship, mutually engaged in some joint ventures, and it was said that Sophie supported

105 Compare: Annalen des Theaters, ed. Bertram, Berlin 1792/93, 104-5: "[Unter] Ausdrücken der lautesten Zufriedenheit Dero Beyfall über die Vortrefflichkeit des Stücks und das gute Ensemble der Schauspieler." Further visits of performances by the Emperor on 9 August, 13 August, and in the evening before his departure, on 15 August 1792.

106 Estimate see: Royer, Sophie, 44-45.

107 For an overview with excerpts from review periodicals see: Royer, "Sophie Albrecht, ein künstlerisches Phänomen", 399-442. 
Johann's publishing business. He published a collection of songs based on Sophie Albrecht's selected poems set to music by Franz Strohbach: among them was her translated "Song of Desdemona" from Shakespeare's Othello. Further publications of hers in that time frame appeared in the journal Apollo: "Die vergebliche Mühe" (The Futile Effort), set to music by Friedrich Heinrich Himmel. ${ }^{108}$ In Johann's monthly periodical Exkorporationen, she also published some of her poems and prayers. ${ }^{109}$ It is not quite clear, if Albrecht had any part in the editing or publishing activity of "Albrecht und Compagnie" herself during that time frame. A contemporary ${ }^{110}$ thought so, however, and attributed the edition of Wilhelmine von Gersdorf's three-volume novel Die Familie Wahlberg in 1792 to her. If it was Sophie Albrecht, who promoted her close friend's writing, she might have also been responsible for the publication of Gersdorf's drama collection Dialogen in 1794; the year thereafter published Neue Schauspiele (New Dramas). ${ }^{111}$

During the same year, Sophie Albrecht published some of her poems with the radical intellectual Gottfried Vollmer in Neue Blumenlese. ${ }^{12}$ By the early 179os, her political involvement with the democratic movement, the Freemasons, and with French revolutionary followers intensified.

\section{Publications in Northern Germany, the Altona National Theatre, and Indissoluble Financial Entanglements}

Biographers described Sophie Albrecht's increasing dissatisfaction as an actress working under the direction of her colleague and adversary, Christian Wilhelm Opitz, at the Kurfürstlich Sächsisches Hoftheater (Electoral Saxon Court Theatre). Incidentally, Opitz was an enemy of the democratic

108 Franz Strohbach, Zwölf Lieder von Sophie Albrecht für das Fortepiano gesetzt von Franz Strohbach, Teil 2, Prag 1792. Therein: "Lied der Desdemona: Ein armes Mädchen saß und sang". Translated by S. Albrecht. And: Friedrich Heinrich Himmel, "Die vergebliche Mühe": Lied v. S. Albrecht, Apollo, Monatsschrift, ed. A.G. Meißner, 4/6 (1793); 4/2 (1793), therein: "Ein Felsengrund schien seine Liebe, und Ewigkeit war sein Eid"; Lied.

109 Exkorporationen, Monatsschrift, ed. J.F.E. Albrecht, Dresden u. Leipzig 1791. Therein: "An J.K.R. an seinem Geburtsstage", 681-83, "An Minna", 689-93, "An Sophie" 694-98 (lyrical answer by her friend Wilhelmine von Gersdorf). In September 1791: "Gebete" (7), 854-66.

110 Literarische Beyträge zu einer nützlichen Bücherkunde für gebildete Frauenzimmer, J.G.C. Müller, Nürnberg 1823, 118.

111 Wilhelmine von Gersdorf, Die Familie Wahlberg, 1792; Dialogen, 1794; Neue Schauspiele, 1795, all published at Prag und Leipzig.

112 Neue Blumenlese deutscher Originalgedichte und Uebersezungen für das Jahr 1794, Thorn 1794 . 
movement to which Albrecht belonged. As a result, she bowed out from her enormously successful and lucrative engagement at the court theatre in Leipzig. Her last recorded performance was on 28 September 1795 in the role of "Desdemona" in Shakespeare's Othello. ${ }^{113}$ She left Saxony during the autumn in 1795 to play guest roles in Hamburg, though no theatre engagement was offered to her there. As a consequence, she opened the Altona National Theatre ${ }^{114}$ together with her estranged husband Johann in the immediate Danish neighbouring town of Altona on 1 September 1796. On stage she gave speeches ${ }^{115}$ for special occasions, played the female lead roles, ${ }^{116}$ moved on with her activities as a writer, and continued to carry on her public life amidst the society of Hamburg and Altona. The Freemasons held her in high regard and in 1796, she was elected Grand Mistress of the Sisters "Carl zum Felsen" lodge in Altona. ${ }^{117}$ Additionally, more of her religious prose appeared during this period, such as "Frömmigkeit wird belohnt" (Piety is Rewarded) $)^{118}$ and "Die reiche Anna" (The Rich Anna) ${ }^{119}$ in the collection of Johann Albrecht's Trümmer der Vergangenheit (Remnants of the Past). Furthermore, she published some poems in his politically-oriented magazine Todtenrichter, ${ }^{120}$ and even more poems and orated speeches appeared in several other magazines.

113 Compare: Stadtgeschichtliches Museum Leipzig, Playbill Inventory No. MT/993/20o6.

114 A number of contributions have already been written about the Altona National Theatre and its importance for the democratic movement in Germany, including: Engels, "National-Theater in Altona"; Royer, Sophie, 77-103; Walter Grab, Demokratische Strömungen in Hamburg und Schleswig-Holstein zur Zeit der ersten französischen Republik, Hamburg 1966, 177-84; Paul Th. Hoffmann, Die Entwicklung des Altonaer Stadttheaters, Altona 1926.

115 For example: "Antritts-Rede bey Eröffnung des National-Theaters in Altona am 1sten September 1796 von Sophie Albrecht", in (among others) Journal der neuesten Weltbegebenheiten 9 (1796), 574-76.

116 Poster reads: "Am 1. September 1796, wird im neu eröffneten Altonaer National-Theater mit Julius von Sassen, [Trauerspiel, 4 Aufzüge, von Heinrich Zschokke, womöglich die Uraufführung, B.R.] eröffnet. Personen: [...], Henriette, - wurde von Sophie Albrecht gespielt." Staatsarchiv Hamburg. The extent of her acting repertoire would go way beyond the scope of this contribution.

117 See: Hans-Werner Engels, 'Carl zum Felsen': Vorgeschichte und Gründung der Altonaer Loge, Hamburg 2ooob.

118 In Trümmer der Vergangenheit. Aus ihren Ruinen ans Licht gebracht, 2. Teil, Hamburg 1797.

119 In Trümmer der Vergangenheit. Erzählungen aus dem Dunkel der Vorzeit, 3. Teil, Hamburg 1801.

120 Todtenrichter, Ein periodisches Werk, Vom Verfasser der dreyerley Wirkungen [J.F.E. Albrecht], 2. Bde., Altona 1796 \& 1797. Therein: 1. Bd., 1796: Gedicht "Am Grabe einer Freundin", 95-96, und "Fantasie", 255-56. 
A divorce from Johann was supposed to have taken place during the year 1798, and speculations about a marriage with her long-time lover, Ferdinand von Hahn, were mentioned, but this cannot be verified. ${ }^{121}$

From 1797, she turned to the genre of Gothic novels and published them in Altona with Friedrich Bechtold, owner of the most important Jacobin's publishing company in Germany. The first of the two novels was Das höfliche Gespenst / Ida von Duba (The Polite Ghost / Ida of Duba). ${ }^{122}$ This extraordinary novel provides an entirely woman-centred narration about the period of mourning of a protagonist living in seclusion. There, a female ghost attempts to selfishly seduce the protagonist to receive redemption for her misdeeds against her mother. This is one of the earliest examples of a female homoerotic epic in Germany. ${ }^{123}$ The critic for the Allgemeiner Litterarischer Anzeiger, ${ }^{124}$ however, simply mentioned Albrecht's new publication without describing the content at all. Two months later, the supplement of the same periodical ${ }^{125}$ published the retail price for the book Das höfliche Gespenst / Ida von Duba at 16 groschen (by 1805 the price for the novel had increased to 20 groschen). Albrecht was greatly praised there for her full achievements as a writer, and additionally for her new novel. Referring to Albrecht as "Madame S. A." already well known to the literary audience as one of the prime women writers in Germany, the reviewer rated the novel a "pleasant gift, especially to the fair sex, [and] a very entertaining reading." Like many reviewers before and after him, he made sure to hint that the target audience was exclusively female. ${ }^{126}$

As early as 1799, reference was made to the next Gothic novel by Albrecht Graumännchen oder die Burg Rabenbühl (Graumännchen or the Castle Rabenbühl) in Allgemeine Literatur-Zeitung. ${ }^{127}$ The "Intelligenzblatt" of $A L Z^{128}$ then used a multiple-page announcement and included rating of the new Gothic

121 Royer, Sophie, 91. There is no documentary evidence of a divorce from Johann, and the same applies to the alleged marriage to her lover Ferdinand von Hahn. See: Royer, "Sophie Albrecht, ein künstlerisches Phänomen", 348.

122 Published under altogether three titles: Legenden / Das höfliche Gespenst. Legende (1797) and Ida von Duba das Mädchen im Walde (1805).

123 See analysis in: Royer, Sophie, 242-56.

124 Allgemeiner Litterarischer Anzeiger, 12. April 1798, Leipzig 1798, 602-3.

125 Allgemeiner Litterarischer Anzeiger, Beilage zu No. CII, 29. Juni 1798, Leipzig 1798, $1037-38$.

126 Unfortunately, the extent of reception from review periodicals between 1795 and 1808 goes beyond the scope of this contribution.

127 Allgemeine Literatur-Zeitung vom Jahre 1799, Jena und Leipzig 1799, iii.

128 Intelligenzblatt der $A L Z$ vom Jahre 1799: 323, 407-8, 629 (and with mentioning the price), 1077 . 
novel, provided by the publishing company. ${ }^{129}$ The advertisement was overall about Albrecht's popularity and the quality of her writing, the price of this novel at 16 groschen, and its availability from the upcoming Leipzig book fair. ${ }^{130}$ The novel Graumännchen oder die Burg Rabenbühl, which was published as a "ghost story", portrays a young woman developing emotional maturity against the backdrop of her family history. By using motifs from fairy tales, which originated from the rich tradition of the French fairy tales by Marie C. d'Aulnoy, Marie J. L'Héritier de Villandon and Charles Perrault, Albrecht contributed with her work also crucially to the Brothers Grimm's later version "Rumpelstiltskin" (Rumpelstilzchen, 1812). This novel was so popular that it was translated into Dutch in the year $1801{ }^{131}$ The outstanding attribute of Albrecht's writing practice was the inclusion of the tradition of Women's Writing, which contributed to the continuing recovery of its literary historical memory.

During the same period, the composer K.W. Ulbricht set to music Albrecht's poem "Der Kummer verschmähter Liebe" (The Grief of Rejected Love) ${ }^{132}$ as declamatory piece with musical accompaniment for the piano; this edition was sold in 1801 for 10 groschen. In 1804, Albrecht's complete three-volume edition of poetry, drama and short prose from 1791 was sold off at Richter's for the first time. Thirteen years after first publication, a special discount was given: the price was reduced from two thaler, 12 groschen to one thaler, 12 groschen. The complete edition must have sold well until then. ${ }^{133}$

Four years later, in 1808, Albrecht's Romantische Dichtungen (Romantic Poetry ${ }^{134}$ appeared with the radical intellectual Gottfried Vollmer once more as

129 This is the "Buchhandlung der Verlagsgesellschaft", which was managed by Evers and Schmieder in the absence of Vollmer; all representatives of the radical democracy movement and Masonic brothers. During the same period, Albrecht's friends Félicité de Genlis, Elise Bürger, and Henriette von Montenglaut published at Vollmer's.

130 Compare: Intelligenzblatt der ALZ vom Jahre 1799: "Von der beliebten Schriftstellerin Sophie Albrecht erscheint in bevorstehender Leipziger Oster-Messe ein neuer Roman [...]. Derselbe Beyfall, welcher ihren frühern Arbeiten zu Theil ward, wird auch dieser neuen für die Unterhaltung bestimmten Schrift nicht entgehen. Wir glauben den Dank der Lesewelt zu verdienen, wenn wir die Anzeige davon vorläufig erscheinen lassen, und zugleich dadurch die Erwartung und Aufmerksamkeit zum voraus darauf lenken."

131 Compare: Sophie Albrecht, Het grauwe mannetjen of De burgt Ravenkuil, Eene Geesten Geschiedenis van Oud Duitschen Oirsprong, [Translator unknown], Amsterdam 1801.

132 K.W. Ulbricht, "Der Kummer verschmähter Liebe" von Sophie Albrecht; als Deklamationsstück mit musikalischer Begleitung [...], Dresden 1801. Announced in Intelligenzblatt zu Allgemeine Musikalische Zeitung Ix (June 1801), 36.

133 Zeitung für die elegante Welt. Intelligenzblatt [...], 39 (6 September 1804), 14.

134 Romantische Dichtungen, aus der älteren christlichen Kirche, Sophie Albrecht, Hamburg und Altona 1808. 
publisher, and was sold for 12 groschen. It is difficult to determine how large the circulation, sold copies, and respective profits for these publications ultimately were for the author. It is striking, however, that her publications almost completely ceased at this time around 1808 . That might have been due to personal, as well as political and economic reasons. The occupation of northern Germany by Napoleon's troops, the Continental Blockade and its devastating economic effects might have all contributed to her silence as a writer. At the same time, her withdrawal from the literary public might have had also something to do with the anti-egalitarian backlash that accompanied the late Napoleonic age, which changed the role of women drastically again. After a brief period of emancipation, women were again strictly relegated to domesticity. Women and the public sphere had become once again incompatible. ${ }^{135}$

\section{A Room of One's Own, but No Money to Maintain It: Final Thoughts}

Sophie Albrecht was one of the most unusual artistic personalities of the German-speaking cultural areas: she had been able - as writer, editor, publisher, declamatory artist, and public speaker - to mobilise coordinated networks in the public sphere. She knew how to deal effectively with publishers and achieved handsome profits through her publications. Particularly noteworthy are her networks among like-minded women, and her fabulous dual professional career in the performing arts. What could only be hinted at was her involvement in the democracy movement, apparent through writings, contacts with politically, equally-disposed people, her memberships in Masonic lodges and her active support of revolution followers. ${ }^{136}$ She was ahead of her time, and received well by her immediate like-minded and copious circle of active supporters. However, conservative critics of established review organs mainly rated Albrecht's literary works as permissible or impermissible acts within social, and cultural gender role patterns. On the whole, it seems that reviewers can be categorised either as proponents or opponents of female artistic (and "learned") activity in the late eighteenth century. They mentioned neither Albrecht's critical perspective on marriage, love, sexuality with men and women, friendship, nor her lack of specification in the class portrayals of her

\footnotetext{
135 Brandes, "Buch", 310, mentioned this process in relation to the German writer Sophie von La Roche for this approximate time frame.

136 René-Marc Pille, "Eine Gruppe Sympathisanten der Französischen Revolution in Leipzig", in Die Französische Revolution, Mitteleuropa und Italien, ed. Helmut Reinalter, Frankfurt 1992, 141-50.
} 
protagonists. In brief, her essentially anachronistic effort to aim for modern democratic citizenship concepts for women collided with the immense discriminatory structure against them in society.

Sophie Albrecht's star began to decline as her political camp in the democracy movement in Germany lost influence and as the hope for women's equality in the aftermath of the French Revolution gradually lost its credibility. The late Napoleonic age, the occupation of Germany, and the wars that finally marked the end of that period, described the starting point of a new era of suppression. The Conservative Restoration put political opponents in their place after 1815 with repressive decrees, censorship measures, and the suppression of liberal newspapers. As a well-known participant of the democratic opposition, Sophie Albrecht could not recover her public esteem during the oppressive circumstances of the post Viennese-Congress era.

It was just as difficult for her circle of like-minded friends, other women writers. They were also struggling to support themselves financially with commercial authorship. In 1819, Albrecht's colleague and friend, Henriette von Montenglaut, asked the once successful writer for guidance:

Well, dear Sophie give me good advice, or even better bring yourself into action for me with distant theatres - just not in Leipzig, because of the fairs - because I'm just too much known among the circles with my real name. Also, I have published a small volume of poems, that Matthison has kindly reviewed - Herbstblumen Kranz ${ }^{137}$ Some I wrote for the Morgenblatt, and, after I had finished 2 dozen shirts for my sons with blind eyes through spectacles, I am now working on a small volume of stories that I want to publish at Göschen's for the hungry in the Ore Mountains. Everything was formerly self-published and therefore with little profit. - Just tell me how to deal with publishers, and how to make money with writing?138

Montenglaut could no longer obtain a satisfactory answer from her friend: $\mathrm{Al}$ brecht herself could barely make do with odd jobs, a few thaler from royalties and those for her late husband Johann, who had passed away on 11 March 1814. With the loss of all her property and possessions, ${ }^{139}$ between 1806 and 1814, the

\section{Herbstblumenkranz, Darmstadt 1814.}

138 Royer, Sophie, letter appendix / Briefanhang, letter by Montenglaut from 3 July 1819, 370-74.

139 Albrecht once owned the "Rose Garden", prime real estate along the Elbchaussee, Altona. She purchased this property in 1799 , built a country house on the site, and lived there until 1806. For a description of all the valuable real estate she owned in Altona, see: Paul Hoffmann, Die Elbchaussee, Ihre Landsitze, Menschen und Schicksale, Hamburg $1966,82-83$. She had additionally purchased real estate at the Altona showpiece street 
ruinous financial support for her estranged husband, and the pecuniary assistance to the Altona National Theatre, she never recovered and experienced continuing financial hardship for the remainder of her life. Although the city of Hamburg bestowed a small cottage on her in the 1820s at the "Hamburger Berg" for ten thaler annually, ${ }^{140}$ she still remained in desperate need. She was active in literature again for a very short period, whenever the fight for the "room of one's own" did not rob her of her creative inspiration. It was only when her friend Montenglaut secured a small pension by the "anonymous" Germany-wide appeal, that she wrote some poems for Dresdner-Abend-Zeitung in 1828 and 1832 . More than that and a poem in a letter, probably from 1838 , have not been preserved from this late stage of her life. She died on 16 November 1840 in Hamburg and was buried there in the cemetery in St. Georg.

\section{Bibliography}

\section{Primary References}

\section{[Works by Sophie Albrecht]}

Lauschen ist auch gut, ein Singspiel in zwey Aufzügen von einem Frauenzimmer. 1780. Reval und Leipzig: Albrecht und Compagnie.

Gedichte und Schauspiele. (Contains her two dramas: Lauschen ist auch gut and Theresgen). 1781. Vol I. Erfurt: In Commißion bey Albrecht und Compagnie.

Gedichte und Prosaische Aufsätze. (Contains Prose: "Fragmente aus dem Tagebuch einer Unglücklichen"). 1785. Vol II. Erfurt: In Kommißion bey Albrecht und Compagnie. Aramena, eine syrische Geschichte, ganz für unsere Zeiten von S. Albrecht umgearbeitet. 1782-86. 3 vols. Berlin: Decker.

Gedichte und Prosaische Aufsätze (Vol III contains: "Fortgesetzte Fragmente aus dem Tagebuch einer Unglücklichen"). 1791. Vols I (second edition of "Gedichte und Schauspiele", 1781) and II (second edition of "Gedichte und Prosaische Aufsätze", 1785). Three volume edition. Dresden: Richter.

Legenden von S.A. 1797. Altona und Leipzig: Friedrich Bechtold. 1797. (Published with three titles: Das höfliche Gespenst. Legende von S.A. (1797), Legende von S.A. (1797), Ida von Duba das Mädchen im Walde. Eine romantische Geschichte aus den grauenvollen Tagen der Vorwelt. 1805. Altona: Bechtold.)

Palmaille in 180o, and on two other local roads; they were worth 27,800 marks courant. Compare: Royer, Sophie, 91.

140 Montenglaut, "Biographische Skizze", 974, and her letter to Goethe from 1828. 
"Frömmigkeit wird belohnt", in Trümmer der Vergangenheit. Aus ihren Ruinen ans Licht gebracht. (Published together with J.F.E. Albrecht's stories). 1797. Vol II. Hamburg: Hoffmann.

Graumännchen oder die Burg Rabenbühl. Eine Geistergeschichte altdeutschen Ursprungs von S.A. 1799. Hamburg und Altona: Buchhandlung der Verlagsgesellschaft.

"Die reiche Anna oder Unserer lieben Frauen Bild in Litthauen, Erzählung aus dem 12ten Jahrhundert", in Trümmer der Vergangenheit. Erzählungen aus dem Dunkel der Vorzeit. (Published together with J.F.E. Albrecht's stories) 1801. Vol III. Hamburg: Hoffmann.

Romantische Dichtungen, aus der älteren christlichen Kirche. Sophie Albrecht. 1808. Hamburg und Altona: Vollmer.

\section{[Poetry, Speeches, and Poems by Sophie Albrecht in Musical Settings, Published in Almanacs, Periodicals, Song-Collections (Excerpts Only)]}

Ehstländische poetische Blumenlese für das Jahr 1779. Albrecht, J.F.E. und Sophie ("Die Herausgeber"). 1779. Wesenberg: Albrecht und Compagnie.

Estländische poetische Blumenlese für das Jahr 1780. Albrecht, J.F.E. und Sophie. 1780. Leipzig u. Reval: Albrecht und Compagnie.

"Die ersten Blümchen die ich fand", set to music by Corona Schröter, in C.M. Wieland (ed.), Der teutsche Merkur 2. 1780. Weimar.

Lieder mit Clavierbegleitung, für Liebhaber eines leichten und fließenden Gesanges. Therein: Six Sophie Albrecht poems set to music by Georg Peter Weimar. 1780. Reval u. Leipzig: Albrecht und Compagnie.

Sophie von La Roche (ed.), Pomona für Teutschlands Töchter, Therein: "Lied" (and sheet music, possibly by Joseph Aloys Schmidtbauer) in Vol 3, "Der Wächter"; "An das Meer" in Vol 10. 1783. Speier: Enders.

"Lied" and "Entschluß", in Gottfried A. Bürger (ed.), Musenalmanach. 1785. Göttingen: Dieterich.

"Abschiedsrede im Charakter der Louise in Verbrechen aus Ehrsucht", von Sophie Albrecht [Farewell Speech from Leipzig]. Leipzig, den 16.10.1785.", in Heinrich Keller (ed.), Dreßdner Museum: eine Zwey-monatsschrift 2 (1785). 1786. Dresden: Gerlach.

"Morgenlied", in Friedrich Schiller (ed.), Thalia 1 (2). 1786. Leipzig: Göschen.

"Abschiedsrede beym Schluß der Vorstellungen der Bondinischen Gesellschaft in Prag. Verfertigt und gesprochen von Sophie Albrecht am 3. Sept. 1786", in H.A.O. Reichard (ed.), Theaterkalender auf das Jahr 1787. 1787. Gotha: Ettinger.

"Rede bei Eröffnung der Bühne in Leipzig, den 1oten April 1787", in Johann Friedrich Reinecke (ed.), Biographien einiger deutschen Schauspielerinnen. Vol I. 1787. Kopenhagen u. Leipzig: Krögen. 
"Das Veilchen" in: Museum für Frauenzimmer von einigen Mitschwestern. Vol I. 179o. Leipzig: Severin. (Altogether 4 volumes were published; Vol I Designated to Sophie von La Roche, therein a poem to S.A. "An Sophie Albrecht"; Vol II, Designated to Elise von der Recke.)

"Der Frau Kriegsräthin Reinhold am 17. März 179o", in Museum für Frauenzimmer von einigen Mitschwestern. Vol IV. 179o. Leipzig: Severin.

"An J.K.R. an seinem Geburtsstage", "An Minna", and "Gebete" (seven altogether), September 1791, in J.F.E. Albrecht (ed.), Exkorporationen, Monatsschrift. 1791. Dresden und Leipzig: Richter.

"Wenn einstens", "Lieblich ist", "Die grausamste Tyrannin”, "Zypressen”, "Mit doppelter Wonne", in Johann E.F.W. Müller (ed.), Taschenbuch zum geselligen Vergnügen. 1791. Leipzig: Breitkopf.

"Zwölf Lieder von Sophie Albrecht" für das Fortepiano gesetzt von Franz Strohbach. Vol 2. 1792. Prag: Albrecht und Compagnie.

"Frühlingslied", in Johann Heinrich Voß (ed.), Musenalmanach. 1793. Hamburg: C.E. Bohn.

"Die vergebliche Mühe", Lied von Sophie Albrecht vertont von Friedrich Heinrich Himmel, in A.G. Meißner (ed.), Apollo, Monatsschrift Iv(6). 1793. Prag: Albrecht und Compagnie.

"Ein Felsengrund schien seine Liebe, und Ewigkeit war sein Eid"; Lied, in.G. Meißner (ed.), Apollo, Monatsschrift IV(2). 1793. Prag: Albrecht und Compagnie.

Vollmer, Gottfried (ed.), Neue Blumenlese deutscher Originalgedichte und Uebersezungen, für das Jahr 1794. 1794. Thorn u. Danzig: Vollmer.

"Antritts-Rede bey Eröffnung des National-Theaters in Altona am 1sten September 1796 verfertigt und gesprochen von Sophie Albrecht", in Journal der neuesten Weltbegebenheiten. Vol 9. 1796. Altona: Raven.

"Am Grabe einer Freundin" and "Fantasie", in [J.F.E. Albrecht (ed.)], Todtenrichter. Ein periodisches Werk. Vom Verfasser der dreyerley Wirkungen. Vol 2. 1796 \& 1797. Altona: Bechtold.

"Der Kummer verschmähter Liebe", als Deklamationsstück mit musikalischer Begleitung des Klaviers oder Pianoforte bearbeitet von K.W. Ulbricht. Dresden. Announced in Intelligenzblatt zu Allgemeine Musikalische Zeitung IX. June 1801. Leipzig: Breitkopf u. Härtel.

Dresdner Abend-Zeitung. 1828 \& 1832. Dresden u. Leipzig: Arnold.

\section{[Translations by]}

Lied der Desdemona: "Ein armes Mädchen saß und sang". Übersetzt von Sophie Albrecht, vertont von Franz Strohbach. 1792. Prag: Albrecht und Compagnie. See:Jahrbuch der deutschen Shakespeare-Gesellschaft 37 (1901), 96.

Het grauwe mannetjen of De burgt Ravenkuil. Eene Geesten Geschiedenis van Oud Duitschen Oirsprong. [Translator unknown]. 1801. Amsterdam: Roos. 


\section{[Letters, in Chronological Order (Not Listed in Royer, Sophie, Letter Appendix/Briefanhang)]}

Ein Brief von Sophie Albrecht an Johann Heinrich Voß vom 14.3.1792. In Universitätsbibliothek Leipzig, Signatur: ASL 18 / Mediennummer: HSo17035923.

Ein Brief von Henriette von Montenglaut: Brief an Goethe vom 9.2.1828. GSA 28/128Weimar.

\section{[Other Unpublished Sources]}

Baptismal Register/ Kirchenbuch/Taufregister, $175^{6-58}$, der Sankt Bonifatiuskirche in Sömmerda, Thüringen, Germany.

Playbill Advertisement/Theaterzettel: Stadtgeschichtliches Museum Leipzig. Objektdatenbank. Musik- und Theatergeschichte, Theaterprogramme. Online at: http:// museum.zib.de/sgml_internet/sgml.php?seite $=\& d b=6$ (consulted 3.5.2014)

\section{Secondary References}

Adelung, J.C. (ed.), Allgemeines Verzeichniß Neuer Bücher, mit kurzen Anmerkungen. 1779/178o. Leipzig: Crusius.

Albrecht, Johann Friedrich Ernst. 179o. Dramatische Werke für das Hoftheater in Dresden gearbeitet. Prag: Calve.

Allgemeine Deutsche Bibliothek. 1779. Vol 37. Reviewer Pseudonym "Mpr". Berlin u. Stettin: Nicolai.

Allgemeine Deutsche Bibliothek. 1783 . Vol 55. Reviewer pseudonym "S". Berlin u. Stettin: Nicolai.

Allgemeine Deutsche Bibliothek. 1788. Vol 83. Reviewer pseudonym "Zf”. Berlin u. Stettin: Nicolai.

Allgemeine Literaturzeitung. 1788. Vol 1, 155. Jena \& Leipzig: Müller.

Allgemeine Literaturzeitung. 1799. Jena und Leipzig: Müller.

Allgemeine Literaturzeitung. 1799. Intelligenzblatt der ALZ. Jena \& Leipzig: Müller.

Allgemeiner Litterarischer Anzeiger, 12 April 1798. Leipzig: Expedition d. ALA.

Allgemeiner Litterarischer Anzeiger. 1798, appendix nr. CII, 29 June 1798 Leipzig: Expedition d. $A L A$.

Alt, Peter-André. 2009. Schiller, Vol. 1. München: Beck.

Annalen des Theaters. 1788. Ed. C.A. Bertram. Berlin: F. Maurer.

Annalen des Theaters. 1792/93. Ed. C.A. Bertram. Berlin: F. Maurer.

Berichte der allgemeinen Buchhandlung der Gelehrten. 1781. Dessau u. Leipzig: Buchhandlung der Gelehrten.

Brandes, Helga. 2004. 'Buch und Zeitschriftenmarkt, Frauenzimmer-Journale und Literaturkritik im 18. Jahrhundert' in Berbig, Roland, Lauster, Martina and Parr, Rolf (eds.) Zeitdiskurse, Reflexionen zum 19. und 20. Jahrhundert als Festschrift für Wulf Wülfing. Heidelberg: Synchron: 301-17. 
Brück, Helga. 1994. "Sophie Albrecht, Schauspielerin und Dichterin (1757-1840)" in Reihe 'Bemerkenswerte Erfurter' (VII), Thüringer Allgemeine Zeitung. Erfurt, Mai.

Der Patriot. 1724. Nr. 3 vom 20.1.1724. Hamburg: König.

Der teutsche Merkur. 1781. C. M. Wieland (ed.). 2. Vierteljahr. Weimar.

Die deutschen Schriftstellerinnen des 19. Jahrhunderts. 1823. Schindel, Carl Wilhelm August von (ed.). Bd. 1. Leipzig: Brockhaus.

Engels, Hans-Werner. 2000a. "Johann Friedrich Ernst Albrecht (1752-1814) und das National-Theater in Altona” in Zeitschrift des Vereins für Hamburgische Geschichte. Bd.86. Hamburg: Verlag Verein für Hamburgische Geschichte, 1-42.

Engels, Hans-Werner. 20oob. 'Carl zum Felsen': Vorgeschichte und Gründung der Altonaer Loge; Tätigkeit einiger Brüder bis zum Jahre 180o. Sonderdruck, erschienen in Hamburg. Engels, Hans-Werner. 2001. 'Die bizarre Ehe von Sophie und Johann Friedrich Ernst Albrecht Dokumente zu zwei Prominenten der Goethezei', in Auskunft, Zeitschrift für Bibliothek, Archiv und Information in Norddeutschland, Bd.21. Heft 1. Nordhausen: Bautz, 3-36.

Ephemeriden der Litteratur und des Theaters. 1785. Ed. C.A. Bertram. Berlin: Maurer. Erfurtisches Intelligenz-Blatt. 1782. Stück 46, Erfurt: Görling.

Evers, Barbara. 1991. Frauenlyrik um 180o. Studien zu Gedichtbeiträgen in Almanachen und Taschenbüchern der Romantik und Biedermeierzeit. Dissertation. Bochum: Universitätsverlag Brockmeyer.

Faulstich, Werner. 2002. Die bürgerliche Mediengesellschaft (1700-1830). Göttingen: Vandenhoeck \& Ruprecht.

Geisler, Adam (ed.). 1784. 'Bruchstücke aus dem Leben der deutschen Dichterin Sophie Albrecht' in Gallerie edler teutscher Frauenzimmer. Bd.1, Heft 1. Dessau u. Leipzig: Buchhandlung der Gelehrten, 139-168.

Geisler, Adam (ed.). 1785. 'Anhang. Nachholungen. Im 1sten Heft zu Madame Albrecht', in Gallerie edler teutscher Frauenzimmer, Bd.2. Heft 3. Dessau u. Leipzig: Buchhandlung der Gelehrten, 194-197.

Gersdorf, Wilhelmine von. 1792. Die Familie Wahlberg, Prag u. Leipzig: Albrecht und Compagnie.

Gersdorf, Wilhelmine von 1794. Dialogen, auch für die Bühne brauchbar. Prag u. Leipzig: Albrecht und Compagnie.

Gersdorf, Wilhelmine von 1795. Neue Schauspiele. Prag u. Leipzig: Albrecht und Compagnie.

Gothaische Gelehrte Zeitungen auf das Jahr 1781. Gotha: Ettinger.

Grab, Walter. 1966. Demokratische Strömungen in Hamburg und Schleswig-Holstein zur Zeit der ersten französischen Republik. Veröffentlichungen des Vereins für Hamburgische Geschichte Bd.xxI. Hamburg: Christians, 177-184.

Herder, Johann Gottfried. 1779. Volkslieder, nebst untermischten andern Stücken. Bd.2. Leipzig: Weygand. 
Hoffmann, Paul Th. 1926. Die Entwicklung des Altonaer Stadttheaters. Altona: Köbner.

Hoffmann, Paul Th. 1966. Die Elbchaussee, Ihre Landsitze, Menschen und Schicksale.

7. Hamburg: Broschek.

Jahrbuch der deutschen Shakespeare-Gesellschaft. 1901. Bd.37. Bochum: Kamp.

Journal von und für Deutschland. 1784. 1.Jg. Julius-December. Ellrich: Freyherr von Bibra u. Goekingk. And "Supplement Register".

Jestädt, Franz-Ulrich / Kaminski, Thomas. 2015. 'Druck- und Verlagsgeschichte als Rekonstruktion eines Lebensfragments' in Rüdiger Schütt (ed.) Verehrt. Verflucht. Vergessen. Leben und Werk von Sophie Albrecht und Johann Friedrich Ernst Albrecht. Hannover: Wehrhahn, 63-105.

Kahnt, Helmut und Bernd Knorr. 1986. Alte Maße, Münzen und Gewichte, ein Lexikon. Mannheim: BI-Wiss. Verlag.

Kamiensky, Friederike von. 1786. Meine Muse. Naumburg: Ulig.

Kiefer, J.D.K. 2005. Bio-bibliographisches Handbuch der Akademie Gemeinnütziger Wissenschaften zu Erfurt. 1754-2004. Erfurt: Akademie Gemeinn. Wiss. zu Erfurt.

Klein, Emil. 1905. 6 Bilder aus Schillers Leben. Stuttgart: Volkart.

La Roche, Sophie von (ed.). 1783-84. Pomona für Teutschlands Töchter. Speier: Endres.

Literarische Beyträge zu einer nützlichen Bücherkunde für gebildete Frauenzimmer. 1823. J.G.C. Müller, Nürnberg: Riegel u. Wiesner.

Lukas, Liina. 2011. 'Estonian Folklore as a Source of Baltic-German Poetry' in Journal of Baltic Studies 42:4, 491-510.

Magazin der sächsischen Geschichte. 1785. Hasche, Johann Christian (ed.). 2.Theil. Therein: "Vermischte Dresdner Nachrichten". Dresden: Hasche.

Magazin der sächsischen Geschichte. 1786. Hasche J. C. (ed.). 3.Theil. Therein: "Dresdner Merkwürdigkeiten". Dresden: Hasche.

Magazin der sächsischen Geschichte. 1787. Hasche J. C. (ed.). Dresden: Hasche.

Medicinische Biographie. 1829. Brüggemann, August (ed.). Halberstadt: Brüggemann.

Montenglaut, Henriette von. 1814. Herbstblumenkranz. Darmstadt: Stahl.

Montenglaut, Henriette von. 1828. 'Biographische Skizze der gewesenen Schauspielerin und noch immer still-wirkenden Dichterin Sophie Albrecht in Hamburg, nebst einer Aufforderung an die Deutsche Künstlerwelt' in Der Freimüthige. Berlin, Dezember 1828, 958-974.

Müller, Johann Sebastian. 170o. Des Chur- und Fürstlichen Hauses Sachsen, Ernestinund Albertinischer Linien Annales von 1400 - 170o. Leipzig: Gleditsch.

Niemeyer, Beatrix. 1996. 'Ausschluss oder Ausgrenzung? Frauen im Umkreis der Universitäten im 18. Jahrhundert' in Claudia Opitz and Elke Kleinau (eds). Geschichte der Mädchen- und Frauenbildung. Band 1. Frankfurt/New York: Campus, $275^{-294}$. 
Pille, René-Marc. 1992. 'Eine Gruppe Sympathisanten der Französischen Revolution in Leipzig' in Helmut Reinalter, in Die Französische Revolution, Mitteleuropa und Italien. Frankfurt a. M.: Lang. 141-150.

Reinecke, Johann Friedrich. 1787. Biographien einiger deutschen Schauspielerinnen, Gesammelt und herausgegeben von Reinecke. Bd.1. Kopenhagen u. Leipzig: Krögen, $1-20$.

Royer, Berit C.R. (ed.). 1997. "Begleittext" von der Herausgeberin. Bunte Kinder schwarzer Nacht. Lyrikanthologie ausgesuchter Liebes- und Freundschaftsgedichte von Sophie Albrecht (1757-1840). Brüssel: Bartleby.

Royer, Berit C.R. 1999. Sophie Albrecht (1757-1840) im Kreis der Schriftstellerinnen um 180o: eine literatur- und kulturwissenschaftliche Werk-Monographie. Dissertation, University of California at Davis. Ann Arbor, Michigan: Umi/ProQuest Dissertation Services.

Royer, Berit C.R (ed.). 2001. "Einführung" von der Herausgeberin. Vorwärts, vorwärts sehn' ich mich. Todes-Sehnsuchtsgedichte und der Tod der weiblich-kulturellen Rolle. Lyrikanthologie ausgesuchter Gedichte von Sophie Albrecht (1757-1840). Brüssel: Bartleby.

Royer, Berit C.R. 2006. 'Die Literatur der Schriftstellerin Sophie Albrecht (1757-1840) und ihrer Erfurter Kolleginnen als frühfeministischer und literaturgeschichtlicher Beitrag zur 'Dalbergzeit' (1772-1802)' in Michael Ludscheidt (ed.). Aufklärung in der 'Dalbergzeit', Literatur, Medien und Diskurse in Erfurt. Erfurt: Ulenspiegel, 333-357.

Royer, Berit C.R. 2015. 'Sophie Albrecht, ein künstlerisches Phänomen in Literatur und Theater des 18. Jahrhunderts - Gender, Rezeption und die Arbeitsgemeinschaft mit ihrem Ehemann' in Rüdiger Schütt (ed.). Verehrt. Verflucht. Vergessen. Leben und Werk von Sophie Albrecht und Johann Friedrich Ernst Albrecht. Hannover: Wehrhahn, 313-352.

Siebmacher, Johann. 1701/o5, und 1772. Wappen-Buch. Nürnberg: Raspisch.

Stoll, Karin. 1978. Christoph Martin Wieland:Journalistik und Kritik. Bonn: Bouvier.

Strieder, Friedrich Wilhelm. 1781. Grundlage zu einer hessischen Gelehrten und Schriftsteller Geschichte. 1.Bd. Göttingen: Barmeier.

Theaterkalender auf das Jahr 1786. H. A. O. Reichard (ed.). Gotha: Ettinger.

Thiel, Michael. 1970. Albrecht, Arzt, medizinischer Volksschriftsteller, politische Belletristik. Berlin: Dissertation.

Weckel, Ulrike. 1998. Zwischen Häuslichkeit und Öffentlichkeit. Die ersten deutschen Frauenzeitschriften im späten 18. Jahrhundert und ihr Publikum. Tübingen: Niemeyer. Wieland Briefwechsel. 2007. Bearbeitet von Siegfried Scheibe. BW 20.1. Berlin: Akad. Verlag.

Wittmann, Reinhard. 1991. Geschichte des deutschen Buchhandels. München: Beck. Zeitung für die elegante Welt. 1804. Intelligenzblatt der ZfdeW. 4. Jahrgang, No.39, 14, 6. September. Leipzig: Voß. 


\section{Index}

Aasen, Elisabeth $80 n 22$

Adamson, Sylvia 106

Adelgunde Gottsched, Luise 16o, 2o6, 2ogn 58

Adelung, Johann Christoph $\quad$ 230, $241 n 95$

Agorni, Mirella 203

Akslen Kvalbein, Laila $\quad 76 \mathrm{n} 10,82,86 \mathrm{n} 5 \mathrm{o}$, $87,92 n 78$

Albinoni, Tommaso 154

Albrecht, Carl Sigmund Wilhelm 227

Albrecht, Dorothea Johanna Charlotte 227

Albrecht, Johann Friedrich Ernst 226-233, 237, 239, 240, 242-246, 249

Albrecht, Sophie $\quad$ 11, 221-249

Alexander, G. 106

Almeloveen, Theodorus Janssonius van 129

Amerongen, Sara van 132

Amman, John Conrad 130, 133

Andersdotter Grytten, Ingeborg 78

Angelini, Tito $\quad$ 168n3

Anna Charlotta Amalia 136

Ardinghelli, Mariangela 174

Arvelius, F.G. $\quad$ 232n 52

Azevedo, Angela de 57

Baade, Coleen 66

Baldwin 204

Balzac, Honoré de $3^{2}$

Bangham, Mr. 110

Barbauld, Anna Letitia $\quad 195 \mathrm{n} 6$

Barbieri, Filippi 104

Baretti, Giuseppe $\quad$ 192, 209

Bassano, Aemilia see Lanyer, Aemilia

Bassano, Baptista 100

Batres, Alfonso de 47

Baumer, Dorothea Wilhelmine

Charlotte 224n12

Baumer, Johann Paul 222-23o

Baumer, Johann Wilhelm 224, 230

Baumer, Johanna Sophia Dorothea see Albrecht, Sophie

Baumer, Rebecca Johanna Maria

Christina 222, 224

Bawr, Alexandrine de $\quad 24-27,29,3$ o, 32

Beauvoir, Simone de $\quad 24 \mathrm{n} 23$
Bechtold, Friedrich $\quad 246$

Becket, Thomas 215

Behn, Aphra $\quad 73,78,86,87,94$

Beilin, Elaine 119

Bergalli Gozzi, Luisa $\quad 12,147-163,170$, 174, 208n55

Bergalli, Luisa see Bergalli Gozzi, Luisa

Bernal de Gatos, Juana 59

Bernal, Beatriz $\quad 59,60$

Bertie, Susan 100

Blair, Robert 113

Boccaccio 19, 36, 37

Boccage, Anne-Marie du $\quad 24,25 \mathrm{n} 34,26,29$, 3 o, 32-34, 15o, 162, 208n 55

Boccage, Monsieur du 33

Bondini, Pasquale 240

Borryeau, John 205

Boswell, James 196, 207, 215

Botelho de Carvalho, 53

Boudier de Villemert, Pierre-Joseph $\quad 16$

Bourbon, Charlotte 184

Boursault, Edmé 161

Boyle, John 199

Bradstreet, Anne $\quad 73,78,86,87,94$

Breton, Nicholas 102

Briquet, Fortunée 37

Brown, Dan 4

Browning, Elizabeth 83

Browning, Robert 83

Bürger, Elise $\quad 247 n 129$

Bürger, Gottfried August $\quad 242$

Cadell, Thomas 215

Calatayud, Francisco de 48

Caminer Turra, Elisabetta $\quad 147,148,151,161$, $163,170,186$

Caminer, Domenico 170

Capece, Giovanni $\quad 175 \mathrm{n} 18$

Capello, Bianca 209

Caravita, Nicolò $\quad$ 183n37, 184

Carey, Henry see Hunsdon, Lord

Caro, Ana $\quad 12,43,45-53,55 n 45,56,6$ o

Carriera, Rosalba 148

Carter, Elizabeth $\quad 195 \mathrm{n} 6$

Carton, Henri $\quad 16,20-30,32,33,36$ 
Carvajal, Mariana de $\quad$ 57-59

Casele, Maria van 133

Cassube, Christian $\quad 81 n 32,88 n 61,89$

Castillo Solórzano, Alonso de $\quad 47,53 n_{3} 8$

Catharine I 130

Cerda Téllez Xirón, María Rosa de la 66

Cerda, Don Ioseph Manrrique de la 66

Cervantes 41

Céu, Violante do 53

Championnette 185,188

Chandler, Mary 113

Charles I 130, 132-137

Charrière, Isabelle de 17, 18, 21nı1, 23n2o, 24, $35,36,37$

Châtelet, Gabrielle-Emilie du 24, 26, 29, 31, 32, 34, 208n55

Chemello, Adriana 159

Chiari, Pietro 147,148

Christina, Leonora 77

Chudleigh, Mary 10

Cirillo, Domenico $172 \mathrm{n} 10$

Cirillo, Giuseppe $172 \mathrm{n} 10$

Clarke, Norma 201

Clery, E.J. 3

Clifford, Anne $\quad$ 104, 105, 108, 119

Clifford, Margaret $\quad$ 104, 107

Coles, Kimberly 102

Collett, Camilla $\quad 73 \mathrm{n} 1$

Colonna, Vittoria 102, 106

Conte Collalto $\quad 153,159$

Cooke, Margaret see Russell, Margaret

Cornaro, Andrea 153

Cottin, Sophie $\quad 25,26,29,30,32$

Count of Salvatierra 47

Count-Duke of Olivares $\quad 46,48$

Countess of Bedford 104

Countess of Cumberland see Clifford, Margaret

Countess of Dorset see Clifford, Anne

Countess of Northumberland 204, 206

Countess of Pembroke 99, 104

Countess of Salvatierra 46, 47, 5on27

Crescimbeni, Gioavanni Mario $\quad$ 157, 158

Croce, Benedetto $\quad 168,169,171,172 n 10$, $176,187 \mathrm{n} 45$

Crowder 204

Cruz, Juana Inés de la 62

Cuoco, Vincenzo $\quad 167$

Curtoni Verza, Silvia 183

Czar Peter I 130
D'Audiguier, Vital $\quad$ 205, 206

D'Aulnoy, Marie C. 247

d'Este, Francisco 57

Dalberg, Antoinetten von $\quad 238$

Dalberg, Karl Theodor von $\quad 238$

Dass, Petter 74, 81n3o, 82, 83, 93

De Fonseca Pimentel Chaves, Clemente Henríquez 172

De Fonseca Pimentel, Eleonora $\quad$ 12, 167-189

De Liso, D. $\quad 182 n 34$

Decker, Georg Jacob $\quad 237$

Deffand, Mme du 21, 23

Delfico, Melchiorre 183

Deshoulières, Mme 21

Desplantes, F. 27-29, 31

Destouches, Philippe Néricault 161

Dijstelberge, Paul 136n41

DiPasquale, Theresa 120

Dodsley, James 206, 214

Dodsley, Robert $\quad$ 198, 204, 212, 215

Dolfin Tron, Caterina $\quad 162,174,175$

Dolfin, Caterina see Dolfin Tron, Caterina

Donne, John $\quad 85,88 \mathrm{n} 59,92$

Duc d'Orléans 30

Duchess of Newcastle 203, 204, 206

Duke of Newcastle 200, 202-204, 207n5o

Dupuis, Modeste 22

Durham 204

Earl of Southampton 101

Ellinghausen, Laurie 7

Elossidieta, Juan de 44, 45

Emperor Charles v 62

Empress Dona Maria 62

Engelbretsdatter, Dorothe 11, 73-94

Epolnifenora, Olcesamante see De Fonseca Pimentel, Eleonora

Erxleben, Dorothea 225

Esperetusa, Altidora see De Fonseca Pimentel, Eleonora

Ettenhuber, Katrin 106

Evers, Barbara $\quad$ 236, 247n129

Ezell, Margaret $\quad$ 6, 9, 98

Ferdinand IV $\quad 168,183,172,175,182,184$

Ferreira de Lacerda, Bernarda 60

Filangieri, Gaetano $\quad$ 172n10, 183

Finch, Isabella $196,200,204,210$

Fleeman, John David 199

Fletcher, Giles 102 
Fleurs, Philiberte de 22

Fleury, Claude $\quad 150,160$

Fonseca, Antonio 168n3

Fonte, Moderata 159

Forman, Simon $\quad$ 100, 101, 103

Fortis, Alberto $\quad 180,183,186$

Foscolo, Ugo 169, 170

Franco, Veronica 102

Frederick I of Sweden 132, 133, 138, 139

Freitag, F.V. $\quad 241$

Fusco, Eleonora $172 \mathrm{n} 10$

Fyodorovna, Maria 180

Gad, Cille 77n14

Gagliardi, Donatella 59

Galanti, Giuseppe Maria 186

Gallagher, Catherine $\quad$ 197, 211-213

Garrick, David 192, 196, 199, 208n55

Geisler, Adam 225

Geldorp, Jan Gerritsz 132, 133

Genles, Félicité de $\quad 247 \mathrm{n} 129$

Genlis, Stéphanie de $\quad 25,26,29,30,32,37$

Genovesi, Antonio 172

Geoffrin, Marie-Thérèse $\quad$ 25, 26, 29, 30, 32

Gersdorf, Wilhelmine von 244

Giannone, Pietro 172, 183n37

Gilbert-Santamaría, Donald $67 n 81$

Godet, Philippe 21n11, 35n74, 36

Goethe, Johann Wolfgang von 233n55, 239

Goldoni, Carlo $\quad 147,149,151,152,156$, 157,162

Goldsmith, Oliver 199

Gorani, Giuseppe $\quad$ 183n36

Gottsched, Johann Christoph 2o9n 58

Gottsched, Luise Adelgunde 16o, 2o6, 2ogn 58

Gournay, Marie de 25, 26, 29, 31-33

Gozzi, Carlo $\quad$ 147-150, 163

Gozzi, Francesco $\quad$ 150, 16o-162

Gozzi, Gasparo $\quad 149,151,157,159-161$

Gozzi, Iacopo Antonio $\quad$ 149, 155

Graffigny, Françoise de 22

Grainger, James 205

Gravina, Gian Vicenzo $15^{8}$

Graziosi, Elisabetta 65

Griffin, Dustin $\quad 5,6,98$

Griffith, Elizabeth $195 \mathrm{n} 6$

Grindal, Gracia 94

Grove, Leslie Ann 93n84, 94

Großmann, Gustav Friedrich Wilhelm 240
Guidi, Carlo Allesandro 177

Gyllenstierna, Maria Gustava 77

Hahn, Ferdinand von $\quad$ 242n96, 246

Hardenbeck, Ambrosius 77

Harmes, Georg $\quad$ 133n31, 136, 138, 141, 142

Hassebart, Jacob 85

Hauge, Hans Nielsen 93n8o

Hauger, Torill Thorstad $77 \mathrm{n} 14$

Haywood, Eliza $\quad 207 \mathbf{n}_{52}$

Herder, Johann Gottfried 232

Himmel, Friedrich Heinrich 244

Hobby, Elaine 2

Hofmo, Gunvor 73n1

Holberg, Ludvig $\quad 74,83$

Hoofman, Elisabeth $\quad 12,124,126,128-142$

Hoofman, Joost 132

Hoogenboom, Hilde $\quad$ 16n1, 19

Hudson, John 103

Hunsdon, Henry see Hunsdon, Lord

Hunsdon, Lord $\quad 98,101,103$

Hunter, William 211

Ibsen, Henrik 83

Inchbald, Elizabeth 201

Infanta Maria $\quad 61,62$

Infelise, Mario $\quad 151,15^{2}, 162$

Jacquinet, Paul 27-30, 32

James, E.L. 4

Jerocades, Antonio $173 n 14$

Johnson, Margaret 101

Johnson, Samuel 192, 194, 196-200, 202,

$$
\text { 204-206 }
$$

Johnston 204

Kaae, Joachim $\quad 84,85$

Kamiensky, Friedrike von $\quad 236$

Katherine of Suffolk 99

Kauffmann, Angelika 195n6

Kelly, Hugh 208

Kernan, Alvin 6

Kick, Johann Joducus 224n12

Kiddell, John 109

King Christian IV 77

King Christian V 81, 91

King Frederic IV $\quad 81,91$

King Frederick III $\quad 126$

King James I 99

King Philip II $\quad 60$ 
King, Kathryn 9

Kingo, Thomas $74,75,81,87,93 n 8$ o

Kolbe, Regina Elisabeth $\quad 228 \mathrm{n} 26$

Koolaart, Hester $\quad$ 130, 131, 133, 142

Koolaart, Petronella $13 \circ, 131,136,138$, 141, 143n63

Koolaart, Pieter $\quad 126,130,131,134,135,138,140$

Koolaart-Hoofman, Elisabeth see Hoofman, Elisabeth

Kops, Willem 129, 132-136

Kraayestein, Margareta $\quad 133,140$

Kraayestein, Maria $\quad$ 140, 141

L'Héritier de Villandon, Marie J. 247

La Fayette, Madame de $\quad 78$

La Harpe 22

La Porte, Joseph de 16, 19, 20, 27-30, $3^{2-}-34,36 n 76$

La Roche, Sophie von 224n12, 233, 236, 242, 248n135

Labé, Louise $\quad 21,22,25,26,29,31-33$

Lafayette, Mme de 22

Landstad, M.B. 93

Lanyer, Aemilia $\quad$ 12, 97-108, 119, 120

Lanyer, Alphonso 101, 103

Larnac, Jean $\quad 20,28,29,32,35,36$

Lasocki, David 103

Lasson, Anna Margrethe $\quad 84,86$

Leapor, Mary $\quad 8,113,115,116$

Lengefeld, Charlotte von $232 n 48$

Lennox, Alexander 192, 194, 196, 207n, 211, 212

Lennox, George Luis 215

Lennox, Harriot Hollis 211, 215

Lewalski, Barbara 101, 119

Leyva, Ana de $55 \mathrm{n} 45,57,6$ o

Linley, Elizabeth $195 \mathrm{n} 6$

Liston, Robert $\quad 24 \mathrm{n} 22$

Lock, Ann 103

Longfellow, Erica $\quad$ 102,103

López de León, Caterina 172

López, Antonio 172

López, Michele 176, 177

Loughlin, Marie H. 119

Louis XVI 185

Luna Enríquez, Leonor de $\quad 46$

Macaulay, Catherine $\quad$ 195n6

Malay, Jessica 119
Malespini, Celio 209

Manley, Delarivier $\quad$ 207n52

Manteuffel, Karl Reinhold 227, 233

Manuzio, Aldo $\quad 151$

Marchante, León 64

Marcos, Mercedes $\quad 65,66 n 78$

Maria Carolina $\quad 168,172,175,180,181,183-185$

Marie Antoinette $\quad 185$

Medebach, Girolamo $15^{2}$

Mendoça y Piçaña, Jorge de $\quad 46$

Metastasio, Pietro $169,173,175,18$ o

Miani, Marco 155

Millar, Andrew $\quad$ 201, 202, 204, 206

Minichini, Sergio 172

Molière 149, 151, 157

Møller, Peder 75

Mongellaz, Fanny 37

Montagu, Elizabeth 195

Montagu, Mary Wortley $\quad 113,114,196$

Montaigne, Michel de 25, 31

Montenglaut, Henriette von 249, 250

Montferrand, Alfred de 27-29

More, Hannah $195 \mathrm{n} 6$

Morell, Juliana 62

Moskwa, A.B. 229

Mother Bernardina de Jesús $\quad 64$

Müller, Heinrich 75

Munter 182

Navarre, Marguerite de 21

Nicholl 110

Nonacrina, Dorina see Dolfin Tron, Caterina

Ofefice, A. 168n3

Opitz, Christian Wilhelm 244

Oratius 182

Ottoboni, Pietro 159

Partenide, Irminda see Bergalli Gozzi, Luisa

Pelegrin, Christóbal 59

Peraita Huerta, Carmen $\quad 57 \mathrm{n}_{51}$

Pérez de Montalbán, Juan 53, 56

Perrault, Charles 247

Petrarch 177

Petrovich, Pavel 180

Pieretti, Marie-Pascale $\quad$ 200, 201, 208n55

Pimentel, Eleonora see De Fonseca Pimentel, Eleonora 
Pinelo, Valentina 64

Pisa, Francisco de 61

Pizan, Christine de $\quad$ 19, 24, 26, 30-32, 34, 37,102

Plebani, Tiziana 159

Pola Argentaria 53

Pollard, A.W. 99

Pope Paul III 61

Pötting, Eusebius von 58

Poulson, Sarah J. 94

Pouthier, P. 27-29, 31

Prescott, Sarah 9, 114

Prevost, Antoine-François 201

Prince Henry 99

Prince of Wales 204, 207

Princess Amelia (Emily) $\quad 196$

Princess Caroline 196

Princess Elizabeth 104

Princess of Palestrina 154

Prior, Roger 103

Propiac, Catherine-Joseph-Ferdinand

Girard de $\quad 27-29,34$

Queen Anne 104

Queen Caroline 118

Queen Catherine 61

Queen Charlotta Amalia 91

Queen Charlotte 200, 204

Racine, Jean $\quad$ 149, 152, 155, 208n 55

Rambouillet, Mme de $\quad 21-23$

Ramsay Lennox, Charlotte $\quad 11,192-215$

Ramsay, Charlotte see Ramsay Lennox, Charlotte

Redgrave, G.R. 99

Reenberg, Tøger 86

Reinecke, Friedrich 237

Reyes, Juan Antonio de los 65

Ribera, Pietro Paolo 61

Riccoboni, Antoine-François $\quad 24 n 22$

Riccoboni, Marie-Jeanne $\quad 23-26,29$, 30, $3^{2-} 34$

Richardson, Samuel $\quad$ 192, 196, 198, 199, 204

Richelieu 25, 31-33

Rioja, Francisco de 48

Rodríguez, Gregorio $\quad 5^{8}$

Rogers, John 105

Rogert, Hugh 110

Roland, Mme 21
Rolfsen, Nordahl 92

Rose, Mark 6

Rowse, A.L. $\quad 100,103$

Russell, Margaret 119

Sà Pereira, Josè de $\quad$ 172, 173

Salfi, Francesco 187

Salignac de la Mothe Fénelon, François de 208

Samuel, Richard $\quad$ 195n6

San Félix, Marcela de 64

Sánchez, Vicente 64

Sand, George 27

Sandel, Cora $\quad 73 \mathrm{n} 1$

Sannazaro, Jacopo 106

Santa Gertrudis, María de 65

Santa Teresa, Francisca de $\quad 65,66$

Santísima Trinidad, Manuela de la $\quad 65,67 \mathrm{n} 81$

Sanz, Gabriel 66

Sappho 53, 239

Saunders, J.W. $\quad 97$

Schellenberg, Betty A. 213

Schiattarella, F. 184

Schiller, Friedrich $\quad 221,231,232,240,242$

Schønau, Fr. Chr. 78

Schott, Andreas 61

Schürer, Norbert $\quad$ 199, 204n37, 215

Scudéry 22

Seager, Jane 104

Sévigné, Mme de 21

Seward, Anna 9

Sforza, Antonio $\quad$ 149, 159

Shakespeare, William $\quad 98-101,103,104,107$, 204, 226n19, 244, 245

Sharpe, Gregory 205

Shuger, Debora 106

Sidney Herbert, Mary 103

Sigea, Angela 61

Sigea, Luisa $\quad 12,40,60-62$

Simmes, Valentine 99

Singer Rowe, Elizabeth 10

Skaar, J.N. 87

Skram, Amalie $\quad 74 \mathrm{n} 1$

Smith, Charlotte 201

Smith, Helen $\quad 119,125$

Sophie Gutermann see La Roche, Sophie von

Soranzo, Giacomo 159

Soriana, Fabiana 65 


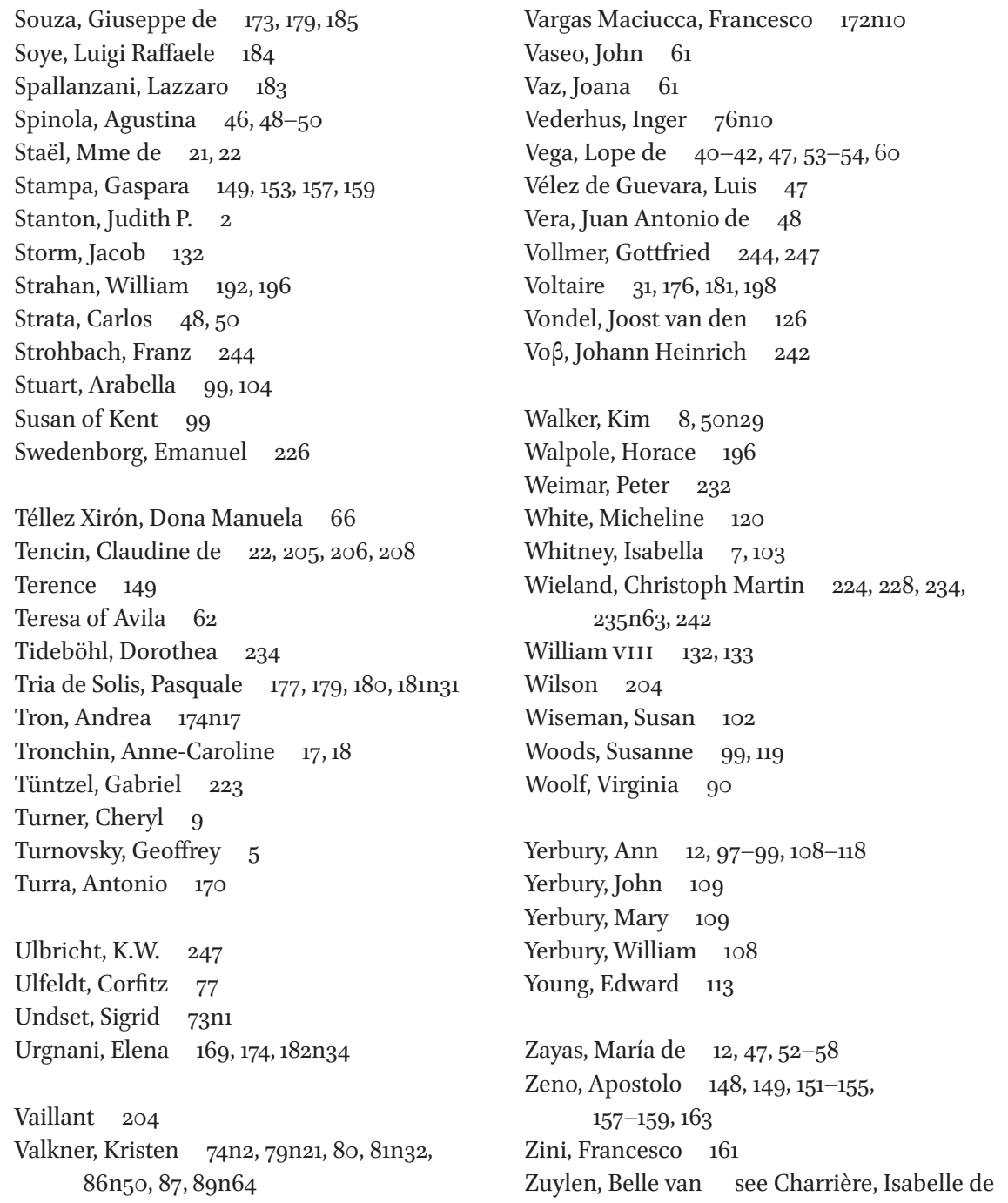

